Historic, Archive Document

Do not assume content reflects current scientific knowledge, policies, or practices. 

$\operatorname{Zin} 62.29$

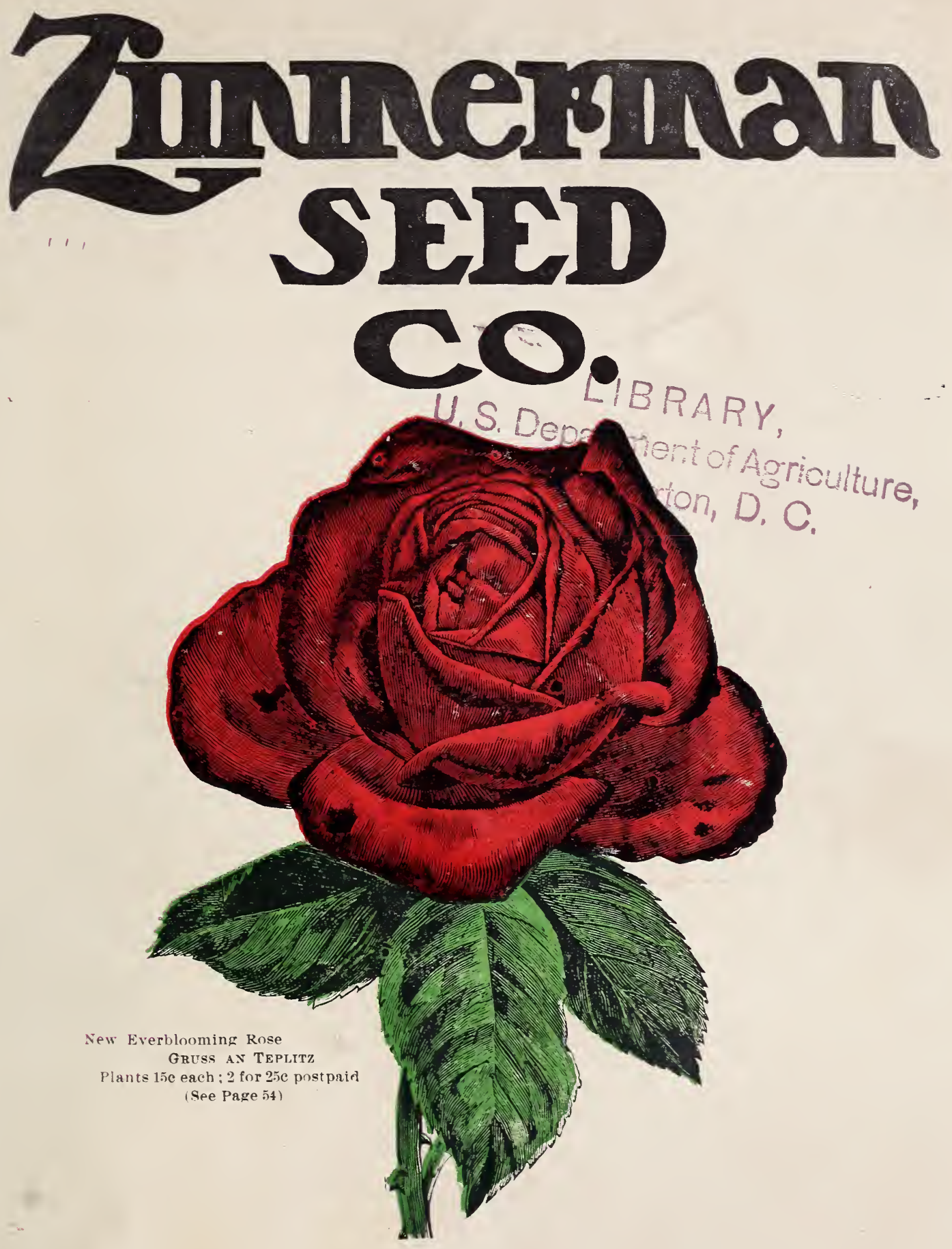

Topeka. Kansas.

1907 


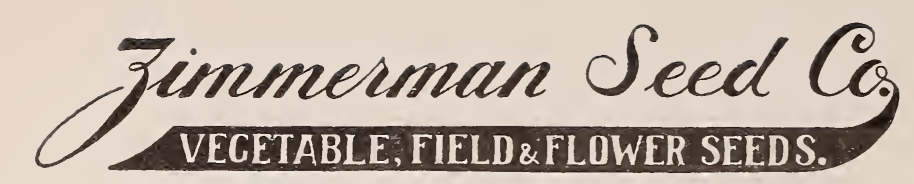

Office 625 Quiricy st.

\section{Topeka, Kan., January 1907.}

\section{To Our Patrons and Friends:}

In presenting our 1907 Catalogue, we wish to express our thanks for the valued patronage of the past, and also our appreciation of the nany kind letters we have received.

Our square way of doing business; our DOLLAR'S WORTH FOR A DOLLAR plan, and the fact we have ONLY THE BEST SEED, thoroughly tested, is winning for us the approval and trade of the honest, substantial gardeners, farmers and planters of this country. You will find no over-drawn descriptions in this book--no loud and fancy-colored pictures of impossible vegetables, flowers, etc--no '6windy" stories. Just PLAIN, HONEST FACTS about HONEST SEEDS sold at an HONEST PRICE. Dont you like this way of doing business? If so, send US your order this year. You will like our methods and you will be pleased with our seed.

We again desire to thank those who have patronized us in the past and trust to be favored with their order again this season, and that many new friends may be added to our steady growing list. We promise careful and prompt attention to your orders.

Very truly yours, J. S. ZIMMERMAN, Manager.

\section{READ THE FOLLOWING CAREFULLY:}

HOW TO ORDER Be sure to sign your name, Post-office, County and State and, if possible, use one of our order sheets and envelopes. Cash must accompany all orders, and money should he sent by Post-office r,rder, Bank draft, Express order or Registered letter; sniall amcunts will he accepleu in justant stamps, pr uviding you cannot send anything else. Do not send money loose in a letter without registering. it is not safe and, if lost, we are not responsible for it. Silver coin should be sewed or pasted in cloth or pasteboard to prevent its breaking through the envelope.

FREE BY MAIL We pay the postage on all orders sent by mail, at the prices named in the catalog inis brings them to the door of our customers, without trouble or expense.

EXPRESS AND IREIGHT On articles ordered sent by Express or Freight, the transportation charges must be paid by the customer, on receipt of the goods; when ordering always say whether good:shall be sent by Express or Freight and give plain shipping directions. Seeds are carried by express companies at $20 \%$ less than merchandise. When seeds catalogued at postpaid prices are sent with an express or freight shipment, we deduct the postage, which will reduce the cost of ; packets $1 \mathrm{c} ;$ oz $1 \mathrm{c} ; 1 / 2 \mathrm{lb} 4 \mathrm{c} ; 1 \mathrm{~b} 8 \mathrm{c}$; pts $8 \mathrm{c}$; qts $15 \mathrm{c}$.

OUR GUARANTEE We guarantee that all seeds and other goods sent out by us shall reach the purchaser saie and in good condition; be fresh and of good quality and to grow, if properly planted and, if such should not prove the case, will refill the order free of charge, providing sufficient proof is given within a reasonable tims. We cannot guarantee crops and will not be held responsible for them or for any liability other than above stated.

CULTURAL BOOK. This book, giving plain directions for the proper cultivation of garden, field and flower seeds, is sent FREE with an order amounting to one dollar or more, providing you ask for it. This book should be in every home. 
Read what our customers say in the letters below. We don't print a lot of so-called "novelties" on pink or yellow paper and sell them at high prices. We don't sell 50 certs worth of seed for $\$ 1.00$ and give a 25 cent presen as a bait. But we DO sell one dollars worth of seed for one dollar, and it's all the very best-the kind it pays to plant. Try us this year-we'll treat you right.

Zimmerman Seed Co

Roosevelt, Okla., Feb. 5, 1906. We planted your seed last year and were well pleased with them. Yours truly, Mrs. Clark Williams.

Zimmerman Seed Co.

Woodlawn, Ala., Feb. 15, 1906. I liked your seed so well last year, you will get my full order this year. The Combination Corn was simply fine. Very respectfully, Mrs. J. C. McPherson.

Zimmerman Seed Co.

Bonneauville, Pa., March 19, 1906.

Your seeds are the finest I ever planted. I never saw such nice lettuce as I got last spring and the peas could not be excelled.

Zimmerman Seed Co.

Miami, Texas, Jan., 1906.

If I have made the wrong selections in this order, please substitute, as I can trust you to do what is right, and I know your judgment is good.
Yours very truly,
W. M. Durham.

Zimmerman Seed Co.

Owl, Ind. Ter., April 16, 1906. I have bought your seeds for the past four years and find them O. K. Yours truly,

Mullhall, Okla., Nov. 2, 1905.

Zimmerman Seed Co.

talogue. I tried your seeds las Please send me your catalogue. I tried
year and was well pleased. Yours truly.

Herman Schulze.

Roosevelt, Okla., June 7, 1906.

Zimmerman Seed Co.

The seeds I got of you in the spring grew well. Respectfully, Mrs. J. Thompson.

Concordia, Kan., June 26, 1906.

Zimmerman Seed Co.

All the seeds I purchased from you this last spring did well, and I am more than pleased with them. With best wishes for your success, I am, Yours respectfully,

W. H. Remy.

Rankin, Okla., July 21, 1906.

Zimmerman seed Co.

I got two bushels alfalfa seed from you in the spring and it did fine. I want to sow more in September. Yours truly, J. C. Crawford.

Elizabeth, Ky., March 30, 1906.

Zimmerman Seed Co.

Having had wonderful success with your seed last year, herewith send an order for this season. order for this season. William Jones.
Yours truly,

Mayfield, Kan., Jan. 7, 1906.

Zimmerman Seed Co.

Mayfield, Kan., Jan. 7, 1906.

I was well pleased with the seeds I bought of you last year.

Yours truly,

Chas. W. Banks.

Zimmerman Seed Co.

Winfield, Texas, Jan. 24, 1906. I used your seed last year with the best of results.
Yours very truly, Mrs. H. S. Floyd.

Zimmerman Seed Co.

Bendena, Kan., Oct. 9, 1906.

Please send the name of a commission man who handles cabbage. The seed I received from you did fine. I received from you did fine.
oblige,
Zimmerman Seed Co.

Norfield, Miss., Nov. 23, 1906.

I have found your seed is the best I ever tried; have been using no other for two or three years. Send new 1907 Catalogue. Yours customer, Minnie Smith.

Zimmerman Seed Co.

Kinzers, Pa., March 8, 1906.

Received my seeds and am very much pleased with them. I thank you for your kindness.

$$
\begin{gathered}
\text { Very truly yours, } \\
\text { Henry } \mathrm{K} \text {. Dosch. }
\end{gathered}
$$

Zimmerman Seed Co.

Wheatly, Ark., March 2, 1906

I have nice flowers and a nice garden every year from your seeds. I like them and will continue to use them in the future. Wishing you success, Respectfully,

Mrs. Lethy Lawson.

Zimmerman Seed Co.

Midland, Ark., Feb. 27, 1906.

Just received the seed from you and am well pleased. The fullest packets I ever saw. Yours respectfully, J. W. Cowdrey.

Zimmerman seed Co.

Copan, Ind. Ter., March 20, 1906

I received my seed all right and am well pleased. Mrs. A. Hooker

Caddo Mills, Texas, Feb. 13, 1906.

Zimmerman Seed Co.

I am glad to hand you my order again. I have been using your seeds ever since you were first established, and you have the best I ever tried. I have induced some of my neighbors to order from you this year and I know they will order from you in the future. Yours,

J. A. Ross.

Zimmerman Seed Co

Berwyn, Ind. Ter., Feb. 27, 1906.

My order placed several days ago, came in alright, and I am well pleased. Henceforth you may put me down as a regular customer. Very truly,

(Rev.) W. R. Brock.

Zimmerman Seed Co.

Flagler Station, Colo., Feb. 5, 1906.

The seeds I bought of you last year gave such good satisfaction I will be pleased to order from you and speak a good word for your house whenever opoprtunity offers. Respectfully,
Henry E. May.

Zimmerman Seed Co.

Osawatomie, Kan., April 12, 1906.

I had some lettuce seed from you last year and it was fine; the best I ever saw. Will order from you this year. Yours.

A. D. Dickerson.

Zimmerman Seed Co

Clear Spring, Md., March 20, 1906.

I had a few packets from you last year and they were fine, especially the radishes and beets. Enclosed find my order. Yours respectfully, Mrs. Joseph Hastings.

Zimmerman Seed Co.

Cumby, Texas, Jan. 19, 1906.

Don't fail to send me your new catalogue as I planted your seed last year and had the best garden I ever had and want to again this year. Very respectfully,

Mrs. W. M. Pickens. 


\section{ZIMMERMAN'S}

\section{Complete Garden Collections.}

We have prepared the following collections very carefully and believe they cover the requirements of the average private garden. They are from our regulcr High Grade stock, FRESH AND PURE, and you will find them great money savers, for we have fixed the price very low. READ THEM CAREFULLY.

\section{ONE DOLLAR PACKET COLLECTION. We send you 39 full size packets, postage paid for only $\$ 1.00$.}

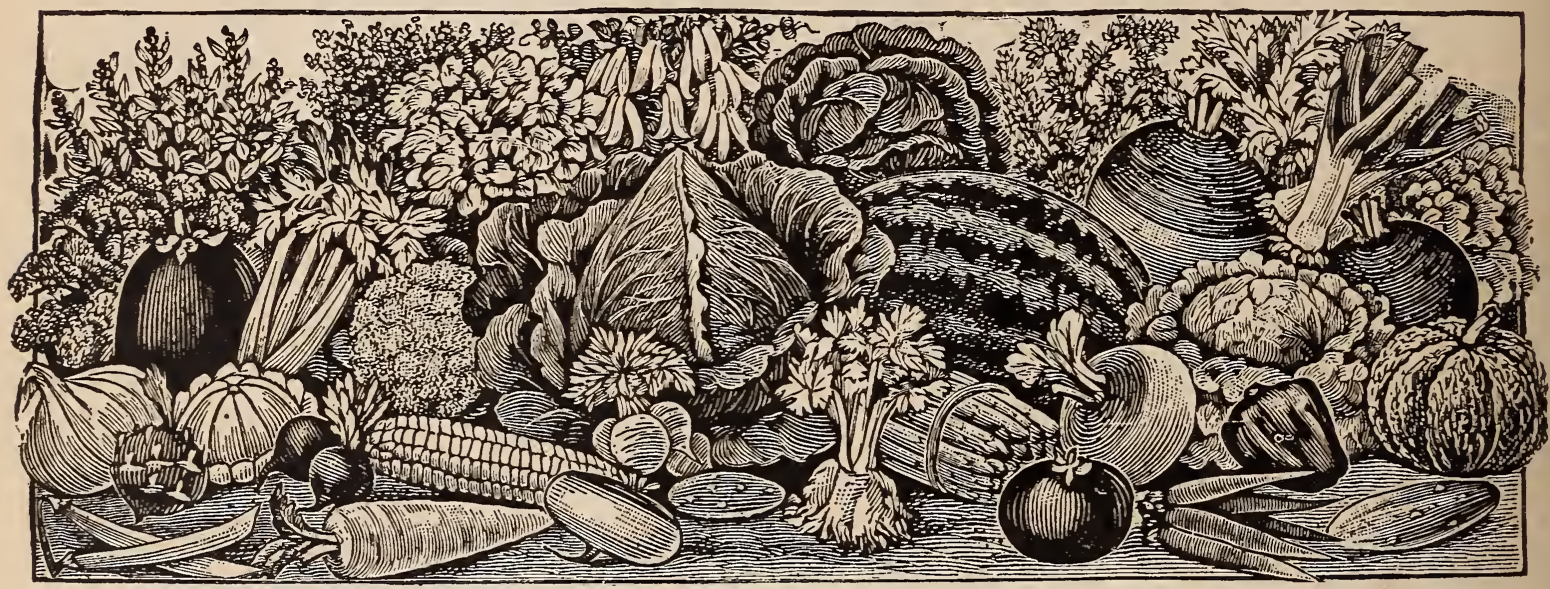

Asparagus-Palmetto. Beans-Rust Proof Was. Red Valentine. Bush Lima. Beet-Egyptian. Lentz. Cabbage-Extra Early. Late Variety. Carrot-Danver's Half Long, Celery-White Plume. Sweet Corn-Early Mammoth. Cucumber-Zimmerman's Earliest. Lettuce--Zimmerman's Earliest. Improved Hanson. Musk Melon-Montreal Market. Watermelon-Black Diamond. Kentucky Won der. Onion--Awetralian Brown. Yellow Globe Danvers. Peas -Nott's Excelsior. Bliss' Everbearing. Parsnip-Hollow Crown Sugar. Pepper-Ruby King. Cayenne. PumpkinThanksgiving Ple. Radish-New Lightning. Long Scarlet Short Top. Spinach-New Long StandIng. Salsify-Mammoth Sandwich Island. Squash-Hubbard. Tomato-Paragon, Gold Dust. Turnip-Early White Milan. Yellow Purple Top. In addition. you may select 25̃c torth, in packets, FREE. All postpaid for \$1.oo.

\section{\$1.00 Box. HOME GARDEN. \$1.00 Box.}

Regular value 2.20. For only \$1.00 we send this collection postpaid to any address.

Beans--- $1 / 2$ pint Early Red Valentlne. $1 / 2$ pint Rust Proof Wax. Pkt Bush Lima. Beet---Pkt Blood Turnip. Cabbage--Pkt Extra Early. Pkt Late. Carrot---Pkt Ox-Heart. Sweet Corn---1/2 pint Evergreen. Cucumber--Pkt Long Green, Egg Plant---Pkt Large Purple. Iettuce---Pkt Zimmerman's Earliest. Pkt Improved Hanson. Musk Melon---Pkt Eariy Hackensack. Watermelon--Pkt Peerless, Onion---Pkt Brown Australian. Parsnip---Pkt Hollow Crown Sugar. Peas---1/2 pint Everbearing. Pkt Two Weeks Early. Radish--Pkt French Breakfast. Pkt White Lady Finger. Squash---Pkt Summer Variety. Tomato---Pkt Gold Dust (Red.) Turnip--Pkt White Flat Dutch.

In addition, you mav select $\mathbf{2 5} \mathbf{c}$ worth in packets FREE, making the value of this collection $\$ 2.20$, which we are offcring, postpaid, for ONLY $\$ 1.00$.

\section{$\$ 2.00$ Box. THE FAMEY GARDEN. $\$ 2.00$ Box.}

This Collection continues to be very popular and will supply an average family with choice vegetables the entire season. Is sent by express, uot prepaid, for ONLY $\$ 2.00$. Our seeds have a rate of 20 per cent less than merchandise, making the cost light.

Boans---Pint Rust Pr oof Wax. Pint Red Valentine. $\quad$ / $/ 2$ pint Bush Lima.

Beet--Oz Blood Turnip.

Cabbage---Pkt Early. Pkt Late. Carrot--.Pkt Half Long Danvers.

Sweet Corn---1/2 pint Early Mammoth. Pint Stowell's Evergreen . Cucumber-Plit Zimmerman's Earliest. Pkt Long Green. Egg Plant--Pkt Large Purple. Leek-Pkt. I Lettuce--Zimmerman's Earliest. Pkt Improved Hanson, MIsk Melon---Early Large. Pkt Montreal Market. Watermelon---Oz Black Diamond. Oz Kolbs Gem. Onion---Pkt Yellow Danvers. Pkt Brown Australian. Parsley---Pkt. Parsni p--Pkt Hollow Crown Sugar. Peas---Pint Nott's Excelsior. Pint Everbearing. 1/2 pint Mammoth. Pepper--Pkt Ruby King. Pkt Cayenne. Pumpkin-Pkt Sugar. Radish---Oz New Lightning. Pkt White Icicle. Pkt Long Scarlet Short Top. Salsify-Pkt. Spinach---Pkt. Squash---Pkt Summer. Pkt Hubbard. Tomato--Pkt Paragon. Pkt Western Giant. Turnip -Pkt White Milan.

In addition, you may select $50 \mathrm{c}$ worth in packets FREE, making this a grand collection. 


\section{Zimmerman's}

\section{Tested}
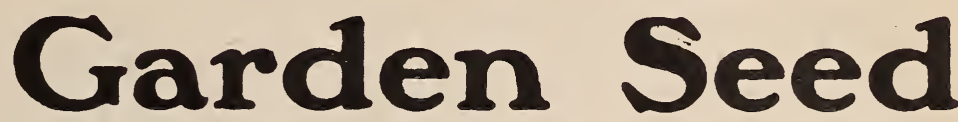

\section{FOR 1907.} $\mathrm{N}$ the following list will be found the leading STANDARD and RELiABLI varieties. We have some NEW
varieties, which we offer at reasonable prices. We dont deal in Fancy Pages filled with so-called "Novelties." All OUR seed is tested. "None better at a higher price ; none as good at a lower price"

DTCTOT G GREN GLOBE-The favorite from seed. Scales pale green shading to violet at the base A 1 I L thick and fleshy. Esteemed for its large flower buds, Pkt 5c.; oz 35c.; $1 / 41 \mathrm{lb} \$ 1.00$, postpard.

JERUSALEM-Raised from tubers like potatoes. Fine for stock and will resist the coldest weather. Plant in early spring. One of the best hog feeds raised. Per lb 15c., postpaid. By express or freight, pk 40c.; $1 / 2$ bu 65 c.; bu $\$ 1.25$.

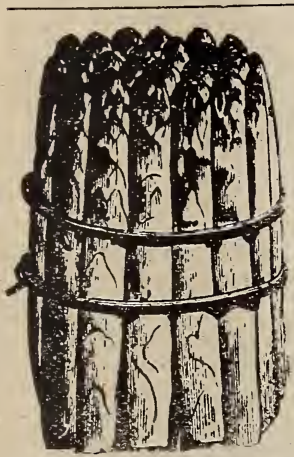

\section{ASPARAGUS.}

PALM ETT0-The earliest, finest and best variety. Strong and vigorous in growth: very rich and tender when cooked. Pkt 5c.: oz 8c.; $1 / 4 \mathrm{lb} 20 \mathrm{c}$; $1 / 2 / 2 \mathrm{lb} 30 \mathrm{c}$.: lb 50c, postpaid.

CGNOVER'S COLLOSSAL-An extra large, quick growing variety : stalks frequently measure over one inch in diameter. Pkt 5c.: oz Sc.; $1 / 4$ lb 15c., 1/2 lb 25c.; lb 40c, postpaid.

\section{ASPARAGUS ROOTS.}

Strong roots of the above varieties: $25 \mathrm{c}$ per dozen. $\$ 1.25$ per 100 by mail postpaid. By express 1 isr old roots, 250 for $\$ 1.40 ; 500$ for $\$ 2.50 ; 1.000$ for $\$ 4.75$. 2-yr-old roots, 250 for $\$ 1.60 ; 500$ for $\$ 3.00 ; 1,000 \$ 5.00$ We do not advise shipping Asparagus Roots by freight, as they are then liable to be delayed.

Our Cultural Booklet tells just how to raise Fine Asparagus. Its FREE with a $\$ 1.00 \mathrm{Ve}-$ getable Seed Order.

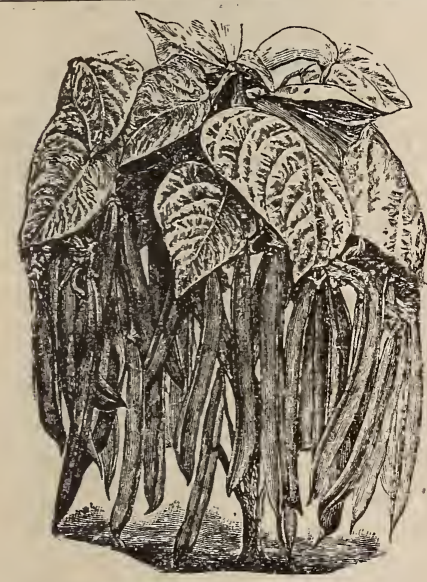

STRINGLESS GREEN POD.

\section{BEANS-Dwarf Green Pod}

STRINGLESS GREEN POD-Combines rare qualities possessed by no other. It is entirely stringless, unusually hardy, very early and productive. Pods are ready for market some two neeks earlier than other beans. Pods are a rich green, round, meaty straight, tender and of fine flavor. It is the only absolutely stringless green pod grown and is of the highest value. not only to the market gardener, but the home garden as well. Pkt 5c., $1 / 2$ pt 15c., pt 25c., qt 40c., postpaid. By express or freight, qt 25c., 4 qt, $80 \mathrm{c}$. peck $\$ 1.50$.

\begin{abstract}
STRINGLESS RED VALENTINE--Resembles the old Valen tine but pods ale largea. They are very early, of fine quality and generally stringless. Pkt 5c. 1/2 pt $15 \mathrm{c}$. pt $25 \mathrm{c}$, stringless. Pkt 5c., $1 / 2 \mathrm{pt} 15 \mathrm{c} ., \mathrm{pt} 25 \mathrm{c}$,
qt $40 \mathrm{c}$, postpaid. By express or fr't, qt $25 \mathrm{c}$., 4 q ts $80 \mathrm{c}$., peck $\$ 1.50$.
\end{abstract}

IMP. EARLY RED VALENTINE-A great favorite. Is tender, extra early and very productive. We have an extra choice stock of this fine bean at a low price. Pkt 5c., $1 / 2$ pt $10^{\circ}$. pt $20 \mathrm{c}$, qt $30 \mathrm{c}$. postpaid. By express or freight, qt $15 \mathrm{c} ., 4$ q ts $55 \mathrm{c}$. peck $\$ 1.00$.

ROUND YELLOW SIX WEEKS-The earliest of beans and is superior to the old Long Yeliow Six Weeks, being round, morc meaty and of excellent flavor. Pkt 5c. $1 / 2$ pt 12c., pt 20c., qt 35c., postpaid. By express or freight, $q$, $20 \mathrm{c}, 4$ q ts $70 \mathrm{c}$., pk $\$ 1.30$.

WHITE KIDNEY -The old favorite "succotash" bean. With new sweet corn, this bean makes a delicious dish. Pkt 5c.; 1/2 pt 12c. pt 20c. qt 35c. postpaid.

WHITE MARROWFAT-A very large oval bean. Shells green or dry. Pkt 5c. pt 20c, qt 35c., postpaid. By express or fr't, qt 20c. 4 qts $70 \mathrm{c}$. pk $\$ 1.30$.

D. Remember we pay the postage on pints and quarts. You will fine our prices low, considering the High Quality of our seed BEANS Continued on Next Page.

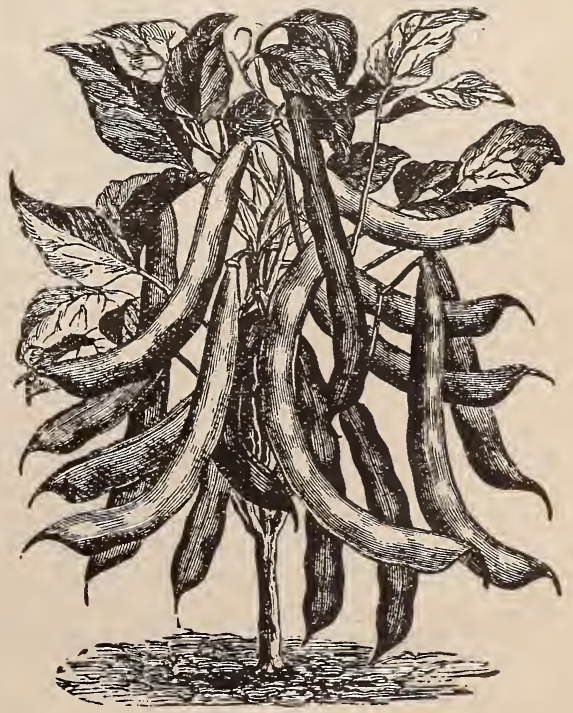

EARLY RED VALENTINE. 


\section{BEANSœDwarf Wax Podded.}

ahort this season. We have a nice stock, however, all fresh and bright and expect to be able to fill all orders, but we hope you will order early.

\section{Currio's Rust Proor \\ - Golden Wax.}

A decided improvement over the old Golden Wax. It produces an enormous quantity of beautiful, long, bright pods; clear, transparent color and of delicious flavor. Our iests have shown it to be entirely rust proof. It is especially valuable on account of its heavy bearing qualities. The stock we offer will be found to be the highest possible quality. This is one of the earliest, finest and most prolific of Wax Beans; is of high, rich fiavor and fine for market and home garden. Plkt 5c,: 1/2 pt 12c.; pt 20c. : qt 35c., postpaid. By express or freight, qt 20c. ; 4 qts $75 c .:$ peck $\$ 1.40$.

IMPROVED GOLDEN WAX---Not the equal of Currie's Rust Proof, but still a favorite with many. Same price is the Rust Proof.

Please remember we pay the postage on pints and quarts.

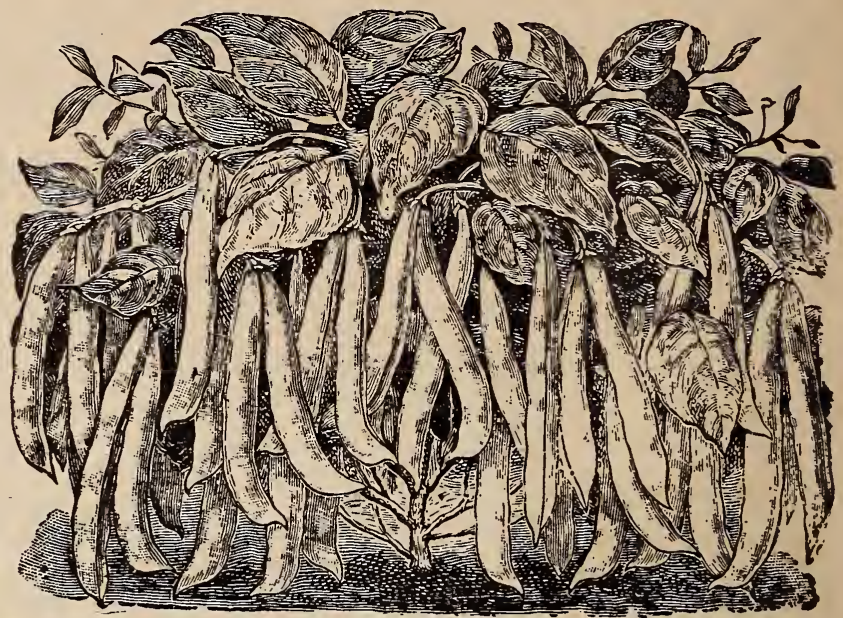

CURRIE'S RUST PROOF WAX.

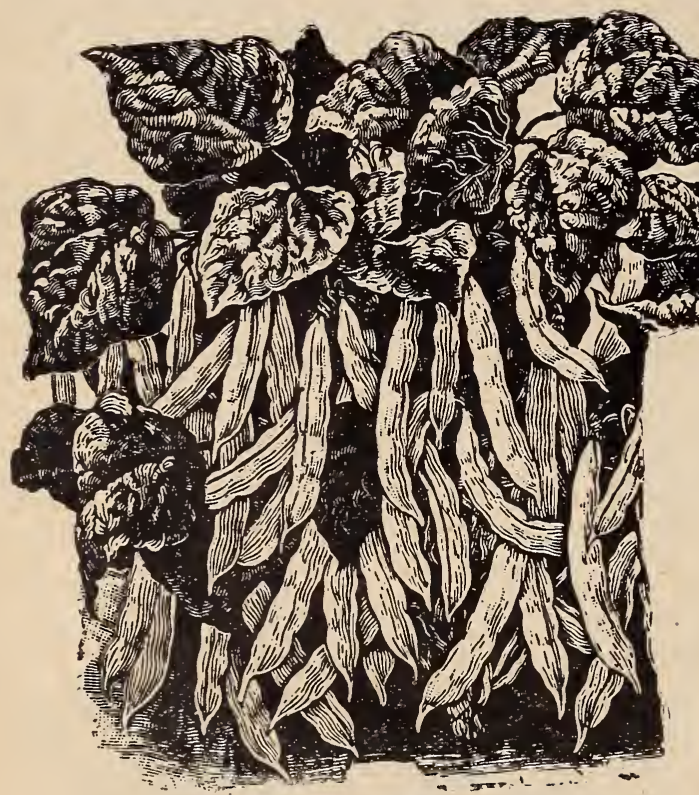

ZIMMERMAN'S GERMAN WAX.

Wardwell's Itidney Wax.

This is one of the best known wax beans and is a favorite everywhere, especially with Market Gardeners. Is one of the earliest, hardiest and most productive of beans. The pods are long. showy, very tender, stringless and of most excellent quality. Pkt 5c.; 1/2 pt 15c.; pt 25c.; qt 40c., postpaid. By ezpress or freight, qt $25 \mathrm{c}$. : 4 q ts $95 \mathrm{c}$; peck $\$ 1.80$.

DAVIS WHITE WAX--Very productive; bearing large, straight, handsome pods in great abundance, The pods are 5 to 6 inches long and almost without flesh. It is a good shipper, fine for canning, as it does not discolor and the dry beans are large, pure white and fine for winter use as shell beans. Pkt $5 \mathrm{c} ., \mathrm{x} / 2$ pint $15 \mathrm{c}$., pint $25 \mathrm{c}$., qt $40 \mathrm{c}$, postpaid. By express or freight. qt $25 \mathrm{c}, 4$ q ts $90 \mathrm{c}$, peck $\$ 1.80$

Zimmerman's German Wax.

We have here a very select strain of German Wax Bean and have received many letters from Gardeners over the country complimenting the superior quality of our strain of German Wax Beans, They all pronounce it Trie EARLIEST WAX BEAN IN CULTIVATION and one of the very best. The pods are a beautiful golden waxy color; of good size round, slightly curved, meaty tender, and of the highest quality and stringless. It is very productive and cannot be exoelled as a home or market bean. Pkt 5c.; 1/2 pt 12c. ; pt 20c.; qt 35c., postpaid. By express or freight, qt 20c.; 4 qts 75 c. : peck $\$ 1.40$.

DWARF BLACK WAX---An old favorile and popular in many sections. Same price as German Wax.

If your order will amount to Five Dollars, see our Wholesale Price-List to Market Gardeners on Pages 61 and 62.

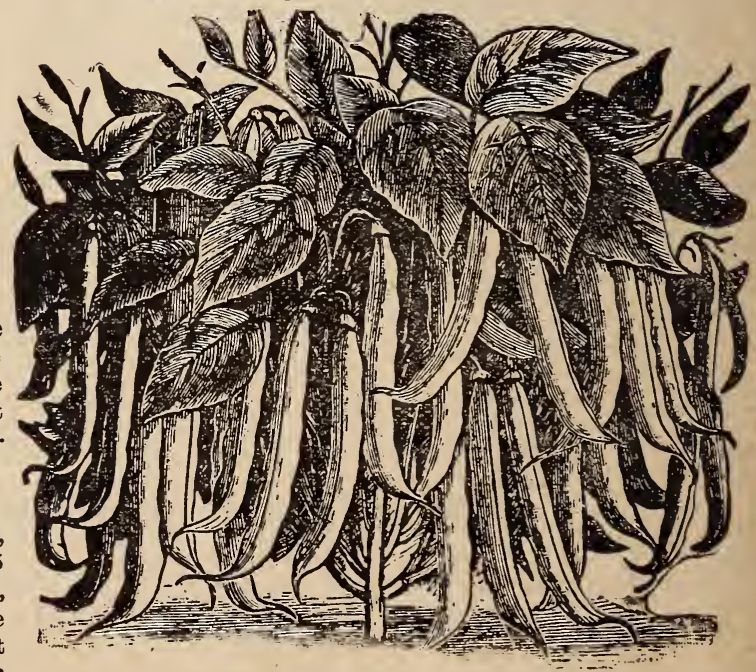

WARDWELL'S KIDNEY WAX. 


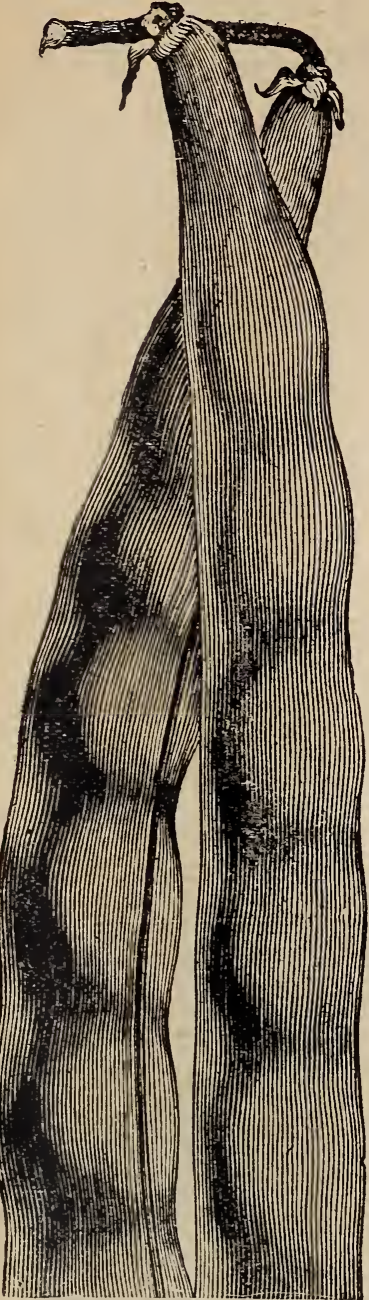

Kentucky Wonder

\section{Bush Limas}

We offer the two greatest varieties of Bush Limas. Our seed is all bright, new and fresh crop of 1906. It's all "top notch" quality-none better than ours, and the price is right.

BURPEE'S BUSH LIMA-The leading lima bean; grows to a height of 18 to 20 inches, forming a circular bush over two feet in diameter. Requires no poles or stakes and is a tremendous yielder. The pods are of large size and each pod produces 3 to 4 mammoth beans of fine flavor and tenderness. The largest bush lima bean grown. Pkt. 5c, $1 / 2$ pt. $15 \mathrm{c}$, pt. 25c, qt. 40c, postpaid. By express or freight, qt. $25 \mathrm{c}, 4$ qts. $80 \mathrm{c}$, pk. $\$ 1.50$.

HENDERSON'S BUSH LIMA-This is the earliest lima bean; not so large as the Burpee, but is earlier. They are very productive and grow in compact form, without poles or stakes, and produce large crops of delicious beans which can he easily gathered. What they lack in size they make up in earliness, hardiness, and continuous productiveness. They are 10 days ahead of any other lima bean. Pkt. 5c, $1 / 2$ pt. $15 \mathrm{c}$ pt. $25 \mathrm{c}$, qt. $40 \mathrm{c}$, postpaid. By express or freight, qt. $25 \mathrm{c}, 4$ qts. $90 \mathrm{c}, \mathrm{pk}$. $\$ 1.50$.

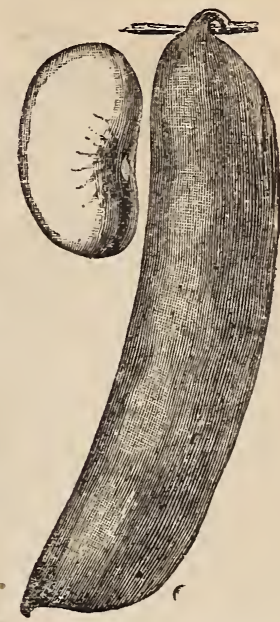

\section{Beans, Pole or Running}

Pkt., 5c; $1 / 2$ pint, 12c; pint, 20c; quait, 35c postpaid.

By express or freight, quart, 20c; 4 quarts, 75 c; peck, $\$ 1.40$.

KENTUCKY WONDEIR-I consider this one of the best ai:d most profitable beans grown. The pods usually measure over 7 inches in length and are so filled with large meaty beans that they are greater in width than breadth. They are of the finest quality entirely stringless and wrll bear heavily the entire season. There is no better bean on the market than the Kentucky Wonder and my stock is selected with great care. Be sure to try this grand bean.

LAZY WIFE-Pods six inches in length, produced in great abundance; broad, fleshy and entirely stringless; possess a rich buttery flavor when cooked. As a shell bean for winter they have few equals and no superior.

CUTSHORT or Cornhill - This is an old and very popular variety for planting among the corn. In some sections it is used almost exclusively, many persons desiring no other. The pods are short, round and very tender; beans llearly oblong.

KING OF TH E GARDEY, IIYA-The largest, finest and best pole lima bean grown The pods sre of enormous size and produce 5 to 7 large beans to the pod. Market gardenrs can secure a more ready sale and better price for this variety than any other, on ac tount of its large size coupled with superior quality.

EARLY GOLDEN CLUSTER WAX--Begins to bear eaaly in July and continues until frost. Pocs dre 6 to 8 inches long, borne in clusters of 3 to 6 and are of a beautiful golden yellow color, and the flavor is deliciou 3 . Can be used either as a string bean or shelled

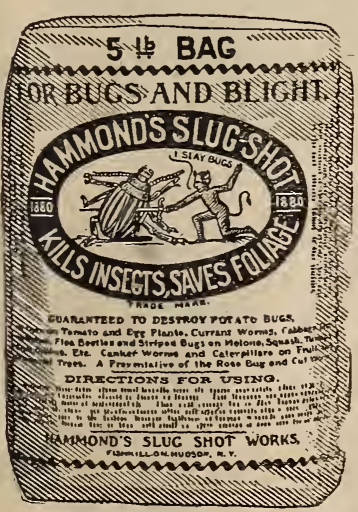

\section{HAMMOND'S SLUG SHOT. The Very Best Bug and} Insect Killer on the Market.

It is thoroughly reliable in killing Potato Bugs, Cakbage Worms, Currant Worms, Sow Bugs. Chicken Lice, Mites, Etc. It is a light composit powder, easily distributed by duster, bellows or spraying in water or dusting by hand. It is harmless to anything but insects. IT NEVER FAILS.

Sure death to Cucumber Vine Beetles and Squash Vine Bugs

Price 20c per lb.; 3 lbs 50c., postpaid. By express or freight, 5 lbs $35 \mathrm{c} . ; 10$ lbs $60 \mathrm{c}$.; $50 \mathrm{lbs} \$ 2.50,100 \mathrm{lbs} \$ 4.50$.

DUSTERS For applying Slug Shot or any and all powders. Qt size 30c., 2/2 gal size 35c., gal size 50c. By express or freight.

SPRA TRRS. THE LEE--."Only sprayer of this kind that will spray entire contents of the can in any direction" house or for spraying bushes, plants, shrubbery, etc. P rice 50c. Post liduid lice 

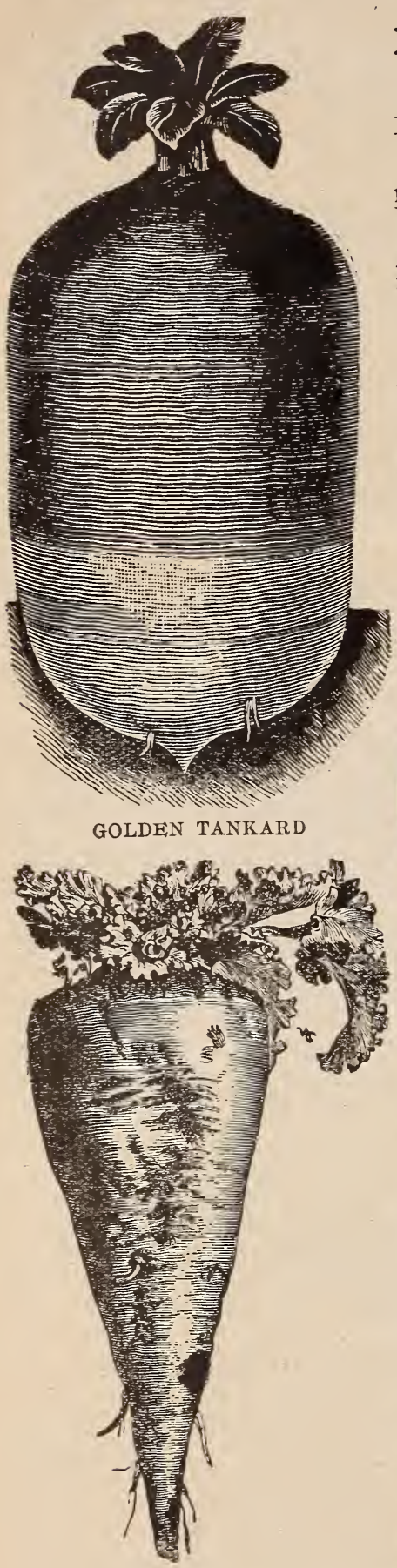

WANZLEBEN SUGAR BEET

HAT FONG BIOON BEET-

HALF LONG BLOON BEn beet A stalidard sun:mer and autrimn beet end superior to the o?d Long Blooct. A ? way sweet and tender. Hkt 5cog BC., 1/10 15c., 10 50c, postpaid.

¿WTSS CEARD--Also calied Silves Eeet. Most Ċlicious for greens and comes early. Jater they lormi min-like siems, which are ve $y$ delicious, is stems, wike beets. Pkt Ek, on 100, :

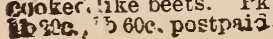

\section{MANGEL WURZLE AND SUGAR BEETS}

Price of any the following, oz $5 \mathrm{c}$; $; / / 4 \mathrm{tb} 12 \mathrm{c} ; 1 / 2 \mathrm{tb} 20 \mathrm{c} ; \mathrm{tb} 30 \mathrm{c}$, postpaid. By express or freight, $5 \mathrm{tb}$ and over at $20 \mathrm{c}$ per $1 \mathrm{~b}$.

GOLDEN TANKARD---Best yellow Margel in cultivation Contains more sugar and less water than any other variety and it is claimed stock will pick this variety from others Very hardy and will yield 25 tons per acre

IMPROVED MAMMOTH PRIZE---Sometimes called Norbitant Glant, Jumbo, etc. Is a mammoth variety and grows about two-thires out of the ground. Single roots have weighed 25 pounds.

LONG RED---Poots grow to an enormous size and are fiue for stock.

LANE'S IMPERIAL SUGAR---Very popular and productive sugar beet. Contains a large per cent of sugar and is one of the best for stock feeding.

IMPROVED WANZLEBEN SUGAR---Is the best beet for the manufacture of sugar. Root is conical, straight and even: large at the head and tapering. Exceedingly hardy and easily pulled.

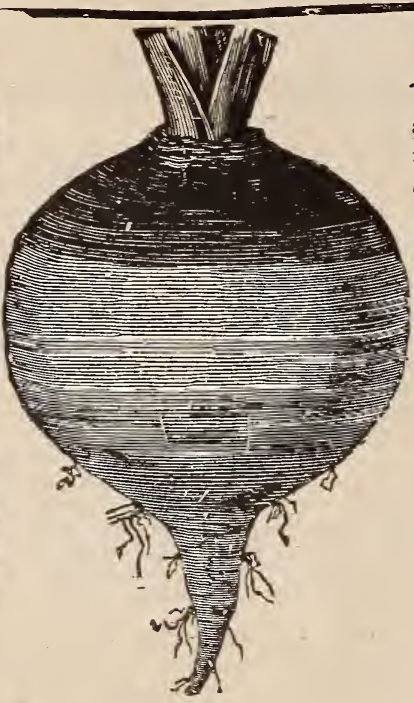

ZIMMEKMAN'S ELECTP.IC,

OEZOSBV'S EGTPTIAN-1s an im(1) Old Egyptian and ts of excellent quality. Deed red, almost blsck in color. Pkt 5c., oz 8c., 1/4 ib $15 \mathrm{c}$., ib 50c., postpaid.

EXTRA ESRLY EGXPTIAN-The cld nopu'ar variety and still claimed by mup to he earliest. Pkt 5c., oz 8c., ? is $10 c .$, ib $50 c$, postpald.

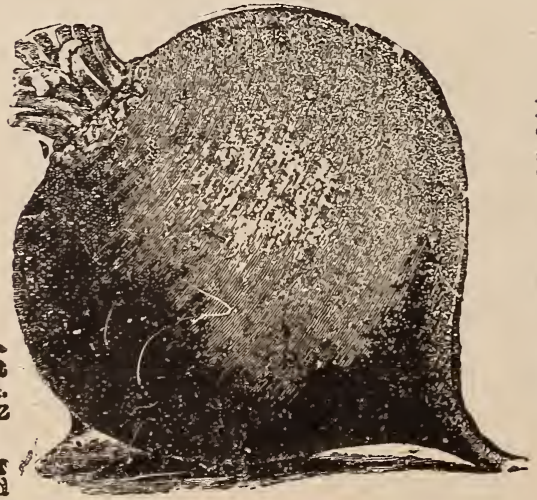

FAF, I, TCLIP.8F.

\section{Garden Beets.}

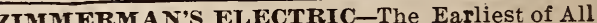
and one of the very best, We have brought up our Electric Beet to where it easily:leads all other early beets, being always ir the market several days ahead cf any other. If you have been planting some variety tric along beside the other and have your beets earlier than ever before. It is remarkably tender, sweet and \begin{tabular}{l} 
free from tounh fibre. A very rich dark crimson color \\
\hline
\end{tabular} ma $20 \mathrm{c} ., 1 / 2$ lb $35 \mathrm{c} .$. lb $60 \mathrm{c}$, postpaid.

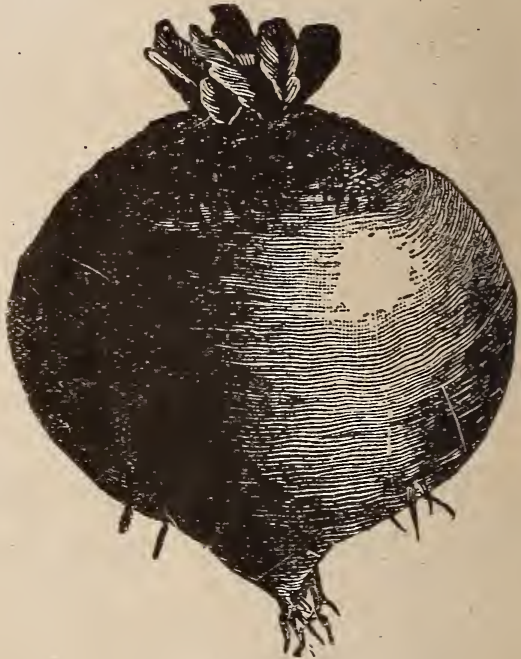

EDMAND'S BLOOD TLRNIP.

EDMAND'S BLOOD TURNIP BEETHas short top is round and smooth: flesh \& deep blood red. very oweet and tender. It grows to good size and very regular. One gr the best for market and table use. Pkt 5c, oz 8 c.. $1 / 4$ lb 15 c., lb 50c., postpaid. purplish green, Beets are perfectly smooth, purph and intense blood red flesh and skin sound, and inters Pkt 5c., oz 8c., $1 / 4$ lb 15c. lib 50c., postpaid.

FXTRA EARLY LENTZ-Early as the EXTRA late Egyptian, large and of fimes and is light red. keeper, sweet at all 1b 15c., 1b 50c, postpaid.

DETING'S IMPROVED BLOOD-A fine turnip beet and grows to a large size The flesi is deep blood red and of gond qual paid. ela imed to be the earliest. just sow some of our Elec-

EARI 7 ECLIPSE-Small tops of dark 
All expert gardeners nuuw that Cabbage seed grown upon Long Island is of greater vitality and will come truer than seed grown at any other part of the world. Our Cabbage seed was grown and shipped direct tc ' 3 from Long Island, N. Y., We handle nothing but THF' BEST.

\section{ZIMMERMAN'S EARLIEST.}

\section{Earliest Cabbage in the World.}

Well knowing the demand for a reliable extra early variety, spared neither time nor expense to secure the earliest variety possi. ble and feel safe in saying I have here the EARLIEST VARIETY EVER OFFERED. Many seedsmen are claiming to have the earliest, but a trial will show MY Earliest to be many days ahead of anything on the market. It is not only the EARLIEST, but reliable in every way and can be depended upon to yield good size marketable heads of fine quality. Almost every plant forms a fine, solid head in a remarkably short space of time. It makes a close, compact plant, can be set close together and yield large crops. Don't fail to include a packet of THE EARLIEST in your order. You will be well pleased. Market gardeners will find this grand variety very profiti,ble for extra early market. Pkt 5c, oz 25c, $1 / 41 \mathrm{lb} 65 \mathrm{c}, 1 / 2 \mathrm{lb} \$ 1.15$ postpaid.

EARLY WINNIGSTADT-A good extry early variety and very popular. Forms large cone-shaped heads of fine quality in seasons when other early varieties fail to head a all. It suffers less from worms than most any variety. Pkt 5c, oz $15 \mathrm{c}, 1 / 41 \mathrm{lb} 45 \mathrm{c}, 1 / 21 \mathrm{~b} 80 \mathrm{c}, 1 \mathrm{~b}$ 81.50 postpair.

EARLY JERSEY WAKEFTELD-My stock of this old reliable variety is the best, being true Long Island crop - This is one of the best early cabbages in cultivation and is very popular and too marketable heads in 100 days or less. Remember I handle no old stock and guarantee seed as true stock, crop c.f 1909 , Do not buy old and inferior seed. Pkt. $5 \mathrm{c}, 0 \mathrm{z} 20 \mathrm{c}, 1 / 4 \mathrm{lb} 60 \mathrm{c}, 1 / 2 \mathrm{lb} \$ 1.00,1 \mathrm{~b} \$ 1.90$, postpaid.

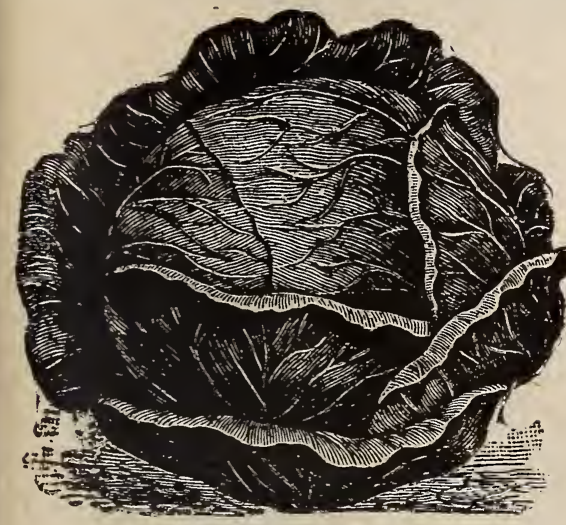

ALL HEAD EARLY.

\section{ZIMMERMAN'S SUREHEAD.}

All head and always sure to head. This is a large main Crop variety of the Flat Dutch type. It is sure to form large round heads, extra hard. firm and of superior quality and fine texture. It ia an excellent variety for Southern and Southwestern growers. on account of its sure heading qualities, as many varieties fail to head in this section. You will not be disappointed in this sureheading cabbage. It is alsn one of the largest cabbages grown, averaging 2bout 25 pounds, but specimens have been grown to weigh over $50 \mathrm{lbs}$. It is a good keeper, excellent shipper; in fact it is hard to surpass this grand cabbage. Pkt 5c., oz 18c.; 1/1 1b50c., 1/2 lb 90c., lb 81.70, postpaid. KOHL.RABI TURNTP-ROOT

A vegetable botween the cabbage and turnip and combining the flavor of both. The stem forms a turnip-shaped bulb, which should be cut when it is mall. White Giant-Pkt 5c., oz 20c., $1 / 4 \mathrm{lb} 60 \mathrm{c}$.

\section{All Head Early Cabbagee}

As can be seen from the engraving, this is atarge, early, round-headed cabbage. For size, earliness, reliability of heading and quality it has no equal. It is the finestlarge summer cabbage on the market, being at least one-third larger than any other early summer cabbage. The heads are solid and so compact that nearly one thousand more can be grown per acre than any other cabbage. On account of its rapid growth, it is very tender and the flavor is unsurpassed. Pkt. 5c, oz 20c, $1 / 41 \mathrm{lb} 55 \mathrm{c}, 1 / 2 \mathrm{lb} \$ 1.00,1 \mathrm{~b} \$ 1 \cdot 90$ postpaid.

EXTRA EAREY EXPRESS-With the exception of my EARLIEST, this is probably the earliest cabbage on the market. Is of close compact habit; has few lonse leaves and is of fine quality. Pkt 5c, oz $18 \mathrm{c} .1 / 4 \mathrm{lb} 50 \mathrm{c}, 1 / 2 \mathrm{lb} 90 \mathrm{c}, 1 \mathrm{~b} 81.75$ postpaid.

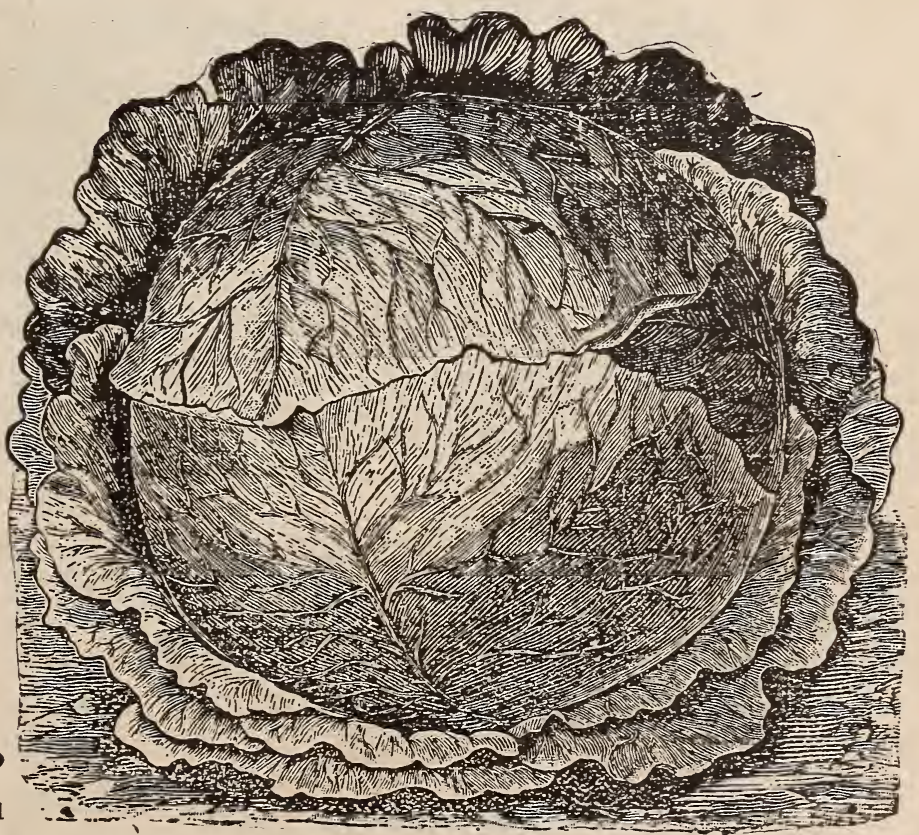

ZIMMERMAN'S SUREHEAD 
GIAN' FLAT DUTCF - Ar extra large late win. ter variety, which has no superior and is one of the old standard varieties. Market gardeners plant largely of this variety ond realize a good profit. On account of its extra large size, it never fails to bring high prices in the market. It is of sureheading stock, has short stem and is a compact grower. Pkt., 5e; oz., 15c.s $1 / 4$ 1b., 45c.; $1 / 2$ 1b., 80c.; lb.g. 1.50, postpaid.

SHORT STEM DRUEF. HEAD - This is one of the very best varieties of winter cabbage. Heads are of immense size, hard and solid. They grow uniform in shape with short stem and are very handsome in appearance. On account of their large size and fine quality, they are highly prized and I offer them as something superior in cabbages. Give them a trial. Pkt., 5c; oz., 18c; $1 / 41 \mathrm{~b} ., 50 \mathrm{c} ; 1 / 21 \mathrm{~b} ., 90 \mathrm{c} ; 1 \mathrm{~b}$.,
$\$ 1.65$, postpaid.

THE LARGE LATE DRUMHEAD - A stand. ard variety of the Flat Dutch type. Late and very large. Pkt., 5c; oz. 15c.; 1/4 lb., 45c.; 1/2 lb., 80c.; lb., $\$ 1.50$, postpaia.

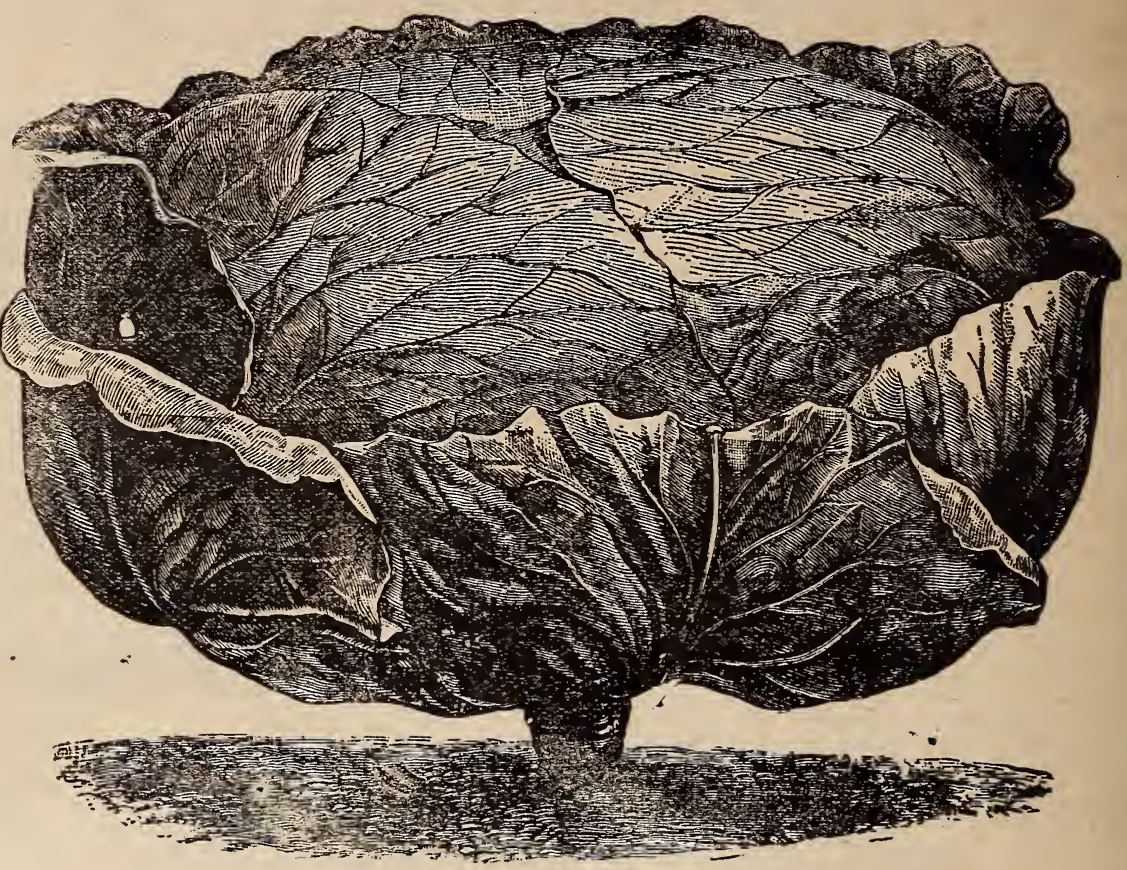

ALL SEASONS-Can be planted profitably for either early or main crop; is of drumhead type. In every way equal toth Early Summer and much larger. Pkt 5c.; oz 18c.; 1/4 lb 50c.; $1 / 21 \mathrm{~b} 90 \mathrm{c}$. ; $1 \mathrm{~b} \$ 1.70$ postpaid.

MAMMOTH RED ROCK-The largest and surest heading red cabbage grown. Heads are of deep red color inside and and very solid. A favorite for salads, pickling, etc. Pkt 5c.; oz 18c.; 1/4 1b 50c.; 1/2 ib 90c ; $1 \mathrm{~b} \$ 1.70$ postpaid.

\section{Zimmerman's Genuine Danish Ball Head Cabbage.}

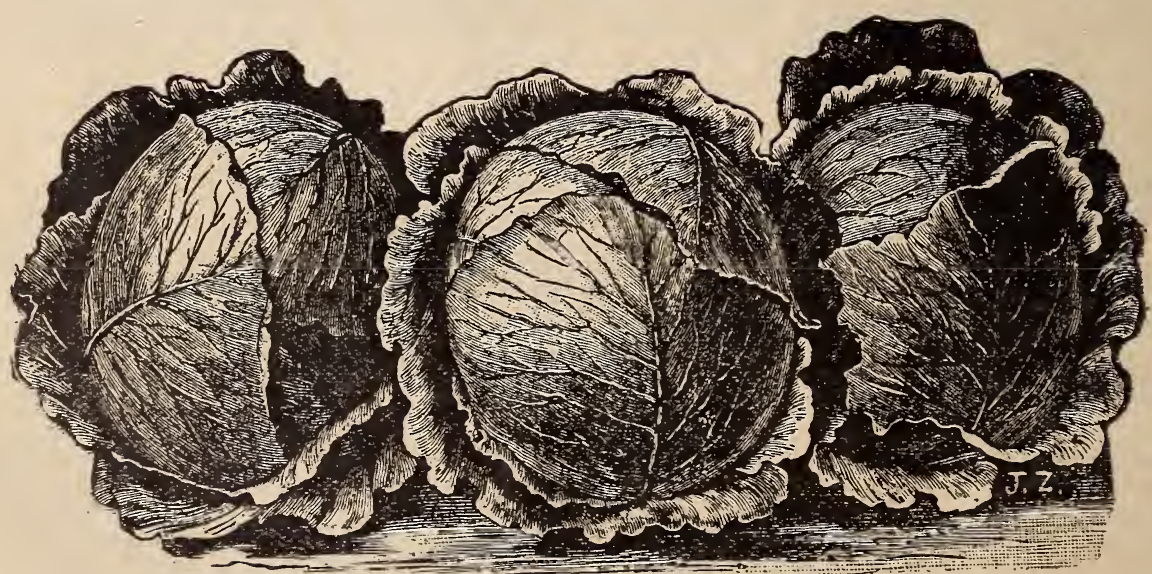

IMPROVED DANISH BALL-HEAD - The famous variety from Denmark. Not so large as the Late Flat Dutch or Short Stem Drum-Head, but are even harder and more solid and are the finest and best keepers to be had. For winter, home and market use, they stand without a peer. Their keeping qualities are such that when taken out in the spring they are as solid as when put away in the fall. Pkt., 5c., 3 pkts $12 \mathrm{c}$., oz 20c, 1/4 lb 60c., 1/2 $1 \mathrm{~b}$. $\$ 1.10$; lb 2.00 postpaid.

ST. LOUIS MARK ET-Is a very vigorous and hardy grower. Head is solid, white and large. Is a medium late cabbage and is an excellent keeper, being a good shipper. Is fast becoming a favorite with market gardeners; As a kraut maker it can not be excelled. Pkt 5c., oz 20c., $1 / 4 \mathrm{lb} 60 \mathrm{c}$., $1 / 2 \mathrm{lb} \$ 1.10,1 \mathrm{~b} \$ 2.00$.

EARLY SUMMER-Is one of the best large early cabbages, forming solid, compact heads. Pkt $5 \mathrm{c} ., 0 z 20 \mathrm{c} ., 1 / 4 \mathrm{lb} 60 \mathrm{c}$., $1 / 2 \mathrm{lb}$ $\$ 1.10,1 \mathrm{~b} \$ 2.00$. 


\section{Cauliflower.}

Our Cauliflower seed is guaranteed to be LONG ISLAND GROWN, which is the best in the world. We all know that old seed never produces good crops; our seed is NEw CroP

and we handle ONLY THE BEST VARIETIES.

\section{Early Snowball.}

It is acknowledged everywhere that the Snowball Cauliflower is far superior to any other variety. I am pleased to offer my customers a superior strain of this superior variety. In fact, it is imposs:ble to obtain a better Caulifower than my Early Snowball. While this remarkable variety is First of the Earlies, it is also the best for main or late crop; in fact, it has no equal in any line. It is the largest varlety grown, heads measuring eight to ten inches across, of pure snow white, with close, compact curd of the finest quality. The heads are so solid that they outweigh any other variety of the same size. Whether you grow Cauliflower simply for family use or largely for market, my Early Snowball is the variety you want. Plant no other if you want the VERY BEST. Once planted, you will use no other. Pkt., 15c; a pkts., 25c; $1 / 4$ oz., 70c; $1 / 2$ oz., $\$ 1.30 ; 0 z$. $\$ 2.50$, postpaid.

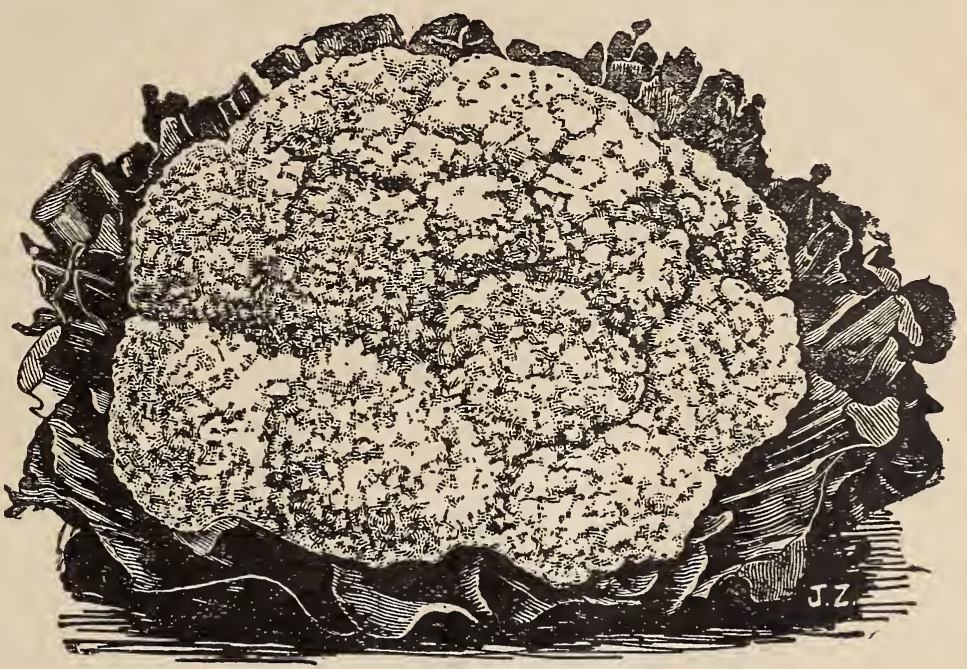

ZIMMERMAN'S EARLY SNOWBALL

EARLY DWARF ERFURT - Another remarkable varlety for heading. Is dwarf; pure white heads of superi: quality. Planted in April, will be ready for market in July. Pkt., 15c; 2 pkts., 25c; 1/4 oz., 75c; $1 / 2$ oz., \$1.40; 0z. $\$ 2.75$, postpaid.

EARLY PARIS FORCING - A favorite French variety and a very popular early sort. Good for either forcing or out-door culture. Pkt., 5c; $1 / 4$ oz., $25 \mathrm{c}$; $1 / 2$ oz., $45 \mathrm{c}$; oz., $80 \mathrm{c}$, postpaid.

ALGIERS -A strong growing, extra large late variety. Produces larrge solid heads late in the fall. Pkt., 5c: 1/4 oz., 25c; 1/z oz., 45c; oz., 80c, postpaid.

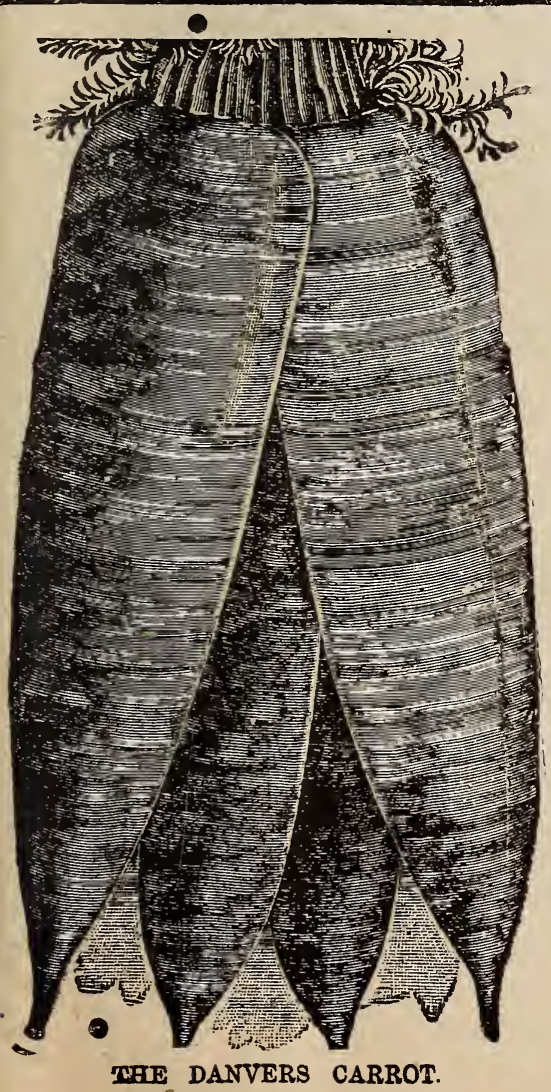

\section{CARROTS.}

Vox-hEART or GUERRANDE-A very fine Carrot; grows some five inches long and blunt at the point, as shown by the illustration. It is of very rapid growth and usually weighs over one pound. Is of deep red color, very sweet and tender and easy to pull. A good variety for home and market. Pkt., 5c; oz., 10c: ket. $15 \mathrm{ckt}$., 5c; oz., 10c; ${ }^{2}$

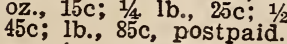

Chantenay - The best bunching variety and one of the best for early market. Grows about six inches long, stump rooted, very smooth, sweet and sugary. Excellent for ta-

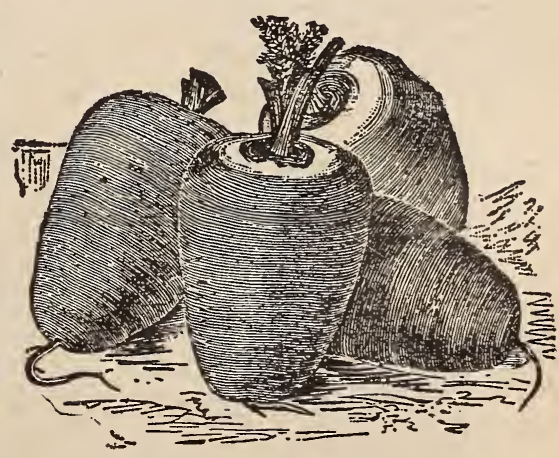

OX-HEART OI GUERANDE. ble use and are heavy croppers.

$100,1 / 4$ lb., 25c; $1 / 2$ 1b., 45c; lb., $85 \mathrm{c}$, postpaid.

DANVERS HALF LONG - A famous variety of fine flavor; broadshouldered, stump rooted, cylindrical in shape and very productive. It is one of the best for stock and matures in about 65 days. This is nof only a good variety for stock feeding, but is unexcelled for the table. Pkt., 5c; oz., 10c; $1 / 4$ lb., 25c; 1/2 lb., 40c , lb 75c. postpaid.

VIMPROVED LONG ORANGE - The best of the orange varieties and an old favorite. A good table carrot and is unsurpassed for stock. Used largely by dairymen, as it increases the flow of milk and gives a richer flavor: imparts a beautiful golden color to butter. Pkt., 5c; 0z/, 10c; 1/4 lb., 25c; $1 / 2$ lb., 40c.; lb 75c, postpaid.

ILARGE WHITE MELGIAN The greatest stock Carrot, highly recommended by the leading Agricultural Experiment Stations of the country. Grows one-third out the ground and easily pulled. Rootg are pure whits, except portion above ground, which is green. Used exclusively for stock feeding. Pkt., $5 \mathrm{c} ; 0 \mathrm{z}$., 8c; $1 / 4 \mathrm{lb}$., 15c; 1 is $1 \mathrm{~b} ., 25 \mathrm{c}$ b\%, 45c. nostpaid.

RARGE YELI.

in color. which is WELGIAN - Same as the White Belgian, excon in color. which is yellow. Same price as the White. 


\section{*T Celery seed is very slow to germinate and care should be taken that the seed is of good quality. You will find our stock to be the very best quality and prices as low as good seed can be sold.}

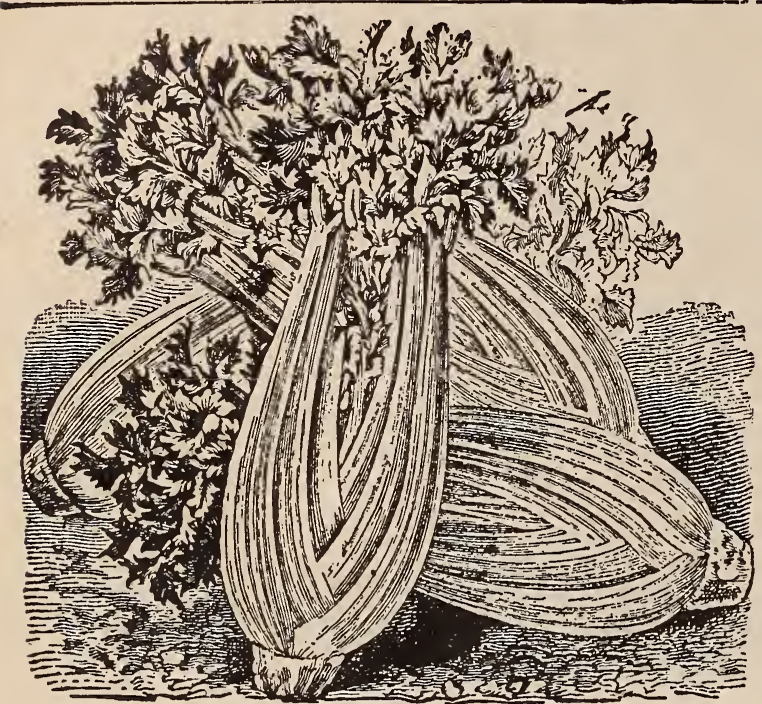

GOIDEN SELF-BLANCHING (FRENCH STRAIN)

\section{New Golden \\ Self-Blanching.}

(French Strain.)

This is without doubt the best celery in cultivation. It is much broader and heavier than the White Plume and of superior quality. Is of dwarf, compact habit and blanches easily. The stalks are crisp and solid and of delicious flavor; is very productive and the stalks are as thick as the largest of the tall late sorts and entirely free from stringiness. It is the standard of excellence and should be planted by every person who raises celery. We offer the celebrated French seed of this variety as far superior to the Ordinary strain, generallv sold. You will find it superior in many ways. Per pkt., 5c; $1 / 2$ oz., $15 \mathrm{c} ;$ oz., $25 \mathrm{c} ; 1 / 4 \mathrm{lb}, 75 \mathrm{c} . ; 1 / 2 \mathrm{lb}$., $\$ 1.40 \mathrm{Ib} \$ 2.50$ postpaid.

Ordinary Strain-This is not cheap seed. but simply the ordinary American strain of Golden Self-Blanching, which is offered by the general run of seedsmen. Stock is fresh 1905 seed and the equal of any American-grown seed. Pkt 5c.; $1 / 2$ oz 12 c. ; oz 20c. ; $1 / 4$ lb $60 \mathrm{c}$. ; $1 / 2 \mathrm{lb} \$ 1.10 ; 1 \mathrm{~b} \$ 2.00$ postpaid.

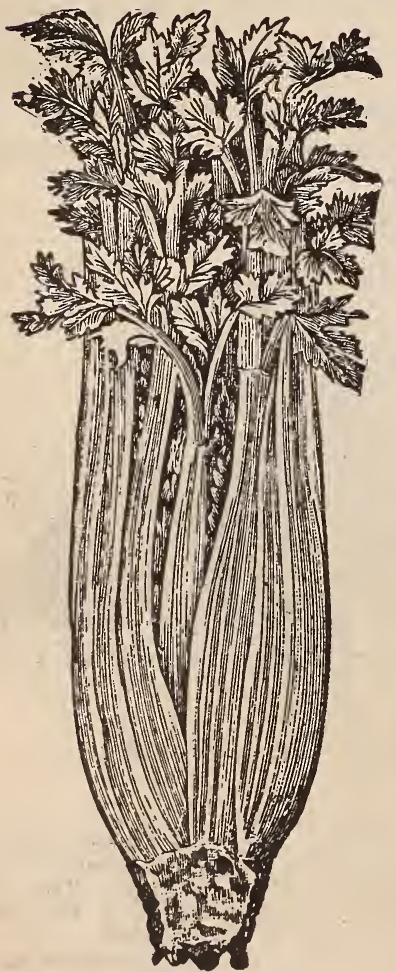

NEW PINK PLUME.

NEW PINK PLUME-This is a splendid new variety, recently introduced; is similar to the White Plume, except in color, which is slightly tinged red, fading to a faint delicate pink. The plants bleach naturally and have the long keeping qualities of the red celeries. Has no tendency to rust and blanches as early as the White Plume. Is of sweet, nutty flavor and wonderfully attractive. Pkt., 6c; $1 / 2$ oz., $12 \mathrm{c}$ : oz., $20 \mathrm{c}$; $1 / 4 \mathrm{lb}$., 55c; $1 / 2$ lb., $\$ 1.00$; lb., $\$ 1.90$, postpaid.

WHITE PLUME-The old standard variety and still holds its popularity. It is the earliest celery in cultivation blanches without banking.Pkt., $5 \mathrm{c} ; 1 / 2 \mathrm{oz}$., oc; oz., $15 \mathrm{c} ; 1 / 4$ lb., $40 \mathrm{c}$; $1 / 2 \mathrm{lb}$., $75 \mathrm{c}$; lb., $\$ 1.40$ postpa:d.

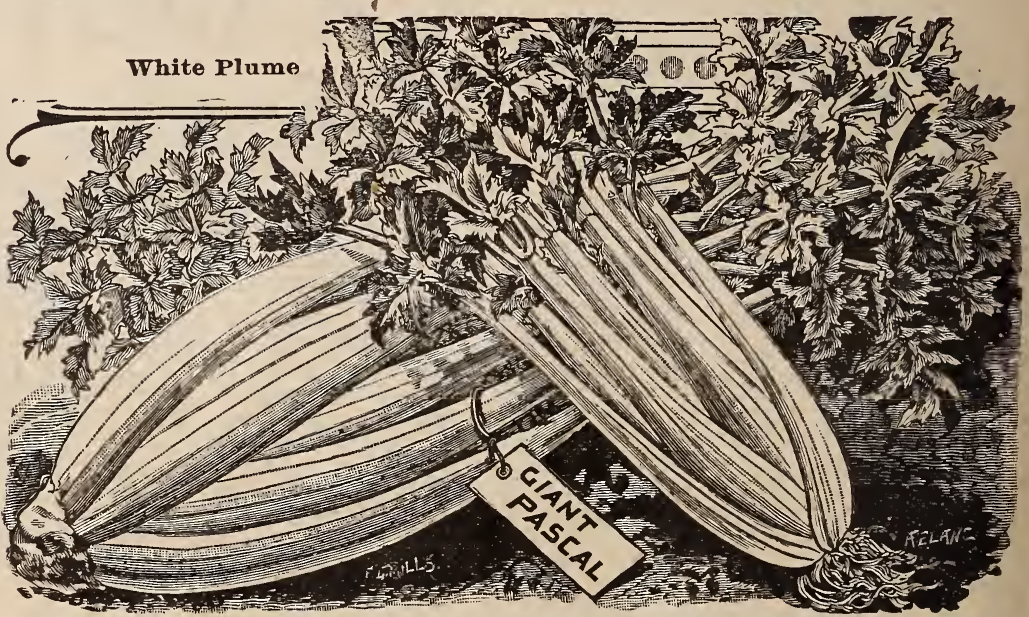

GIANT PASCAI - The stalks are extremely large, stringless, crisp and brittle Blanches quickly after earthing up to a beautiful yellowish-white. It is the est for Fall and Winter use and is highly recommended for the South and West where it gives better satisfaction than most varieties. Try it. Pkt., 5c; oz., $12 \mathrm{c} ; 1 / 4$ lb., $40 \mathrm{c} ; 1 / 2$ lb., $75 \mathrm{c}$; 1b, $\$ 1.40$ postbaid.

LARGE RIBBED RED - This is a sport of the Giant Pascal, but the ribs are even thicker and stiffer; very vigorous and healthy and of fine quallty. Pkt., 5c; oz., 12c; $1 / 4$ lb., 40c; $1 / 2$ lb., 75c.; lb., $\$ 1.40$ postprid.

CWTERIAC or TURNIP-ROOTED CELERY-Grown for the roots. The roots a re cooked, sliced and made into salad, with vinegar. Also fine for flavoring soups, meats, etc. Pkt 5c., oz 15c., 1/4 16 50c., postpaid.

a. Expert Market Gardeners buy their seed from us. Why? Because our seeds are Fresh, Pure and of the Highest quality. We KNOW this, because they are grown especially for us. .We positively do NOT. handle cheap."commission seed." Ad 
We wish to call your attention to our EARLY MAmoth for early plantiug' and Stowell's Evergreen for late or majn crop. eur Sweet Corn is of superior quality, being oarefully sorted and graded and is planteb each year by som of the forcmost Market Gardeuers in America.

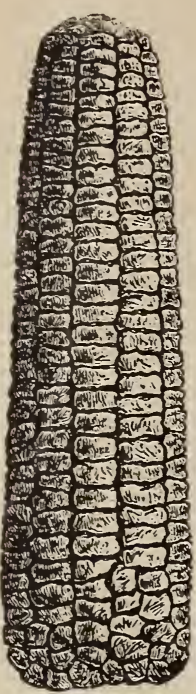

\section{Earliest of All.}

We are pleased to offer our customers the Earliest variety of Sweet Corn in the world. This must not be compared to the "Earlies" offered by some seedsmen, which are so small and inferior that they are absolutely worthless, but here is a variety that will be of greatest value to all who des.re the VERY EARLIEST variety and one that can be depended upon to yield a profitable crop. It is superior to the Early Cory in quality, tenderness and yield, while it is easily ten days earlier than any variety yet introduced. If you want the First Sweet Corn in the market plant this new variety. Pkt 6c; $1 / 2$ pt 12c; pt 20c; qt 35c, postpaid. By express or freight not prepaid, qt $25 \mathrm{c} ; 4$ qts $75 \mathrm{c} ; \mathrm{pk} \$ 1.25$.

\section{New Early Mammoth.}

The Largest Eared Early Sweet Corn Ever Froduced. Produces fine ears from 8 to 10 inches long and is ready for the market as early as the Earliest offered by the majority of seedsmen. Th:s is a corn we want you to try this season. Our stock is limited, as this is the 3rd season tris grand variety has ever been placed on the market, but we hope to supply all orders. Send in your order early, for you are sura to be pleased with this grand new corn. The pure white cob ccintains twelve rows of large grains of the finest quality. It will stand a dry season better than any early variety yet produced. It is the proper size for the market and of the sweetest flavor. You will find our EARLY MAMMOTH to be the finest and best Early variety you ever planted. Don't fail to include some of this Sweet Corn when you order. Pkt 5c; 1/2 pt $1 \mathrm{c} ; \mathrm{pt} 2 \mathrm{uc}$; at c, postpaid. By express or freight not prepa:d, qt $20 \mathrm{c} ; 4$ q ts $60 \mathrm{c}$; pk 1.00 .

EARLY CORY-A popular extra early variety and the favorite EARLIEST OF ALL with many planters. Pkt 5c; $1 / 2 \mathrm{pt} 12 \mathrm{c} ; \mathrm{pt} 20 \mathrm{c} ; \mathrm{qt} 35 \mathrm{c}$, postpaid. By. express or freight not prepaid, qt $20 \mathrm{c} ; 4$ qts $60 \mathrm{c} ; \mathrm{pk} \$ 1.00$.

COUNTRY GENTLEMAN-One of the Sweetest of SweetCorns and very pro ductive. The kernels are large and pearly white.Pkt $5 \mathrm{c} ; 1 / 2 \mathrm{pt} 12 \mathrm{c} ; \mathrm{pt} 20 \mathrm{c}$; qt $35 \mathrm{c}$, post pald. By express or freight not prepaid, qt 20c; 4 qts $60 \mathrm{c}$; pk $\$ 1.00$.

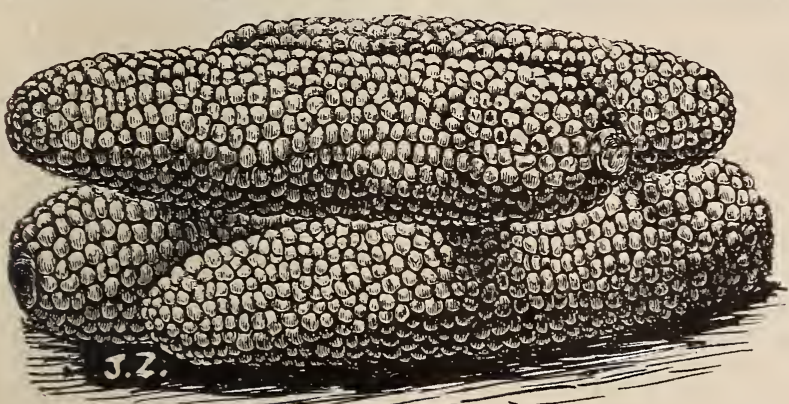

COUNTRY GENTLEMAN
ADAMS EXTRA EARLY-One of the very earliest varieties, Is not as sweet as sonle, but its extreme earliness makes it a very desirable curn. Pkt 5c., 1/2pt $12 \mathrm{c} \cdot$ pt $20 \mathrm{c}$, qts or freight, qt $20 \mathrm{c} ., 4 \mathrm{qts}$ $50 \mathrm{c}$. , peck $80 \mathrm{c}$

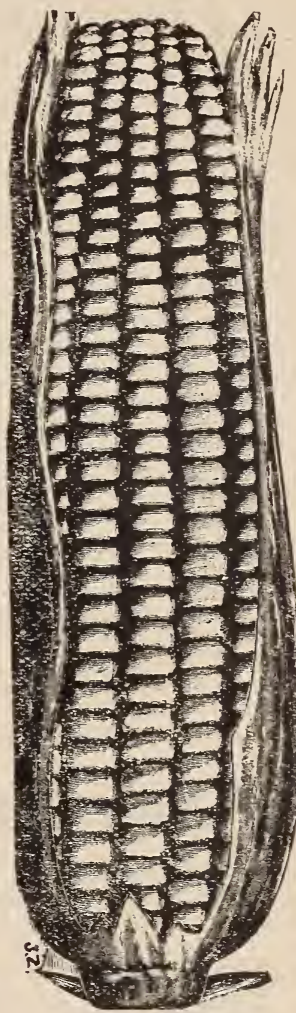

EARLY MAMMOTH.

CROSBY'S EARLY--This is a most excellent variety being sweet and delicious and also very early. The ears are of large size and medium length, Pkt 5c., $1 / 2 . \mathrm{pt} 12 \mathrm{c}$ pt $20 \mathrm{c} .$. qt $35 \mathrm{c} .$, postpaid. By express or freight, ut $20 \mathrm{c}$

We handle ONLY THE BEST. Try US this rear; We'll treat you RIGHT.

LATE MAMMOTH-The largest sweet corn grown and is of good qualisy, but is late. Stalks prodnce 2 to 3 ears. Pkt 5c-. 1/2 pt 12c., pt 20c., qt 35c., postpaid. By express or freight. qt 20c., 4 qts $60 \mathrm{c} ., \mathrm{pk} 1.00$.

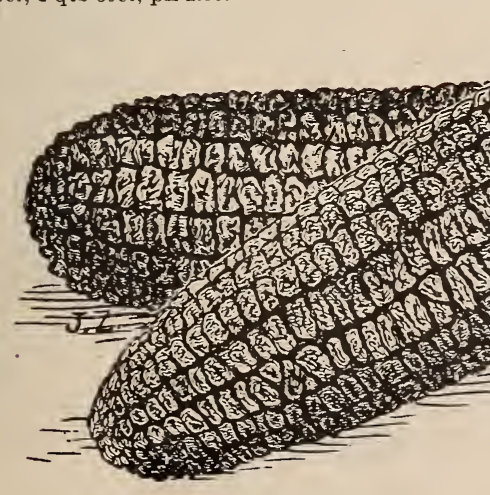

\section{SWEET CORN Continued on Next Page.}


IMPROVEDO

\section{Stowell's Everg'reen.}

The Standard Main Crop Variety.

This is the most popular variety of Sweet Corn on the market and is more largely planted than any other. It is undoubtedly the best sweet corn for main crop. Our stock of Stowell's Evergreen is vastly superior to that generally offered. If you want a sweet corn which will out-yield any other variety; of better quality than any other; that will give better satisfaction than any other, plant our Improved Stowell's Evergreen. Pkt 5c., 1/2 pt 10c., pt 15c., qt 25c, postpaid. By express or freight, gt 12c., 4 qts $45 \mathrm{c} ., \mathrm{pk} 85 \mathrm{c}$.

BLACK MEXICAN-There is no sweeter corn on the market. Is a medium early variety and when dry the kernals are black; when young they are a blueish-purple Plt 5c., $1 / 2$ pt 12c., pt 20c., qt 35c. postpaid. By express or freight, qt $15 \mathrm{c}, 4 \mathrm{qts} 50 \mathrm{c}$.

\section{SELECT POP CORN.}

WHITE RICE-The old standard and favorite variety. None better, Pkt 5c., $z / 2$ lb 10c., lb 15c., 3 lbs 40c., postpaid, By express or freight, 10 to $20 \mathrm{lbs}$ at $4 \mathrm{c}$ per $1 \mathrm{~b}$. 25 to $50 \mathrm{lbs}$ at at $3 \mathrm{c}$ per $1 \mathrm{~b}$.

GOLDEN TALE-Resembles the Queen's Golden, but a richer color, Earsgrow 8 to 10 inshes in leagth It is a fine popper and of excellent flavor. Same price as the White Rice.

WHITE PEARI-A White pearly pop corn. Very popular. Same price as the White Rige.

QUEMESS COLDEN-ROps $\approx$ large, tender, pure kernal. Same price as White Rice.
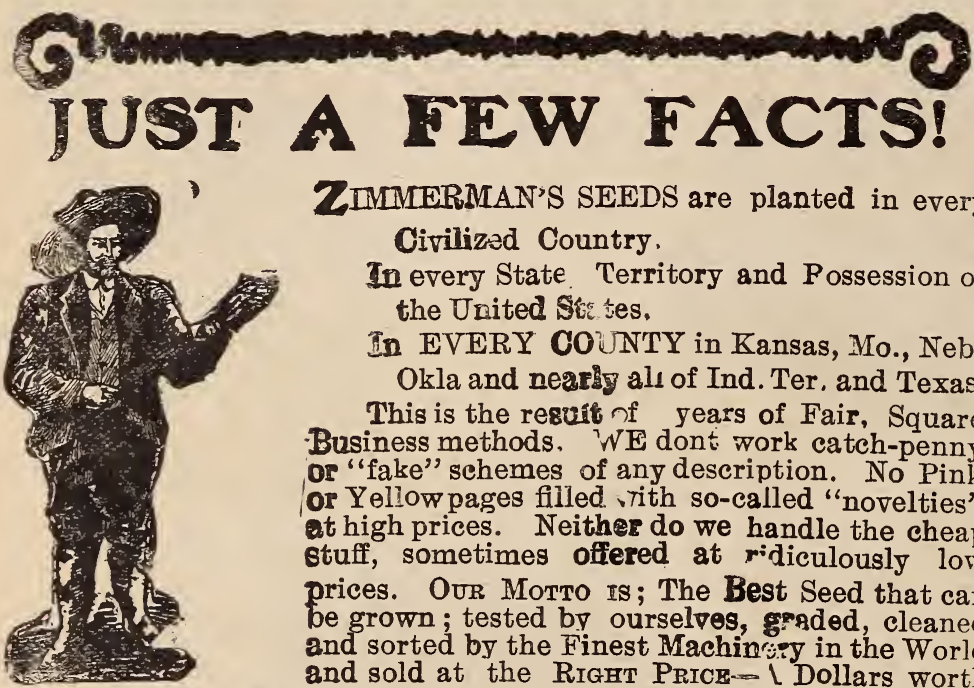

ZIMIMERMAN'S SEEDS are planted in every Civilized Country.

In every State. Territory and Possession of the United Sic ses,

In EVERY COUNTY in Kansas, Mo., Nebr Okla and nearsy alı of Ind. Ter, and Texas.

This is the resurt of years of Fair, Square - Business methods. "WE dont work catch-penny or "fake" sehemes of any description. No Pink or Yellow pages filled vith so-called "novelties" at high prices. Neither do we handle the cheap stuff, sometimes offered at ridiculously low prices. OUR Motro IS; The Best Seed that can be grown; tested by ourselves, grended, cleaned and sorted by the Finest Machine? in the World and sold at the RIGHT PRICR- - I Dollars worth tur A Dollar Do You like this way of doing besi-ess? If so, give us your orites this year, We'll treat You Righ'

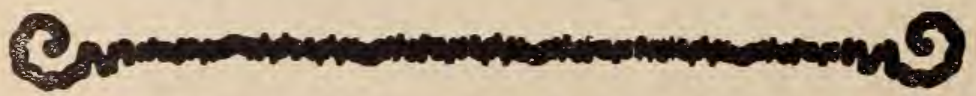

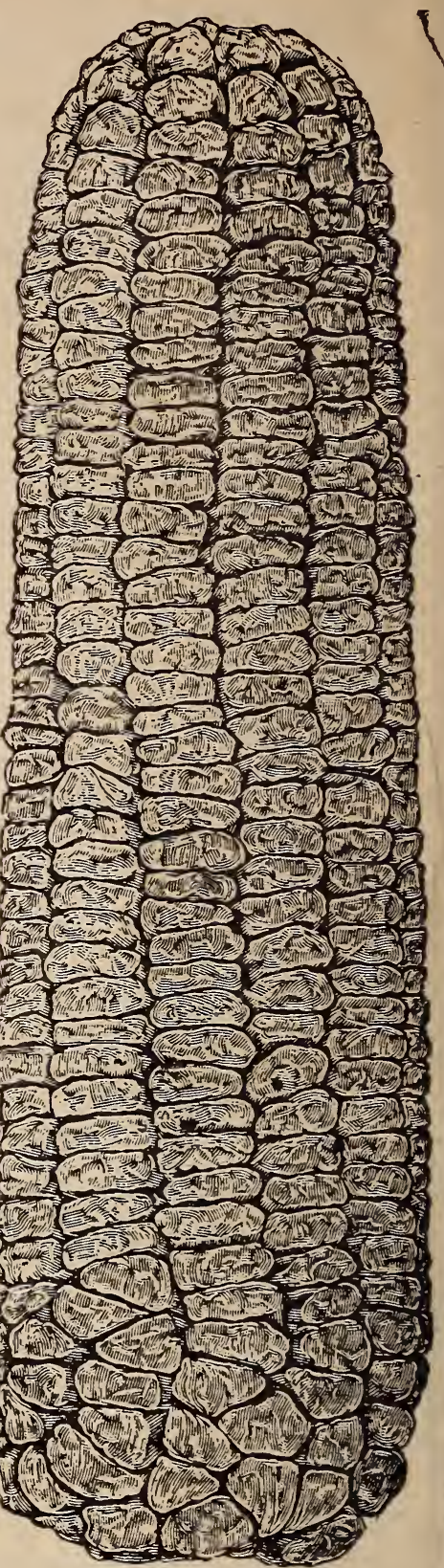

STOWELL'S EVERGREEA

\section{Special 50c. Vegetable Offer}

One large packet of each of the following varieties sent postpaid for ONLY 50c

BlinANS-Rust Proof Wax. Easly Ped Valentine, Bush LIma. BEETS-Egyptian. merman's Earliest. Improved Haneon. MUSK MGLON-Farliest Large. WATERMELON-Harris' Earliest. Triumph ONIONS-Augtralian Brown; PEAS-TwO Wcoke Early. RADISH-New Lightning. French Breakfast. . TOMATO-.. Early Beauty. In addition, you mas eoleot 160 worth Free. 
Our stock oi Cucumber seed is of the finest quality, being grown for us by the most experienced growers in America. One ounce will plant 50 hills ; 2 tó 3 lbs per acre.

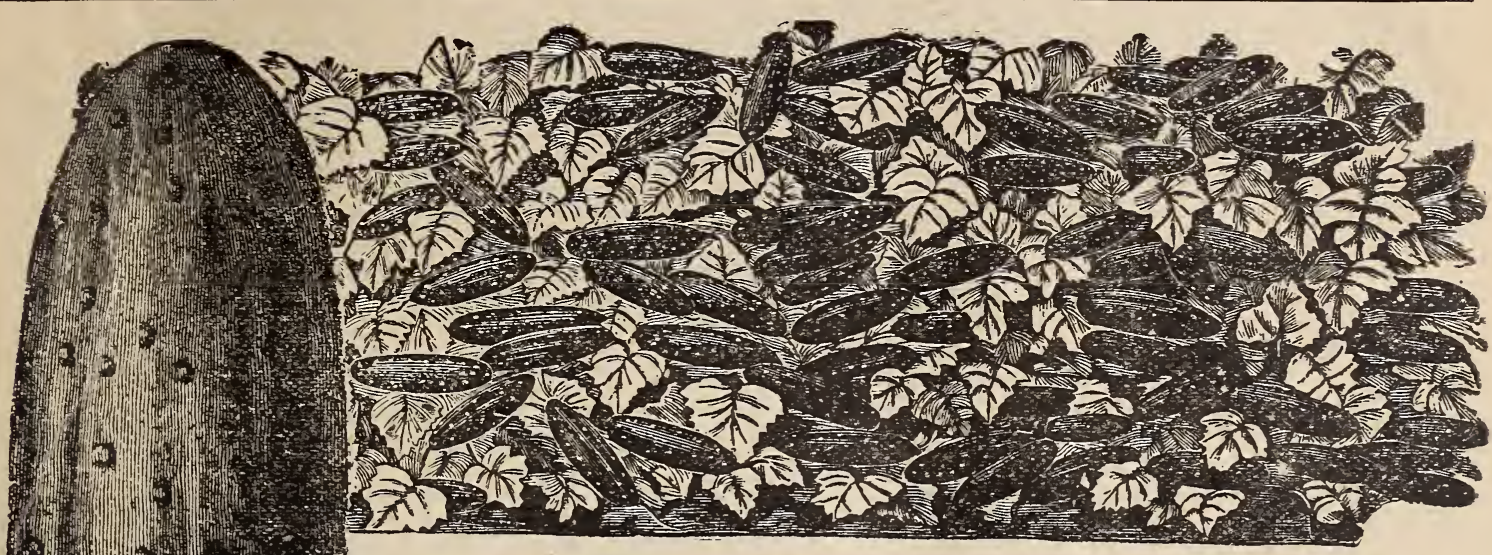

\section{ZIMMERMAN'S EAREIEST.}

\section{EARLIEST CUCUMBER AND A HEAVY YIELDER.}

The best early variety in the world. It stands without a rival in the early field and in fact cannot be excelled as a cucumber for general use. It is a very heavy yielder, producing cucumbers from five to eight inches long and from one and one-half to three inches in diameter in great abundance. The fruit is handsome, uniform in size and of a dark green color. The flesh is crisp, tender and of superior flavor. Not only fine for table use, it is excellent for pickling. If you want an all around cucumber, plant our Earliest. Pkt 5c; oz $10 \mathrm{c} ; 1 / 4 \mathrm{lb} 35 \mathrm{c} ; 1 / 2 \mathrm{lb} 60 \mathrm{c}$; $\mathrm{lb} \$ 1.10$, postpaid,

ZIMMERMAN'S EARI,IEST.

NICOLS MEDIUM GREEN-A first-class pickling sort and highly prized as an early variety. Skin is light green and quite smooth s kt. 5c. oz 10c., $1 / 4$ lb 30c. postpaid

WHITE SPINE-Fruit is of good size, straight and of perfect form : of uniform shape, making them excellent for pickling. Very productive and keep firm and crisp a long time Is one of the earliest varieties Pkt5c.: oz 10c.; $1 / 41 \mathrm{~b} 30 \mathrm{c} \cdot 1 / 21 \mathrm{~b} 50 \mathrm{c}$; $1 \mathrm{~b} 90 \mathrm{c}$, postpaid.
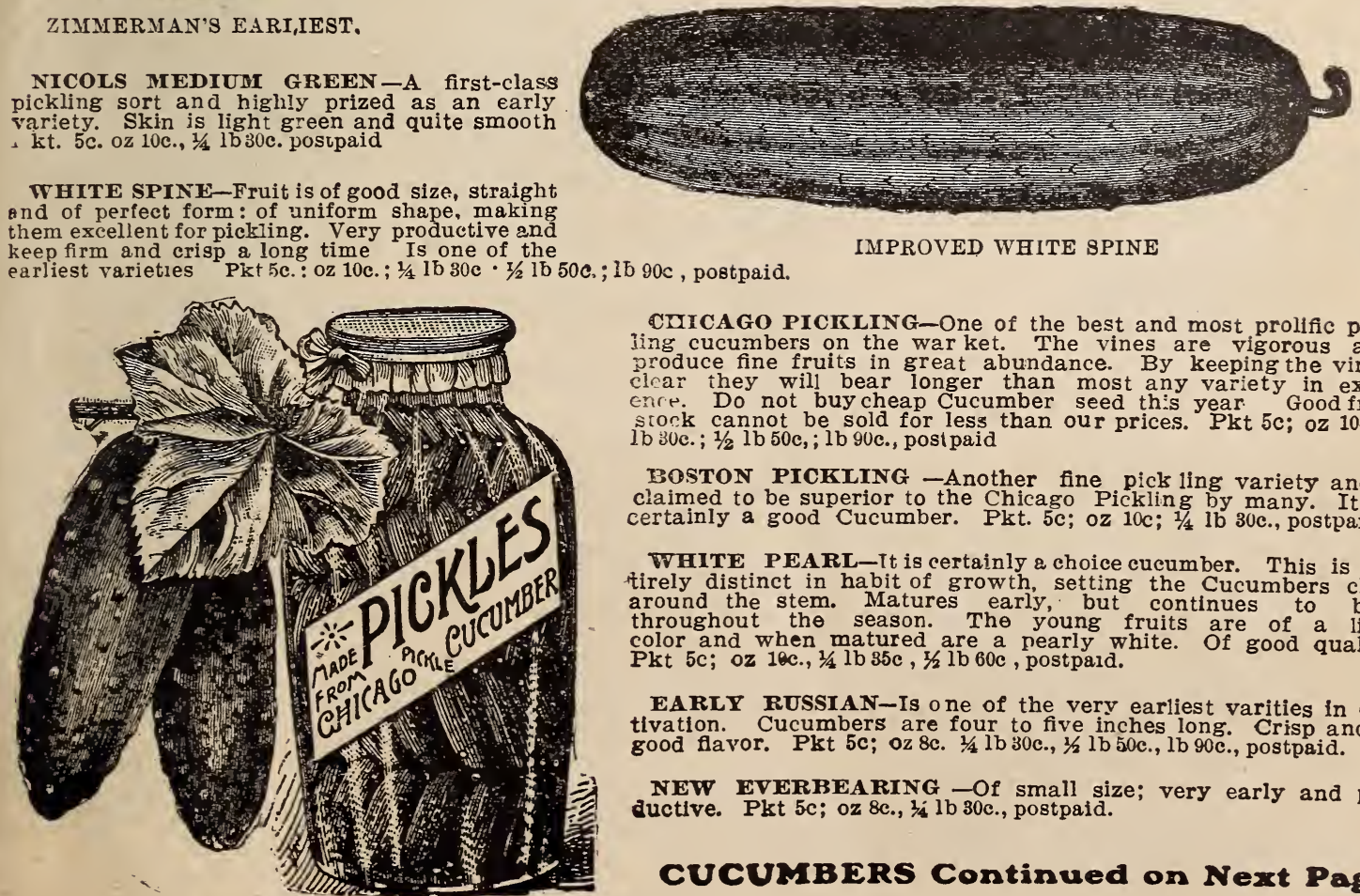

IMPROVED WHITE SPINE

CIICAGo PICKLING-One of the best and most prolific pickling cucumbers on the war ket. The vines are vigorous and produce fine fruits in great abundance. By keeping the vines clear they will bear longer than most any variety in exist enre. Do not buy cheap Cucumber seed this year Good fresh stock cannot be sold for less than our prices. Pkt 5c; oz $10 \mathrm{c}, 1 / 4$ lb 30c.; $1 / 2$ lb 50c, ; lb 90c., posipaid

BOSTON PICKLING - Another fine pick ling variety and is claimed to be superior to the Chicago Pickling by many. It is
certainly a good Cucumber. Pkt. 5c; oz 10c; $1 / 4 \mathrm{lb} 30 \mathrm{c}$., postpaid.

WHITE PEARL-It is certainly a choice cucumber. This is entirely distinct in habit of growth, setting the Cucumbers close around the stem. Matures early, but continues to bear throughout the season. The young fruits are of a light color and when matured are a pearly white. Of good quality.

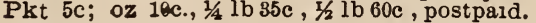

EARLY RUSSIAN-Is o ne of the very earliest varities in cultivation. Cucumbers are four to five inches long. Crisp and of good flavor. Pkt 5c; oz 8c. 1/4 lb 30c., 1/2 lb 50c., lb 90c., postpaid.

NEW EVERBEARING -Of small size; very early and pro ductive. Pkt $5 \mathrm{c}$; oz $8 \mathrm{c}$., $3 ; \mathrm{lb} 30 \mathrm{c}$., postpaid.

CUCUMBERS Continued on Next Pago. 


\section{CUCUMBERS Continued.}

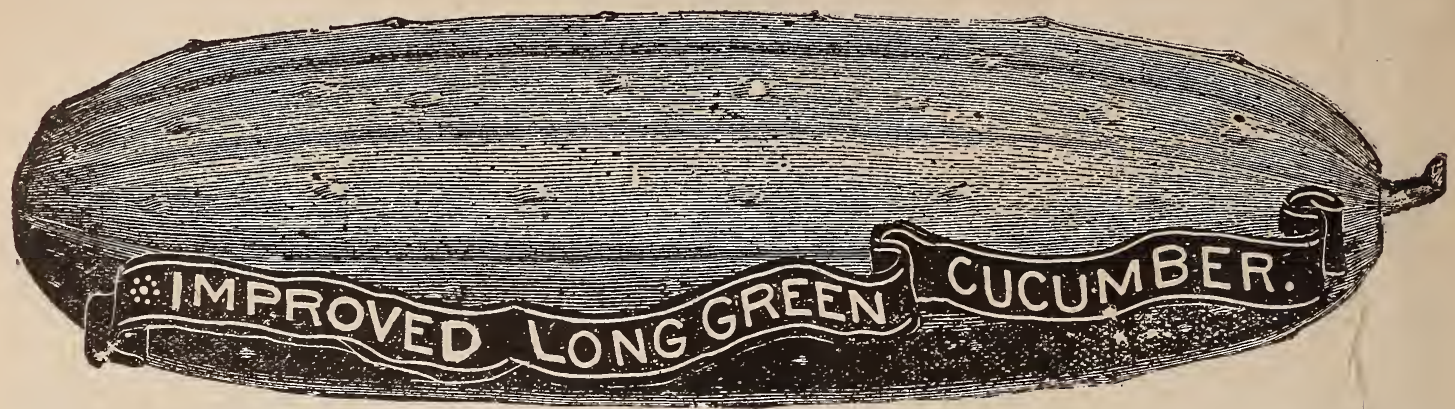

IMPROVED LONG GREEN - This is a well-known variety and very popular. Cucumbers grow from twelve to twenty inches in length. They ar'e very productive and of excellent quality. Pkt $5 \mathrm{c} ;$ oz $10 \mathrm{c} . ; 1 / 4 \mathrm{tb} 30 \mathrm{c} . ; 1 / 2 \mathrm{tb} 50 \mathrm{c}$ : it 90c., postpaid

COOL AND CRISP_A very early and prolific Cucumber. The skin is very dark green and is covered with knobs upon which the spines are placed, which gives them a very attractive appearance. As a slicing Cucumber they are excellent. Pkt 5c; 0z 10c., 1/4 1b 30c., 1/21b50c., 1b90c., postpaid.

BRTSSTTS SPROTUTS PERFECTION-Resembles miniature cabbage. Very tender, of excel2N. lent flavor and hardy. Grows a stem some two feet in height, producing sprouts about 2 inches in diameter. Pkt 5c., oz $15 \mathrm{c} ., 1 / 4 \mathrm{lb} 50 \mathrm{c}$, $1 / 21 \mathrm{~b} 90 \mathrm{c}$., $1 \mathrm{~b} \$ 1.65$, postpaid.

BROCOOI. WHITE MAMmoth-Similar to Cauliflower. Sow early in spring, transplant and cultivate BR O C. like Cabbage. Will head in Oct or Nov. Should any pl\$nts be baekward and uot ready for use before severe frost, they may be removed to a llght cellar, and will head during the wirter Pkt $5 \mathrm{c}$., oz $25 \mathrm{c}$. $1 / 4 \mathrm{lb} 90 \mathrm{c}$ postpaid.

CTI CORT, LARGE ROOTED-Used as a substitute for coffee. Of easy evilivation and should be in every gar- den. Cultivate same as Carrots : roots should be taken up in the fall, ect into small pieces and dried like apples. When wanted for use, should be roasted and ground. We would like our customers to try this as we believe you will be pleased. Pkt 5c., oz 10c., $1 / 4 \mathrm{lb} 25 \mathrm{c} . .1 / 2 \mathrm{lb} 40 \mathrm{c}, 1 \mathrm{~b} 75 \mathrm{c}$. postpaid.

COLIARDS. "EORGIA or SOUTHERN-The most satisfactory varie Largely grown in the \$onth for

TNDTVT GREEN CURLED-The best variety. Preferred to lettuce by those who have tried it. When Ieaves are ENDIVE. GREEN CURLED-The best variety. Preferred to lettuce by those who have tried it. When Ieaves are $35 \mathrm{c}, \mathrm{t} / 21 \mathrm{~b} 60 \mathrm{c}, 1 \mathrm{~b} \$ 1.10$ postpaid

GARICC. Used for flavoring soups, stews, etc. Plant in spring about 6 inches apart. the tops will die ju August and $25 \mathrm{c}$ per $1 \mathrm{~b}$.

1. The most critical Market Gardeners and Private Planters purchase therr seed of as. Everything we offer was grown especially for us, and is Fresh, Pure and of the Highest Quality.

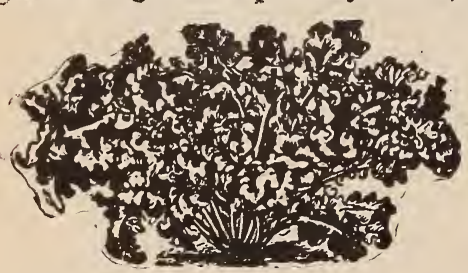

\section{BORECOLE OP KALE.}

DWARF GREEN CURLED-.-This is select stock, liradier than cabbage; leaves aro curled like parsley. Tender and of excellent flavor. Has no superior for green. Eer pkt 5c.; oz 10c, postpaid.

SIBERIAN-Low, Spreading habit; not so curly asi Dwarf Green. Per pkt 5e; $0: 100$, postpaid.

\section{Our Book, "SUCCESS WITH SEEDS." is FFwe with a One Dollar Order.}

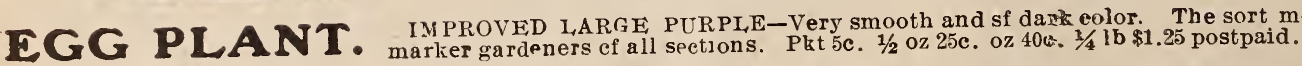

LARGE LUNDON-Is claimed to be more delicate than the onion, for soup. Sow in seed bed middle of spring GIANT SOUTHERN CURLED-Flavor sweet and pungent. Large leaves, often measuring 12 to
GIT MUSTART. GIANT SOUTHERN CURLED-Flavor Sweet and pungent. Large leaves, often meas MUTARD-Leaves are light mild and tender. Pkt 5c., oz 8c.. 1/4 10 15c., 1/2 1b 25c., $1 \mathrm{~b} 40 \mathrm{c}$. postpaid. WR MUSARD-Stronger and more pungent than the White. Pkt 5c., oz 8c., 1/4 Ib 15c., $1 / 21 b 25 c . .1 b 40 \mathrm{c}$, postpaid.

WHITE-Combines earliness, size and prolificness, Pkt 5c., 1/3 pt 12c., pt 20c., qt 35c. postpaid. By

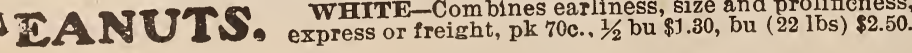

SPONGI VINE Or Dish Cloth Gourd. This old well-known Gourdivine has many wonderful things is claimed for it. While some are asking high prices, we offer choice seed at ONLY $5 \mathrm{c}$ per, pkt.

GOURDS. Very ornumental a digseful. We have the following kinds: Nest Egg--White, and makes a fine nest kinds."shapes and descriptions. 


\section{LETTUCE.}

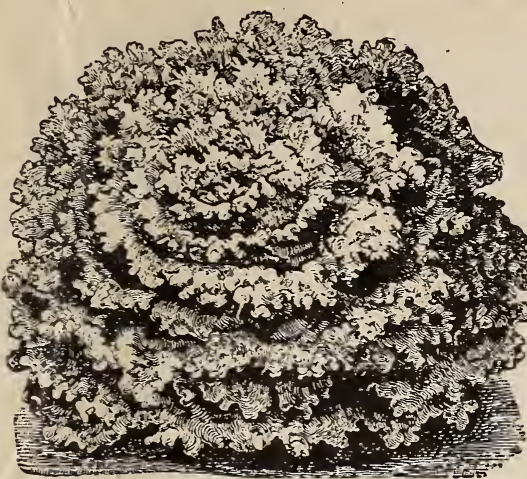

ZIMMERUAN'S EARLIEST

Our seed is fresh and can be depended upon to produce crops of the highest quality

\section{Zimmerman's Earliest.}

FARLIEST LETTUCE IN THE WORLD. CRISP AND TENDER.

Another year brings still greater words of praise for this. the EARLIEST LETTUCE IN THE WORLD. Nothing we have ever offered has given more general satisfaction than this grand variety, Tested side by sice with almost every known variety, it has always COME FIRST, with a crisp tenderness which cannot be surpassed, It is not only THE EARLIEST, but can be planted with profit the entire season. Leaves are thin, slightly curled and free from any bitterness. Another important thing to be considered is that this variety is very slow to go to seed, remaining tender a remarkably long time, Market Gardeners will find this to be a very profitable lettuce. It is as valuable fos forcing as for planting in open ground. Pkt $5 \mathrm{c}, \mathrm{oz}$ $12 \mathrm{c}, 1 / 4 \mathrm{lb} 35 \mathrm{c} ., 1 / 2 \mathrm{lb} 60 \mathrm{c}$. $1 \mathrm{~b} \$ 1.00$, postpaid.

BLACK SEEDED SIMPSON - The most popular market gardener's lettuce. Very early and forms a compact mass of loose leaves which are large, th:n and very tender; far superior to the Early Curled. Is one of the best for forcing under glass as well as
out-door planting. Remains in condition a long time before running to seed. Pkt., 5c; oz. 10c; $1 / 4$ lb., $25 \mathrm{c}$. ;1/2 lb $45 \mathrm{c}$, postpaíd.

EARLY CURLED SIMPSON-One of the very earliest varieties A large, loose-leaved var ety. Leaves are beautifully crimped, tender and sweet; dark green in color. Pkt.; $5 \mathrm{c} ; 0 \mathrm{z} ., 10 \mathrm{c} ; 1 / 4 \mathrm{lb} ., 20 \mathrm{c} ; 1 / 21 \mathrm{~b} 35 \mathrm{c}$ post naid.

THF NET MORSE-Claimed to be even a better variety than the Black Seeded Simpson. Is of the Simpson family and resembles the Grand Rapids. Pkt., 5c; 0z. 10c; $1 / 4$ lb., 5c, postpaid.

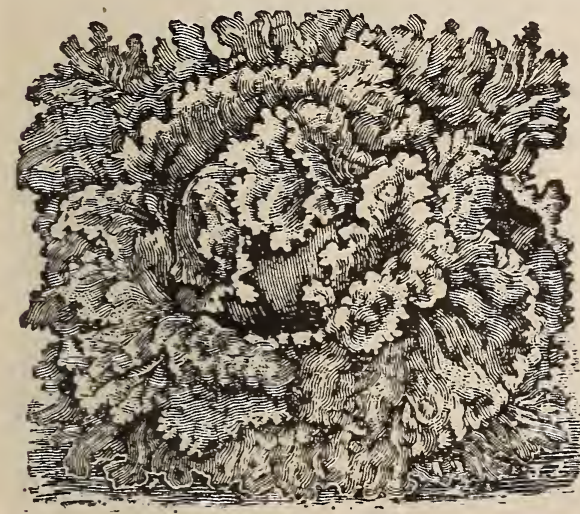

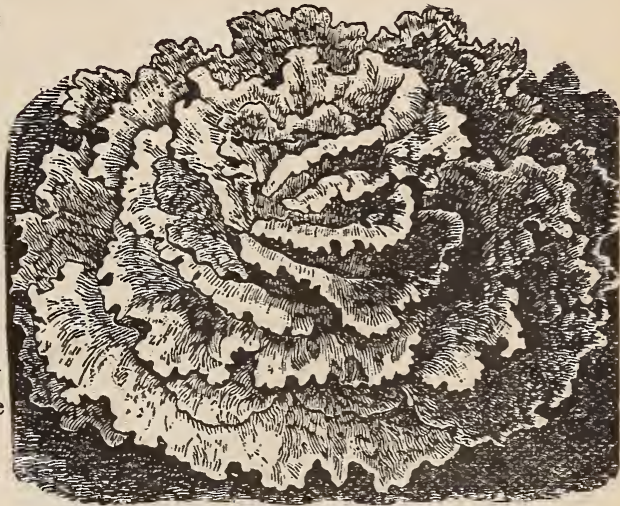

BLACK SEEDED SIMPSON.

IMPROVED HANSON - A very large, sweet, tender and crisp variety; forms large solid heads averaging scme three pounds in weight. Heads are green outside and white within. Is absolutely free from any bitterness. Unexcelled for family, garden and outdoor growth. Pkt., 5c; oz., 10c; 1/4 1b., 25c., 1/2 lb 40c postpaid.

CALIFORNIA CREAMT BUTTER-One of the best of the Butter Head varieties. The outer leaves are marked with small brown spots; center is a beautiful cream yellow. They are crisp, tender, have a rich, buttery flavor and are very ornamental. The heads are of good size and so very solid they $25 \mathrm{c}$, postpaid.

GRAND RAPIDS-This is a loose-leaved variety of strong growth. Requires less attention than the Black Seeded Simpson and will stand longer after maturity, thus making a good seller. Is of upright habit and handsome appearance; leaves thin, light yellowish green, beautifully crimped and blistered. Pkt., 5c; $9 z$. , $10 \mathrm{c} ; 1 / 1 \mathrm{lb}$., $25 \mathrm{c}$, postpald.

IMPROVED HANSON.

ICEBERG - This new variety cannot be surpassed. It forms a solid head of great beauty; the outside leaves are bright green and beautifully curled. The leaves are always crisp and tender either in early spring or hottest summer. The solidity of the head is insured by the white main ribs curving strongly to the center, which is always thoroughly blanched. There is no more superior lettuce to be had. My stock is the very best. being carefully selected crop of 1902. Pkt., 5c; oz., 8c; 1/4 lb., 20c, 1/2 lb 35̃c, postpaid.

EARLY PRIZE HEAD-Produces large loose heads of beautifully crimped and fringed leaves, exceedingly sweet, crisp and tender. A fine home garden lettuce of the loose variety. Pkt., 5c; oz. $8 \mathrm{c} ; 1 / 4 \mathrm{lb}$., $20 \mathrm{c}$, postpaid.

DENVER MARKET-An early head lettuce either for forcing or spen ground. The leaves resemble Savoy Cabbage, being beautifully marked and blistered. It is very slow to go to seed. Pkt., 5c; oz., 8c; $1 / 4 / \mathrm{lb} ., 20 \mathrm{c}$, postpaid.

HARD HEAD-A ready grower; heads hard and firm. Pkt., 5c; oz.. 8c; $1 / 4$ lb., 20c, postpais.

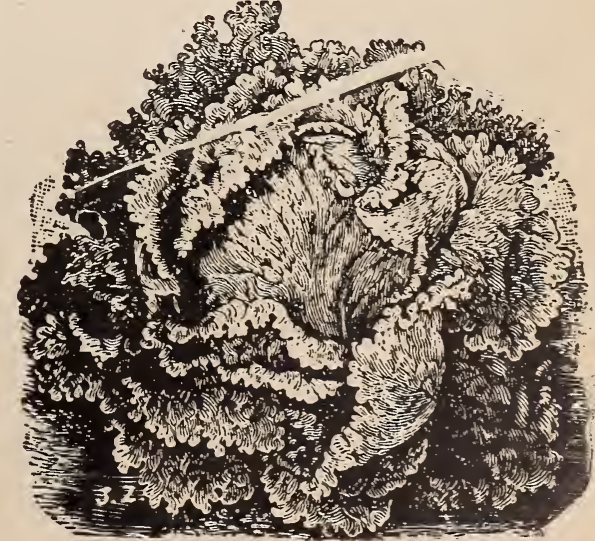

NEW ICEBERG. 

perienced melon seed growers, and is selected from choice melons only. You will find our seed of the highest quality and FresH.

\section{Zimmerman's Earliest Largé.}

NEW IARLIEST IARGF-We have here the Earliest Musk Melon grown. It is not only the very earliest, but is a melon of superior quality and good size and is therefore different Irom the majority of early varieties, surpassing them all in Earliness, Size, Productiveness, Flavor, Keeping and Shipping qualities. The melons are of uniform large size. very delicious and are fast sellers.; The flesh is a rich orange color with small seed cavity and the flavor is excellent. Nothing is more delicious than a good early musk melon and our Earliest Large pleases all who plant it, while its extreme earliness and large size makes it a desirable melon both for home and market use, Pkt 5c.; oz 10c.; $1 / 41 \mathrm{~b} \mathrm{30c,;} \mathrm{1/2} \mathrm{lb} \mathrm{50c.} \mathrm{;} \mathrm{lb} \mathrm{90c,} \mathrm{postpaid,}$

EWTRA EARLT HACKENSACK-Is a very popular market melon. It is ist ten days earlier than the ordinary strain of Hackensack, at the same time retaining all the good qualities of the old strain. It is very prod

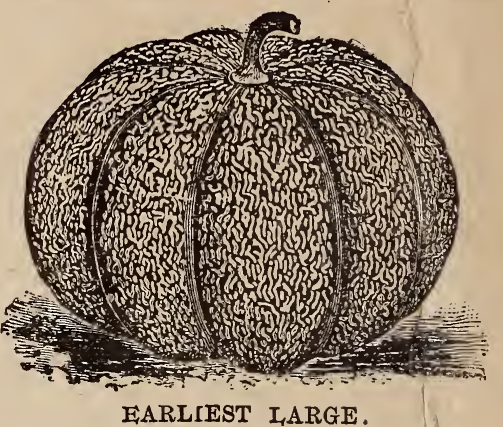

\section{Timmerman's}

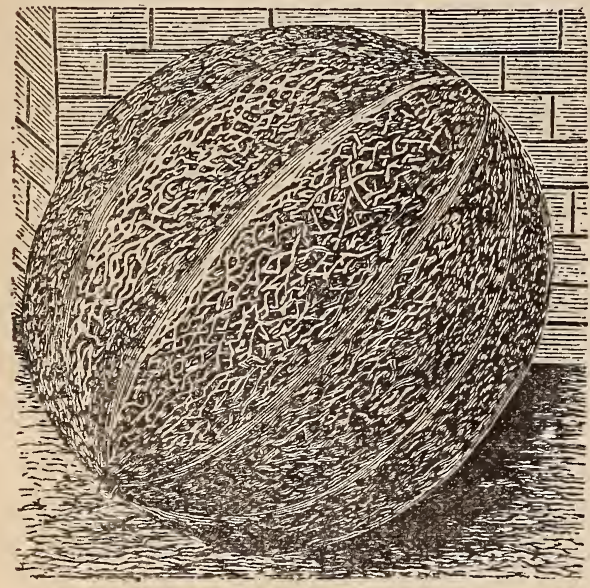

\section{GENUINE ROCKYFORD.}

\section{Seed Grown under Special Contract at Rocky Ford, Colo.}

The standard of excellence and the most popular relon on the market. Leading market gardeners send to us every season for seed of this variety, rather than save their own seed, because they know that our seed, saved from carefully selected melons of uniform size, will produce the very finest melons Our Rucky Ford seed is planted in every state and territory where melons can be grown, and we have NEVER RECEIVEd A SINGLE COMPLAINT. Rocky Fords are of medium size, even, nearly round, finely netted and the best of shippers As to quality; they can hardly be surpassed-flesh is tender, flrm and of the most delicious flavor. The seed we offer is selected from choice melons only and we guarantee it to have been grown at Rocky Ford. Colo.. under special contract and shipped direct to us. If you want seed that will produce the true Rockyford melon, correct shape, size, etc, plant our select seed, which we offer at a low price, quality considered. You cannot get a better or purer quality. no matter what you pay. Pkt 5c.; oz 10c.; $1 / 41525 c$. $1 / 21 b 40 \mathrm{c} \cdot 1 \mathrm{~b} 70 \mathrm{c}$, postpaid.

ROCKYFORD MELON

EXTRA EARLY GRAND RAPIDS-This is an extra early, yellow fleshed melon of average quality. It is claimed by many to be the very earliest musk melon in existence and is largely planted by gardeners and others who desire early melons. The meions are of handsome appearance, nearly round and finely netted and immediately attract attention in the early market. p: $:=n 71$ c., $1 / 4$ ib 25c., $1 / 2$ lb $40 \mathrm{c}$, , lb 7 ce , postpaid.

\section{Oklahoma Melon.}

This fine melon is proving a winner, especially in the South-west, It is one of the finest shippers; in flavor. it is simply luscious and can hardly be excelled, and it is claimed to be almost blight-proof, surpassing all other melons in this feature, Similar to the Rockyford. but of much larger size. Pkt 5c.; oz 1oc.; $1 / 4$ lb 25c.; $1 / 2$ lb 45c.; $1 \mathrm{~b} 85 \mathrm{c}$, postpaid.

BANANA-Is an entirely distinct variety, bearing long, slender, banana-like fruit. Skin is creamy white and entirely free from netting. Flesh a deep salmon color, thick and of fine quality. Pkt 5c.; oz $15 \mathrm{c}$. : $1 / 4 \mathrm{lb} 30 \mathrm{c}$. : $1 / 2 \mathrm{lb} 50 \mathrm{c}$; $1 \mathrm{~b} 90 \mathrm{c}$., postpaid.

\section{All Our Melon Seed} is Fresh and Pure. Plant Ours This Year.

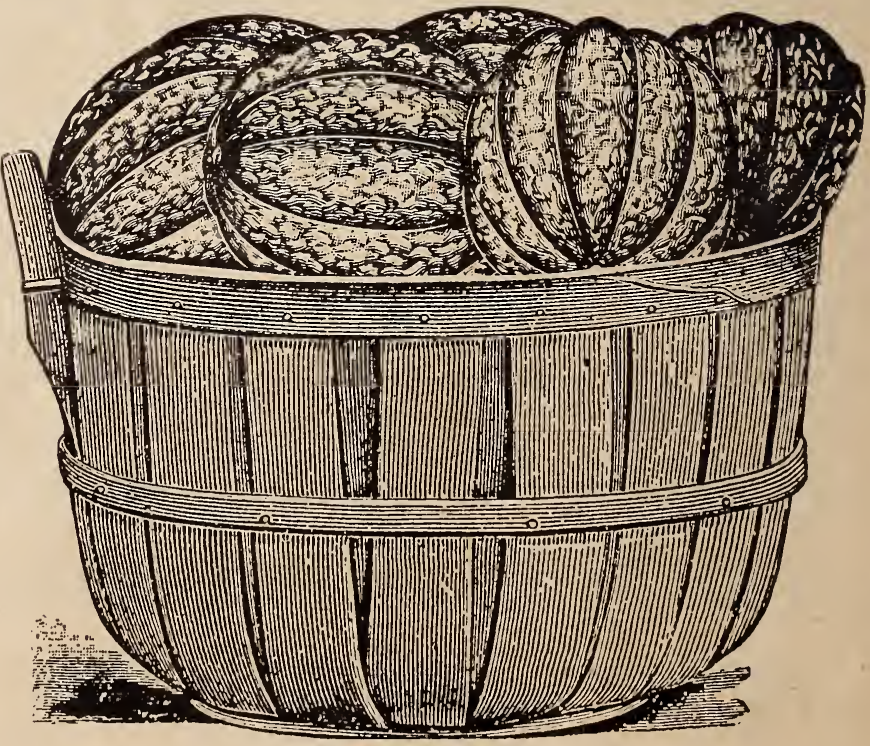

A BASKET OF OKLAHOMA'S 


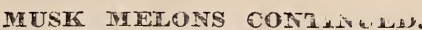

\section{"IInerman"s EXCELSIOR MUSH MELON.\&}

The Best Musk Melon Grown.

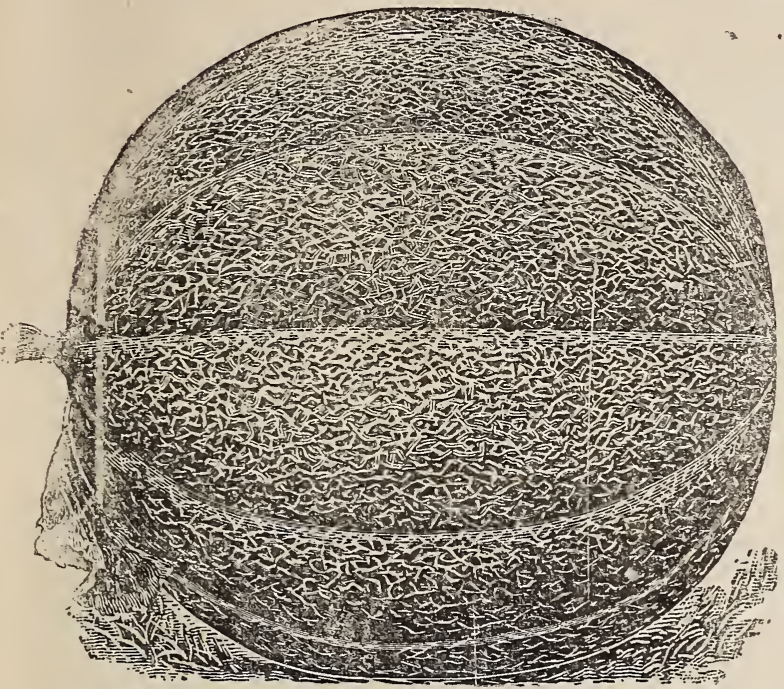

\section{Plant The EXCEISIOR.}

The have hern a r:elon, which is certainly the granclest Musk kelosigrun, pords can describe its delicious flevor---it ts simply grand. In shape they are nearly round, 28 shown by tice illustration, of good family size, weighing from to to $8 \mathrm{lbs}$. We raised a large field of these fine melons and they were the most minform lot of melons we ever saw, almost every melon being the same shape and size. The skin is dark green 23nd finely netted, the flesh is a rich orange and edible to the very rind, in fact it is nearly all flesh, as the seed cavity is very small. The flavor cannot be excelled, it is simply delicious, it beats them all. It is medium early and so attractive and its fiavor so sweet that it will be a leader on the market. We claim it to be the finest Musk Melon you ever tasted and we want you to try them---you cant afford to miss this treat. Order a packet---5ou will be well repaid. We are always so anxious to have our customers try the NEw good things we offer, that we NEVER put up the strong plea of its superior qualities, arge our customers to try it and THEN pui a high price on it, like some do. No Pink or Yellow pages filled with so-called "novelties at $15 \mathrm{c}$ nnd 25c a packet, in our bcok. We'll treat you right. This is a grand melon--a better was never offered. Vie want you to try it this year, and the price is simply: Pkt 5c.; oz 15c.: 1/4 lb 30c, postpaid,

EMERALD GEMI - A very fine varidty. Flesh is thick, of a delicate salmon color and very sweet. Pkt 5c., oz 10c,. 1/2 lb 30c., 1/2 lb 50c., lb 90c. postpaid.

OSAGE-One of the best melons grown. Very luscions and sweet a good keeper and most excellent shipper. The flesh is of salmon color and very juicy and sweet. Pkt., 5c; oz.. 8c.;1/4 lb $35 \mathrm{c}$.; $1 / 2 \mathrm{lb} 40 \mathrm{c}$.; ib 7 כ̃e, postpaid.

MILLERS CPEAM - A strong grower and very productive: rind hin and slightly netted. A sweet, tender variety and very popular. Plat 5c., oz 8c., 1/4 lb 25c., 1/2 Jb 40c., lb 75c, po $\mathrm{d}$.
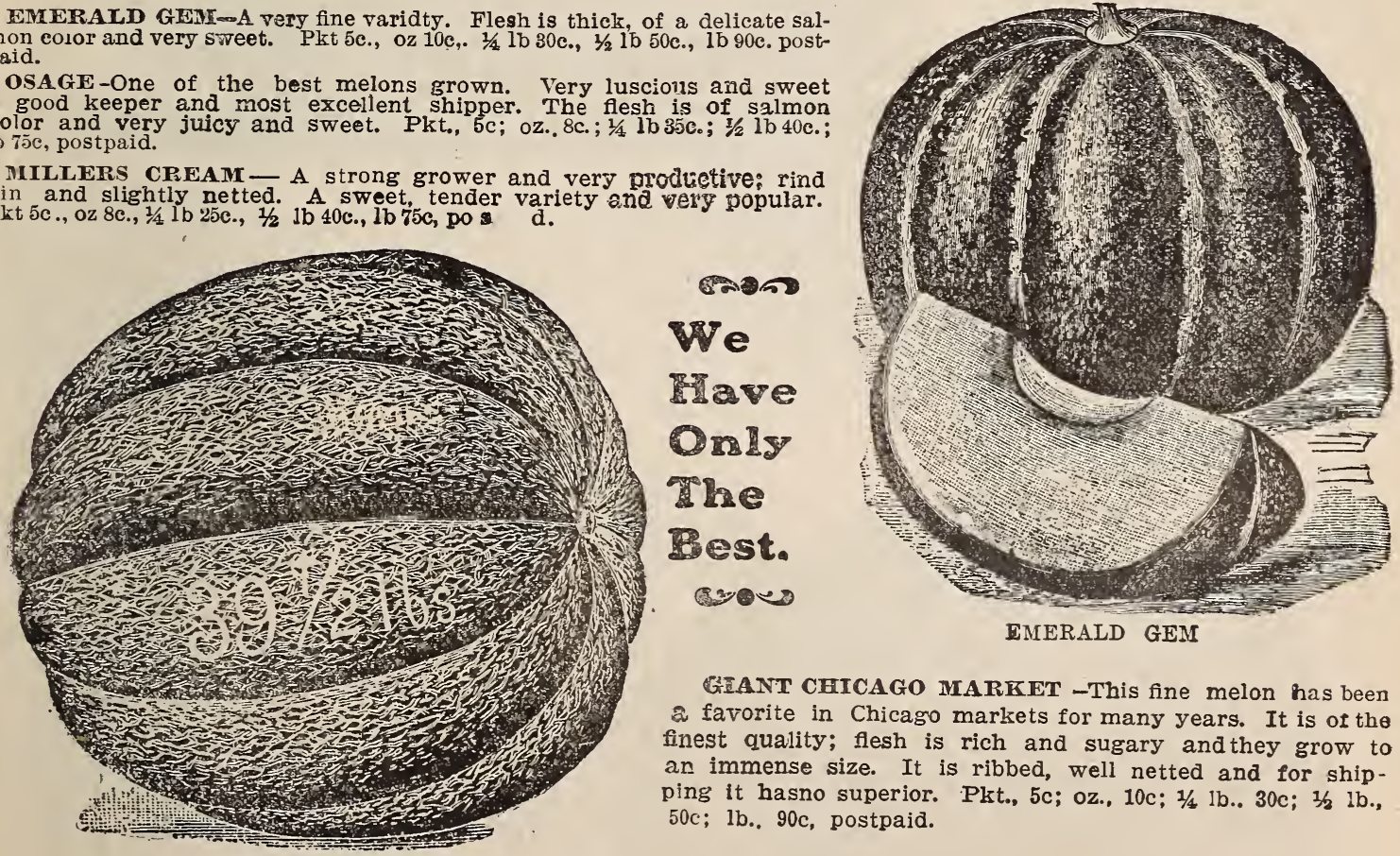

GANT CHICAGO MARKET - This fine melon has been a favorite in Chicago markets for many years. It is of the finest quality; flesh is rich and sugary and they grow to an immense size. It is ribbed, well netted and for shipping it hasno superior. Pkt., $5 \mathrm{c}$; oz., 10c; $1 / 41 \mathrm{~b} . .30 \mathrm{c} ; 1 / 2 \mathrm{lb}$., $50 \mathrm{c} ; 1 \mathrm{~b} ., 90 \mathrm{c}$, postpaid.

MONTREAL MARKET.

\section{Improved Montreal Market Musk Melon.}

The Largest of all Musk Molons.

$\Delta$ verage weight from 25 to 50 lbs. Shin is green and strongly netted; flesh is thlck, of light green color and delicste flaror. The melons are of large, round size and $1 \mathrm{mmediately} \mathrm{attract} \mathrm{attention} \mathrm{in} \mathrm{any} \mathrm{market.} \mathrm{A} \mathrm{wonderfully} \mathrm{st} \mathrm{pong} \mathrm{producer} \mathrm{and} \mathrm{gives}$ satistaction whereve $f$ grown. If you wish the largest Musk Melons of fine quality, plant our select irain of Montreal Masket. and 6c., $0210 \mathrm{c} ., 1 / 4 \mathrm{lb} 25 \mathrm{c} ., 1 / 2 \mathrm{lb} 40 \mathrm{c} . .1 \mathrm{~b} 75 \mathrm{c}$., postizaid. 


\section{WATERMELONS.}

Nothing but the Best. Our customert are so well pleased that we very seldcm have a complaint. Our Melon seed is grown for us under special contracts, by experienced growers, and taken from carefully selected melor s.

\section{Harris' Earliest Watermelon. The Earliest, Best and Largest Early Melon Grown.}

Tested in our own fields it proved two to three weeks earlier than any other variety. Every experimental station or trial grounds that have tested the Genuine Harris melon, have, so far as we know, made the same report. Our tests have proven it so superior to all others that we no longer catalogue other Extra Early varieties. This melon will bring greater profits to the Market Gardener, because its extreme earliness and size enables you to be FIRST in the market and get the top prices. The private gardener will have the first melons of the season on his table.

When we are convinced a variety has more than ordinary merits, WE WANT THE BEST IT IS POSSIBLE TO PROCURE. So with this melon, we wanted the best and highest quality of seed. The seed we offer was grown for us under special contract, by Mr. Harris of Tenn, originator of the melon. In his letter to us, $\mathrm{Mr}$. Harris says: "The melon is oval to oblong; color is dark green with beautiful mottled grayish stripes; flesh scarlet, sweet and melting; weight 20 to 30 lbs; is good shipper, keeps well, bears all summer and sure to ripen ahead of any other variety. It has been tested by Experiments at Knoxville, Tenn. and also the Government Farms at Washington, and the officers at both places pronounce it 'THE EARLIEST OF ALL AND OF GOOD. QUALITY." Some 'cheap' seed of this variety is being offered for sale and claimed to be "just as good" as that grown by Mr. Harris. Dont you believe it---NO IMTTATION IS As GOOD AS THE originaL, and the genuine seed grown and improved by Mr. Harris produces melons earlier, larger and of superior quality. It pays to plant The Best. We have it. Pkt 5c.; oz 10c.; $1 / 4$ lb 30c.; $1 / 2$ lb 50c.; lb 90c postpaid.

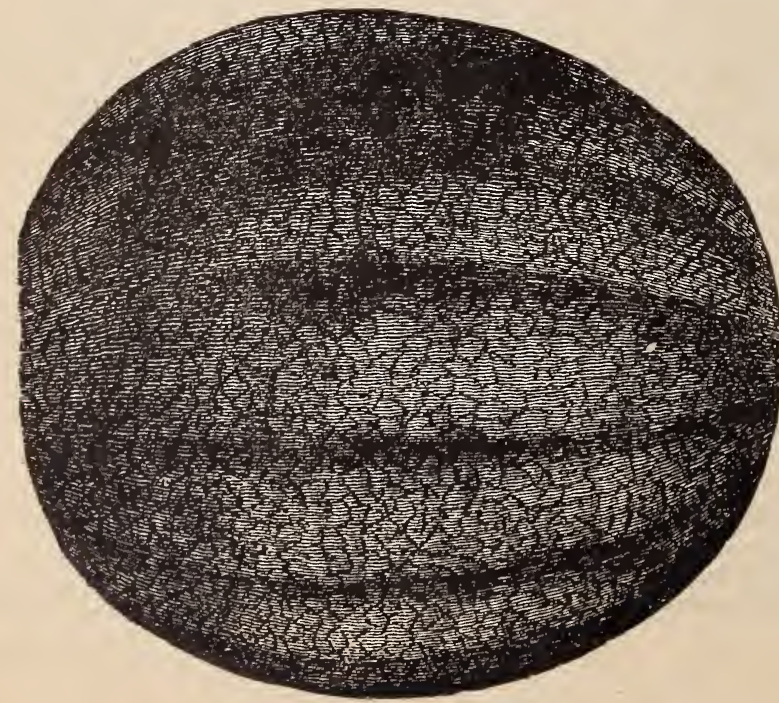

\section{Zimmerman's}

\section{Home Favorite.}

HOME FAVORITE-This is a new melon of highest quality. Our attention was called to this fine new melon while on a visit to an old melon grower. He claimed to be the originator of the melon and that it had no name. In some respects it resembles the Sweetheart, though even of finer flavor than that choice melon. We purchased the stock at once and decided to call it the Home Favorite. However, it has no sliperior as a market as well as home variety. The fruit is very large, oval; rind is dark green and thin but firm; flesh is a beautiful scarlet, tender, melting and exceedingly sweet. Give this new melon a trial this year and you will be pleased. They are of good size, early, flesh a rich bright scarlet of exceeaingly fine flavor $\mathrm{Pkt} ., 5 \mathrm{c}$; oz., 8c; $1 / 4$ lb., 20c; $1 / 2$ lb., 35c; 1b., 60c, postpaid. 


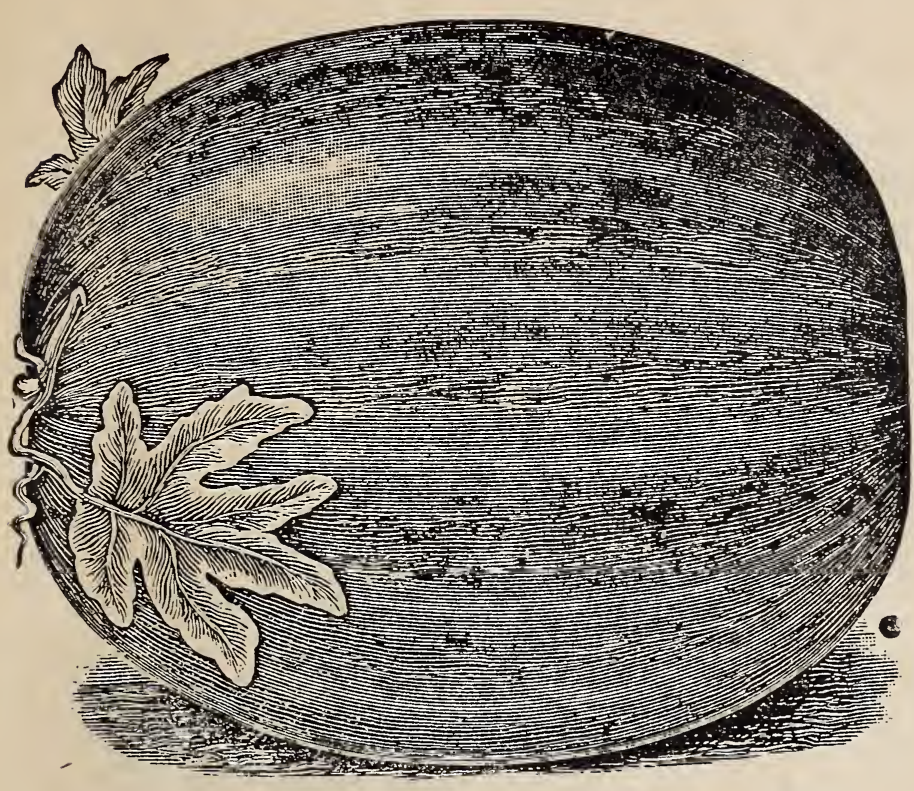

Black Diamond.

As sweet as the old Sw theart and as fine a shipper as Kolbs Gem. It is extremely prolific, surpassing almost any other melon. An acre will produce several thousand of these grand melons ranging in weight from 60 to $90 \mathrm{lbs}$ each We offer true genuine Black Diamond seed. Pkt 5c., oz 8c., 1/4 1b 20c., 1/2 lb 35c., Ib 50c, postpaid.

GEORGIA RATTLESNAKE-One of the largest melons grown and is an old favorite. Long, smooth and striped with light wavy striped. Flesh bright scarlet and of fine flavor. Pkt. 5c., oz 8c., $1 / 4$ lb 20c., $1 / 2$ lb 35c., lb 60c, postpaid.

PEERLESS or ICE CREAM-One of the best of water melon; solid and of good flavor. Pkt 5c., Oz 8c, , 1/4 1b 20c., 1/2 lb 30c., lb 50c., postpaid.

MAMMOTH IRONCLAD - Is one of the very largest melons grown. It resembles the Rattlesnake, but grows to a much larger size. The flesh is flne and solid and is of delicious sugary flavor. Pkt 5c., oz 8c., 1/4 lb $20 \mathrm{c}$., $1 / 2 \mathrm{lb}$ 30c., lb 50c., postpaid.

Our Melon Seed is Grown Especially for Us under Contracts and is Fresh, Pure and True to Name.

BLACK DIAMOND.

SWEETHEART-Excellent quality: heavy, uniformly mottled light and dark green. The flesh is bright red, very tender and sweet. It remains in good condition longer than any ther melon. Pkt., 5c; $0 z ., 8 c ; 1 / 4$ lb., 20c; $1 / 2$ lb., 35c; lb., 60c, postpa:d.

KENTUCKY WONDER-This is a superior melon in every way. As shown by the engraving, it is oblong in shape, skin very dark green, marbled with a lighter green; the flesh is a b sautiful deep scarlet, crisp, tender, ich and very sweet and sugary. It is an excellent keeper and fine for market as well as for home use. The average weight is 50 pounds. We recommend this as a good old - fashioned Kentucky melon. Pkt., 5c; oz., $8 \mathrm{c} ; 1 / 4$ lb., 20c; $1 / 2$ lb., 30c; lb 50c.; postpaid.

MCIVER'S SWEET-One of the very best of mclons; is iblong in shape, with light and dark green stripes. Pkt 5c., oz 10c., $1 / 4$ to $25 \mathrm{c}$., $1 / 2$ lb $40 \mathrm{c}$., to $70 \mathrm{c}$., postpaid.

JONES' JUMBO-Very large melon, perfectly round; rind green, with lighter stripes; deep red meat of lucious flavor. One of the very best varieties. Plt 5c., oz $8 \mathrm{c} . .1 / 4 \mathrm{lb} 20 \mathrm{c}, 1 / 2 \mathrm{lb}$ $35 \mathrm{c} ., \mathrm{lb} 60 \mathrm{c}$., postpaid.
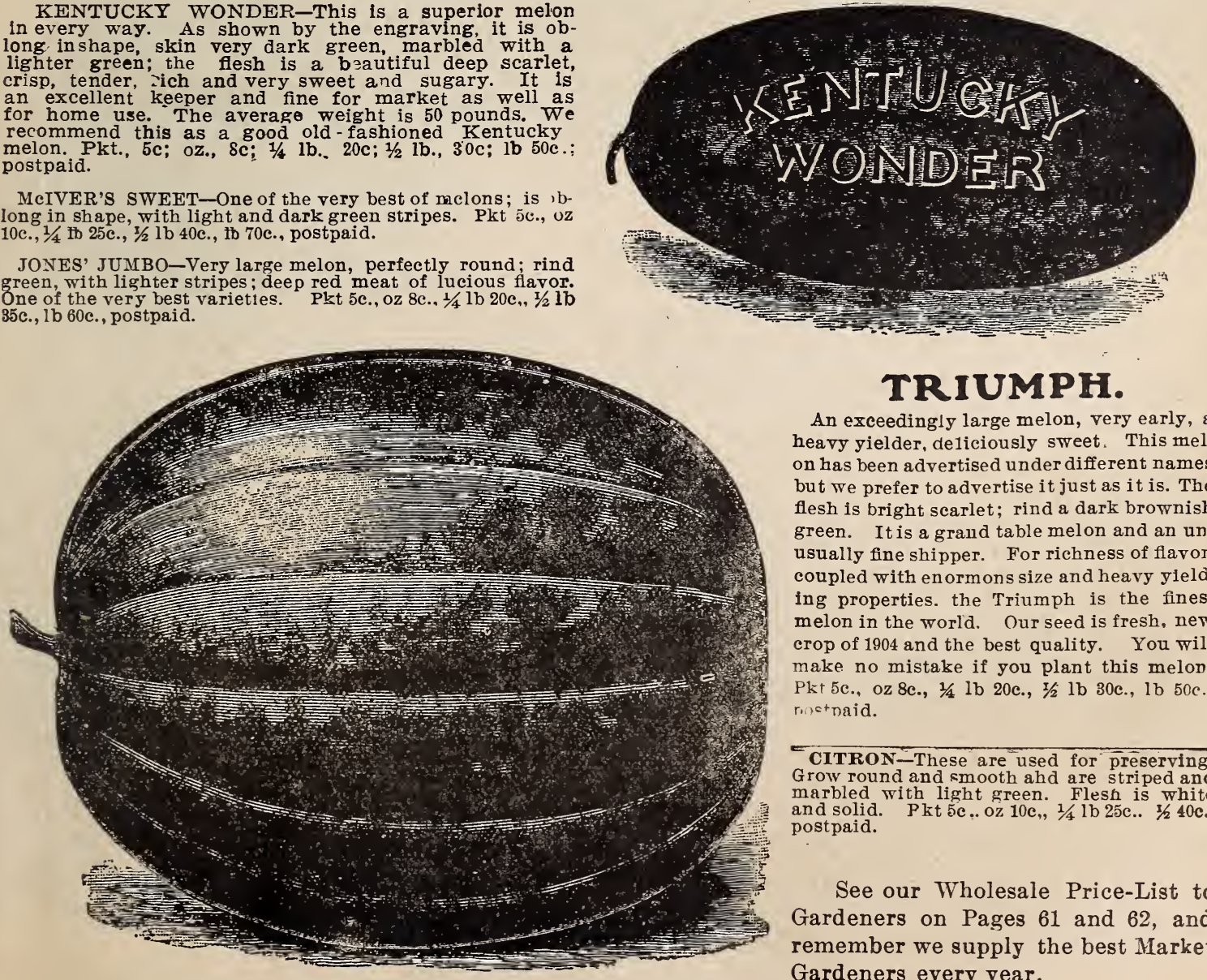

\section{TRIUMPH.}

An exceedingly large melon, very early, a heavy yielder, deliciously sweet. This melon has been advertised under different names but we prefer to advertise it just as it is. The flesh is bright scarlet; rind a dark brownish green. It is a grand table melon and an unusually fine shipper. For richness of flavor. coupled with enormons size and heavy yielding properties. the Triumph is the finest melon in the world. Our seed is fresh, new crop of 1904 and the best quality. You will make no mistake if you plant this melon Pkt 5c., oz 8c., 1/4 lb 20c., $1 / 2$ lb 30c., 1b 50c. roctnaid.

CITRON-These are used for preserving Grow round and smooth ahd are striped and marbled with light green. Flesh is white and solid. Pkt 5c.. oz 10c,, $1 / 4 \mathrm{lb} 25 \mathrm{c}$. . $3 / 240 \mathrm{c}$., postpaid.

See our Wholesale Price-List to Gardeners on Pages 61 and 62, and remember we supply the best Market 


\section{FOUR GRAND MAIN CROP MELONS.}

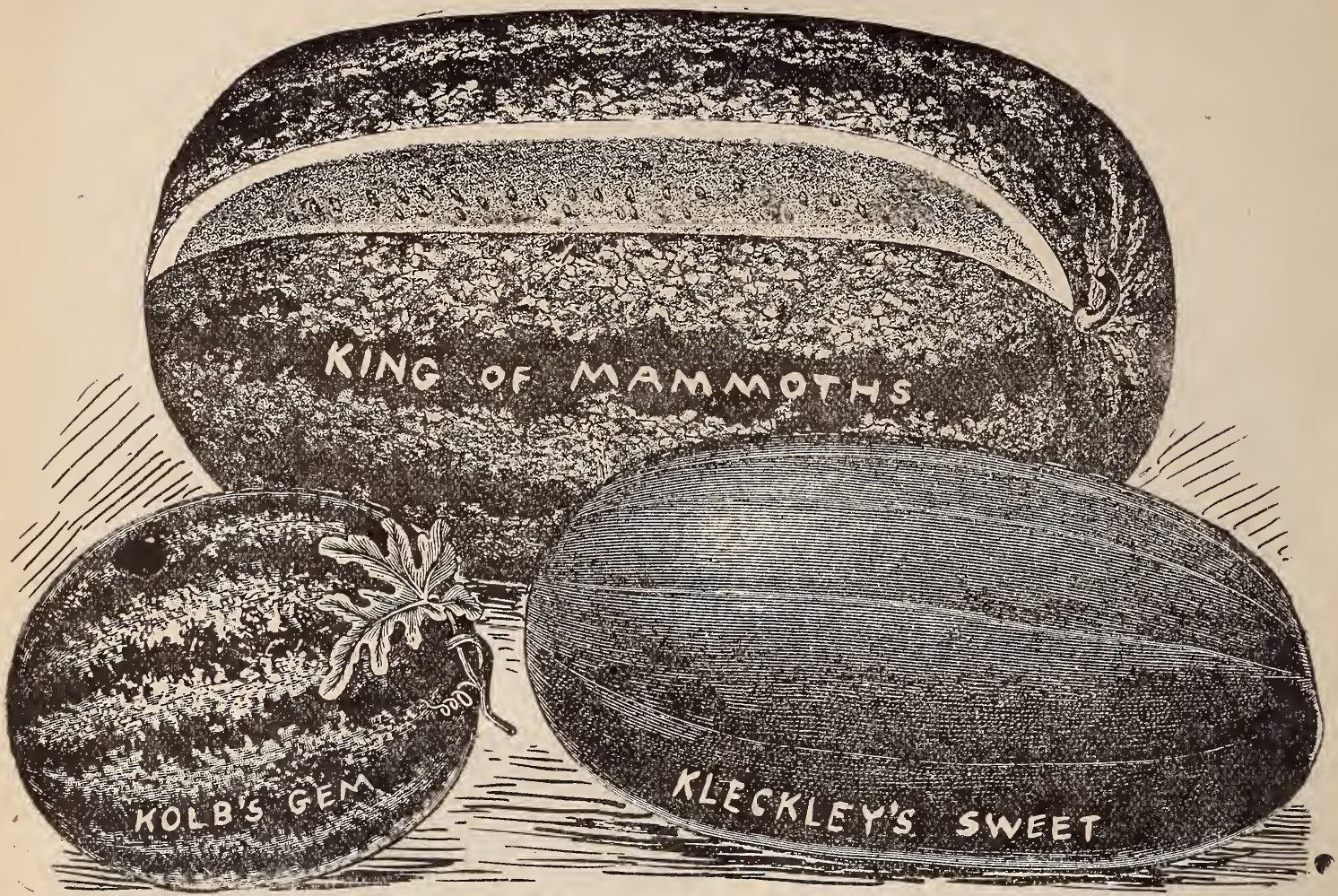

KING OF MAMMOTHS-These are the largest Water Melons in the world. The illustration given above is 8 correct one. It is a late variety of fine sweet, sugary flavor; this, with its enormous size, makes it the best of sellers. If you want a tremendous Melon of good quality, try our King of Mammoths and you will get the best and largest. Pkt 5c; oz $8 \mathrm{c} ; 1 / 4 \mathrm{lb} 20 \mathrm{c} ; 1 / 2 \mathrm{lb} 35 \mathrm{c} ; 1 \mathrm{~b} 60 \mathrm{c}$, postpaid.

KLECKLEY'S SWEET-The sweetest Water Melon in the World. Large oblong shape The skin is dark green: rind is very thin and brittle; a fully ripe Melon will always split ahead of the knife when cutting. The flesh is bright scarlet, sugary and melting in the highest degree. The heart is broad and solid. This melon is not a good shipper, because of its brittle rind, but is the finest table variety in the world and for hame market. We have the true genuine stock, which is very hard to obtain. Remember you get the pure genuine stock from us at the following prices: Pkt $5 \mathrm{c}$; oz $8 \mathrm{c}$; $1 / 4 \mathrm{lb} 20 \mathrm{c}$.; 1/2 lb 35c; lb 60c., postpaid.

IMPROVED KOLB'S GEM-This is fully a week earlier than the ordinary Kolb's Gem, besides be:ng much larger and a heavier yielder. The fruit is of large size, round, heavily mottled, with stripes of light green, which gives it an attractive appearance; flesh is bright red extending to within $1 / 2$ inch of the rind; it is a good keeper and a most excellent shipper, being firm, sweet and sugary. Our improved strain is not as coarse as the ordinary. Pkt 5c; oz $8 \mathrm{c} ; 1 / 4$ lb $18 \mathrm{c} ; 1 / 2$ lb $30 \mathrm{c} ; 1 \mathrm{~b} 50 \mathrm{c}$, postpaid.

MOUNTAIN SWEET-An old standard. Is of very large oize and of fine flavor; rind thin, and dark color. It is a grand old-fashioned melon. Pkt 5c.; oz 8c.; $1 / 41 \mathrm{lb} 20 \mathrm{c}$. : $1 / 21 \mathrm{~b} 35 \mathrm{c}$.; $1 \mathrm{~b} 60 \mathrm{c}$., postpaid.

\section{Salsify or Vegetable Oyster.}

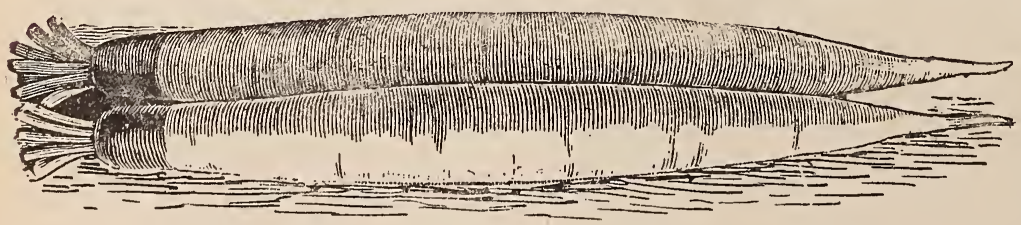

MAMMOTH SANDWICH ISLANI) -The very best variety grown. Is fully twice the size of any other variety and of better quality. The leading variety among both market and private gardeners. Pkt $5 \mathrm{c} ; \mathrm{oz}$ $10 \mathrm{c} ; 1 / 4 \mathrm{lb} 35 \mathrm{c} ; 1 / 2 \mathrm{lb} 60 \mathrm{c} ; \mathrm{lb} \$ 1.00$ post. paid. mark out the bed, mix dung and beat it down with fork to a the mark out the bed, mix dung and beat $1 \mathrm{t}$ down with fork to a thickness of 18 or 20 inches. Then allow bed to remain until then comes warm-a temperature of about 75 degrees. Devide spawn into small lumps and plant 2 inches deep, 6 inches apart; then
cover all with 2 inches light soll and protect from heavy rains. Mushrooms will appear in 4 to 6 weeks. Do not water beds unless quite dry, then use lukewarm water. 2 Price per lb brick $25 \mathrm{c} .: 3$ lbs 65c, postpaid. 


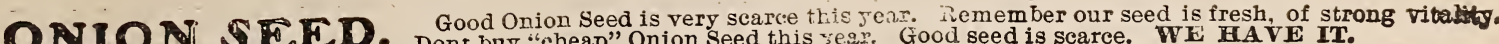

\section{Yellow Globe}

Danvers.

We offer the earliest strain of Yellow Globe Danvers. They grow of uniform large size and command the highest market price; shin is a rich golden yellow color; flesh white, mild pleasant flavor, fine grained. They are excellent keepers and the hardiest and most productive Onions in cultivation. Our seed is of excellent quality, plump and of strong vitality and you will be pleased with the crop raised and find them very profitable. Get the best. Price of our extra selected strain of Yellow Globe Danvers: Pkt., 5c; oz 10c.; $1 / 4$ lb 35c.; $1 / 2$ lb 65c.; lb $\$ 1.20$, postpaid.
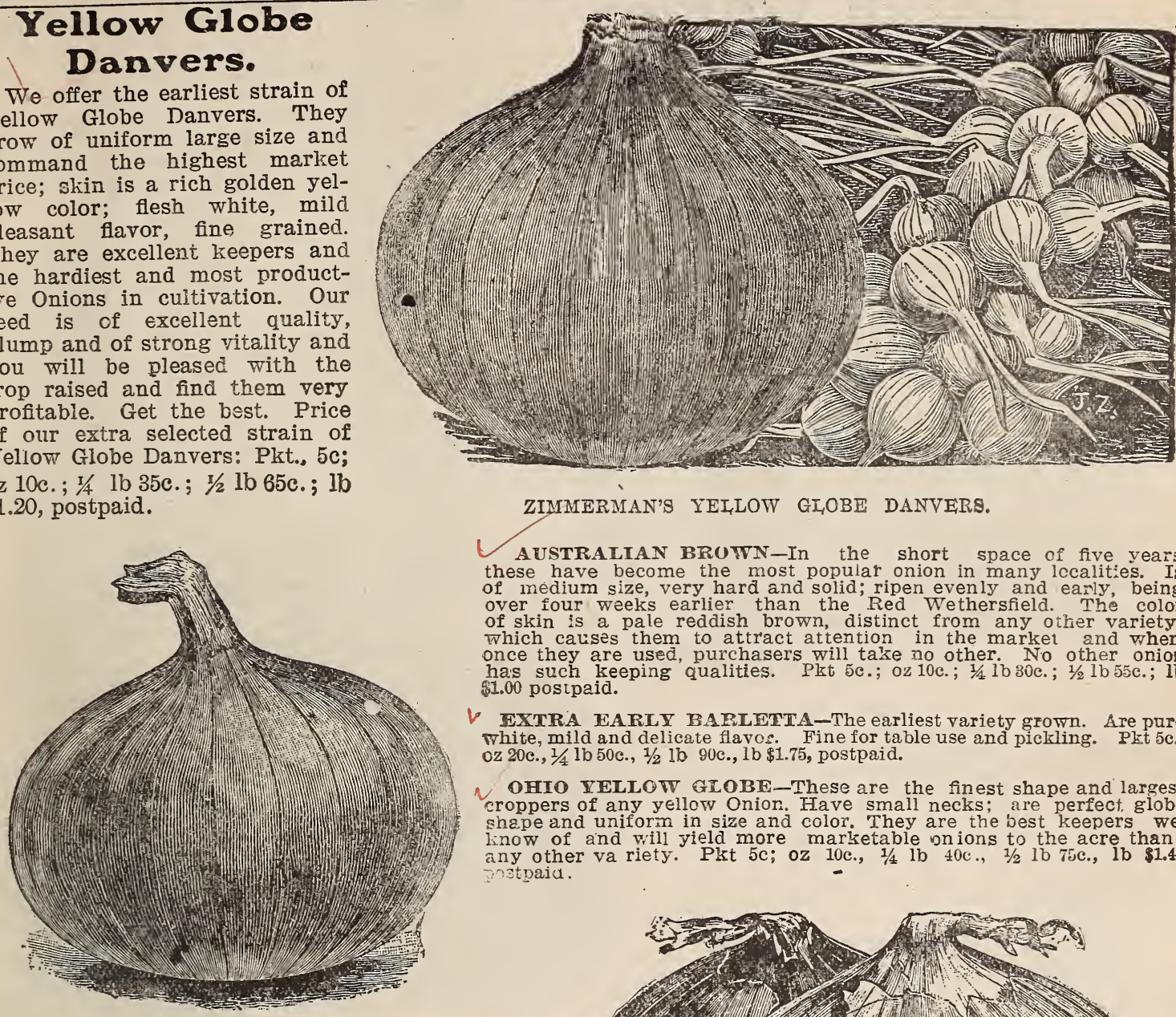

\section{ZIMMERMAN'S YELLOW GLOBE DANVERS.}

AUSTRALIAN BRUWN-In the short space of five years these have become the most popular onion in many lccalities. Is of medium size, very hard and solid; ripen evenly and early, being over four weeks earlier than the Red Wethersfield. The color of skin is a pale reddish brown, distinct from any other variety, which calses them to attract attention in the market and when once they are used, purchasers will take no other. No other onion has such keeping qualities. Pkt 5c.; oz 10c.; 1/4 lb 30c.; $1 / 21 \mathrm{~b} 55 \mathrm{c}$.; $1 \mathrm{~b}$ $\$ 1.00$ postpaid.

FXTRA EARLY BARLETTA-The earliest variety grown. Are pure white, mild and delicate flavos. Fine for table use and pickling. Pkt 5c., OZ $20 \mathrm{c} ., 1 / 4$ lb 50c., $1 / 2$ lb $90 \mathrm{c} ., 1 \mathrm{~b} \$ 1.75$, postpaid.

OHIO YELLOW GLOBE-These are the finest shape and largest croppers of any yellow Onion. Have small necks; are perfect. globe shape and uniform in size and color. They are the best keepers we lnow of and will yield more marisetable onions to the acre than any other va riety. Pkt 5c; oz 10c., $1 / 4 \mathrm{lb} 40 \mathrm{c} ., 1 / 2$ lb $75 \mathrm{c}$., lb $\$ 1.40$ ostpaia.

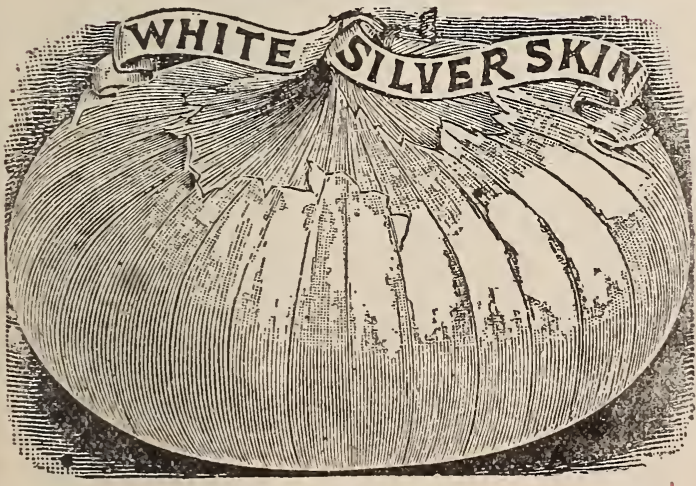

WHITE PORTUGAL or SILVER SKINA beautiful standard white onion. They grow to a good size and ripen early and eveniy. The flesh is mild, while the skin is a beau.i ful clear silvery white. glistening like silver. A favorite when young as a bunching or salad onion, but is also a good keeper and fine for fall use. An excellent variety when one or two variettes are to be planted. Pkt., 5c; oz., 15c.; $1 / 4$ lb., 50c; $1 / 2$ lb., s7c., $1 \mathrm{~b} \$ 1.50$ postpaiō.

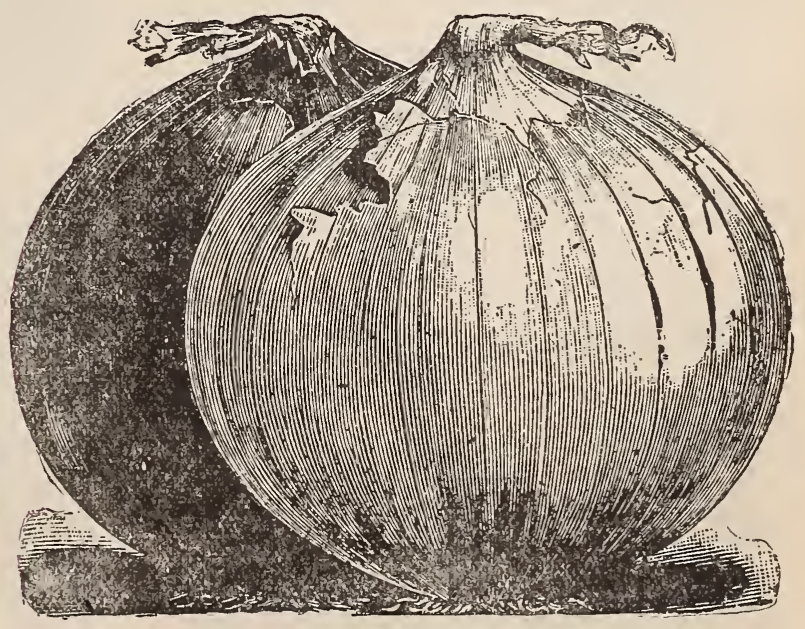

SOUTHPORT WHITE AND RED GLOBE.

SOUTHPORT RED GLORE-The same size and shape as the White Globe, but is a rich deep red in color. Pkt $5 \mathrm{c} ;$ oz $20 \mathrm{c}$. $1 / 4$ lb $50 \mathrm{c} ; 1 / 2 \mathrm{lb} 90 \mathrm{c} ; \mathrm{lb} \$ 1.50$ postpaid. We have a flne lot of choice Red Glohe sant

SOUTHPORT WHITE GLOBE-Perfectly ball-shaped: silvery white and commands the highest price in the market. The flesh is firm, fine grained, of mild flavor and a good keeper. Pkt 5c.; oz 20c.; $1 / 4 \mathrm{lb}$ $60 \mathrm{c} . ; 1 / 21 \mathrm{~b} \$ 1.00 ; 1 \mathrm{~b} \$ 1.90$, postpaid. 


\section{Largé Onions.}

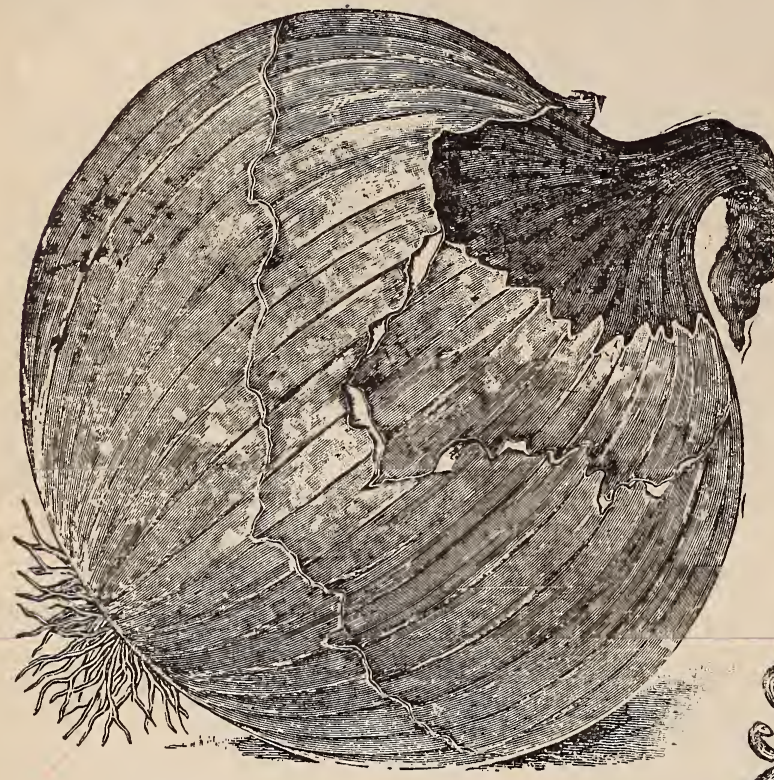

AMEP.ICAN RRIZE-TAKER.

MAMMOTH SILVER KING-This is a truly mammoth variety. No other white Onion attains such lar'e size, nor such uniform size. The average size of fuly grown Mammoth Silver King is 5 to 8 inches in diameter. The skin is a beautiful silvery white, while the flavor is so mild and sweet that it may be eaten raw like an apple, We have the true Italian seed, Pkt 5c., oz 20c, 1/4 1b50c., $1 / 2 \mathrm{lb} 90 \mathrm{c}$., lb $\$ 1.50$ postpaid.

\section{Cheap Onion Seed.}

In comparing our prices with others. please remember that WE handle nothing but the VERY BE $₹ \mathrm{~T}$. None better at a himher prine: Nane ac o ind $a^{2} n$.
AMERICAN PRIZE-TAKER-This is a hate some variety of celebrated fancy Spanish Onions which are imported in the United States and sold for from twenty-five to fifty cents each. They grow to an enormous size, specimens from our select seed have been grown to weigh $5 \frac{1}{2}$ pounds each. The flesh is pure white, fine grained, mild and delicate in flavor and present the handsomest appearance possible. Pkt 5e; oz 15c; 1/4 lb 40c; $1 / 2$ lb $75 \mathrm{c} ;$ lb $\$ 1.40$, postpaid.

LARGE RED WETHERSEIELD-You will find our stock of this famous Red Onion to be the best you have ever planted. There are some cheap seed of this variety on the market that is very inferior. but you secure ONLY THE BEST from us. The skin is a deep purplish red. flesh white and is moderately fine grained, of pleasant flavor and produces enormous crops. Pkt 5c. : oz 10c.; 1/4 1b 35c.; $1 / 2$ lb $6 \tilde{c},, 1 b \$ 1,15$ postpaid.

The Best Line of Incubators and Poultry Supplies

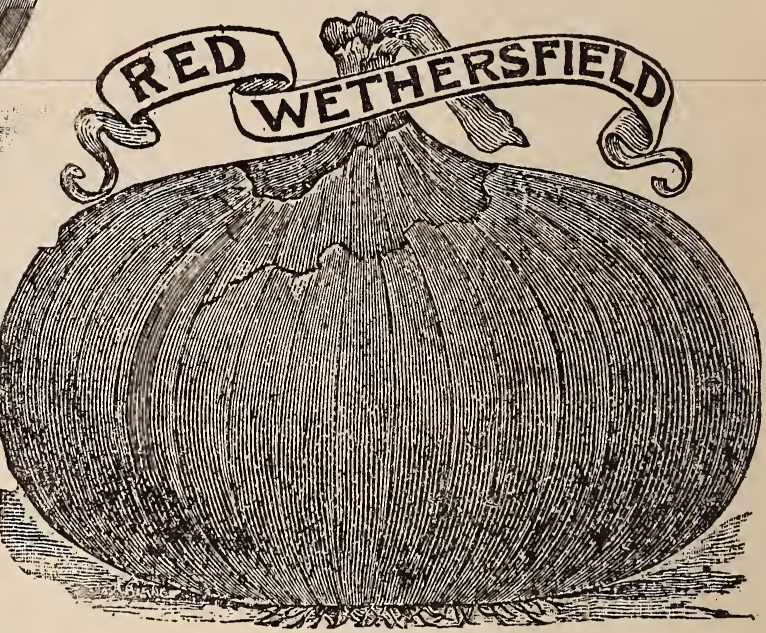

WHITE :BERMUDA ONION-(Genuineilmported Seed). Especially adapted to the Southern and South-western states and is one of the most profitakle varieties grown. They are large size, mild and easily cultivated. Our seed of this variety is as pure as can be obtained, and is direct from Teneriffe, one of the Canary Islands and the home of the Bermuda Onions. Pkt $5 \mathrm{c}$. oz $25 \mathrm{c}$., $1 / 4 \mathrm{lb} 90 \mathrm{c} ., 1 / 2 \mathrm{lb} \$ 1.60,1 \mathrm{~b} \$ 3.00$, postpaid.

\section{Zimmerman's Select Onion Sets.}

We can't be beaten on the "Onion Question" We watch it very close We have to. We have customers all over this country that look to us for their seed and they want THE BEST Ever try our seed? Do it this year and you'll come again next year just like the rest of our customers. Onion Sets are short this year, but we have a choice lot of them-barrels of them and they are just the kind to plant.

Yellow Bottom Sets-Pint 15c., Quart 25c, postpaid. By express or freight, qt 15c., 1/2 pk 50c., peck 75c, $1 / 2$ bu $\$ 1.40$, bu $\$ 2.75$.

Red Bottom Sets-Same price as the Yellow.

White Bottom Sets-Pint $15 \mathrm{c}$, , qt 30c., postpaid. By express or freight, qt 20 c., $1 / 2$ pk 60 c., peck 90 c., $1 / 2$ bu $\$ 1.60$, bu $\$ 3.00$.

\section{OIRA or GUMBO.}

WHITE VELVET-The finest variety. The pods ran be split and stored for winter soups. Pkt 5e; oz 10c, postpaid.

\section{RHUBARB.}

VICTORIA GTANT-The standard variety. It is very large, quick orowth and fine flavor. Pkt 5c; oz $12 \mathrm{c} ; 1 / 4 \mathrm{~b} 40 \mathrm{c}: 1 / 2 \mathrm{~b} 75 \mathrm{c} ; 1 \mathrm{~b} \$ 1.35$, postpaid.

\section{THE KIND TO PLANT.}

We have them. All our seeds are fresh, pure and thoroughly tested. They'll please you.

\section{SPINACH.}

NEW LONG STANDING-The best and most popular variety grown; leaves are large, thick and crumpled. It stands longer before going to seed than any other variyty. Pkt 5c; oz 6c; $1 / 41 \mathrm{~b} 12 \mathrm{c}$; $1 / 2 \mathrm{lb} 20 \mathrm{c}$; lb 35c, postpa:d. $\checkmark$ ROUND THICK LEAVED-Grows large, thick dark green leaves, slightly crumpled. Pkt $5 \mathrm{c} ;$ oz $6 \mathrm{c} ; 1 / 4 \mathrm{lb} 12 \mathrm{c}$; $1 / 2 \mathrm{lb} 20 \mathrm{c}$; lb $35 \mathrm{c}$; postage prepaid. BLOOMSDALE (Savoy Leaved)--A great favorite with-market
gardeners. Has dark, thick leaves and is perfectly hardy; flne for fall sowing. Pkt 5c., oz 6c.. 1/4"1b 12c., 1/2 1b 20c, lb 35c, postpaid. 1 PRICKLY WINTER-Will stand the severest weather with 1) Ght straw protection. Leaves are oblong or arrow-shaped. Pkt 5c.. oz $6 c_{\text {,. } 1 / 4} 1 \mathrm{~b} 12 \mathrm{c}$., $1 / 2$ ib $20 \mathrm{c}$., $1 \mathrm{~b} 35 \mathrm{c}$., postpaid. 
TS You will find our Peas to be hardy, of the highest quality and will give you perfect satisfaction, Varieties marked * are wrinkled.

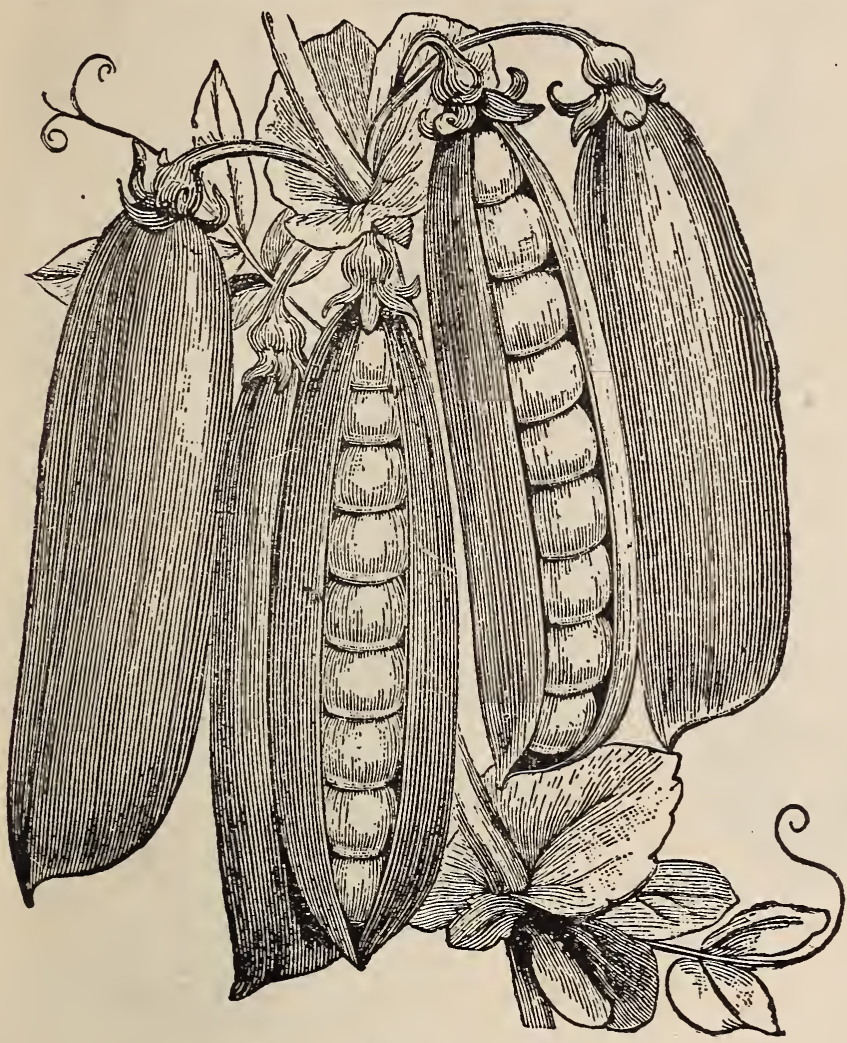

TWO WEEKS EARLY PEA.

\section{Two Weeks Early. The Earliest Pea.}

A Suro Cropper.

This is not only the Earliest Pea in cultivation, but is unequaled for yield and regularity of growth. They bear a heavy crop of well filled pods from three to three and one-half inches in length, nearly all of which can be gathered at one picking. Vines grow 18 inches in height and are loaded with these early delicious peas. Their flavor is the best and they are by far the earliest and finest early pea on the market. This pea has more than fulfilled all the claims we have made for it the past two seasons, It will make a crop where others fail and will be the first in the market. We have no report of a failure--wherever planted they have NEVER failed to bear abundantly and are THE FIRST. They are not an everbearing pea, but produce a large crop, maturino uniformly and the space can then be used for some other vegetable, before other peas are near maturing. Pkt 5c.; $1 / 2$ pt 20c.; pt 30c.; qt 50c,, postpaid. Bx eXpress or freight, qt 30c.; 4 qts $90 \mathrm{c}$.; peck $\$ 1.70$.

OLITLE GEM-(Improved Strain.) A great improvement over the old Little Gem. A improvement over the old Little Gem. A $1 / 2$ pt., 15c; pt., 25c; qt., 40c; postpaid." By express or freight not prepaid, qt.. 25c; 4 qts.. $90 \mathrm{c} ;$ pk., $\$ 1.75$.

ALASKA-Is an extra early pea; vines grow to a height of about 2 feet. The pods grow 3 inches long and are well filled with amooth, round peas of good flavor. Alaska is one of the earliest peas and quite profitable as a market and home pea. Pkt 5c., 1/2 pt 15c,. pt 25c,. qt 40c, postpaid. By express or freight, qt 25c., 4 q ts $80 \mathrm{c}$, pk $\$ 1.50$.

* GRADUS or PROSPERITY PEA-A large, pea of the finest quality and is also very early, Grows about 30 inches high, produces long pods, which are 3 to 5 inches in length and contain 8 to 10 peas. Pkt 5c., $1 / 2$ pt 20c., pt 353., qt 50c., postpaid. By express or freight, qt $35 c ., 4$ ts $\$ 1,25$, pk $\$ 2.25$.

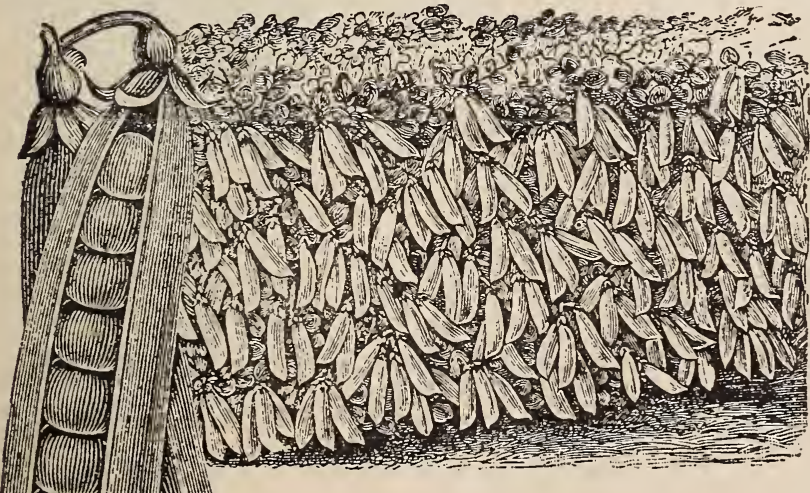

*IMP. STRATAGEM-An excellent wrinkled pea with sturdy vine, growing about 2 feet high. It is vigorous, producuive and very satisfactory. two stalks. The pods are extra large size and well filled with delicious peas. Pkt 5c., $1 / 2 \mathrm{pt}$ 15c., pt 25c., qt 40c., postpaid. By express or freight, qt $25 \mathrm{c}$. 4 qts $80 \mathrm{c}$., pk $\$ 1.50$.

*THE CHAMPION OF ENGLAND-Is a well-known late variety, very popular and is one of the best tall peas. It is far superior to the common Marrowfat, which it resembles Pkt 5c., $1 / 2$ pt $15 \mathrm{c} .$. pt $25 \mathrm{c}$. , qt 40c, postpaid. By express or freight, qt 25c , 4 qts $80 \mathrm{c} .$, peck $\$ 1.50$.

\section{*Nott's Excelsior Pea.}

This is one of the very best dwarf, wrinkled varieties in cultivation. Is hardy and vigorous and can be planted nearly as early as the smooth varieties and will mature almost as early. Ordinary cultivation quite frequently matures them in 45 days. They grow to a uniform height of about one foot, produce pods 3 inches in length, containing 7 to 9 large wrinkled peas of superior flavor and tenderness. Pkt 5 c., $1 / 2$ pt 15c., pt 30c., qt 50c, postpaid. By express or freight. qt $35 c ., 4$ qts $\$ 1.20$, peek $\$ 2.00$.

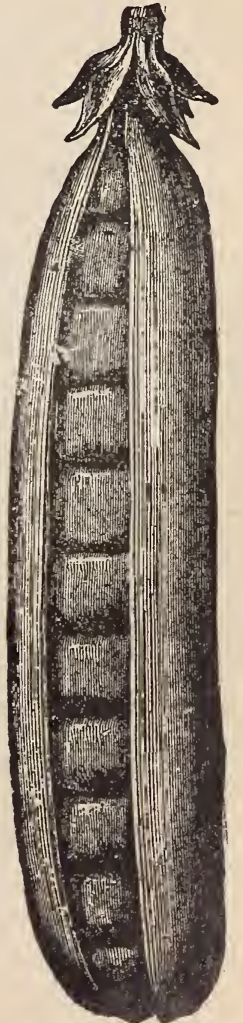




\section{Zimmerman's}

\section{*RELIANCE。}

We offered our Reliance Pea for the first time last year. Reports show it to be an exceedingly early Wrinkled Pea, maturing just after smooth peas. It may be planted as soon as the ground can be worked. Vines grow from 14 to 20 inches in height and are simply loaded with pots about three incues in length, each pod averaging 9 fine large wrinkled peas of excellent quality. They are the finest of table peas, as their flavor is simply delicious. We want you to try this grand Pea, and following our set rule of fair prices, we offer it to you at the following low prices : Large pkt $6 \mathrm{c} ; 1 / 2$ pt $15 \mathrm{c}$; pt $30 \mathrm{c}$; qt 50c, postpaid. By express or freight, qt 30c., 4 qts $\$ 1.10$, pk $\$ 2.00$.

*PRIDE OF TAE MARKET-Grows two feet high and produces large pods well is very hardy, enormously productive. It is a new pea and is giving satisfaction to all who have planted it. Large plt., 8c; $1 / 2$ pt., 15c; pt., 25c; qt., 40c, postpaid. By express or freight not prepaid, qt., $25 \mathrm{c} ; 4$ ats., $80 \mathrm{c}$; pk., $\$ 1.50$.

*TELEPHONE-This is one of the largest peas grown; vines grow from three and onelarge pods containing seven to eight peas of good size and excellent quality. With the exception of our New Mammoth. this is probably the largest variety grown. Large paid. By express or freight not prepaid, qt.,

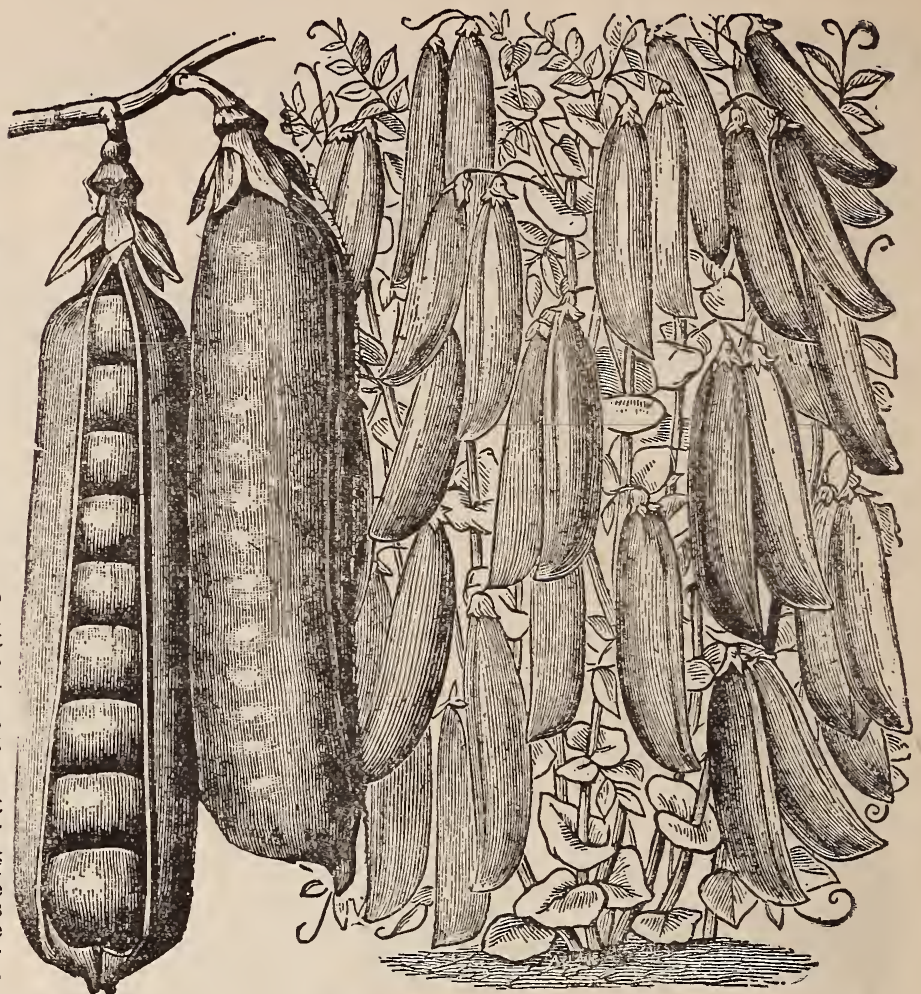

ZIMMERMAN'S RELIANCE

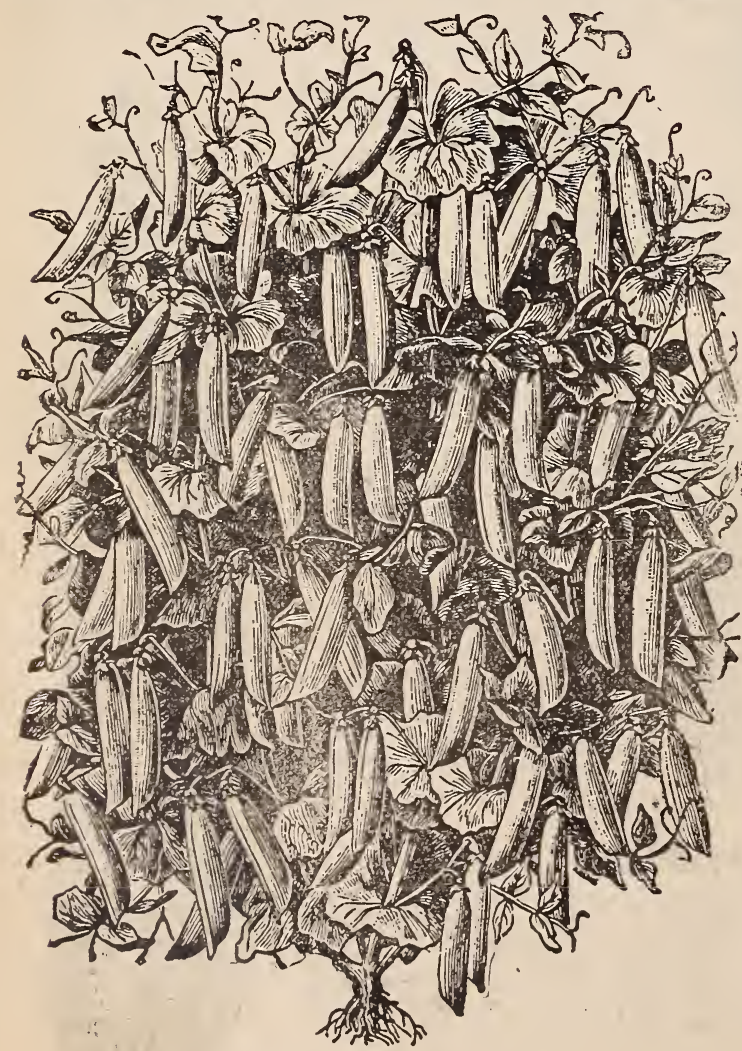

BLISS, F TERBEARING.

\section{"Zimmerman's Mammoth.}

This is a mammoth variety, the King of the Nammoths, the largest variety ever introduced It is not only the largest, but the heaviest yielder and the peas are of the finest quality. They will produce more pods to the vine and more peas to the pod than any variety we ever heard of. They grow four feet high and the yield is simply enormous. Try this srand new pea this year. Its tall, healthy vines are simply loaded with their giant pods, filled with giant peas of excellent flavor. Pkt 5c.; 1/2 pt., 20c; pt., 35c; qt., 50c, postpaid. By express or freight qt., 35c; 4 qts., $\$ 1.10 ; \mathrm{pk} ., \$ 2.00$.

*BLISS' EVIRBEARING-They grow from e'gh' en inches to two feet in height; pods are three 0 four inches long and well filler with large peas of finest quality. They bear continually throughout the season It has a peculiar branching habit forming as $h$ gh ... ten stalks from a single root stalk. We hearti, ic, ommend this variety as one that will give perfect satis. faction. Large pkt., $5 \mathrm{c}$; $1 / 2$ pt.; $12 \mathrm{c}$; pt., $20 \mathrm{c}$; qt., $35 \mathrm{c}$, postpaid. By express or freight not prepaid, at., $20 \mathrm{c} ; 4$ qts., $75 \mathrm{c}$; pk., $\$ 1.25$.

DWARF SUGAR-The best of the edible pod varieties. Large pkt., 8c; $1 / 2$ p t $^{\dagger}$ 15c; pt., $25 \mathrm{c}$; qt., 40c, postraid. By express or frelght not prepa:d, qt., 25c; 4 qts (ic; pk., $\$ 1.75$.

- YORKSHIRE HERO-As a main crop pea, this has fer equals. Its long, round pods closely filled with large peas of fine flavor. It is very produrtive and sometimes called Drart Champion of England. Pkt 5c.. 1/2 pt 12c..pt 20 c.. qt 35c., postpaid. By express or freight, qt 20c., 4 qts $75 \mathrm{c} .$, peck $\$ 1.40$.

WHITE MARROWFAT-An old standard smooth pea and very productive. Grows from 3 to 5 feet high. Pkt 5c., 1 pt $10 \mathrm{c}$. pt 15c.. qt 30c., postpaid. By express or freight, qt. $15 \mathrm{c}$. 4 qts 55 c., peck $\$ 1.00$ : 
PARSNIPS.

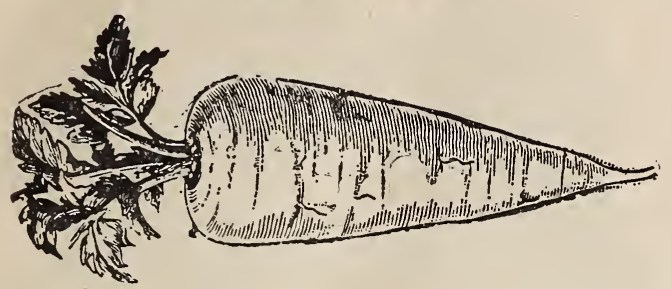

HOLLOW CROWN SUGAR or LONG SMOOTHThis is one of the oldest and best varieties in cultivation. White, sweet, tender and of excellent flavor. Pkt 5c; oz 8c; $1 / 4$ lb 15c; $1 / 21 \mathrm{~b} 25 \mathrm{c} ; 1 \mathrm{~b} 40 \mathrm{c}$, postpaid.

GUERNSEY-The Roots are short, ending abruptly with a small tap root. Grows below the surface and has smooth, clear skin. Pkt 5c; oz 8c; $1 / 4$ lb $15 \mathrm{c} ; 1 / 2 \mathrm{lb}$ $25 \mathrm{c} ; \mathrm{lb} 40 \mathrm{c}$, postpaid.

\section{Pumpkins.}

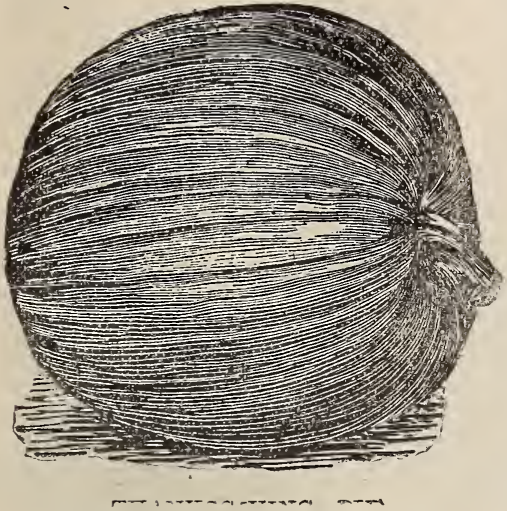

\section{PARSLEY。}

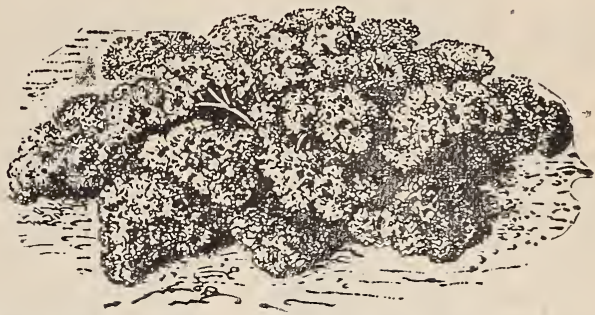

CHAMPION MOSS CURLED-An excellent vari ety; the leaves are finely curled and of a dark green color: extra fine for garnishing and culinary purposes. Pkt $5 \mathrm{c}$; $0 \mathrm{z} 8 \mathrm{c} ; 1 / \mathrm{ll} \mathrm{lb} 20 \mathrm{c} ; 1 / 2 \mathrm{lb} 35 \mathrm{c} ; \mathrm{lb} 60 \mathrm{c}$, postpaid.

NEW EMIEALD - The plants are dwarf and compact Leaves a handsome bright green, finely curled. Pkt 5c; oz $8 \mathrm{c}: 1 / 4 \mathrm{lb} 20 \mathrm{c} ; 1 / 2 \mathrm{lb} 35 \mathrm{c}$; lb $60 \mathrm{c}$, postpaid.

JAPANESE '1 and in one end, while the large neck is solid meat. They ripen early, and are very desirable as a pie or cooking pumpkin. Pkt 5c. : oz 10c.; $1 / 4 \mathrm{lb} 25 \mathrm{c} . ; 1 / 2 \mathrm{lb} 40 \mathrm{c} . ; 1 \mathrm{~b} 75 \mathrm{c} .$, postpaid.

\section{Choice Peppers. 0}

TIFE NEW MAMMOTH -The largest and finest red pepper. As large as Procopp's Giant and as mild as Ruby King. This is a new variety and one that will become very popular. The long fine fruits are of a brilliant scarlet, but will become very popular. The long fine fruits are of a briliant scarlet, but 8 inches in length and 4 to 6 inches in thickness. They are very shy seeders, which makes the seed scarce and of high price. You should certainly plani this grand new variety. Include a packet with your order. Fkt 5c., $1 / 2$ oz 15c., oz $25 \mathrm{c} ., 1 / 1 \mathrm{lb} 7$ oc., postpaid.

RUBY KING-A large red variety of handsome appearance. Grows four to six inchẻs in length and three to four :ncies through. They are so mild and sweet that they can be sliced in vinegar and eaten. Pkt 5c; $1 / 2$ oz 10c; oz $15 \mathrm{c}$ : $1 / 4$ lb $50 \mathrm{c}$, postpaid.

CELESTIAL - Plants grow to a height of two feet and bear heavily. Up to the time they are fully grown they are a rich creamy yellow, turning ${ }^{\circ}$ to a bright scarlet when ripe. This is a very useful pepper. Pkt 5c; 1/2 oz 12s; oz $20 \mathrm{c} ; 1 / 4 \mathrm{lb} 60 \mathrm{c}$, postpaid.

PROCOPP'S GIANT---This has long been the giant of the pepper family. Covered with peppers from 7 to 9 inches long and just mild enough to be pleas ant to the taste: Pkt 5c; $1 / 2$ oz $12 \mathrm{c} ;$ oz $20 \mathrm{c} ; 1 / 4$ ib $60 \mathrm{c}$. postpaid.

LONG RED CA PENNE-The old true red var:ety; fruit conical shaped, red in color and the flesh is strong and hnt. Pkt 5c: $1 / 2 \mathrm{cz} 10 \mathrm{c}$; oz $15 \mathrm{c}: 1 / 4 \mathrm{lb} 50 \mathrm{c}$, postpaid.

RED CHILI-This is the true Red Chili pepper. They are small, bright red and very hot. Pkt 5c.: $1 / 2$ oz $12 \mathrm{c} . ;$ oz 20c.; $1 / 4 \mathrm{lb}$ $60 \mathrm{c}$. postpaid.

NOTICE! Why not make up a nice order for Five Dollars or more? We'll make you our regular Wholesale prices to gardeners. See these prices on pages 61 and 62 . Why not get your neighbor to join with you? We'll give you big value for your money and treat you RIGHT. 


\section{RADISHES.}

\section{New Lightning Radish.}

Thts is indeed a Lightning Radish, for its growth and maturity is very rapid and it is the earliest variety we have been able to find. We feel that we can assure our customers that when they plant this Lightning radish, they will have early Radishes many days before others. It is a beautiful variety; dark red in color and round in shape. As tenderness is the result of rapid growth, this variety is unsurpassed in both flavor and tenderness. It is the best variety for the market gardener who wants the early trade. If you want the earliest radishes in your neighborhood, plant our New Lightning. It is the leader. We have letters from all parts of the country, telling the great success with this grand Lightning Radish. Pkt., 5c; o z., 10c; 1/4 lb., 25c; 1/2 lb., 40c; 1b., 75c, postpaid.

ROSY GEM-Is one of the very earliest varieties in cultivation. Of perfect globe shape, with deep red on top und white at bottom. Very crisp, tender and do not become hollow or pithy. Very desirable for forcing under glass Pkt 5c., oz 10c., $1 / 41 \mathrm{~b} 20 \mathrm{c}$., $1 / 2$ lb 35c., lb 50c,, postpaid.

$$
\text { - }
$$

\section{(1)}

CRIMSON GIANT-New type of radish, attaining a size more than double that of any other forcing radish, without getting hollow or pithy. Often reach 6 to 8 inches in circumference: their pure white flesh remains firm, crisp and mild despite their large size, Pkt 5c., oz 10c., $1 / 4 \mathrm{lb} 25 \mathrm{c} ., 1 / 2 \mathrm{lb} 40 \mathrm{c}$., lb 75:, postpaid.

EARLY S C A R LET GEOBE-A very early variety and good for either forcing or out-door culture. As early as Non-Plus-Ultra but one-third larger; mild, crisp, juicy and tender; is one of the best selling radishes on the market. Plet 5c; oz $10 \mathrm{c} ; 1 / 4 \mathrm{lb} 20 \mathrm{c} ; 1 / 2 \mathrm{lb}: 0 \mathrm{c} ; 1 \mathrm{~b} 50 \mathrm{c}$, postpaid.

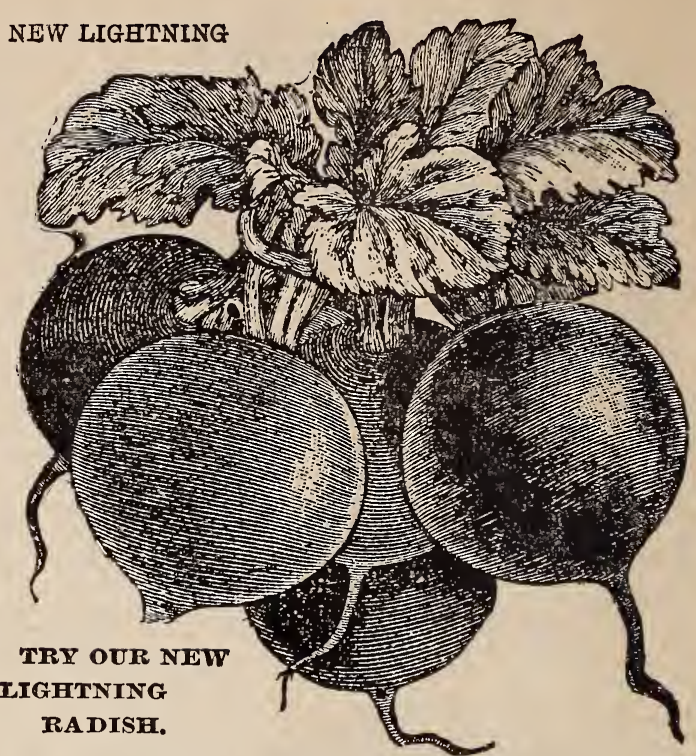

FRENCH BREAKFAST-As shown by the illustration, this is a beautiful radish; very early, bright scarlet, with white tip. It is one of the very best for family use. Pkt $5 \mathrm{c} ;$ oz 10c; $1 / 4 \mathrm{lb} 20 \mathrm{c} ; 1 / 2 \mathrm{lb} 30 \mathrm{c}$ : lb 50c,
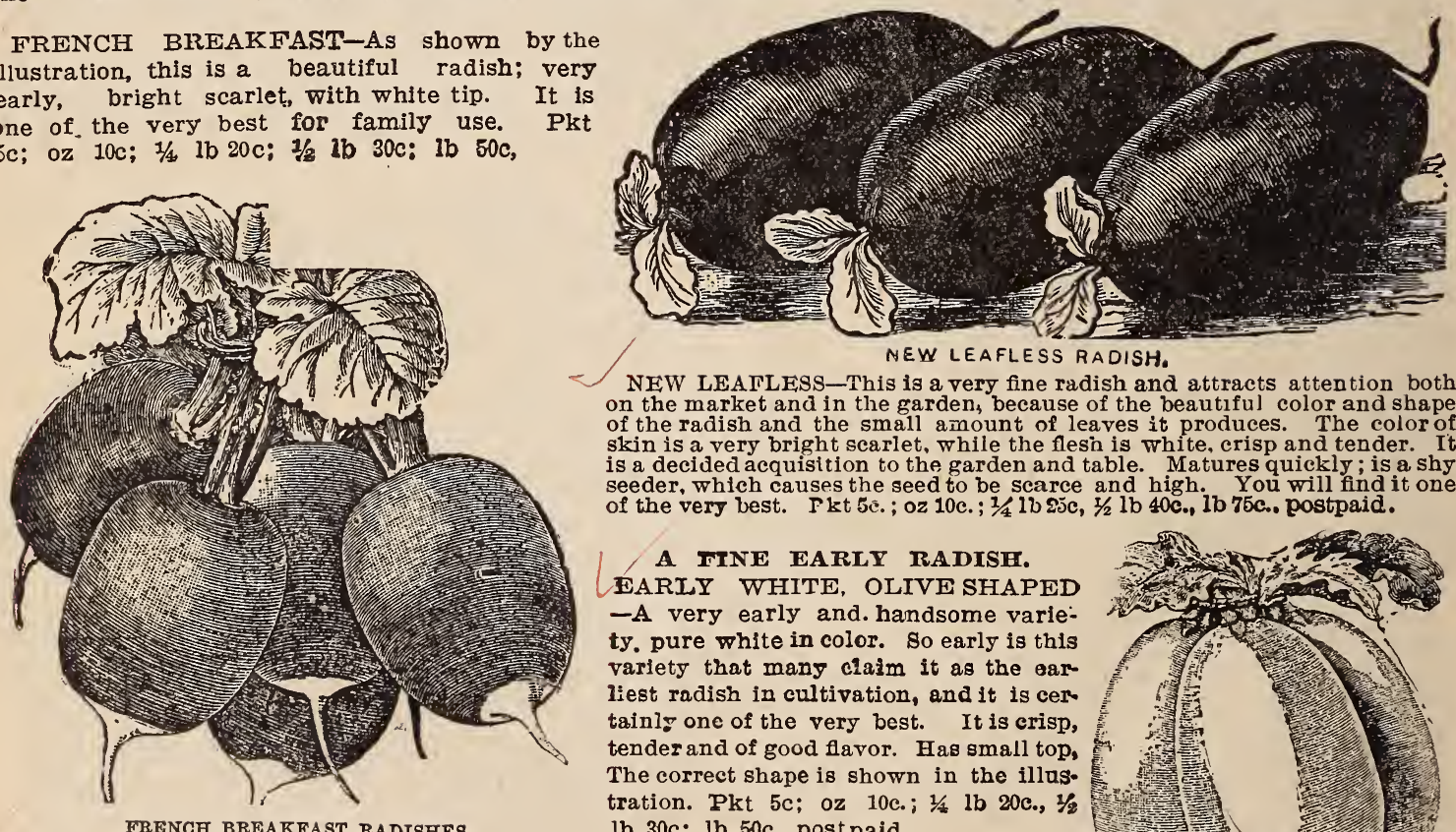

NEW LEAFLESS RADISH.

NEW LEATLESS-This is a very fine radish and attracts attention both on the market and in the garden, because of the beautiful color and shape of the radish and the small amount of leaves it produces. The color of skin is a very bright scarlet, while the flesh is white, crisp and tender. It is a decided acquisition to the garden and table. Matures quickly; is a shy seeder, which causes the seed to be scarce and high. You will find it one of the very best. Fkt 5e. ; oz 10c.; $1 / 41 \mathrm{l} 25 \mathrm{c}, 1 / 2 \mathrm{lb} 40 \mathrm{c.}$, lb 75c.. postpaid.

\section{A TINE EARLY RADISH.}

EARIM WHITE, OLIVE SHAPED -A very early and. handsome varie: ty. pure white in color. So early is this variety that many claim it as the earliest radish in cultivation, and it is cer. tainly one of the very best. It is crisp, tender and of good flavor. Has small top, The correct shape is shown in the illus. tration. Pkt 5c; oz 10c.; 1//2 lb 20c., $1 / 2$ lb $30 \mathrm{c} ; 1 \mathrm{~b} 50 \mathrm{c}$, postpaid.

BRIGHTEST NEW I.ONG CARDINAL-The WHITE STRASBURG-The roots handsomest and one of the earliest long Rad are oblong; both skin and flesh ishes. It is the brighest scarlet we have ever pure white; ilesh firm, crisp and seen and it is a fine seller and a gond home tender and retains these qualities radish. Pkt 5c; oz 10c; $1 / 4 \mathrm{lb} 18 \mathrm{c} ; 1 / 2 \mathrm{lb} 30 \mathrm{c} ; \mathrm{lb}$ even when old. Pkt 5c; oz 10c; $1 / 4$ $50 \mathrm{c}$, postpaid.

BEAR IN MIND THAT OUR SEED IS THE BEST AND NEW CROP

EARLY SCARLET TUR NIP, WHITE TIPPED-For out-door culture, this variety has no superior and has been a leading market Radish for several years. It is in great demand by the most critical growers, and we hare the finest stock. Pkt. $5 \mathrm{c} ;$ oz $10 \mathrm{c}$ : $1 / 1 / \mathrm{lb} 18 \mathrm{c}: 1 / 2$ lb $30 \mathrm{c} ; 1 \mathrm{~b} 50 \mathrm{c}$, postpaid.

ROSE CHINA WINTER-Also called Scarlet Winter. A large, fine shaped radish of half-long shape and rose colored skin; Alesh is white and mild. A good winter keeper and very showy. Pkt 5c.: oz 10c.; 1/4 1b 20c.; $1 / 21 \mathrm{~b} 35 \mathrm{c}$.: 1b 60c., postpaid. 


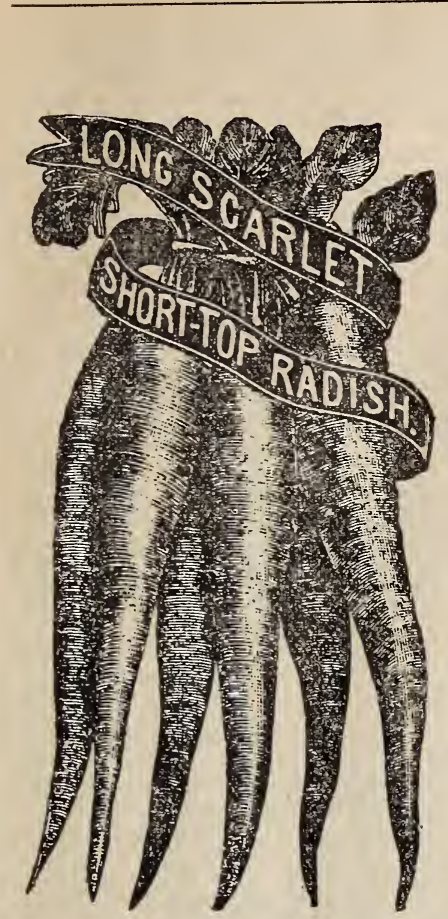

\section{Five Choice Long Radishes.}

| NEW WHITE ICICLE-Pure white, loü and slender. The earliest long white radish in cultivation and as early as the Long Scarlet Short Top and is more desirable for forcing. In the open ground, the roots remain brittle, crisp and tender a long time We hope you will give this excellent radish a trial. Pkt $5 \mathrm{c}$, oz 10c., $1 / 4$ lb 30c., $1 / 2$ lb 50c. $1 \mathrm{~b} 90 \mathrm{c}$, postpaid.

LONG SCARLET SHORT TOP The standard long variety for home and market. Roots are long, straight, smooth, rich scarlet crisp and of superior flavor. They grow seven inches long, half out of the ground. Pkt 5c; oz 10c.; $1 / 4$, lb 20c., $1 / 2 \mathrm{lb}$ $30 \mathrm{c} ; 1 \mathrm{~b} 50 \mathrm{c}$, postpaid.

LONG WHITE LADY FINGER-One of the best long white radishes and is a very popular variety. Is sweet, mild and tender. Pkt 5c., oz 10c., $1 / 4$ lb 20c., $1 / 2$ lb 35c., lb 60c, pcstpaid.

CALIFORNIA MAMMOTH WINTER A giant, white fleshed fall Radish used largely in the market of San Francis co; grows from 8 to 12 inches long; it is solid, tender Pkt $5 \mathrm{e}$; oz $10 \mathrm{c} ; 1 / 4 \mathrm{lb} 20 \mathrm{c} ; 1 / \mathrm{s}$ lb $35 \mathrm{c} ; 1 \mathrm{~b} 60 \mathrm{c}$, postpaid.

NEW WHITE CHINESE-Is sometimes called Celestial and is the finest and largest of the white radishes, growing 12 to 15 inches lung and 5 inches in diameter aud is tender.

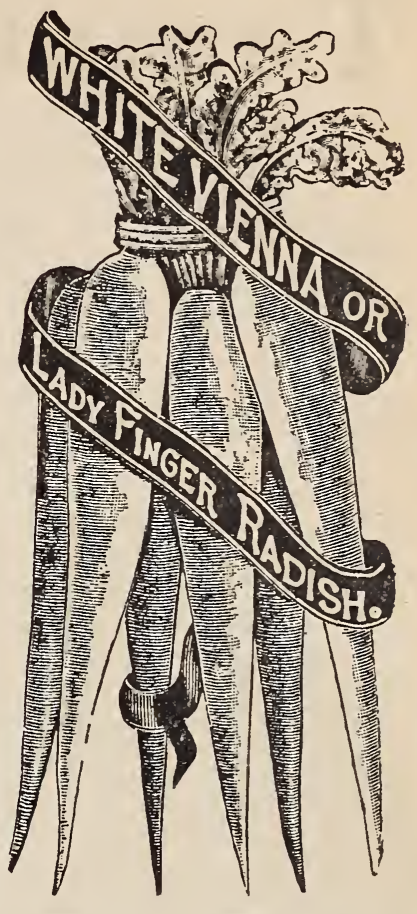

SQUASHES.

We offer the best and most popular varieties. Our seed is unsurpassed by any on the market and prices are as low as GOOD, thoroug .J tested seed can be sold.

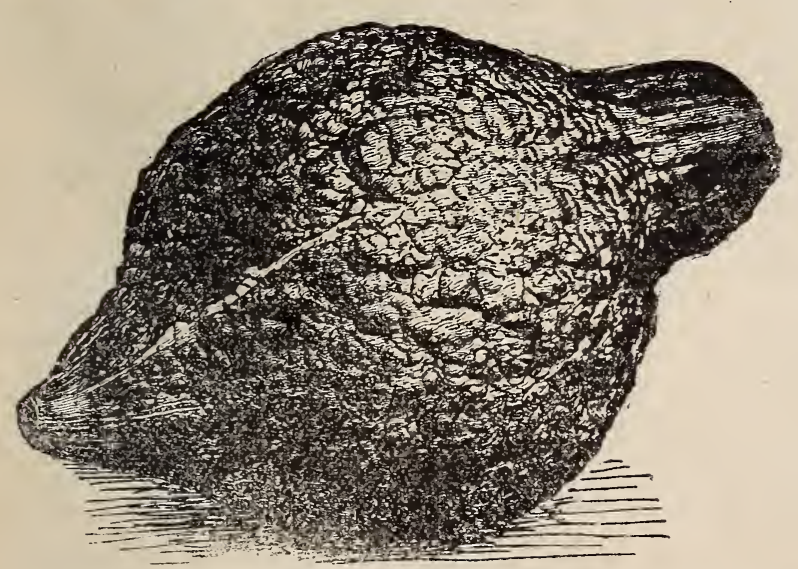

WARTY HUBBARD-This is the ideal Hubbard for home and market use. It is more largely advertised than any other variety. It is very sweet and considered superior to the other varietles by many. The longest keeper and best shipper. Pkt $5 \mathrm{c} ;$ oz $10 \mathrm{c} ; 1 / 4 \mathrm{lb} 30 \mathrm{c} ; 1 / 2 \mathrm{lb} 55 \mathrm{c}$; lb $\$ 1.00$, postpaid.

IMPROVED MAMMOTH HUBBARD-A select strain of the celebrated Hubbard Squash and noted for its immense $s$ It is more attractive than the other varieties of Hubbard Squashes on account of its large size and is the equal of the other varieties in quality. Plant some of our Improved Mammoth Hubbard seed this year. Pkt 5c; oz 10c; $1 / 4$ lb $30 \mathrm{c}$, postpaid.

GOLDEN HUBBARD-Deep orange-yellow; very attractive; fine grained, cooks well and is of superior flavor. In quality and productiveness it exceeds the old varieties. Try it. Pkt 5c; oz 10c; $1 / 4 \mathrm{lb} 30 \mathrm{c} ; 1 / 2 \mathrm{lb} 55 \mathrm{c} ; 1 \mathrm{~b} \$ 1.00$, postpaid.

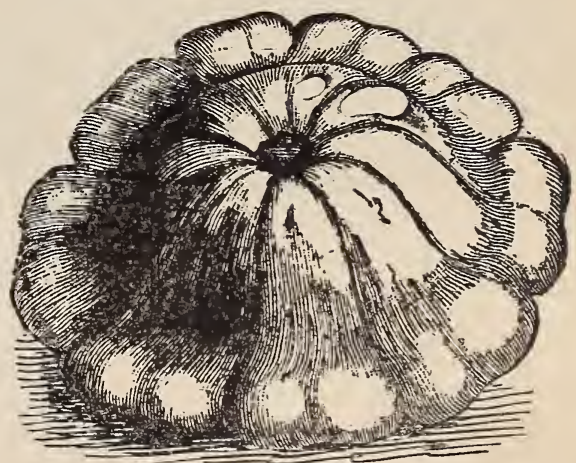

MAMNOTH WHITE BUSH SCALLOPKnown through the South as "Cymling." A beautiful clear waxy white. of fine quality Pkt $5 \mathrm{c} ;$ oz 10c; $1 / 4 \mathrm{lb} 20 \mathrm{c} ; 1 / 2 \mathrm{lb} 35 \mathrm{c} ; 1 \mathrm{~b} 75 \mathrm{c}$, postpaid.

PIKE'S PEAK or SIBLEY-Owing to the hardness of the shell this is one of the hest shippers. Skin is smooth of greenish gray color; flesh is golden orange color and very solid. Pkt $5 \mathrm{c} ;$ oz 8c; $1 / 4$ lb $25 \mathrm{c} ; 1 / 2 \mathrm{lb}$ 0c; $1 \mathrm{~b} 75 \mathrm{c}$, postpaid. SUMMER CROOKNECK-This is the best summer variety; is very early, large size and warty, which adds to its value; color is bright yellow. Pkt $5 \mathrm{c} ;$ oz 10c: $1 / 4$ lb $20 \mathrm{c} ; 1 / 2 \mathrm{lb} 35 \mathrm{c} ; 1 \mathrm{~b}$
$65 \mathrm{c}$, postpaid.

MARBLEHEAD - About the size of the Hubbard and shell of bluish-green. P

oc; $1 / 4 \mathrm{lb} 25 \mathrm{c} ; 1 / 2 \mathrm{lb} 45 \mathrm{c}$; lb $80 \mathrm{c}$, postpald.

BOSTON MARROW - Oval in form; skin bright orange and flesh yellow. Pkt 5c; oz 10c; $1 / 4$ lb 20c; 1/2 lb 35c; $1 \mathrm{~b}$ 5c, postpaid.

MAMMOTH WHALE-A new variety from France and a magnificent squash. The largest variety ever introduced, weight ranging from 100 to $200 \mathrm{lbs}$. Is very prolific and hardy; flesh is solid, of a beautiful orange color. The seed of this grand new variety is very scarce and it is hard to obtain the true seed. Our stoek comes direct from France and is of the finest. quality. Pkt., 10c; 0z., 15c; 1/4 1b., 40c, postpaid. Beware of cheap seed of this variety. 


\section{Tomatoes.}

Our Tomato seed is grown for us by the most skilleul growers in the World. You will find our descriptions accurate and reliable, and our seed the VERY BEST. Let us prove it to you this year.

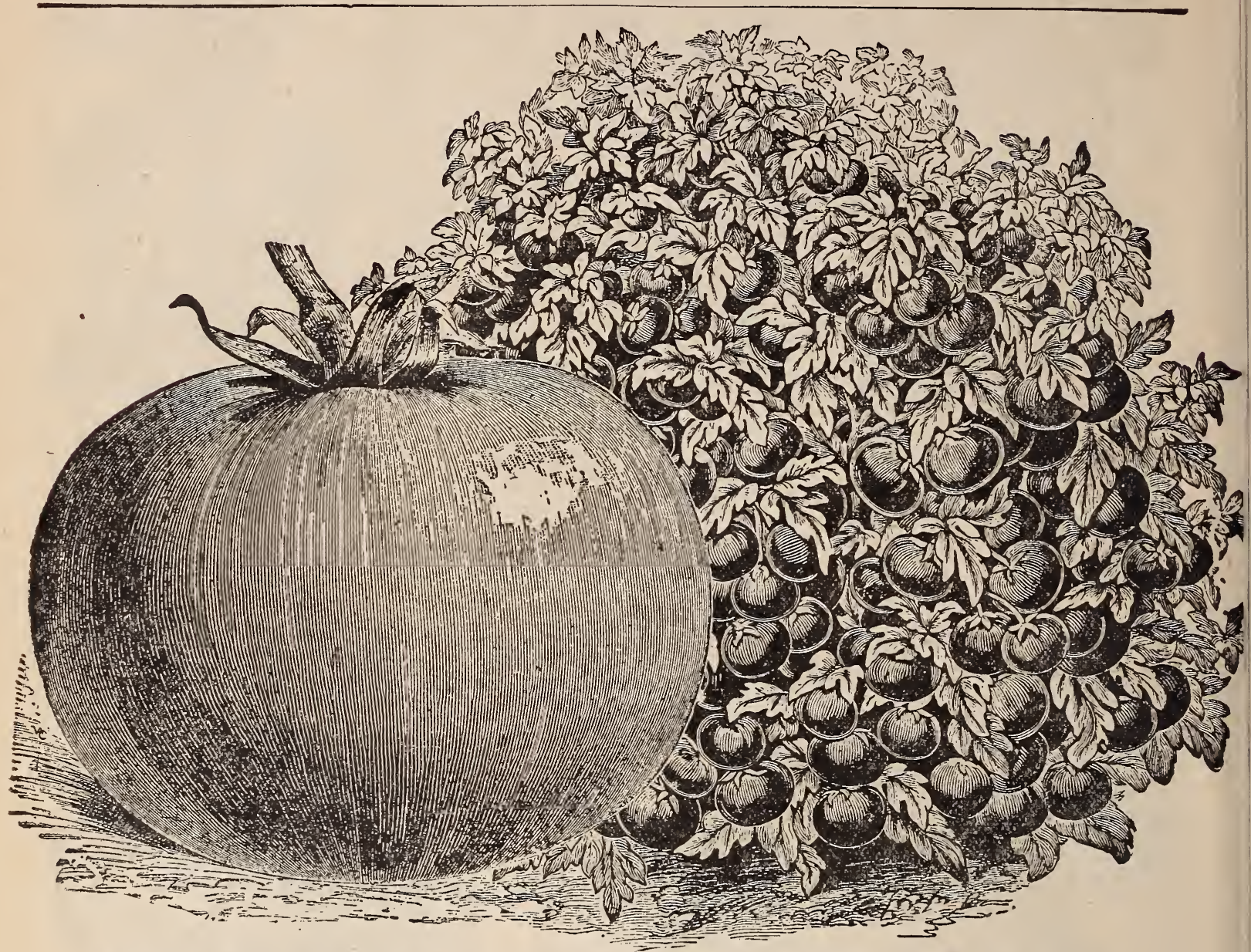

\section{ZIMMERMAN'S EARLY WONDER TOMATO.}

Earliest Tomate in the World.

This variety is truly an Early Wonder and stands without a rival in the early field. Produces its beautiful lucious fruit long before tomatoes are even thought of. This is not to be compared with the socalled earlies offered by many seedsmen, but is a superior tomato and THE BEST OF THE EARLIES. It is of good size, perfectly smooth, round and of a beautiful rich red color. Its earliness, smoothness, superior quality and handsome appearance makes it the grandest Tornato ever introduced. Market gardners can reap a rich harvest by getting the early fancy prices for the first tomatoes. The demand for this variety has been so great the past two seasons that our supply of seed was exhausted before the seasons were one-half over. We hope those who were disappointed in not being able to try this grand tomato last season will order early this year. From all reports, indications are, the demand will be still greater this year, and, while we have a very large stock on hand, we advise early orders. Send in your orders at once. Plkt. 5c.; $1 / 2$ oz. 20c.; oz. 35 c.; $1 / 4$ 1b. $\$ 1.25$, postpaid.

EARLIANA-This variety originated in New Jersey, where competition to be flrst in the market is very great. It is a shy seeder and the seed is always high. It is largely planted by market gardeners, because of its extreme earliness and fine appearance, Pkt 5c., I/2 oz 15c., oz 30c., $1 / 4$ lb 90c., postpost.

EARLY BEA UTY-Another extra early variety of good size, smooth and yields equal to the late varieties. Good quality and scarlet color and produces its fruit, in clusters of tour and five to each cluster, ripening evell 5 . Pkt 5c., 1/2 oz 12c., o\% 2Gc., $1 / 4$ ? 1 b 50c., postpaid.

Beautify your home with Roses and Plants-See our low prices on Pages 54, 55, 56 and 


\section{ZIMMERMAN'S IMPROVED TREE TOMATO.}

In our Improved Tree Tomato we undoubtedly have the very finest of the tree tomatoes and one that is sure to become very popular. It is earlier than the varieties generally offered; has a stout, stocky stem and stands up exceedingly well. It is a very thrifty grower and heavy yielder, producing its bright, glossy red, lucious, fruit in great abundance. The fruit is round, has very few seeds and ripens clear to the stem. Flesh is firm, thick and of most excellent fiavor and seldom rots or cracks, making it a decided improvement over the general run of tree tomatoes. The fruit is produced in clusters and each cluster ripers evenly. It is a fine shipper and especially valuable for market gardeners. While they attain a height of two to three feet, they begin to bear when about six inches high. They do better trained to a stake, as the fruit sometimes weights them down. Pinch off low side shoots until four clusters form. We suppose the sensational seedsmen would have this really grand tomato printed on pink, red or yellow paper in the front part of his catalogue. It would probably be given some high sounding name. He would make a lot of blow and bluster about it and then ask 15c to $25 \mathrm{c}$ a packet. We are not sensational and we want you to try this tomato because it is a good one, and we have made the price Right. Pkt 5c., 1/2 oz 15c,, OZ 25c,, 1/4 lb $90 \mathrm{c} .$, postpaid.

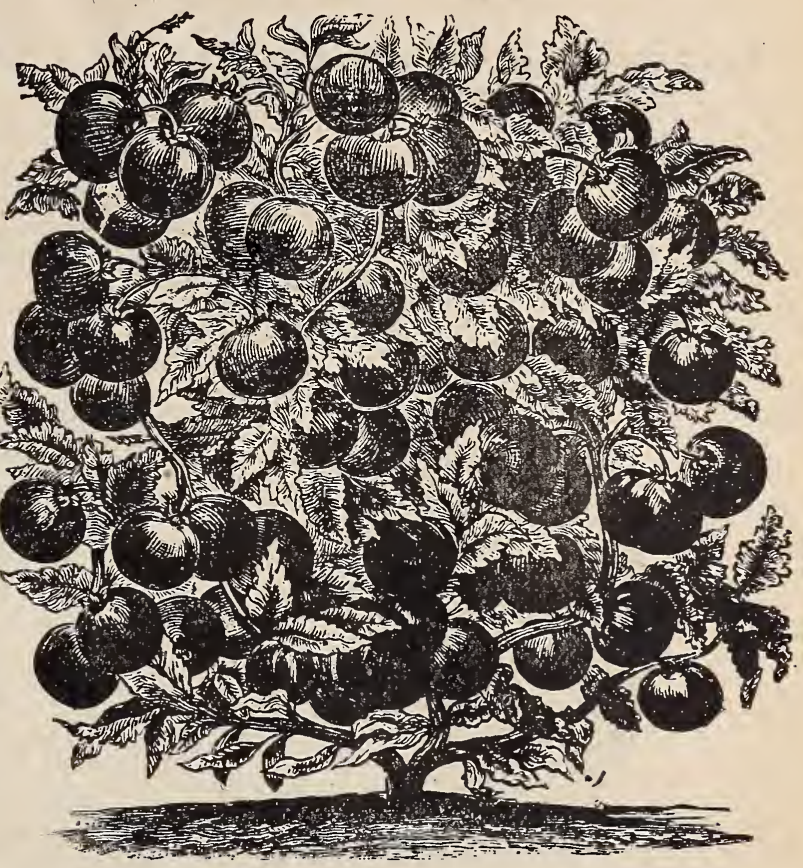

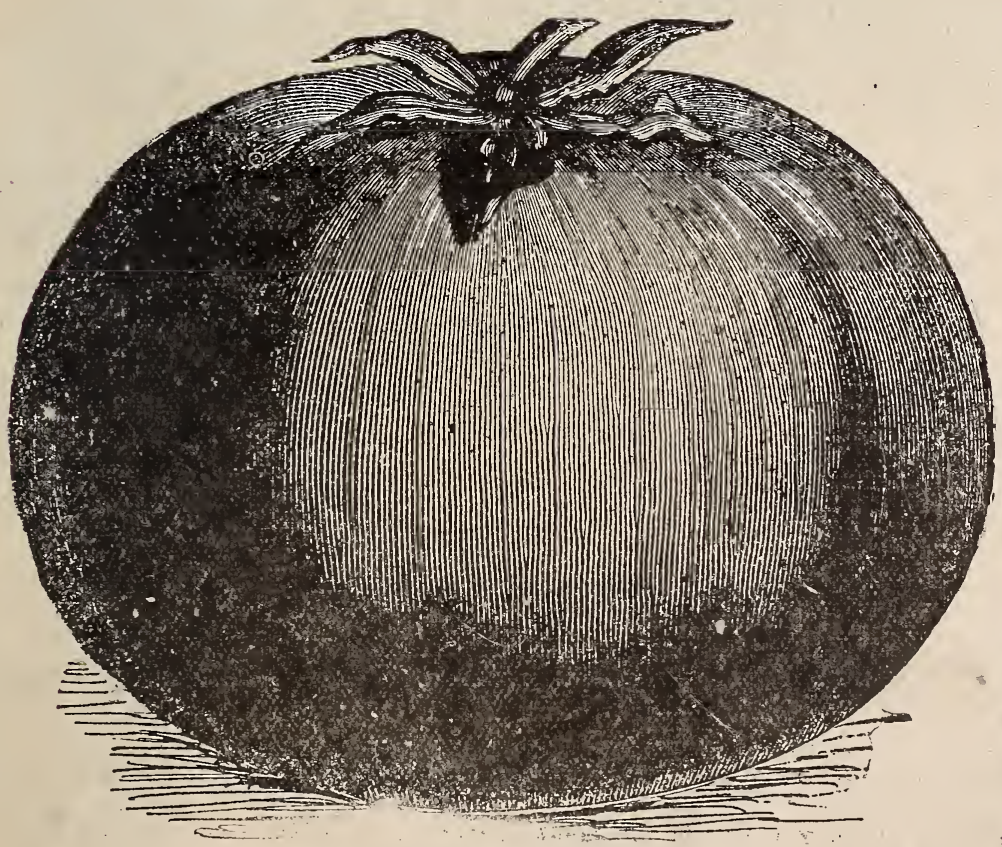

GOI.D DUST TOMATO. (Red)

This is a great novelty and a tomato hard to excel. They are a purplish-red color, medium early, large size, and as SMOOTH AS AN APPLE. The vines are very robust, in fact they closely resemble potato vines, when first started. The vines are very beautiful ; go into your garden mornings and you will find them all sparkling and glistening in the sun like gold, hence the name of GOLD DUST. But their beauty and robust nature is not their strongest point-they are finest of market varieties and their beautiful, round, smooth appearence and large size make them very attractive. They have but lew seeds and the meat is firm and solid. We do not believe they have a superior. A trial will prove our claim that they are the LARGEST, PERFECTIY \$MOOTH TOMATO IN THE WORLD. Pkt 5c.; $1 / 2$ oz $15 \mathrm{c}$; oz $25 \mathrm{c} . ; 1 / 4 \mathrm{lb} 75 \mathrm{c}$; $1 / 2$ lb $\$ 1.35 . ; 1 \mathrm{~b}$ $\$ 2.50$. Dostpaid.

TOMATOES Continuedlon Next Page. 


\section{THE WESTERN GIANT TOMATO. Largest Tomato in the World. Solid, with Few Seeds.}

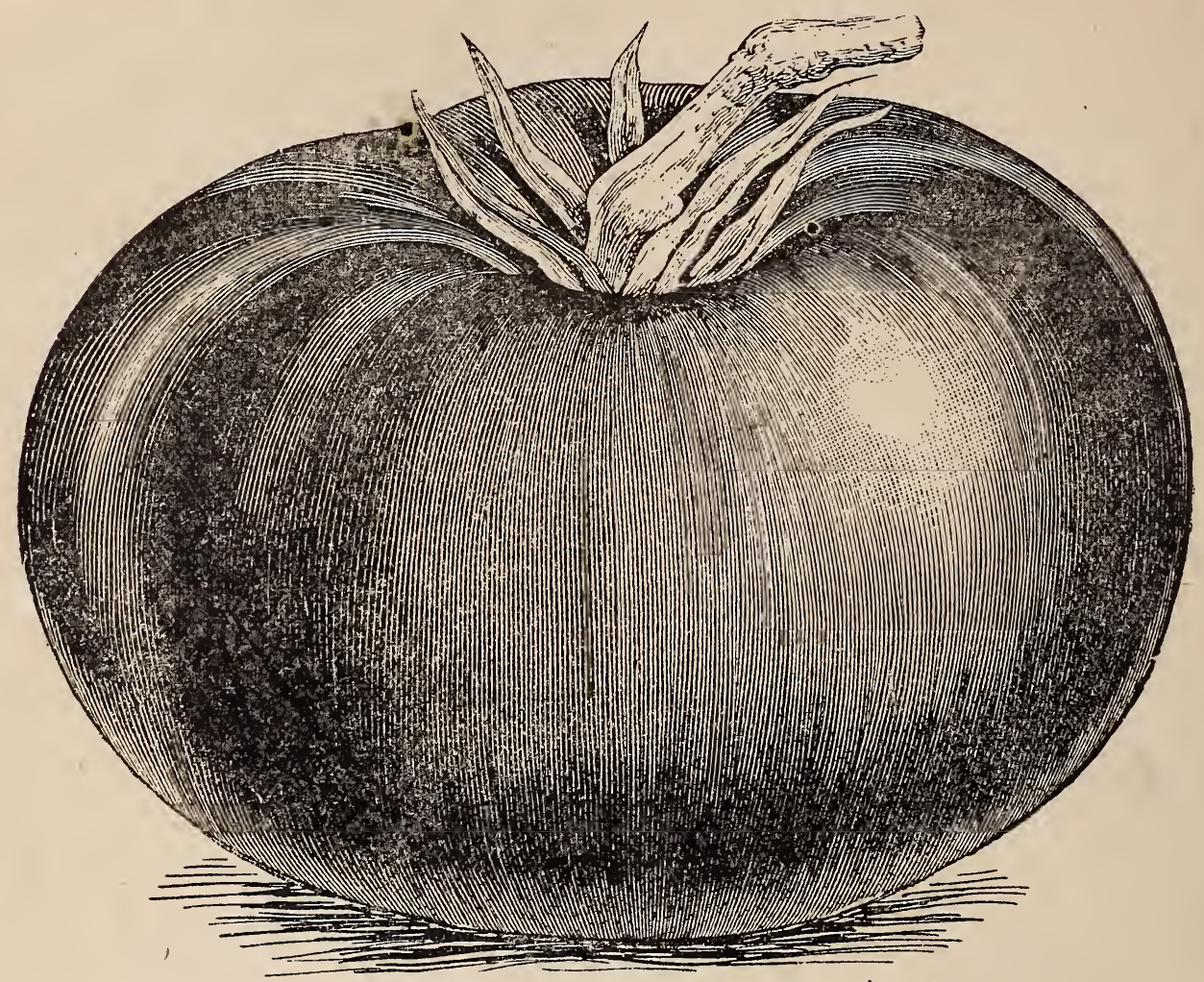

Do you want something that will astonish everyone who sees it? If so, then plant our Western Giant. We have no hesitancy in saying this is absolutely the LARGEST TOMATO IN THE TVORLD. They are simply tremendou and the quality is excellent. It is a handsome red, very solid, few seeds and free from rot; ripens from July until killed by frost. The vines are robust and produce their enormous fruit in great abundance. This is indeed something entirely new in the Tomato world. Try our Giant this year and see what grand Tomatoes you get. Despite the efforts of the "windy" sensational geedsmen to equal this grand tomato, IVE STILL LEAD, and the only way they can reach us is on paper and кот in the garden. We dont rob you by charging 15c or $25 \mathrm{c}$ a packet and then offer you a prize hoping some person might raise a big one (on paper).. WE dont have to buy yields or testimonials. WE dont work "fake" schemes. WE have the goods. Send for this seed; plant it and YOU will raise the largest tomatoos you ever saw in your life. Try it---the price is right. Pkt 5c.; $1 / 2$ oz 15c.; oz 25c.; $1 / 4 \mathrm{lb} 75 \mathrm{c}$, postpaid.

MAGNUS---One of the handsomest large sorts and is unsurpasaed in quality. Form is perfect, uniform and attractive: flesh firm. Ripens evenly to the stem and is a heavy yielder. Pkt 5c.. $1 / 2 \mathrm{oz} 15 \mathrm{c} ., 0 z 25 \mathrm{c} ., 1 / 41 \mathrm{~b} 65 \mathrm{c}$., postpaid,

NEW STONE-Select Improved Strain. The grand main crop vari ety and the King of the Livingston Tomatoes which are the finest and best of the smooth Tomatoes. As its name implies, it is a solid, firm Tomato and an excellent keeper. Ripens evenly to the stem without a crack. A beautiful scarlet color, stem set high and has very small core. Pkt5c; $1 / 2$ oz $12 \mathrm{c}$; oz 20c; 1/4 1b 50, post Dald.

NEW MATCHLESS -Certalnly a matchless Tomato. Skin is unusu ally tough and will keep for many days after being picked. A strong grower and very productive and of large size. Pkt $5 \mathrm{c}$; $1 / 2 \mathrm{oz} 12 \mathrm{c}$; oz $20 \mathrm{c}$; $1 / 41 \mathrm{~b}$ soc, postpald.

PERFECTION - This is an old favorite, equally desirable for home, market and canning; solid flesh, smooth blood red color. It has held its own with all the new varietles and will continue the grand old favorite with many. Plet 5c; is oz 12c; oz 20c; 1/4 1b 50c, postpaid.

FAVORITE-Is a large perfect shaped early Tomato. It is of rich glossy red color. A continuous bearer producing 1 ts beautiful rich fruit from early in the season until frost. Pkt. 5c; $1 / 2$ oz 12c; oz 20c; 1/4lb 50c, postpaid

PARAGON-Large. solid. smooth as an apple and deep red. Pkt 5c; 1/2 oz 12c; oz 20c; 1/4 Ib 50c, postpaid.

GOLDEN QUEEN - A grand yellow variety of superior flavor; unsurpassed as a table variety. A beautiful mooth Tomato, as smooth as any of the red varieties and of distinct rich fiavor. Try it for a yellow Tomato Plt 5c; 1/2 oz 12c; oz 20c; 1/4 lb 50c. postpaid. 


\section{Fine Turnip. $Z_{\text {im }}$}

FARIY WHITE MILAN-The earllest of all. On account of 4 s beautiful shape and earliness, this takes the front place among Turnips. It is so smooth and neat in appearance as to give the impression it was polished by hand. The foliage is scant and short. Both skin and flesh is snowy white. We have select seed of this fine turnip. Pkt $5 \mathrm{c}$; oz $10 \mathrm{c} ; 1 / 41 \mathrm{~b} 25 \mathrm{c} ; 1 / 2 \mathrm{lb}$ 45c: It 80c, postpaid.

PURPLE TOP MILAN-While not as fine a variety as our wHITE MILAN, this is a good eary turnip. Is quite smooth with purple top Pkt5c: oz $10 \mathrm{c} ; 1 / 4$ lb 25c; $1 / 2$ lb $40 \mathrm{c} ; 1 \mathrm{~b} 75 \mathrm{c}$, postpaid.

1. EARLY FIAT DUTCH-An excellent early variety and largeiy used in the South. Roots are of medium size, flat, color white, sweet and tender. A good table variety, but gets inferior when overgrown. Pkt 5c; oz 10c; $1 / 41 \mathrm{lb} 20 \mathrm{c} ; 1 / 2 \mathrm{lb} 30 \mathrm{c} ; 1 \mathrm{~b} 55 \mathrm{c}$, postpaid.

WHITE EGG-A rapid grower: egg shaped: pure white: grows half out of the ground. The flesh is very sweet, mild and frm and is never rank or strang. Pkt 5c; oz 10c; 1/4 1b 20c;1/2 1b 30c; lb 55c, postpaid.

PURPLE TOP STRAP LEAVED-A standard variety; round, flat and of good size. Pk $t$ c; oz $10 \mathrm{c}$; $1 / 41 \mathrm{~b}$

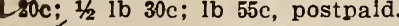

COW HORN-Grows long Pkt 5c, oz 10c, 1/4 1b 20c, lb 50c, postpaid.

SEVEN TOP-Used for greens. Pkt 5c, oz 10c, 1/4 lb 20c, 1b 50c, postpaid.

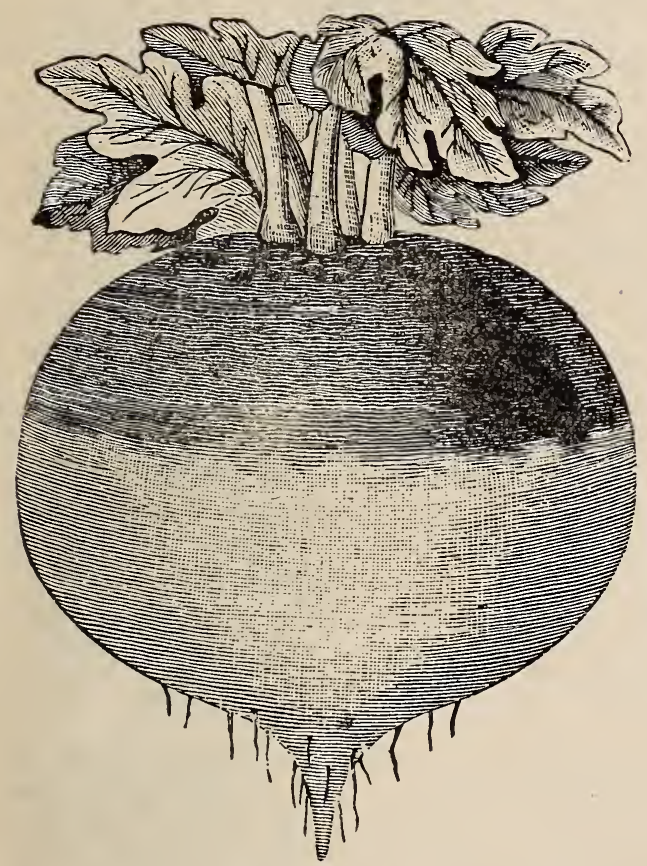

IMPROVED

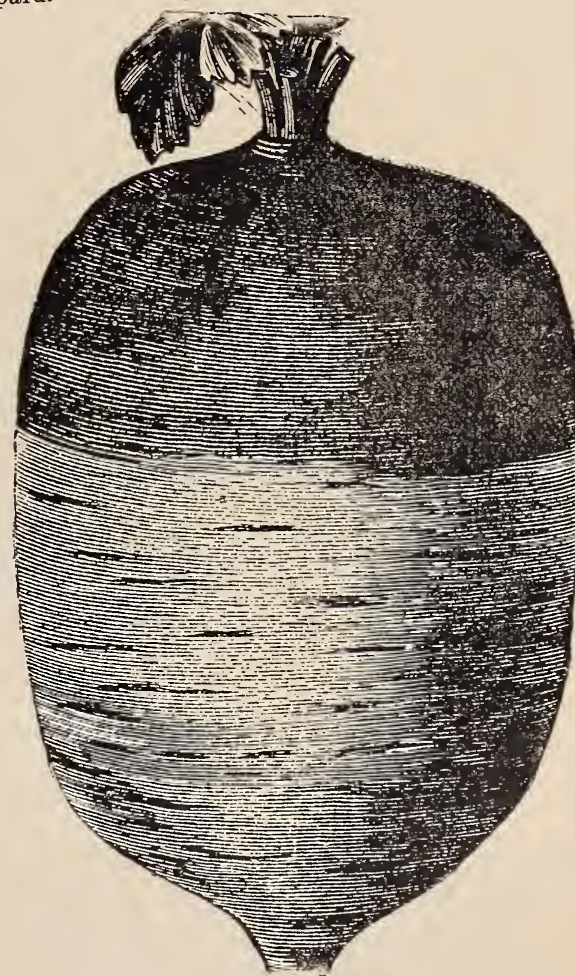

ELEPHANT Or MONARCH.

POMERANIAN WHITE GLOBE-(Strap Leaved). A free growing variety and useful for both table and stock. Not as rapid as the flat varieties but a fine autumn Turnip and good table variety in early winter. Pkt $5 \mathrm{c}$; oz $8 \mathrm{c}$ $1 / 1 \mathrm{lb} 15 \mathrm{c} ; 1 / 2 \mathrm{lb} 25 \mathrm{c}$ : $1 \mathrm{~b} 40 \mathrm{c}$. postpald.

IMPROVED AMERICAN PURPLE TOP-One of the best varities for table and stock feeding: keeps hard and dhitle until summer and is an exceedingly heavy cropper. We consider this one of the best. Pkt 5c; oz 8c; $1 / 41 \mathrm{~b}$ 15c: $1 / 2$ 1b $25 \mathrm{c}$; lb $40 \mathrm{c}$, postpaid.

ELEPHANT OR MONARCH-Produces from three to seven tons per acre more than any other swede, while the hrge amount of saccharine matter contained in them makes them THE VERY BEST FOR STOCK. Pkt 5c; oz $8 \mathrm{c}$ : $1 / 4 \mathrm{lb} 15 \mathrm{c} ; 1 / 2 \mathrm{lb} 25 \mathrm{c} ; 1 \mathrm{~b} 40 \mathrm{c}$, postpaid.

HTR BS. ANISE-Used for seasoning; seeds have an agreeable taste. rkt. 5 cts.

. BORAGE-Leaves are used for flavoring, flowers good food for bees. Pkt.5 cts.

CARAWAY-Grown for the seeds, which are used for flavoring bread and pastry. Pkt. $5 \mathrm{cts}$. CATNIP-Used for bee pasture, flavoring and teas. Pkt. $5 \mathrm{cts}$.

CORIANDER-Seeds are used in manufacture of confectionery and beverages. Pkt. 5 cts.

DILL-The seeds have an aromatic odor and are used largely for pickling with cucumbers. Pkt. 5 cts.

HOREHOUND-Used for medicinal qualities, mostly for cough remedies. Pkt. 5 cts.

HOP SEED-Pkt. 15 cts.; 2 for 25 cts.

LAVENDER-Used for sweet odor in making of perfume. Pkt. 5 cts.

SAFFRON-Used for coloring and flavoring of perfume. Pkt. 5 cts.

SAGE-More used than any other herb for seasoning. Pkt 5 cts.

SAGE-More used than any other herb for seasoning. Pkt 5 cts. 5 cts.
SUMMER SAVORY-Used for flavoring soups and dressings. Pkt. 5 cts.
WINTER SAVORY-Used for flavoring soups. Pkt. 5 cts.

THYME-Used for seasoning and medicinal quallties. Pkt. 5 cts 


\section{An Open Letter About}

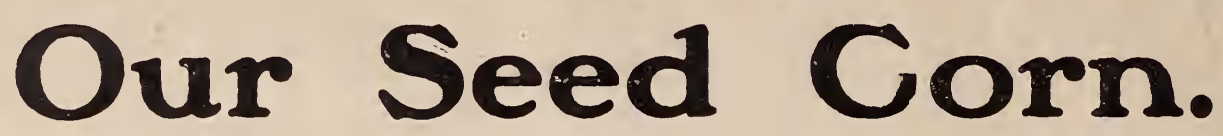

The Seed Corn we offer was not only grown and acclimated to the Southwest, but was actually grown under our supervision, gathered into our warerooms, and carefully hand-sorted, EVERY EAR carefully inspected, making it the most perfect grade of Seed Corn possible to produce. Good seed is of as much importance as good soil and cultivation.

Carefully sorted; all nubbins, inferior ears, etc thrown out; tipped, butted, shelled and graded to a perfect uniform size and shape, it will pass through your planter without clogging. Hardly an imperfect grain. Does that appeal to you Mr. Farmer? Every grain that goes into your field perfect. 국 Dont you think it will pay you to plant this kind of seed? Dont you think it will produce 10 to 25 bushels more to the acre? Dont you think IT IS WORTH MORE than that generally offered? And its just as we say it is, and if you dont find it so, send it right back and get your money.

Yours for abundant crops,

J. S. ZIMMERMAN.

\section{WHICH HIND DO YOU PLANT?}

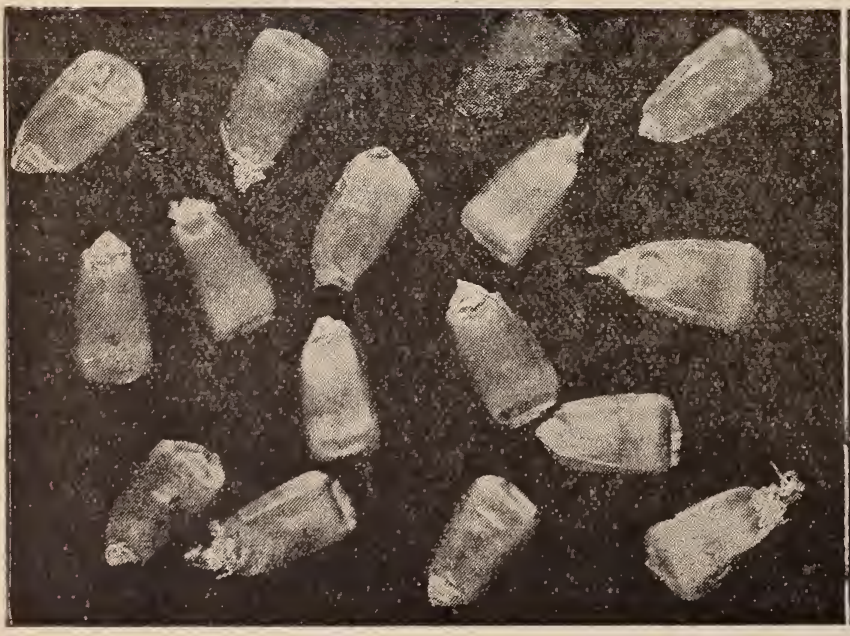

This is the way Our seed Corn runs. All perfect size, and shape.

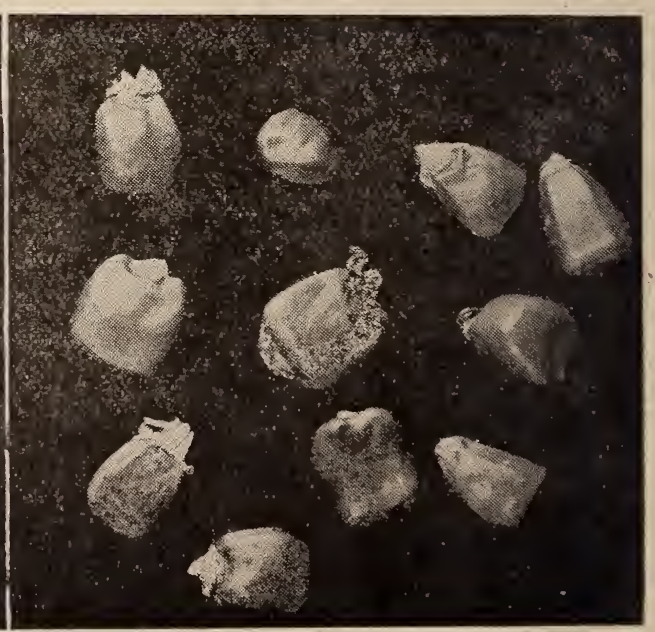

The kind you sometimes get from others. All sizes, shapes and forms. 


\section{COMBINATION.}

The Largest Grained, Heaviest Yielding Corn Ever Introduced. Out-yielded All Other Varieties

in the Equal Trial at

Kansas Agricultural College, Manhattan, Kans.

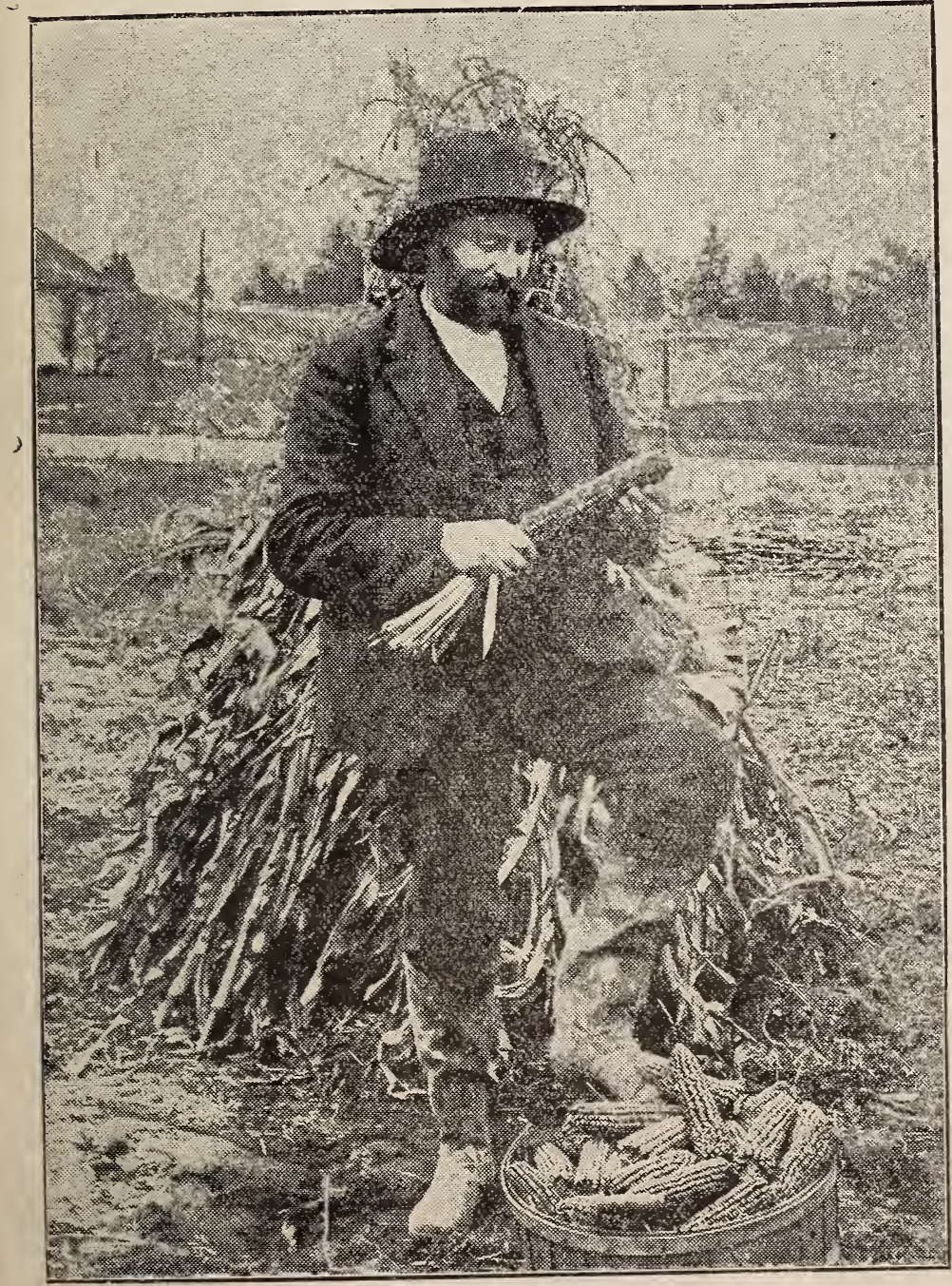

"COMBINATION" FROM A PHOTOGRAPH.

Yes, its the best grown. The Very Best. Combines more good qualities than any other corn we ever heard about. We first introduced this corn to our customers four years ago and we have been making strong claims for it ever since, and it has always surpassed OUR claims. Now comes the State Agricultural College of Kansas with a statement that in the equal growing test, wlth 80 OTHER VARIETIES, our COM B I N A T I O N OUTYIELDED THEM ALL, making a yield of $58.75 \mathrm{bu}$, while McAuley's White made 57.3; Golden Row 53.75; Hildreth 51.75; Kansas Sunflower 49.1 ; Boone County White 46.3; Silver Mine 45.9; Reid's Yellow Dent 45.1, etc.

Foot by foot, rod by rod, acre by acre, vear after year it will be your winning corn. We want YOU to plant it. The main color is ox-blood, surmounted with yellow in such a manner as to give it the appearance of a yellow corn on a red background, blending into a beautiful and attractive combination. No picture, no illustration can do it justice, The stalks are large and strong. and withstand heavy storms, while the large, deep grains are very nutritious, making it a most valuable corn for feeding purposes. Now listen! Every grain of this corn was grown according to our directions; carefully sorted, HAND TIPPED and BUTTED and shelled by experienced men and we KNOW it is pure ; we KNOW just what it is and what it will do. If you dont find it just as we describe it, SEND IT RIGHT BACK and get your money. That is the way WE do business. We offer it 3 ways, but recommend that you order the graded. Carefully shelled and graded to uniform size, the highest grade of perfection; pkt 5c., pt 15c.. qt 25c.. postpaid. By express or freight, Ipeck 50c., $1 / 2$ bu 80c., bu $\$ 1.50$ 2 bus $\$ 2.80,5$ bus $\$ 6.50,10$ bu $\$ 12.00$. 2nd: Carefully selected, but not graded, peck $40 c^{\cdot}, 1 / 2$ bu $70 c$., bu $\$ 1.25,2$ bus $\$ 2.25$. 5 bus $\$ 5,00$, 10 bus $\$ 9.00$. In the ear, crated, $\$ 1.60$ per bu, 2 or more bu at $\$ 1.50$ per bu. 


\title{
WHITE MONEY-MAKER.
}

\author{
A PURE SNOW WHITE.
}

A GRAND VARIETY.

The Best Milling Corn in the World.

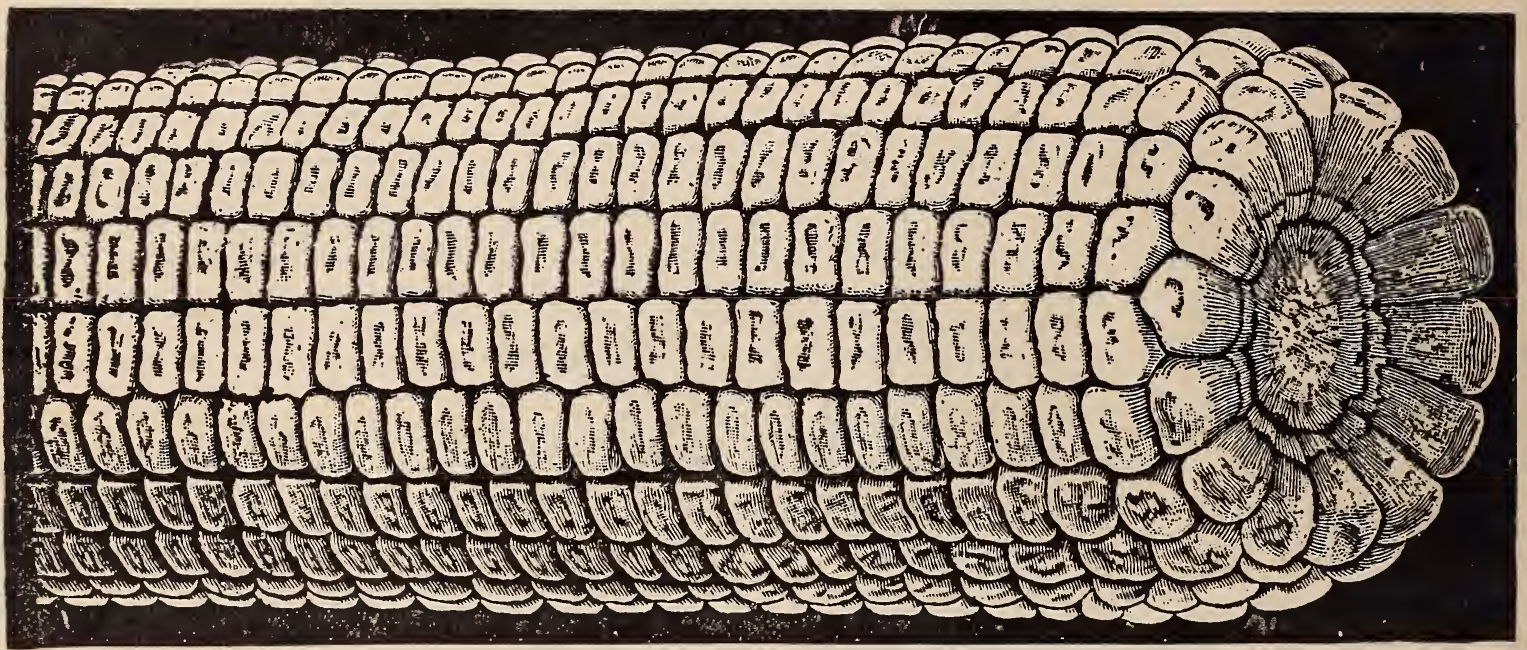

We have here a corn which easily stands at the head of all white varieties. Is earlier than White Pearl and has out-yielded Silver Mine side by side. 75 pounds of ears shelled 70 lbs of corn. Matures in 90 days, the ears running 10 to 12 inches in length; cobs are small and contain from 16 to 20 rows of deep, pure white zernels. No! we dont claim it will yield 300 bushels per acre, but we DO claim it will out-yield varieties claimed to give such fabulons yields. We claim it to be the HANDSOMEST, HARDIEST, WHITEST DENSEST most UNIFORMED kerneled, SUREST MATURING and BEST white corn we have ever seen. We want you to see this varietv. We want you to plant this variety It will out-yield anything you ever saw in a corn field. And the color! it is the prettiest pure snowy white von ever sam.

The seed we offer was cultivated with the greatest possible care. It was Hand Sorted, Tipped, Butted and Shelled in our warerooms. All leading authnrities on seed corn declare that Pure Seed Corn raised in and acclimated to the Southwest, will give more general satisfaction than seed corn grown in another section and climate. We exercise the greatest possible care in the cultivation and selection of our seed corn and that is the reason We Have only The Best. Selected, tipped, butted, shelled and graded to uniform size. Pkt 5c.; $1 / 2$ pt 10c.; pt 15c.; qt 25c., postpaid. By express or freight, pk 40c.; $1 / 2$ bu $75 c . ;$ bu $\$ 1.40 ; 2$ bu $\$ 2.65 ; 4$ to $10 \mathrm{bu}$ at $\$ 1.25$ per bu. $\quad 2$ nd: Selected but not graded, pk $35 \mathrm{c} . ; 1 / 2$ bu $65 \mathrm{c}$.; bu $\$ 1.10 ; 2$ bu $\$ 2.004$ to 10 bu at 90 c. per bu.

In the ear crated $\$ 1.60$ per bu.

\section{SILVER MINE.}

A 90-day white variety and one of the heaviest ylelders ever planted.The stalks grow 7 to 8 feet in height; the ears run from 10 to 12 inches long: cob is small and contain from 16 to 20 rows of pure wh:te kernels of large size and very deep. Pkt. 5c; $1 / 2$ pt 10c; pt 15c; qt 25c, postpaid. By express or freight; Graded to uniform size, qt 10c; pk $40 \mathrm{c}, 1 / 2$ bu $75 \mathrm{c}$., bu $\$ 1.40,2$ bu at $\$ 1.30$ per bu. 5 to 10 bu at $\$ 1.25$ per bu. 2nd, Selected but not graded to uniform size. pk $35 \mathrm{c}$. $1 / 2$ bn $65 \mathrm{c} ., \mathrm{bu} \$ 1.102 \mathrm{bu}$ at $\$ 1.00$ per bu. 5 to $10 \mathrm{bu}$ at $90 \mathrm{c}$. per bu. In the ear at $\$ 1.60$ per bu

\section{BOONE COUNTY WHITE.}

Matures in 110 days. Ears average from 8 to 12 inches in length and contain 16 rows of pure white, deep, compact and very heavy kernels. The kernals are larger than any other white corn. It is a BIG corn. Meal from this corn makes A No. 1 on the market. Pkt 5c; 1/2 pt 1nc; pt 15c; qt 25c, postpaid. By express or fre ight Graded with our Grading machines. Every kernal of uniform perfect size and shape, peck 50c., $1 / 2$ bu $80 \mathrm{c}$. . bu $\$ 1.50,2$ bu at $\$ 1.30$ per bu, $5 \mathrm{bu}$ at $\$ 1,20$ per bu. $10 \mathrm{bu}$ at $\$ 1.10$ per bu. 2nd Selected, but not graded to uniform size, All pure, so und seed and superior to seed corn generally sold, peck $403 ., 1 / 2$ bu $65 \mathrm{c}$., bu $\$ 1.10,2$ bu at $\$ 1.00$ per bu. 5 bu at $90 \mathrm{c}$. per bu, 10 bu at 80 c. per bu. In the ear crated, extra choice ears at $\$ 2.00$ per bu. 


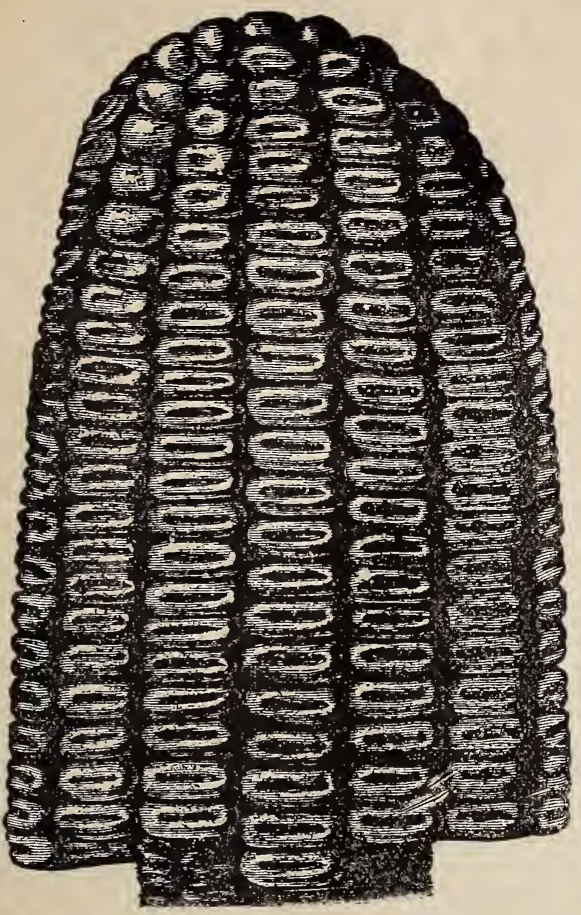

PERFECTED GOLDEN BEAUTY.

\section{Early Golden Eclipse.}

\section{An Extra Early Yellow Corn.}

The finest and heaviest yielding early yellow corn. Most beautiful formed ears and finest rich golden color. Whatever can be said of any other early vellow corn can be said of this one, AND MORE. It is early, a heavy cropper, deep kerneled and very hardy. Cobs small and filled to the tip with bright golden grains. Its rich color makes it fine for grinding into meal as well as feeding purposes. An early corn that cannot be eclipsed. Selected, tipped, butted and graded, pkt 5c.,pt $15 \mathrm{c} .$, qt $25 \mathrm{c}$, postpaid. By express or freight, pk 40c., $1 / 2$ bu $75 \mathrm{c}$, bu $\$ 1.40,2$ bu $\$ 2.60,4$ to 10 bu at $\$ 1.25$ each. 2nd, selected, but not graded, pk 35c., $1 / 2$ bu 60 c., bu $\$ 1.10,2$ bu $\$ 2.00,4$ to 10 bu at $90 \mathrm{c}$ each. In the ear, crated, $\$ 1.60$ per bu.

\section{PERFECTED}

\section{GOLDEN BEAUTY.}

The Perfected Golden Beauty cannot be surpassed by any yellow corn. The largest and heaviest grains of any yellow corn. If you want to grow big corn; ears that run from 10 to 15 inches in length and filled to the very tip with big, solid grains, our big Perfected Golden Beauty is just what you want. Ears are of perfect form and contain 12 to 16 rows of bright yellow grains, of extra large size, to the very tip. It is a fine feeder, while its rich color makes it fine for meal. Sorted, tipped, butted, shelled and graded to uniform size, pkt 5c., pt 15c., qt 25c., postpaid. By express or freight, pk $40 \mathrm{c}$., $1 / 2$ bu $75 \mathrm{c}$., bu $\$ 1.40,2$ bu $\$ 2.60 .4$ to 10 bu at $\$ 1.25$ per bu. 2nd, Selected, but not graded, pk 35c., $1 / 2$ bu $60 \mathrm{c}$., bu $\$ 1.10,2$ bu $\$ 2.00,4$ to 10 bu at $90 \mathrm{c}$ per bu. In the ear crated, $\$ 1.60$ per bu.

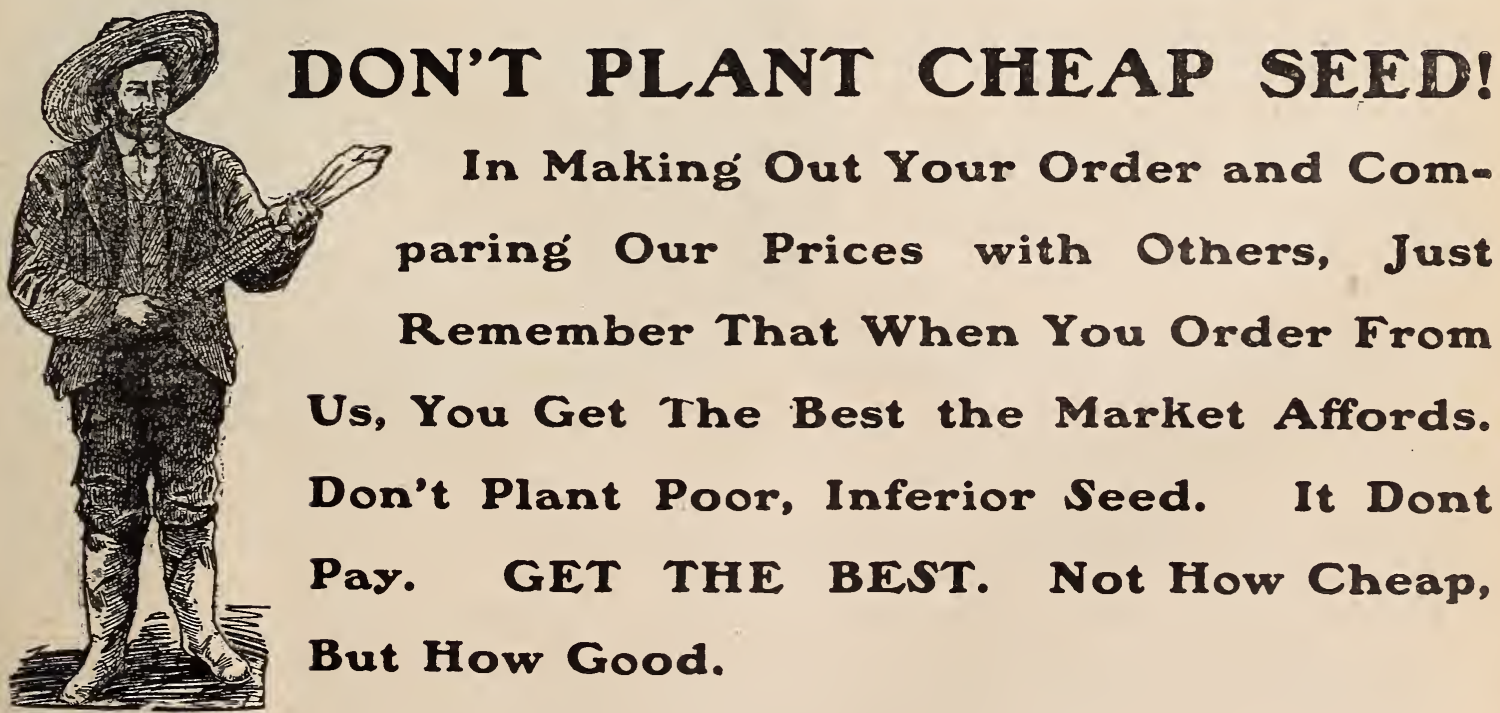




\section{Northern Potatoes.}

Our stock of Seed Potatoes cannot be excelled. They are pure Northern stock of the finest and hardiest quality and have given our customers perfect satisfastion year after year. Prices are subject to market changes. Write for special and latest prices on large quantities. In buying from us, remember you are dealing with a house that has a well-earned reputation for fair, square dealings. WWE'LL TREAT YOU RIGHT.

\section{EAREX DELIGHT POTATO.}

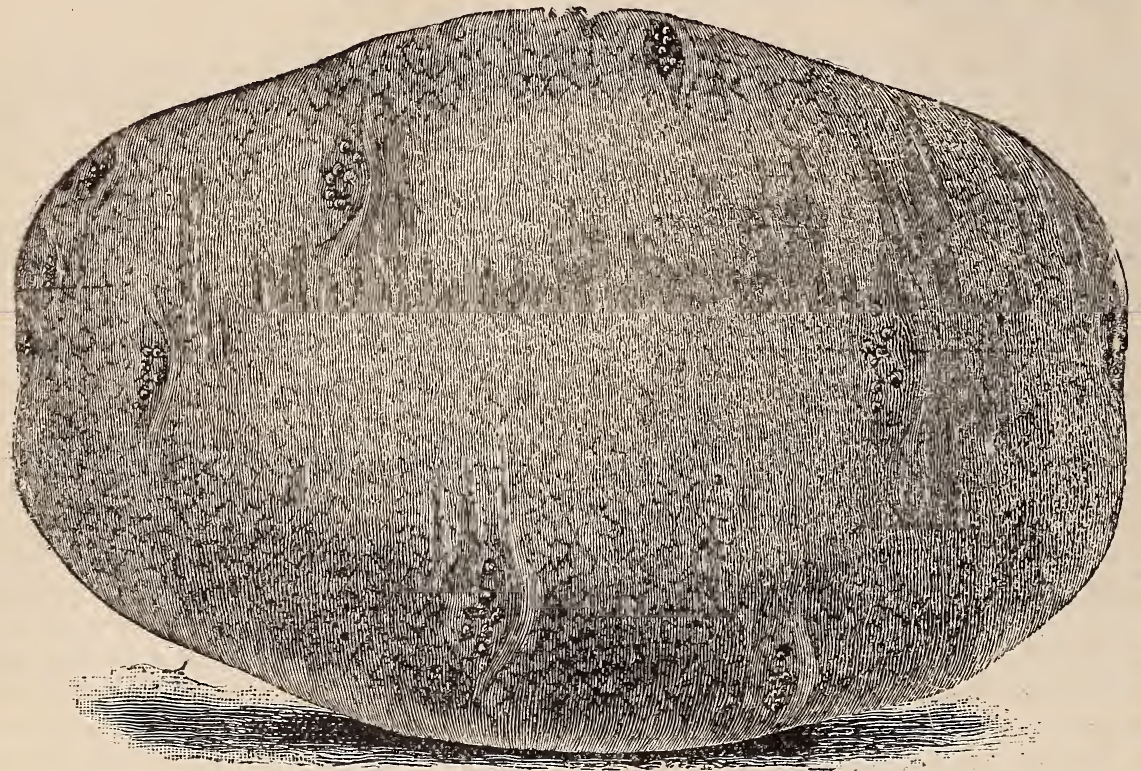

Another year adds to the popularity of our Early Delight potato. It is $n$ ot only very early, but out-yields most of the later sorts. It has been planted in almost every state and our customers report heavy yields and perfect satisfaction. A cross between the Early Ohlo and Six Weeke; combining the heavy yielding qualities of the Ohio with earliness of the Six Weeks, thereby making it an ideal potato. It is of handsome form and light color; comes true and not easy to "scab." A firm potato and fine keeper, while its cooking qualities cannot be excelled. Try this one-the price is right. I, b 15c.; 3 lbs 35e, postpaidBy express or freight, $\mathrm{pk} 40 \mathrm{c}$, $1 / 2$ bu $75 \mathrm{c}$., bu $\$ 1.40$, barrel of $23 / 4$ bu $\$ 3.25$.

EARLY DELIGHT POTATO.

\section{THE EARLY OHIO.}

The Early Ohio is the leading potato in the West and is more generally planted than any other variety. It seems to be especially adapted for this section. With the exception of our Early Delight, the Red River Early Ohios have given more general satisfaction to our customers than any other potato. They are ready for market very early, are heavy yielders, good keepers and one of the finest table va. rietles. We Guarantee Our Stock to be genuine Northern Red kiver. Dont buy "cheap" seed pota" toes from doubtful places. We have pure stock, firm and sound. By express or freight, peck 35c., $1 / 2$ bu 65 .. bu $\$ 1.20$. bbl of $23 / 4$ bu $\$ 3.20$.

\section{Early Triumph.}

Combines productiveness, earliness and heavy yielding qualities. A grand potato and great favorite. The color is a beautiful light red and they grow to a large size. Hardy Red River Stock : by express or freight, peck $40 \mathrm{c}, 1 / 2 \mathrm{bu} 70 \mathrm{c}$, bu $\$ 1.25$, bbl $\$ 3.30$.

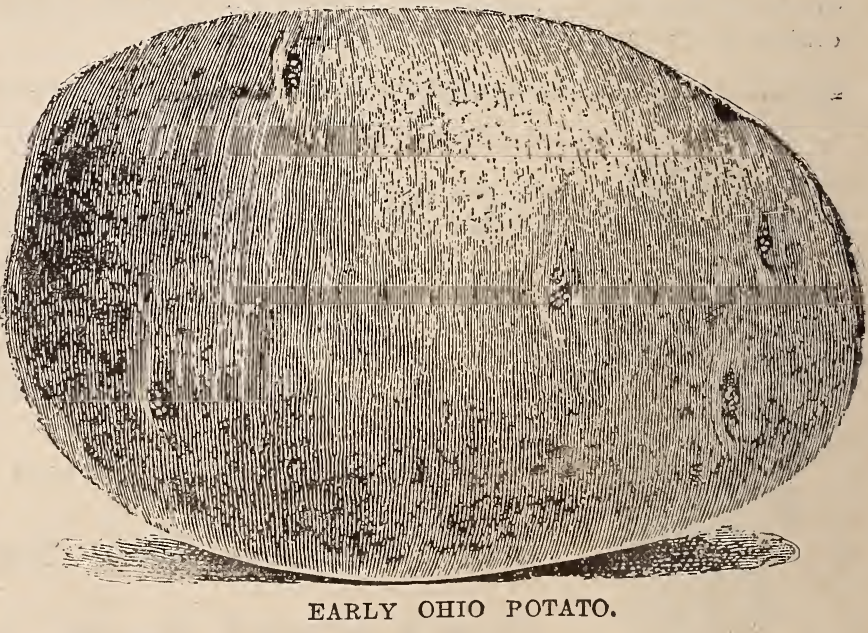

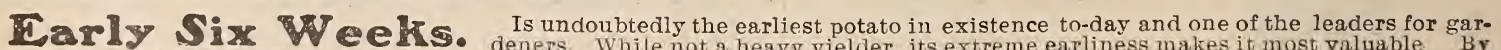
express or freight, peck $35 \mathrm{c}, 1 / 2$ bu $60 \mathrm{c}$., bu $\$ 1.00$, bbl of $23 / 4$ bu $\$ 2.70$.

The Barband. A late large, heavy yielding potato and is the favori te main drop potato in the West. Of fine

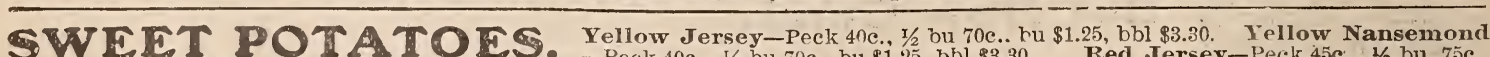
bu $\$ 1.40, \mathrm{bbl} \$ 3.50$. Red Nansemond and Bermuda Red same price as Red Jersey.

SWEET POTATo PLANTS. 50 for 30c., 100 for 50c, by mail postpaid. By express 100 for 30 c., 500 for $\$ 1.15,1,000$ for $\$ 2.00$. 


\section{DWARF ESSEX RAPE. \\ Most Popular and Productive of Forage Plants.}

Grows on all kinds of soil; requires no cultivation after sowing. While the greatest claims for Rape are made as a forage for sheep and hogs, it is equally as good as a pasture for all kinds of stock. A good crop will yield 15 to 20 tons of green fodder per acre and will pasture 30 head of sheep for over two months, getting them in fine shape for market. All animals seem to prefer it to any other pasture during the entire summer and until late fall. Can be sown early to provide early pasture for sheep and hogs, but is usually sown in May or June for summer and fall pasture. When sown broadcast, use $7 \mathrm{lbs}$ per acre. If in drills, $4 \mathrm{lbs}$ per acre. Price of select well cleaned seed: per lb 20c.; 3 lbs 50c., postpaid. By express or freight, 5 lbs

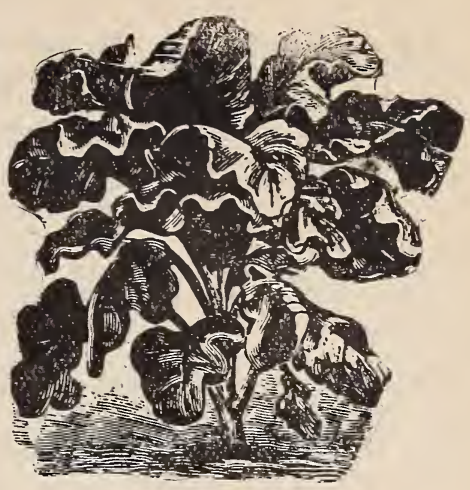
$50 \mathrm{c}, ; 10$ to $20 \mathrm{lbs}$ at $7 \mathrm{c}$ per $1 \mathrm{~b} ; 25 \mathrm{lbs}$ and over at $5 \mathrm{r} / 2 \mathrm{c}$ per $1 \mathrm{~b}$.

IA IRR COR. T. WHrTE-The most popular variety. Grows 4 to 5 feet high, with large leaves and does not per acre. Lb 20c., postpaid. By express or freight, 10 to $251 \mathrm{bs}$ at $1 \frac{1}{2} \mathrm{c}$ per $1 \mathrm{~b}$., $50 \mathrm{lbs} 70 \mathrm{c}$., $100 \mathrm{lbs} \$ 1.30,200 \mathrm{lbs}$ and over at $\$ 1.25$ per 100 RED--.Lb 20c.. postpaid. By express or freight, 10 to $25 \mathrm{lbs}$ at $2 \mathrm{c}$ per lb, $50 \mathrm{lbs} 90 \mathrm{c} ., 1001 \mathrm{bs} \$ 1.60$.

JERUSAR CORN. Is pronounced even better than Kafir Corn for dry countries and seasons. It ral small heads on side shoots. The grains are pure white and nearly flat. 3 lbs will plant one acre. Lb 20c postpaid. By express or freight, 10 to 25 lbs at 4 ; per lb. ; 50 lbs $\$ 1.90,100$ lbs $\$ 3.75$.

BROOM CORN. oKLAHoma DWARF-Is early, of dwarf habit, resists drouth and is very productive. mediately after brush is palle d. the stalks make excellent fodder. Drill 3 ib of seed per acre. Lb I5c postpaid. By express or freight, 5 to 30 lbs at $4 \mathrm{c}$ per $1 b, 50$ ibs $\$ 1.50$.

EARLY JAPAN-Matures in 70 to 80 days. Can be planted after wheat with good results. Lb 15c postpaid, By express or fre:ght, 10 lbs $50 \mathrm{c}$. 20 to 50 lbs at $4 \mathrm{c}$ per pound. EVERGREEN-Fiber long and straight. Same price as the Japan.

CA T T STED.AMBER-The earliest and a favorite; makes fine syrup and good sugar. Makes excellent hay $100 \mathrm{lbs} \$ 1.70$. prices before ordering any quantity. ORANGE CANE-Larger, heavier and later than Amber, Same price as Amber.

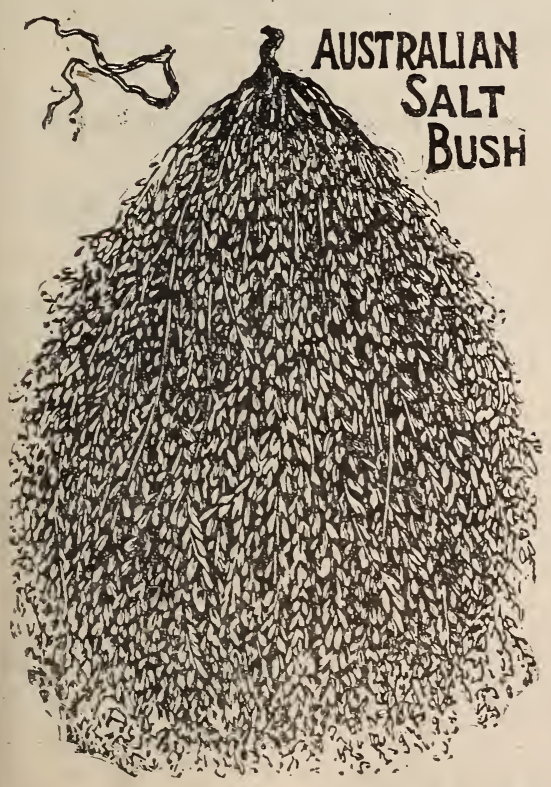

\section{Australian Salt Bush.}

A wonderful foliage plant; grows freely in arid and alkali lands that wil produce no other vegetation, It is of heavy grow th and readily eaten by stock It is claimed that four crops grown on the poorest soil will so enrich it that an vegetation may be grown. Sow seed in beds and transplant when two inches high, 7 feet apart. One pound will plant an acre. Pkt 10c., oz $20 \mathrm{c}$., $1 / 4$ to $40 \mathrm{c} ;$ in \$1.35 postpaid.

MAMMOTI SUNELOWER. Grows to an and the seed makes fine food for fowls. $\mathrm{O} z 5 \mathrm{c}$., $1 / 2$ ib $12 \mathrm{c}$., $1 \mathrm{~b} 20 \mathrm{c}$, postpaid

SOIA Or SOM BEANS. Early Yellotv to 6 stems branch out from the ground, reaching a height of 2 to 4 leet Cows hogs, etc. thrive npon them If drilled, use $1 / 4$ to $1 / 2 \mathrm{bu}$ per acre; if scattered, 1 bu. Pkt 5c., lb 20c, postpaid By express or freight, Ib 10c; pl $90 \mathrm{c} ; 1 / 2 \mathrm{bu}$ $\$ 1.40 ;$ bu $\$ 2.60$

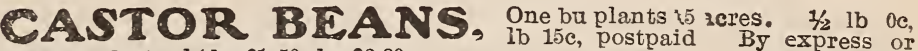
freight, pk $80 \mathrm{c} ; 1 / 2$ bu $\$ 1.50 ;$ bu $\$ 2.80$

COVI P. A fine fodder and rertilizer Either the Black postpaid By express or freight, pk 75c, $1 / 2$ bu $\$ 1.30$, bu $\$ 2.50$

TOBACCO. Either Connecticut Seed Leaf or Big Havana;

Our Fida Seeds are Fresh and Well Cleaned: OnIy THE BEST Quality. 
Alfalfa is particularly adapted to our Western soil and climate; is also winning popularity in othe sections and praise comes wherever it is planted. In dry, hot, sultry weather, when other forage and grass is parched and withered, Alfalfa is fresh and green, the roots going down 15 to 20 feet The soil is rather improved by 18 . although a heavy yielder. Sow not later than Sept, in Kansas and like climates. The best time, however, is to sow as early $\Omega$ the spring as the weather will permit, using not less than $25 \mathrm{lbs}$ per acre, for feeding, or $12 \mathrm{lbs}$ if for seed. There are many grades of Alfalfa seed: Some are cheap and worthless. We are located in the Alfalfa section and are in a position to offer the best the market affords and at a low price, We offer the following grades:

PURE GOLD-We believe this to be as fine quality of Alfalfa as is possible to secure. Selected with the greatest care, and cleaned and graded with the finest machinery, the grains are indeed golden. Pkt 5c., lb $25 \mathrm{c}$ postpaid, By express or freight, 10 lbs $\$ 1.50,30 \mathrm{lbs} \$ 4.40$, bu ( $60 \mathrm{lbs}) \$ 8.50$.

CHOrCE---Strong, fine plump seed and equal to the highest grade generally sold. By express or freight, $10 \mathrm{lbs} \$ 1.40,30 \mathrm{lbs}$ $\$ 4.10, \mathrm{bu} \$ 8.00$.

PRIME-Generally sold for second grade. By express or freight, $10 \mathrm{lbs} \$ 1.25,30 \mathrm{lbs} \$ 3.70$, bu $\$ 7.25$.

WRITE FOR LATEST PRICES ON LARGER QUANTITIES.

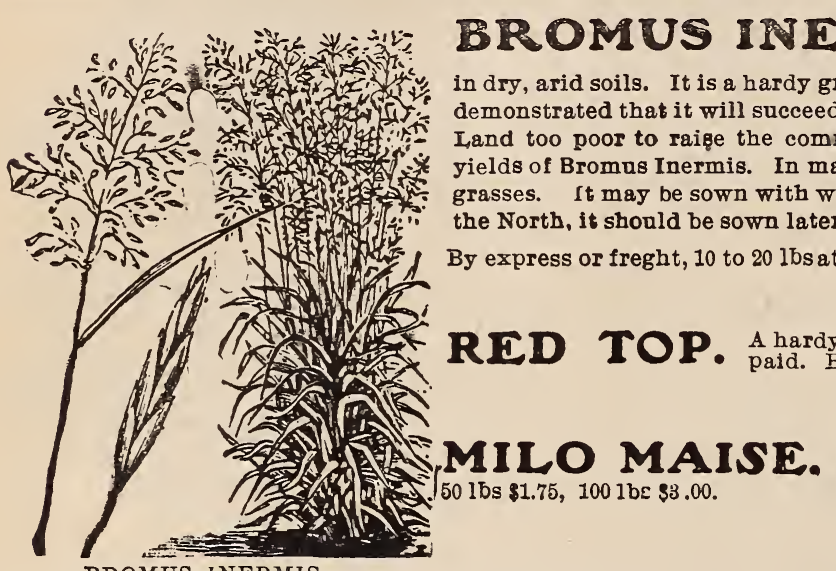

(Awnless Brome Grass.) It grows
from 3 to 5 feet and does especially we: suceed in a wider range of temperature than any other grass. common agricultural grasses and crops, will give splendid yields of Bromus Inermis. In making permanent pasture, it should be sown with other grasses. It may be sown with winter wheat in the Southern states in Febor March. In Sown later. Sow 20 to 30 lbs per acre. Lb 30c., 3 lbs 70c, postpaid. BROMUS INERMIS

ENGLISI BLUE GRASS. (Meadow Fescue)-Oue uf the most productive and nutritious o: Pkt 5c., 1b 15c postpaid. By express or freight. $1 / 2$ bu $\$ 1.00$. bu (22 lbs) $\$ 1.80$. Tou will notice wo figure 22 lbs to the busbel, while some only ffgure $14 \mathrm{lbs}$. Write for latest prices on larger quantities.

TIMOTHY. Unsurpassed as a hay crop. Sow $10 \mathrm{lbs}$ per a are. By express or freight, $10 \mathrm{lbs} 60 \mathrm{c}$. bu (45 lbs) \$2.25.

ORCHARD GRASS. Does well in the shade Sowtwenty lbs per acre By express or fraight at

GLRMAN MILIEL. One of the heaviest yielding forage plants. Produces 4 to 5 tons of has per acre. (s closely allied with Hungarian Millet, but a heavier yielder and much superior 20c., pk 30c. bu 90c.

\section{JAPANESE MILLET or "Billion Dollar Grass."}

This variety has been sold at high prices under the title of "Billion Dollar Grass. It has a claim of over twenty tons of green forage per acre. The forage is tender and relished by stock, superior to corn fodder, for cows. Sow about 12 ats per acrc about May, but can be sown as late as Aug, with good results. Pbt 5c., lb 30c., postpaid. By express or freight, at $4 c$, per lb.

SIBERIAN MILIET. This variety from Russia has given great satisfaction in the United states. II ing 5 large crop. Sow in May or June at the rate or 1 peck per acre. Plat 5 c., 1b 20c., 3 lbs 50c, postpaid. By express or freigh: nk 3ne. bu gor.

\section{SPELTZ or EMMER.}

Speltz is endorsed by all who have tried it. It will grow anywhere and makes a good pasture when in the green stage; when matured. is threshed out like wheat, only not so close: hull and kernal can then be fed or ground. Cows, horses, sheep and especially hogs, thrive upon it. Prepare ground and sow like oats, using about 40 lbs per acre.. PLANT THE BEST: Our Speltz seed is selected with great care and is well cleaned. Lb 15c.. postpaid. By express or freight, pk $25 \mathrm{c} ., 1 / 2$ bu $40 \mathrm{c} .$, bu $75 \mathrm{c} .$, 8 to 5 bu at $70 \mathrm{c}$ per bu., 10 or more bu 65c. per bu. 


\section{KENTUCKY BLUE GRASS. \\ Shipped Direct to the Zimmerman Seed Co. from Fayette Co., Ky.}

Püre, genuine Kentucky Blue Grass stanđs without a rival for beauty and usefulness. As a lawn grass, nothing can equal 1t. As a permanent pasture. after once started it is easily the peer of any other grass. Our experience has been that stock of all kinds will keep in perfect condition when pastured on this famous grass. The most beautiful sight our eyes beheld, while traveling in Kentucky, was the Blue Grass Region, with its large fields of waving Blue Grass. For some years, we have been receiving letters from throughout the Great Southwest, asking for pure Ky. Blue Grass. It is claimed that the Blue Grass seed generally sold is not pure and some has lost at least a portion of its vitality. How true this may be we leave for you to say. WE decided to secure, if possible, a shipment of GENUINE BLUE GRASS Fayette County is situated in ihe center and heart of the Blue Grass Region of $\mathrm{Ky}$. We guarantee the stock we offer to have been raised especially for seed and shipped direct to us. Sow $14 \mathrm{lbs}$ to the acre for pasture, or about $60 \mathrm{lbs}$ per acre for lawn. Per pkt 5c., lb 25c., $3 \mathrm{lbs} 60 \mathrm{c}$, postpaid. By express or freight pk $60 \mathrm{c} ., 1 / 2 \mathrm{bu} \$ 1.15$, bu (14 lbs) $\$ 2.20,3$ or more bu at $\$ 2.10$ per bu.

a-NOTICE! Topeka is famous for its beautiful parks; and Every Park is Sown with Zimmerman's Grass Seed.

\section{QUICK GROWING LAWN GRASS.}

Our Special Lawn Mixture will insure a beautiful, compact, even sod. It includes the finest door or yard grasses, with a select proportion of $\mathrm{Ky}$. Blue Grass, etc. Full provision is made for successive growth, as to insure a rich green from early spring until late autumn. State if you wish the mixture to contain White Clover seed or not. Use one pound to 400 sq. feet of ground or $90 \mathrm{lbs}$ peracre. Our L,awn Grass is not "dished out of any old seed," but is carefully selected. It is not THE cHEAPEST, but IT IS THE BEST. Pkt 5c., $1 \mathrm{~b} 25 \mathrm{c}$., $3 \mathrm{lbs} 60 \mathrm{c}$, postpaid. By express or freight, 5 lbs $75 \mathrm{c} ., 10 \mathrm{lbs} \$ 1.40,25 \mathrm{lbs} \$ 3.25$.

RED CLOVER. Well and favorably known overywhere. Sow about $12 \mathrm{lbs}$ per acre. Lb 25c., 3 lbs $80 \mathrm{c}$ post-

WHITE CLOVER. Should be sown in all meadow mixtures, Useful to bee keepers affording honey of or freignt, 5 to $10 \mathrm{lbs}$ at $18 \mathrm{c}$ per lb. Special prices on larger quantities.

ALSIKE CIOVER. Is perennial and does not winter kill. One of the hardiest varieties known: it a sweet odor and makes excellent forage for bees. Sow 5 to 8 lbs per acre. A great favorite with bee keepers, as its flowers hav' a sweet odor and makes excellent forage for bees. Sow 5 to 8 lbs per acre. Bew are of "cheap" Alsike seed: seed is small and
hard to clean, much inferior seed containing a great assortment of weeds is generally offered at a low price. Dont plant weedsget our choice, well-cleaned seed. It pays. Lb 30c., 3 lbs $80 \mathrm{c}$, postpaid. By express or freight, pk $\$ 2.25,1 / 2$ bu $\$ 4.40$. bu (60 lbs) $\$ 8.75$.

BOHARAH Or SWEET CLOVER. G rows 4 to 6 feet high and produces abundanee for bees. Sown in spring at ratc of $10 \mathrm{lbs}$ per acre. Lb 25c., $3 \mathrm{lbs} 65 \mathrm{c} .$, postpaid. By express or freight, pk $\$ 2.00$, bu (60 l bs) $\$ 7.50$

PEARI MIILET. This variety known for years as Pearl Millet or Cat Tail Millet has recently been called time and has slender stalks and long blades. Cut stalks for green fodder when 3 feet high and get a second growth for ensilage. Sow in drills 3 to 4 feet apart, 3 to 4 lbs per acre, Broadcast 8 lbs per acre. Pkt 5c.; 1b 20c., postpaid. By express or freight 6 to 10.1 bs at $10 \mathrm{c}$ per $1 \mathrm{~b}$ : : over $10 \mathrm{lbs}$ at $9 \mathrm{c}$. per $1 \mathrm{~b}$.

TEOSINTE. Relished by sheep, horses and cattle. In the South as many as 5 cuttings may be had. Plant in

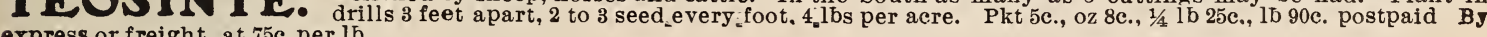
express or freight, at $75 \mathrm{c}$ per $1 \mathrm{~b}$

FLAXISEED. Sow 25 to $301 \mathrm{bs}$ per acre. Pkt 5c., 1b 20c., 3 lbs 55c., postpaid. By express or freight, pk 00e.,

BARLEY. CHAMPION BEARDLESS---A new beardless barley and the earliest known, Six-rowed, is entirely MANSURY--A six-rowed barley, with long, heavy, well-filled heads. Peck 35c., 1/2 bu 60c., bu $\$ 1.10$.

SEIECTED OATS. RED TEXAS--A heavy yielder and sure cropper, and is rust-proof. More gen\& or more bu at 6nc per bu.

WHITE RUST PROOF---Stands up well, has thin hull and heavy meat. Cannot be snrpassed in the oat field. A grand White Oat that can be depended upon at all times. Per bu $75 \mathrm{c} ; 3$ or more bu at $60 \mathrm{c}$ per bu.

KHERSON--A good variety and largely advertised in the West. Per bn 75 c., 3 or more bu at $60 \mathrm{c}$ per bu

IPANESE BUCJTUTTAT. This has become one of the most popular productions in this grown. Kernals easily double the size of others. Pkt 5c., lb 15c., postpaid. By express or freight, pk50c, $1 / 2$ bu $80 c$., bu $\$ 1.50$. 2 or more bu at $\$ 1.40$ per bu. 


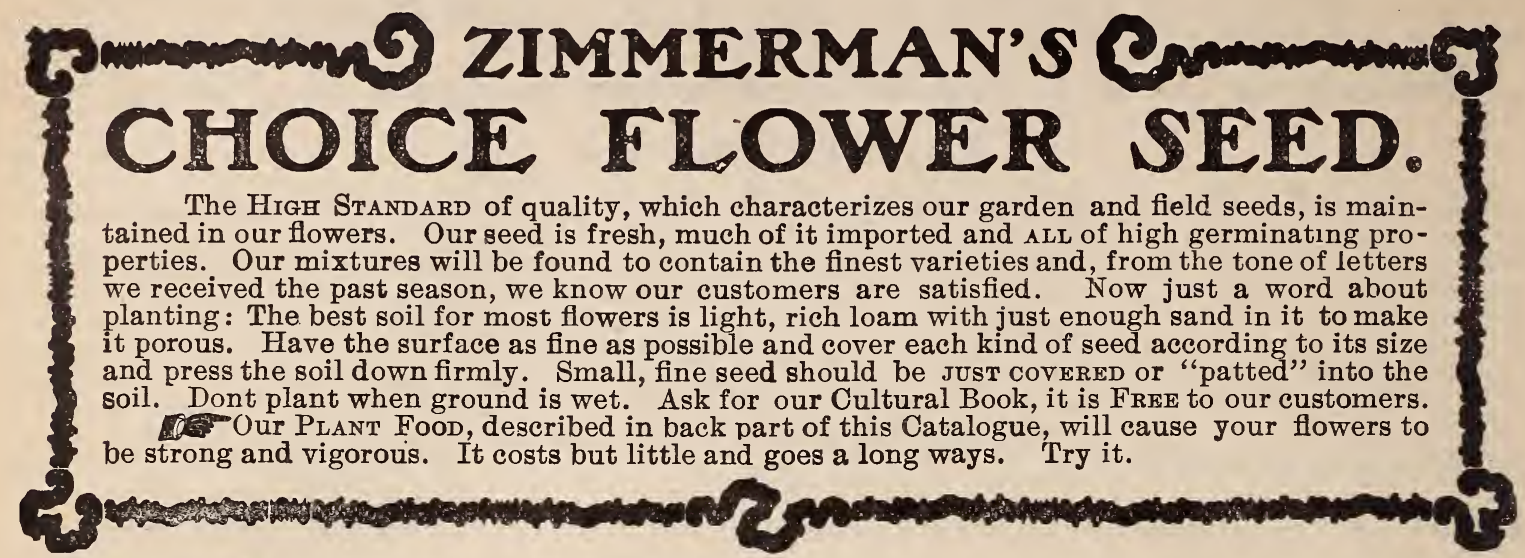

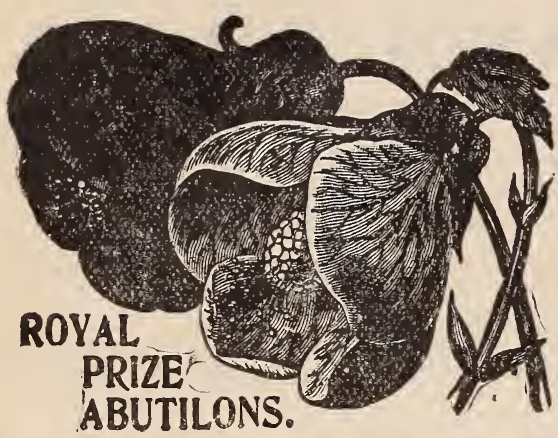

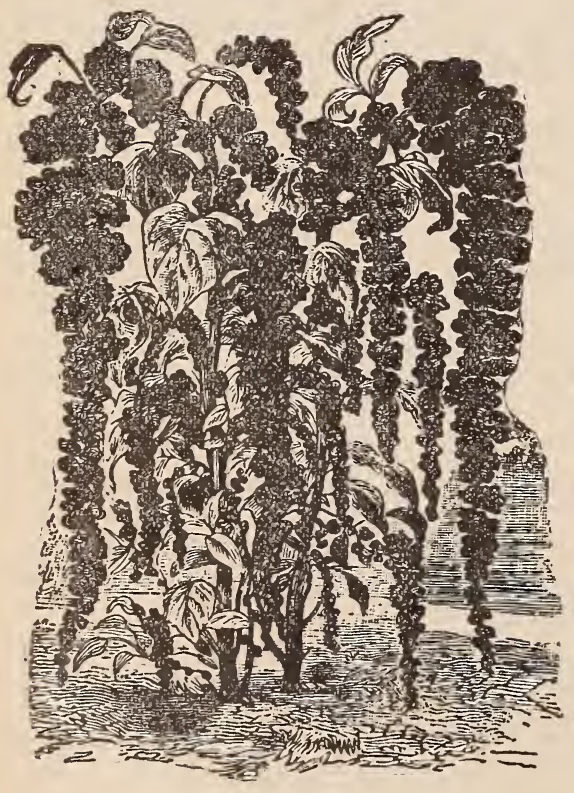

AMARANTHUS.

\section{Abutilons.}

ROYAL PRIZE MIXTURE - These beautiful fiowers are admirably adapted to both house and out door culture. They form bushes bearin bell shaped blossoms. They are rapid growers and very easy raised from seed If given an early start indoors and transplanted in the garden when the weather is settled. TRY THEM. Extra choice mixed. Pkt. ‘s. ABUTII.ON-Good mixed. Pkt. $5 \mathrm{c}$.

\section{Alyssum.}

LITTLE GEM - These dainty dwarf, fragrant white flowers need no introduction, as they are so It is of easy culture and the finest variety of Alyssum. No flower garden is complete without it. Large pkt. 5c.; oz. 35c.

BENTHAMI COMPAC TUM - Commonly called Tom Thumb on account of its dwarf, robust growth. Excellent for $30 \mathrm{c}$.

\section{Antirhinuma (SNAP DRAGON)}

One of the old fashior favorites so desirable for i.s variety of colors and free blooming. Blooms heavy frost and if covered over with leaves, will survive and continue their blooming the second year.

BEST TALC MIXEDPkt. 5c.

A maranthe CAUDATS (love lles bleeding) their long red panicles. They are one of the most ornamental anu beatiful plants of the Amaranthus family. Pkt 5c.

SPLENDENS (rainbow plant)-These are noted for their hand some foliage, inm- foliage dark branze tip ped with green; the outer fo liage. wh. exposed to light becomes gorgeous crimson and gold Pkt 5c.

MLXTU:- Contains the above varietles and many more. Pkt. 5c.

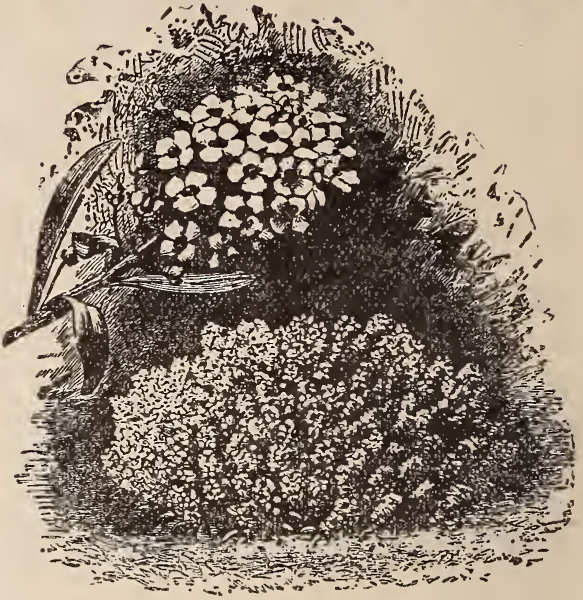

LITTLE GEM ALYSSUM.

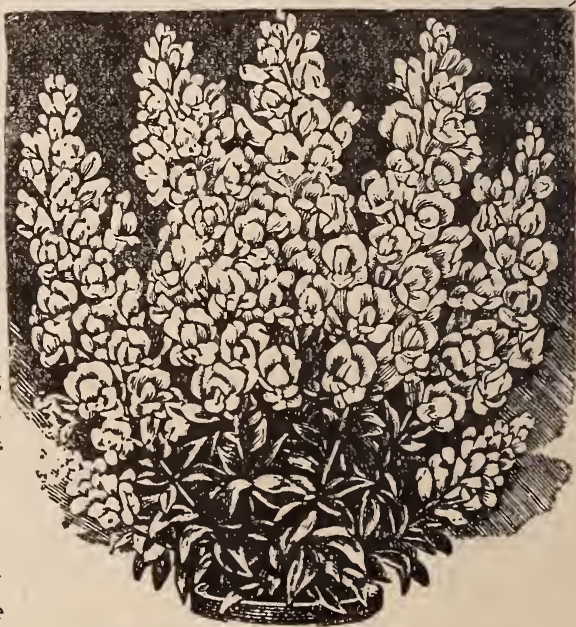

ANTIRRHINUM.

A beautiful hardy annual. The flowers are bush-like, rescmbling an inverted tassel and axe excel. - Seratum. lent for garden and winter blooming in the house. FINE Mixed, pkt $5 c$. 
WHITE BRANCHING-Th is Aster is easily grown from seed, bearing magnificent white flowers from two and one-half to four inches in diameter, has long stems, making it admirable for cutting. It will be necessary to see them growing to appreciate the:r real beauty. We have the choicest strain. Extra large Pkt 10c.

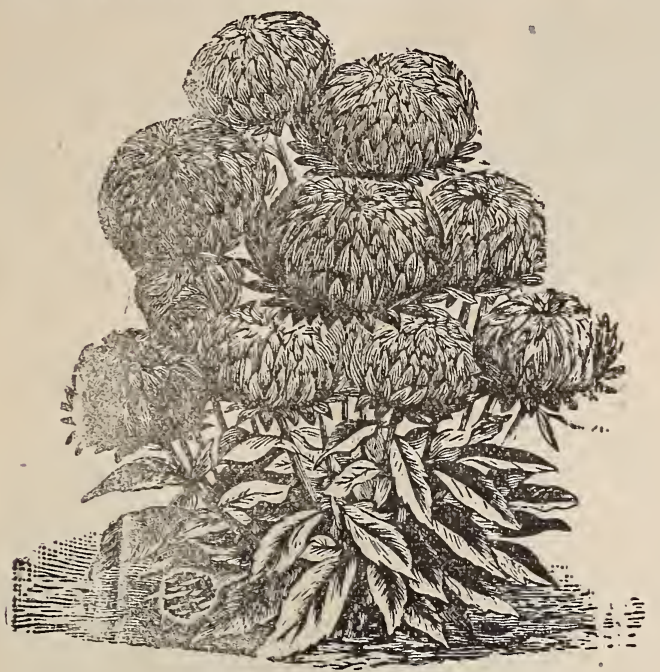

PEONY FLOWERED.

TRUFFAUT'S PEONY FLOWERED - Plants grow from 18 to 24 inches high; have long wiry tems, bearing large fowers 3 or 4 inches in diameter, very double and shaped like a paeony. Mixed colors. Pkt (100 seeds) 5 :.

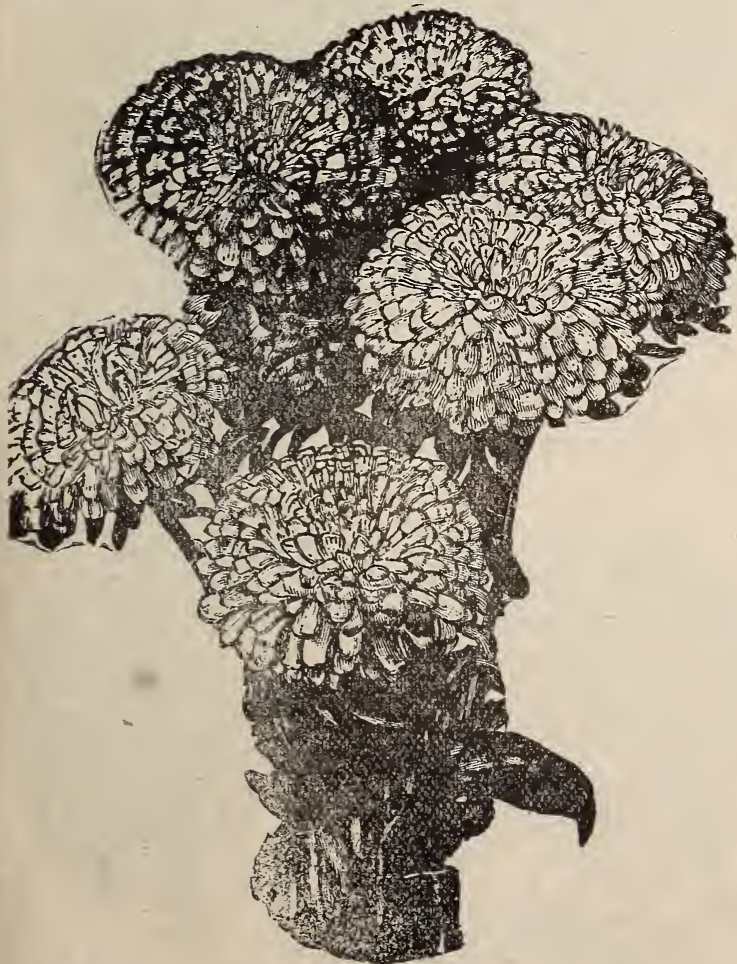

VICTORIA-This is unques stionably a very handsome variety of Aster. We have a n t. Flowers are immense, growing one and three-fourths
feet high, globular shape and critical lover of shape and very double: The most say the least. " Mixture oontaining all colors. Pkt " to

MARY SEMPLE-A soft shade of rosy flesh color. borne upon long stems, plants grow two feet high, flowars very double. Extra large pkt $10 \mathrm{c}$.

\section{ASTRS.}

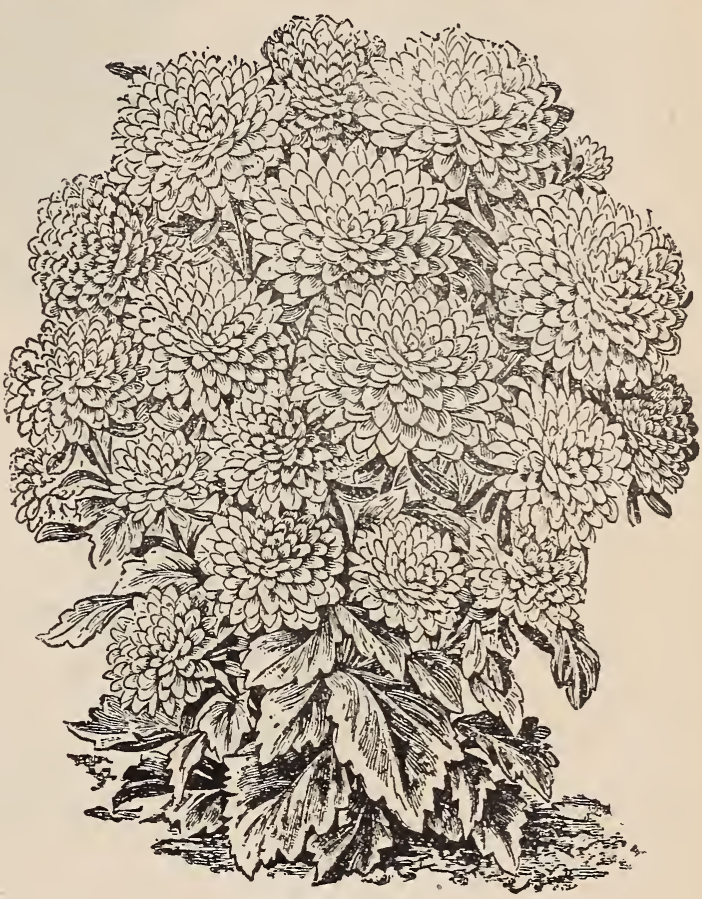

QUEEN HELEN.

QUEEN HELEN-This grand Aster is something entirely new, never having been off ered before and has unusual merit. It is tall, of branching habit very delicate, rogy tinted. The petals are long and inclined to curve giving it a resemblance to a fine species of Chrysanthemun. This is the cream of the Aster familv. Don't fail to inelude a pkt in your order. We control the supply. Pkt 15s; 2 for $25 \mathrm{c}$.

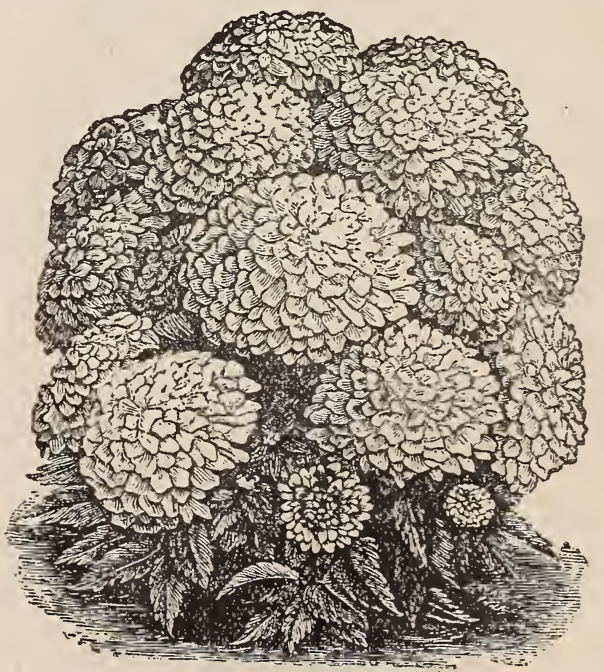

DWARF QUEEN MIXED-Most excellent for pot culture, as well as for bedaing. Flowers are extra large size, very double, excellent for cutting. Pkt 5c. COMET-Under good cultivation these plants shoule grow 12 to 15 inches in height. It is of branching habit, each stem producing a fine flower. The outer petals are broad, flat and curving. while the inner ones are compact and pointed at the colors. Pirt (100 seedn) $5 c$. 


\section{Carnations}

'The New Marguerite and Giants of CALIFORNIA are well-known as th very finest Carnations. Our seed is the very best to be obtained and is all new stock. Please do not compare our superior seed with the cheap inferior grade sold by some, We have ONLY THE BEST

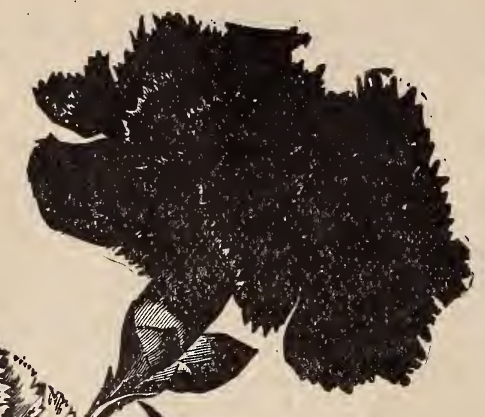

MARGUERITE-Though universally admired, few know how easily these lovely flowers can be raised from seed. They flower in four months from time of sowing. They are of vigorous, dwarf, erect growth, requiring no supports. Very hardy. You. will be greatly pleased with our fine mixture, which includes all colors. Pkt (75 seeds) 5c.

GIANTS OF CALIFORNIA-These are of dwarf, bushy habit. This grand new strain will be sure to please, on account of its hardiness and abundance of brilliant fragrant bloom. Seeds are very scarce. We can supply finest mixed. Pkt (50 seeds) $10 \mathrm{c}$.; or 2 for $15 \mathrm{c}$.

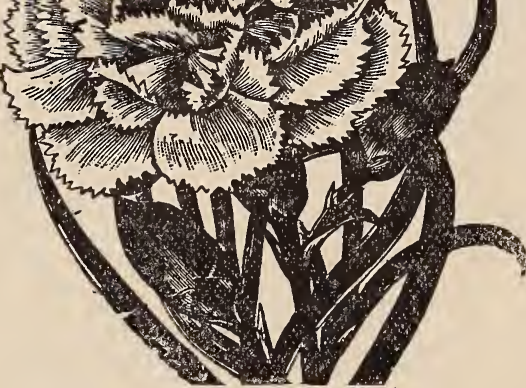

For Carnation Plants, Coleus and Fuchsia Plants See Plant Dept, Page 56.

\section{CINERARIA.}

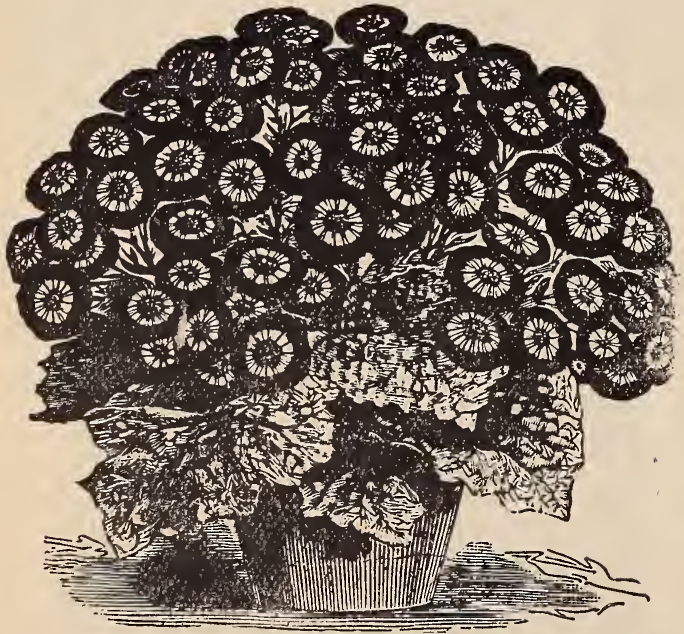

HYBRIDA FINEST MIXED-One of the cholcest of plants for house culture, seeds germinate quickly and plants are soon covered with flowers of exquisite satiny hue. We know of few plants more desirable. In this mixture is every lovely color to be had Pkt (100 seeds) 10c.

\section{CELOSIA.}

DWARF FEATHERED-This is especially desirable for both bedding and pot culture. It resembles an ostrich plume because of its graceful nodding plumes above the follage. They greatly please lovers of the beautiful. Feathered varieties in finest mixture. Pkt $6 \mathrm{cts}$.

TRIUMPH OF THE EXPOSITION-The beautiful bronze follage and brilliont scarlet bloom of this handsome plant is similar to that of Scarlet Sage, but it is more desirable because of its early flowering qualities, and its continuing to bloom until heavy rost. Plst 5c.

\section{BIRD OF PARADISE.}

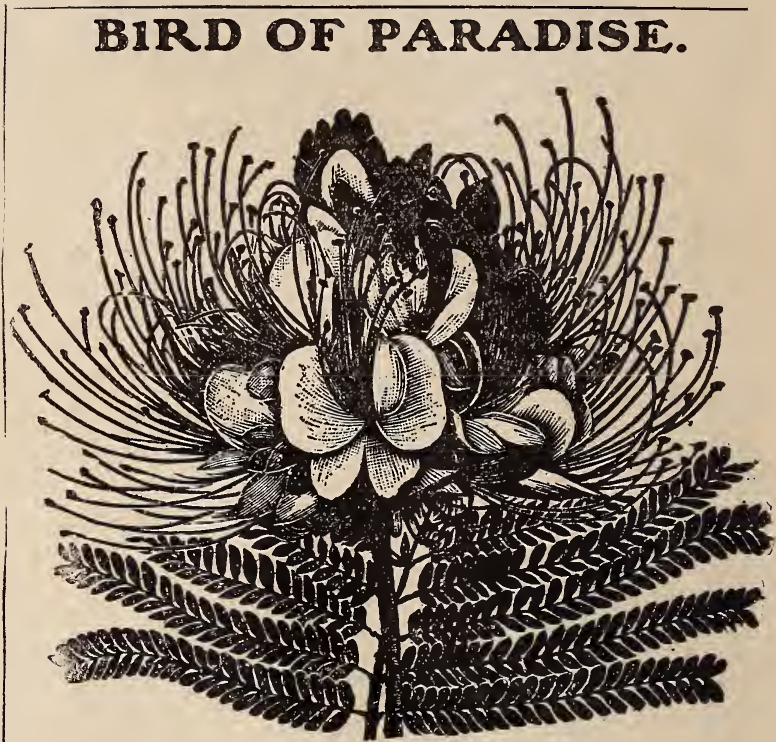

This is truly a novelty, being one of the most interesting plants in cultivation. The flower is yellow and is spread out in fan shape and add greatly to the decorative qualities of the flowers, as does its beautiful foliage. No description can do it justice-it must be grown to be appreciated. Pkt 5c.

\section{CHOICE BALSAM.}

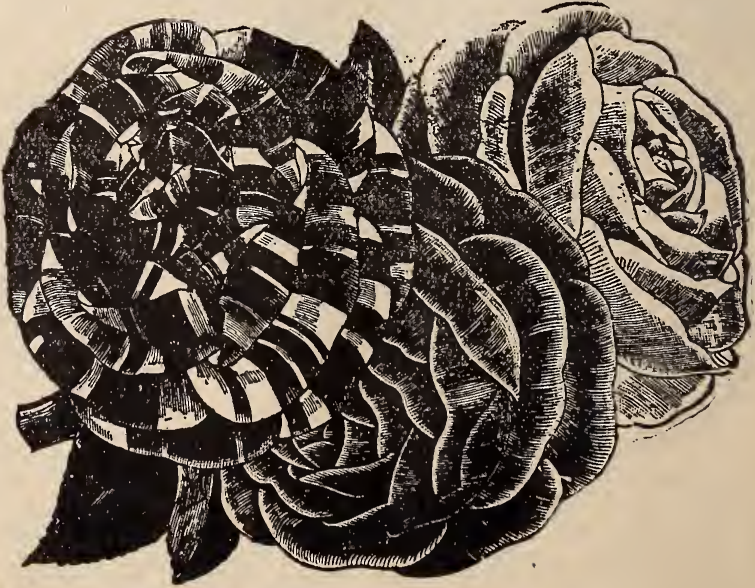

CAMELIA FLOWERED MIXED-These are one of our speclalties and we know we have as fine seed as it is possible to procure. Flowers are extremely double, very large and bear a striking re semblance to a miniature

Scarlet-Plst 8c. produced in trusses. Large $p$ istils of a rich crimson color Camelia. Comprises all the different colors. Pkt 5c.

White-Pkt 8c. 


\section{DAHLIAS@}

DOUBLE FLOWERING DAHLIAS-It is generally supposed that Dahlies will not grow from seed and bloom the first year. We offer seeds plant out doors, will produce an abundance of bloom by fall. Our seed is from the best collections in Europe and embrace all the various kinds, such as Show, Pompon, Cactus and Lilliput varieties. Lf you want much delight at little expense try our Dahlias. Pkt 5c.

TOM THUMB-These grow from 12 to 15 inches high and are covered with showy single flowers. Of easy cultivation. We offer the mixed colors. Plt (5u seeds) 5c.

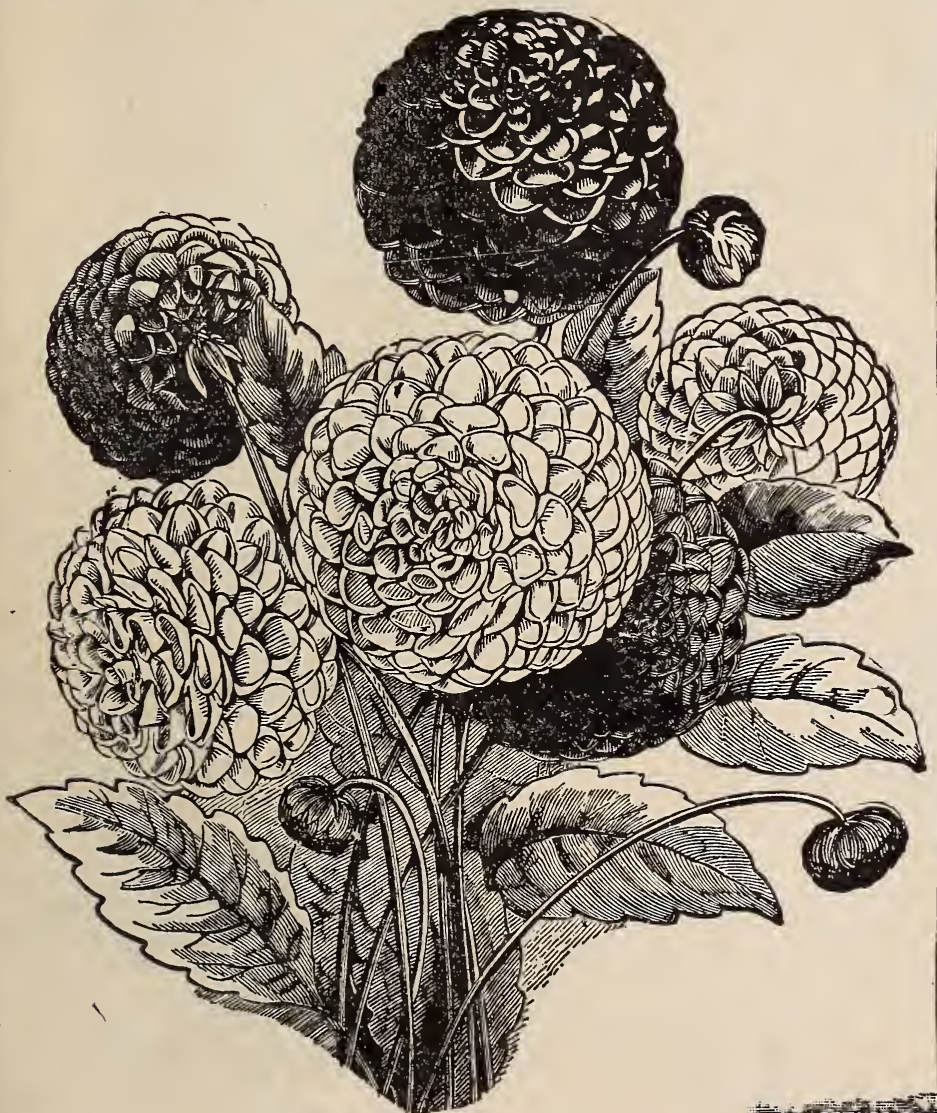

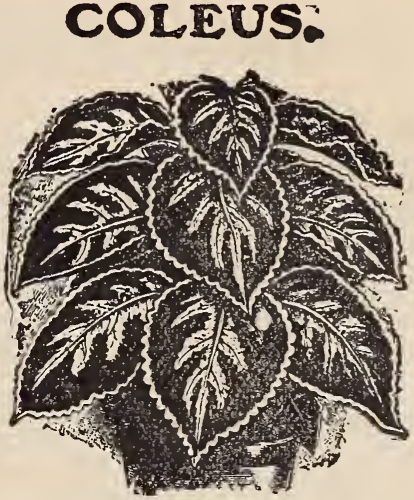

The grandest foliage plant to be had from seed. plants are from 2 to 3 feet high, leaves are broad and long, comprising all the shades of yellow, red, green, from the darkest to lightest. 'Of easy culture; in rich soil given plenty of water. Pkt. (100 seed) $10 \mathrm{c}$.

\section{FOR-GET-ME NOT.}

These dainty little flowers are too well known to need any description. Grow 6 or 7 inches high, are covered with delicate blue flowers.

ALPESTRIS-Blue and white dwarf, free flowering. Pkt 5c.

ELIZA FONROBERT-Flowers are of a sky blue color, with yellow eye. Pkt. 5c. SEMPERFLORENS-Blue, very early to flower. Pkt. 5c.

\section{FEVEREEW.}

GOIDEN-Very hardy, free lowering perennial plant: if sown early will produce flowers by fall. Plants throw up stems, ending in clusters of flowers; foliage has a ferny appearance
good for bouquets. Pkt. $5 \mathrm{c}$.

\section{CENTAUREA.}

NEW DOUBLE-The old-fashioned double bachelorr buttons, which have alwars been favorites. Are attractive hardy annuals; flowers are very double and many colors. Pkt $5 \mathrm{c}$.

CYANUS-Free ilooming. Sometimes called "Blue Bottle," "Korn Blume," etc. Choice mixed colors, pkt $5 \mathrm{c}$.

\section{COSMOS.}

These beautiful, dainty, graceful flowers are becoming more and more popular as the years go by. The follage is very feathery and ferny like. while the broad, deep petals, with its yellow heart, rise on long stems from it. We have the early flowering strain, which produces an abundance of bloom from July to November.

WHITE-Pkt. 5 cts.

PINK-Pkt. 6 cts.

MIXED-Comprising every color. Pkt. 5 cts.

\section{ESCHOLTZIA.}

(Calirornia Poppy.)

These handsome flowers gain praise and admiration wherever cultivated. Flowers are of various forms, some flat, some cup-shaped, others deep with flaring edges. OUR SPECIAL MIXTURF contains many rare shapes, double and single such as "Glory of the West," "Rosy Morn," "Douglasi," etc. Pkt. 5c.

\section{FUCHIAS.}

These succeed best as pot plants, though in southern states are hardy enough for outdoor planting. During

hot seasons, keep in shady place.
DOUBLE AND SINGLE MIXED-Pkt 20 c.

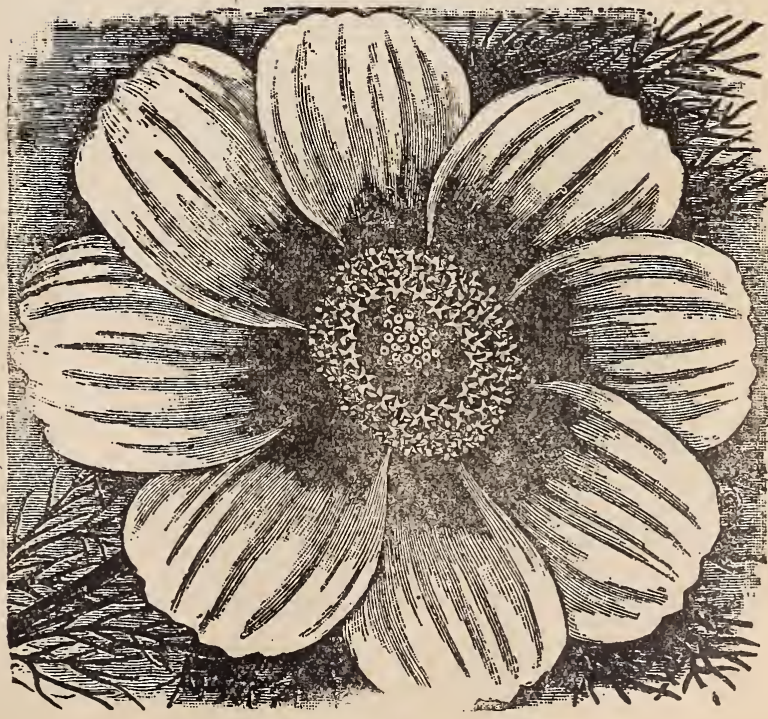

COSMOS 


\section{DIANTIUS (Chinese Pink)}

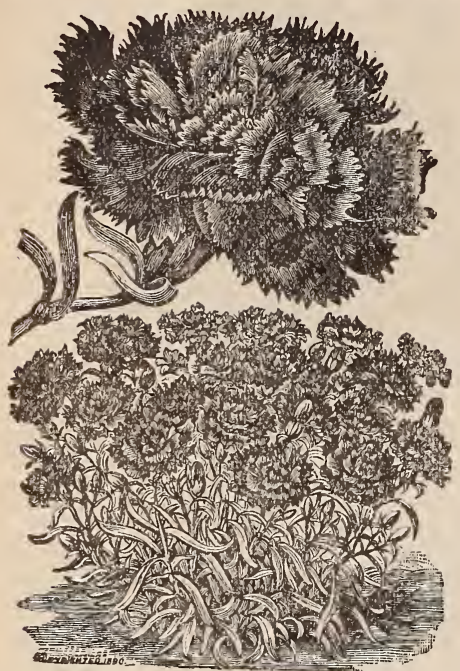
ous. Pkt. 5c. white with deep pur
red center. Pkt 5c. much larger. Pkt 5c.
DWARF FIRE BALLYou will find these to be dwarf, compact in growth petals fringed, deep red and very double. Sure to please the most fastidi-

THE BRIDE-Handsome single flowers, pure white with deep purplish-

CHINENSIS (Double Chinese Pinks)-Contain many distinct and beautifully marked varieties of rich and numerous colors: may be described as resembling Giant Sweet William, except they are

Our seed is all new and of the best quality. Our seed will please you

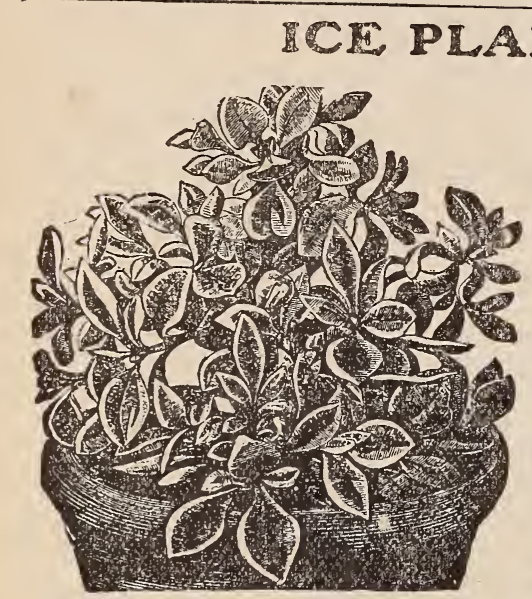

ICE PLANT.

\section{MIGNONETTE.}

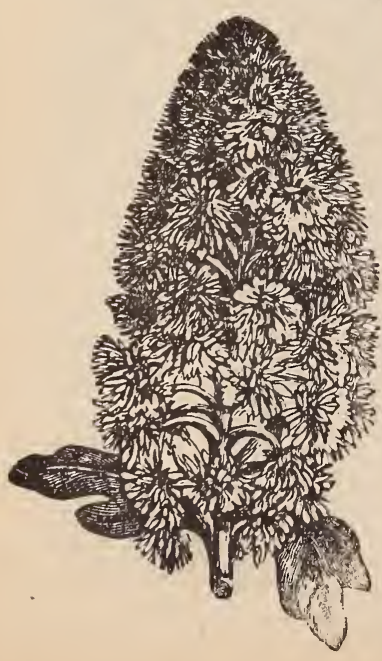

NEW GOLDEN MACHETThis kind is prized for its frafrangrance and earliness. It grows rapidly and produces an abundance of spikes of flowers while it is yet cold weather, continuing to bloom through the summer. It is a delicate shade of lemon; foliage dark green. Pkt 5c.

IMPROVED SWEET MACEHET-Pkt 5c.

MIGNONETTE MIXED-This is the best mixture. In ordering do not overlook this. Pkt $5 \mathrm{c}$.

\section{Hollyhock.o}

GIANT DOUBLE MIX D-As

fine and beautiful as the most double rose. The plants grow 4 to 6 feet in height and produce spikes of rosette.like flowers of every shade and color. Pkt 5c.

\section{CANDYTUET.}

This hardy annual grows with very little ca $\bar{\theta}$, in most any kind of soil. Produces plants sev in to eight inches tall: maires a fine border. No:hing quite so satisfactory for the little eare it thquires. We have very choice varieties for boquets.

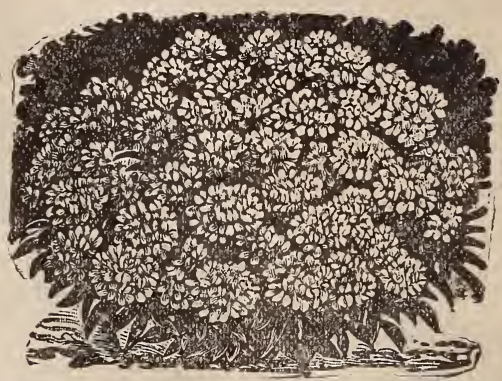

DWARF OR TOM THUMB-- Which may be sown at intervals of two or three weeks and be Will have continuous bloom throughout the season. WHITE OR SNOWFLAIE-Pkt $5 \mathrm{c}$.

MIXED COLORS-All sorts mixed. Pkt 5c.

\section{CHR INANTHIMUM.}

YELLOW (Coronarium)-A new color, very sof shade of lemon, quite desirable, they are very sof maise lovely flowers for boquets. Pkt $5 \mathrm{c} ; 1 / 2$ oz $25 \mathrm{c}$ WHITE - These furnish double snow white flowers through the summer and fall. Grow two ft. high. Pkt $5 \mathrm{c} ; 1 / 2$ oz $25 \mathrm{c}$.

DOUBLE ANNUAL Our seeds are sure, if carefully sown in February or March, to produce a profusion of bloom early in the fall. This sort includesmany colors not listed and a re This sort of the finest sorts. We want our customers to try a packet of these on our recommendation. Pkt (100) seeds) $10 \mathrm{c} ; 3$ for $25 \mathrm{c}$.

\section{CONCOMB.}

QUEEN OF DWARFS-This is not the common sort usually offered, but something new. Bears large crimson combs; is very dwarf in habit, mak. ing it fine for borders. and handsome for potting. FINEST MIXED-All the finest and best. Pkt 5c.

$$
\text { GAILLARDIA. }
$$

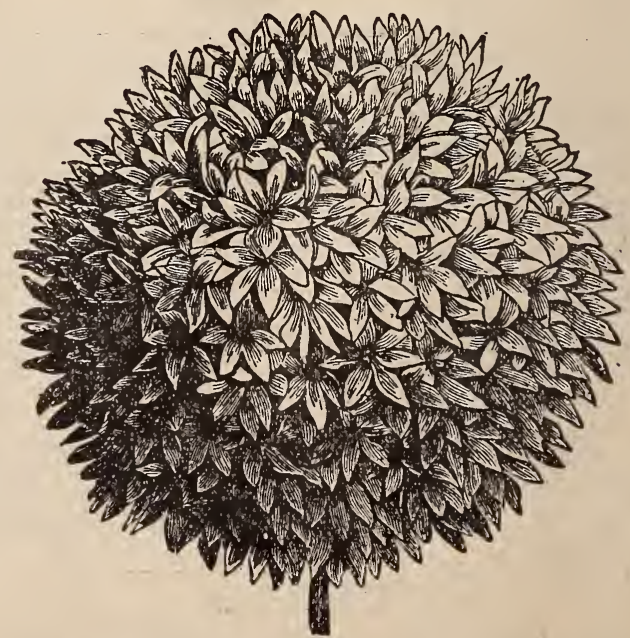

GAILLARDIA-Of magnificent size and color, very double, borne on long stems, making it excellent for cutting, will keep over a week when cut Plt 5c. 


\section{CANNA SEED.}

These beartiful flowers can be easily grown from seed and will bloom the first summer, if sown by April, and if carefully potted in the Fall, and kept in the house will bloom all Winter. Our Giant Mixed has been saved from the choicest Cannas of our own growing and will produce a grand assortment of the finest varieties. Pkt 5c.

a.For Canna Bulbs see page 54 .

\section{DATURA. (Trumpet Flower)}

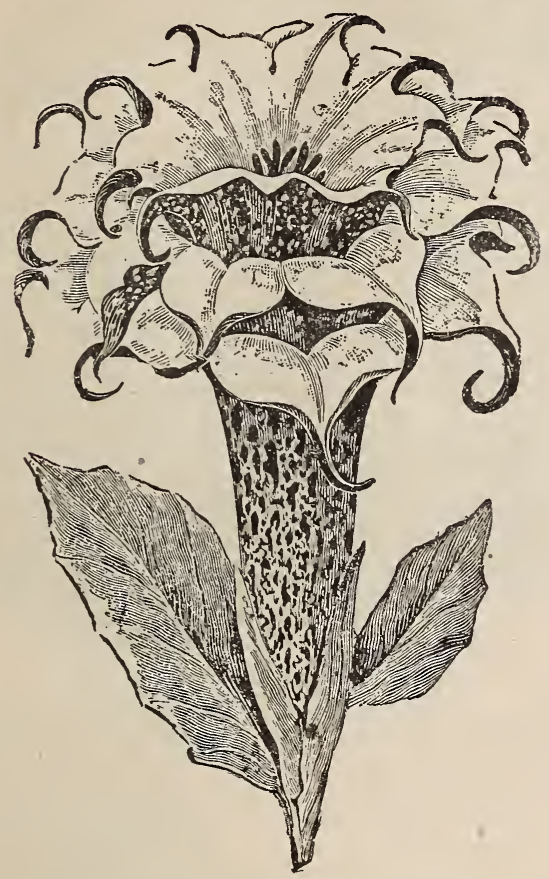

DOUBLE MIXED-Bloom freely the flrst year and are very showy. Flowers measure about 8 inches long and 4 to 5 inches across the month and are very fragrant. Roots may be taken up in the Fall. Pkt 5c.

\section{HELIOTROPE.}

A half hardy perennial, which is easily grown from seed. FINE MIXED-This contains the choicest variectie and will bloom the entire season, Pkt 5c.

\section{LOBEIIA.}

The dwarf and free flowering qualities of these make them especially suitable for rockeries, pots, edging flower beds, etc. Dark blue, white rich bright blue, mixed. Pkt $5 c$.

\section{MARVEL OF PERU. \\ (FOUR O'CLOCK.)}

Very easily grown, yet one of the most pleasing of the old fashioned flowers The open ing of the fragrant and brilliant blossoms make it a grand sight each afternoon, Every conceivable color in this mixture. Pkt 5c.

\section{GERANIUMS.}

The only way to obtain new and original varieties is through propagation of seed.

SINGLE MIXED-Best single varieties. Pkt 5c.

DOUBLE MIXED-Fine double fiowers of choicest colors.

\section{MARIGOLD.}

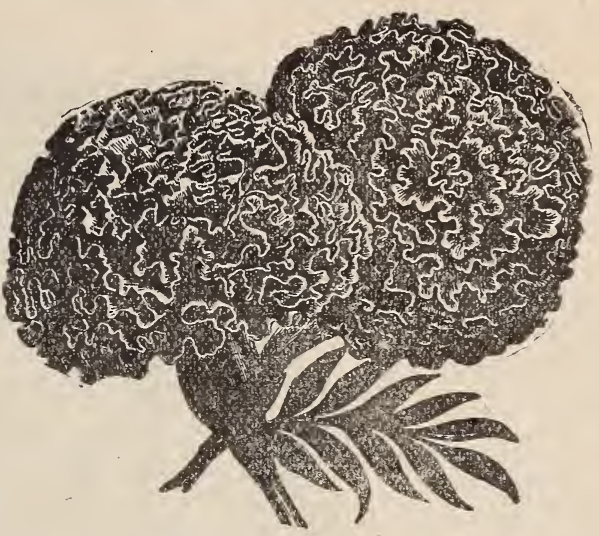

LEMON $Q$ UEEN-The flowers are very double to the center, an inch in diameter and cover the plants profusely. Of a lovely shade of rich cream and tint of lemon. Pkt oc.

AFRICAN DOUBLE MTXEU-African vari eties are stronger in habit and prodnce larger flowers. All varieties mixed. Pli $5 \mathrm{c}$.

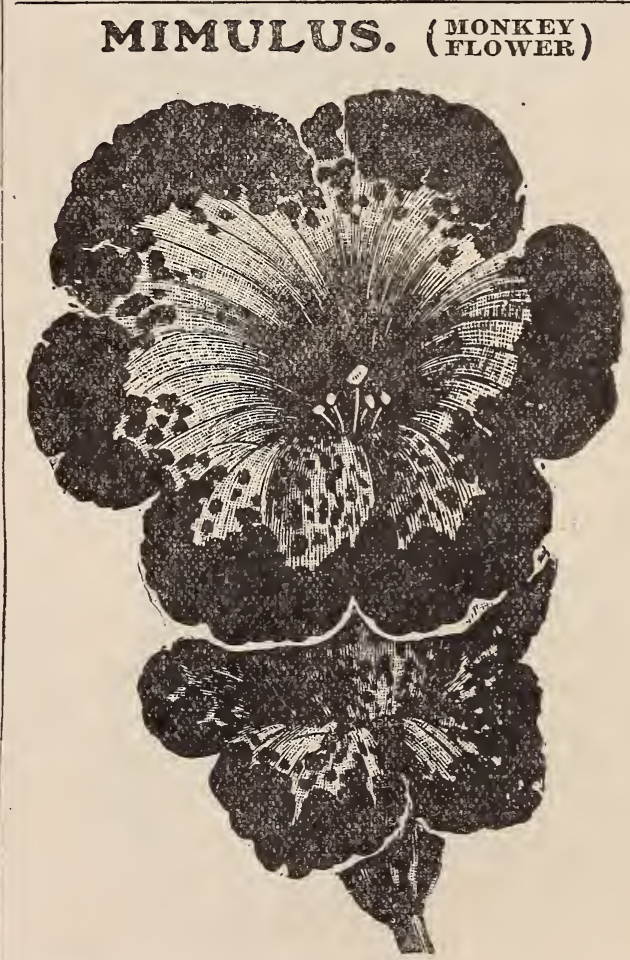

TIGRINUS-If you want something lovely for baskets and vases, select this excellent variety. It is half hardy, thrives well in open culti-jation, if given plenty of shade. It is famous for 1 ts rich and beautifully blotched and singularly shaped flowers and tender fo-

\section{COMPLETE FLOWER GARDEN FOR 25c.}

We offer the following 15 packets for only $25 \mathrm{c}$ postpaid. A regular 75c collection. All are easily grown from seed and you will find this will make a most gorgeous flower bed:

Aster, Fine Mixed. Alyssum, Little Gem, beautiful pure white. Carnations, New Marguerite, grand mixture. Candytuft, Fine Mixed, Cosmos, Fancy Mixed. Larkspur, Finest Mixed. Mignonette, All the Best Mixed. Nasturtium, Grand Mixture. Portulaca, Choice, All Colors. Pansy, Grand Mixture of Giant Varieties. Petunia, Fancy Coloss, Grand Display. Phlox, Finest Mixed, Elegant Assortment. Poppy, All Sorts and Colors. Sweet Peas, Our Select Mixture of the Finest and Best. Verbenas, Fire Collection of Mixed Colors. 


\section{Zimmerman's Nasturtiums.}

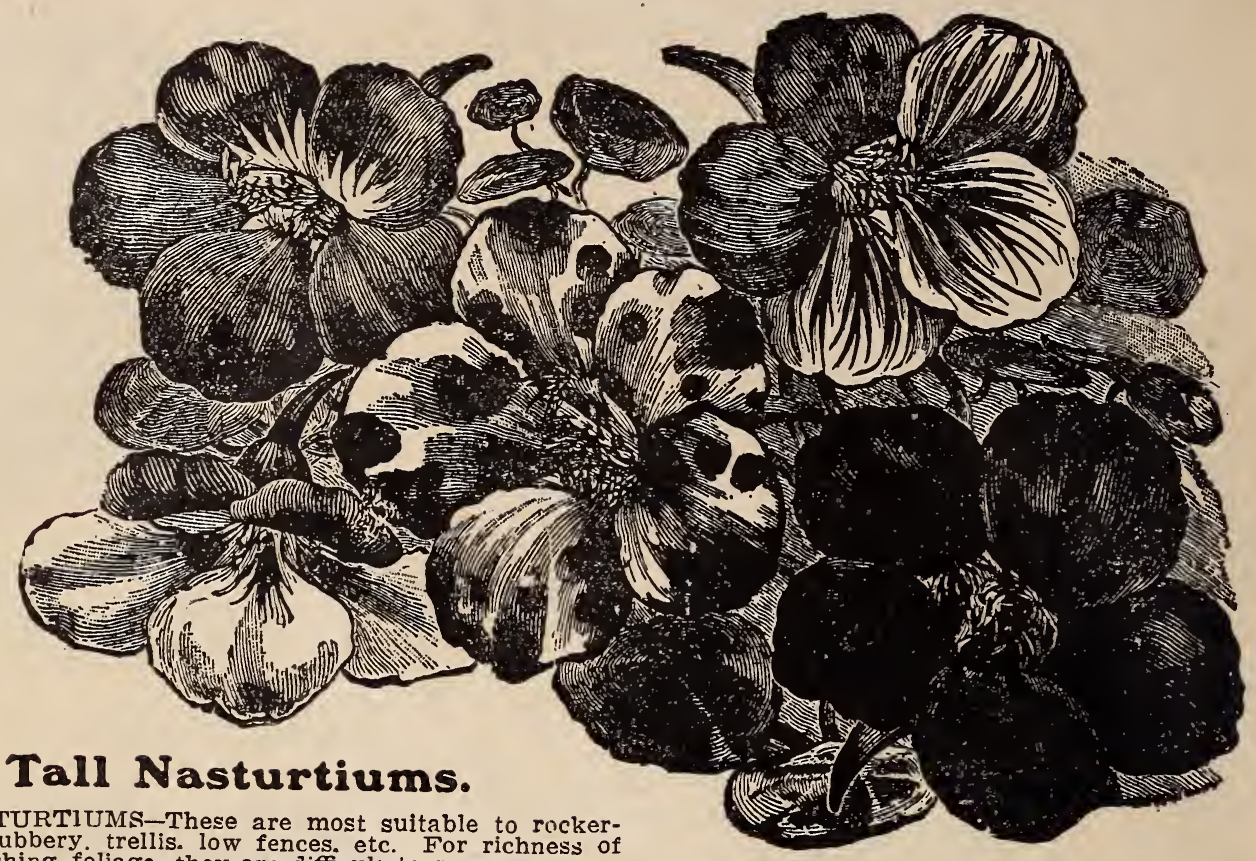

TALL NASTURTIUMS-These are most suitable to rockercolor and refreshing foliage, they are difficult to surpass.

HYBRIDS OF MADAM GUNTHER-These are difficult to excel in richness of color. They are climbers and continuous bloomers. It is impossible to describe the many colors; as near as we could come to it would be to say, there is scarcely a tint or shade in a brilliant sunset not represented among these. Pkt $5 \mathrm{c} ; \mathrm{oz} 10 \mathrm{c} ; 1 / 4 \mathrm{lb} 35 \mathrm{c}$.

DARK CRIMSON-Deep velvety red, or brownish red. Pkt 5c; oz 10c; $1 / 4 \mathrm{lb} 35 \mathrm{c}$.

SCARLET - Flaming red. Pkt 5c; oz 10c; 1/4 lb $35 \mathrm{c}$.

TALL MIXTURE-Comprising every known color. This is one of the best. Pkt 5c; oz 10c; $1 / 4$ lb $35 \mathrm{c}$.

Trailing Nasturtiums. growers. Pkt $5 \mathrm{c} ;$ oz $10 \mathrm{c} ; 1 / 4 \mathrm{lb} 35 \mathrm{c}$.

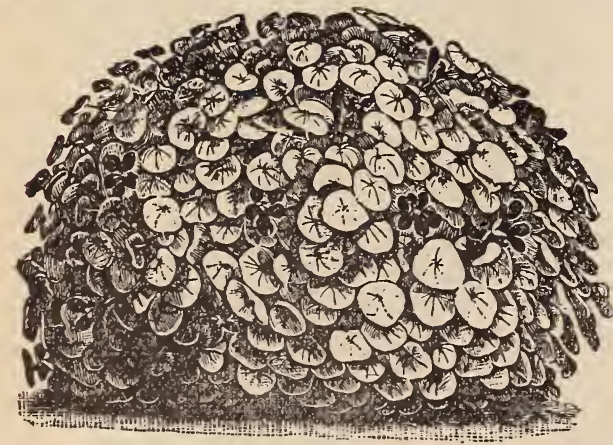

NEW TOM THUMB NASTURTIUM-CLOTH OF GOLD.
LOBB'S TRAILING - In these will be found all the choice colors; desirable for freedom of bloom. Winter blooming, rapid

\section{Dwarf Nasturtiums.}

SELECT DWARF MIXED-This is our specially prepared mixture of all the dwarfs. They are compact and bushy, follage of both dark and light type, colors very bright and pleasing, making them very effective. We heartily recommend them. Pkt 5c; oz 10c; $1 / 4$ lb $35 \mathrm{c}$.

BEAUTY - Gorgeous red and orange. Pkt 5c; oz $12 \mathrm{c} ; 1 / 4 \mathrm{lb}$ $45 \mathrm{cts}$.

PEARL-Clear tint of lemon, fading to a primrose. Pkt 5c; oz $12 \mathrm{c} ; 1 / 4 \mathrm{lb} 45 \mathrm{c}$.

PRINCE HENRY - Is o ne of the most distinct and charming variet:es, delicate tints of rose and straw color. Pkt $5 \mathrm{c}$; oz $12 \mathrm{c}$; $1 / 4 \mathrm{lb} 45 \mathrm{c}$.

CLOTH OF GOLD-This is of compact growth, with bright golden yellow leaves and brilliant scarlet flowers, Pkt 5c.; oz 15c.; $1 / 41 \mathrm{~b} 50 \mathrm{c}$.

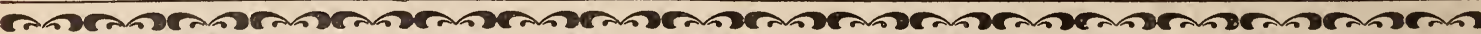 A Home Made Beautiful for \$1.00.}

We will send our 25c Flower Seed Collection, (described on page 45) and will add 1 pkt Wistaria, 1 pkt Cypress Vine and the following choice bulbs: 3 Madeira Vine Tubers ; 3 Tuberose Bulbs ; 3 Assorted Cannas; 6 Gladiolus bulbs; 12 Oxalis bulbs This Grand Collection of 17 regular size flower seed packets and 27 choice bulbs sent postpaid for only \$1.00.

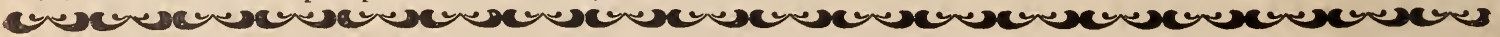




\section{PANSIES-A Page of Giants.}

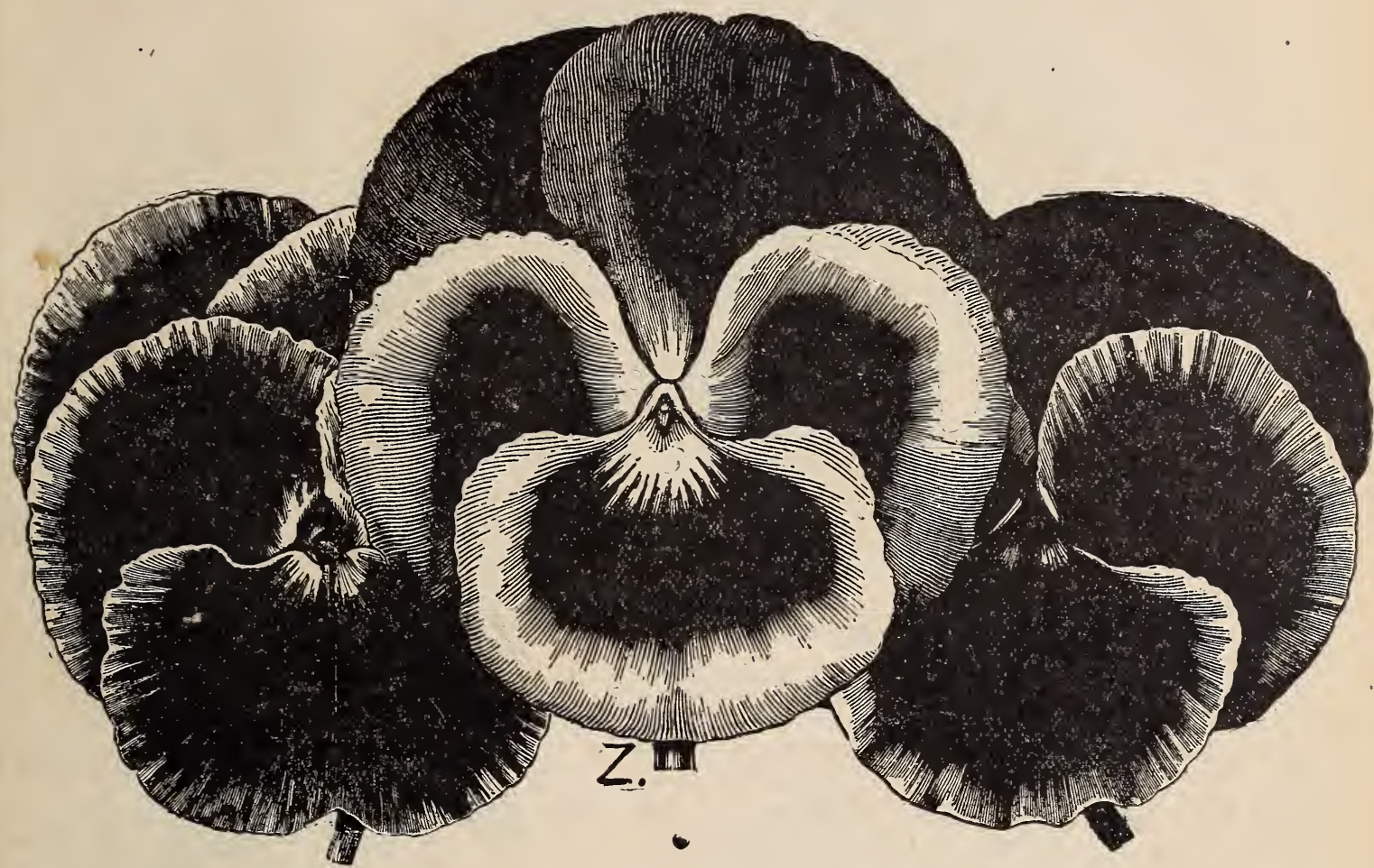

\section{Zimmerman's Imperial German.}

These varieties were imported by us direct from Germany and are the Finest in the World

SNOW QUEEN-Very fine A puresating Whict Plit 5c

YELLOW-Distinct Aariety Pkt óc

PURPLE MANTLE-A deep rich purple. Pkt 5c.

RED RIDING HOOD-Several shades of flaming red. Pki 5c. VICTORIA RED-Pretty shade of irimson. Pkt 5c.

PURPLE-Deepest shade of purple known. Pkt $5 \mathrm{c}$

FINEST MIXTURE-We scarcely know how to give a perfect description of these extra fine strains, because we know it will be hard to do them justice, suffice it to say, all the above and fifty others are contained in it. Finest in existence. Pkt 5c; 3 for 12c, $2 / 2$ oz $75 c$., oz $\$ 140$, postpaid

\section{Other Select Varieties.}

We supply our customers with as good Pansy seed as can be found in America or Europe. A trial will convince you.

KING OF THE BLACKS-Flower almost coal black, very velvety. The black sort is considered one of the finest by the most critical. Pkt 5c.

SILVER EDGE-Dark purple, silver border. Pkt 5c.

PRINCE BISMARCK-Beautiful shades of brown and goldenbronze, marbled. Pkt $5 \mathrm{c}$.

PHEASANT'S EYE-Upper petal sky-blue with violet edge lower ones mottled and variegated. Pkt $5 \mathrm{c}$.

FAUST-Deep jetty black. Pkt $5 c$.

PANSY MIXTURE-This is our special mixture of all the best known varieties, each strain is exceptionally fine for bedding, and oz 900 , postpaid.
SWEET SCENTED.

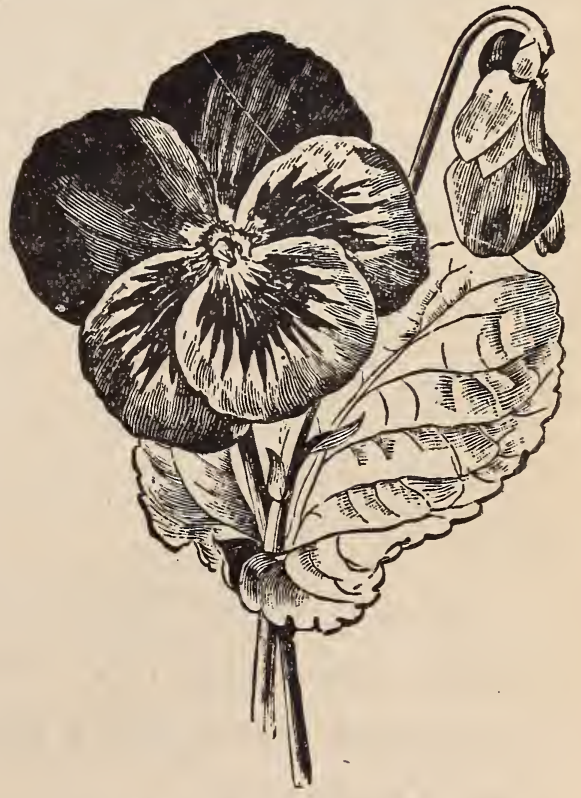

SWEET SCENTED-This is the result of crossing the Pansy with the Sweet Vlolet. Very fragrant, large and have great diversity of color; possess the hardiness of Violets. Pkt 10c: 3 for $25 \mathrm{c}$. 


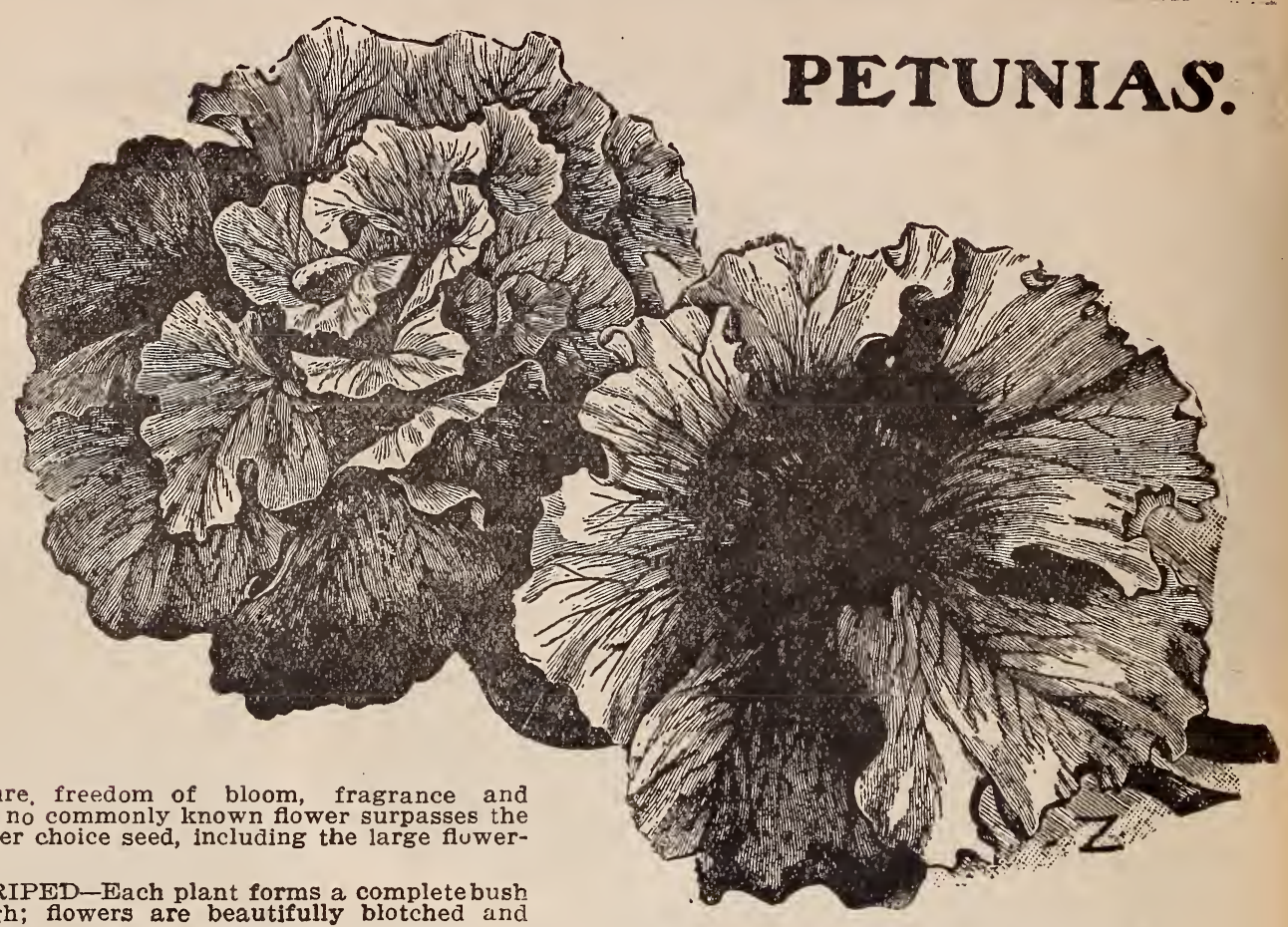

For easy culture, freedom of bloom, fragrance and variety of colors, no commonly known flower surpasses the Petunia. We offer choice seed, including the large fluwering varieties.

HYBRIDA STRIPED-Each plant forms a complete bush 5 to 10 inches high; flowers are beautifully blotched and striped. Pkt. 5 cts.

MIXED SORTS-All the best large flowering, fringed, double Petunias.Pkt. $5 \mathrm{cts}$.

\section{SALVIA (Scarlet Sagie.)}

SPLENDENS-This is a most gorgeou plent, For months, the great spikes of flaming scarlet almost cover the foliage. single plants sometimes carry 200 spikes: each spike being 10 to 12 inches in length. Pkt 5c,

\section{IENIIWORTH IVY.}

This is one of the most beautiful basket or vase plants; it is as easily grown from seed as Morning Glories. Plantscome in to bloom in a few weeks; has long drooping sprays of exquisite foliage, set with beautiful little flowers. It is a hardy perennial and likes shade and moisture. Pkt $5 c$.

\section{PRIMULA.}

(Chinese Primrose.)

FINE MIXED-A grand mixuure of all varieties and colors. Will give a succession of flowers throughout the season, and are noted for their beauty and fragrance. Thes are winter bloomers. Plit $5 \mathrm{c}$.

\section{SMILAX.}

One of the most desirable window vines ever grown. Its - legant and graceful foliage of rich glossy green has a most charming effect. P.kt 5 c.

\section{Read Our Flower Seed Offer on Pagie 45 Firteen Regiular Full Size Packets For Only 25c.}

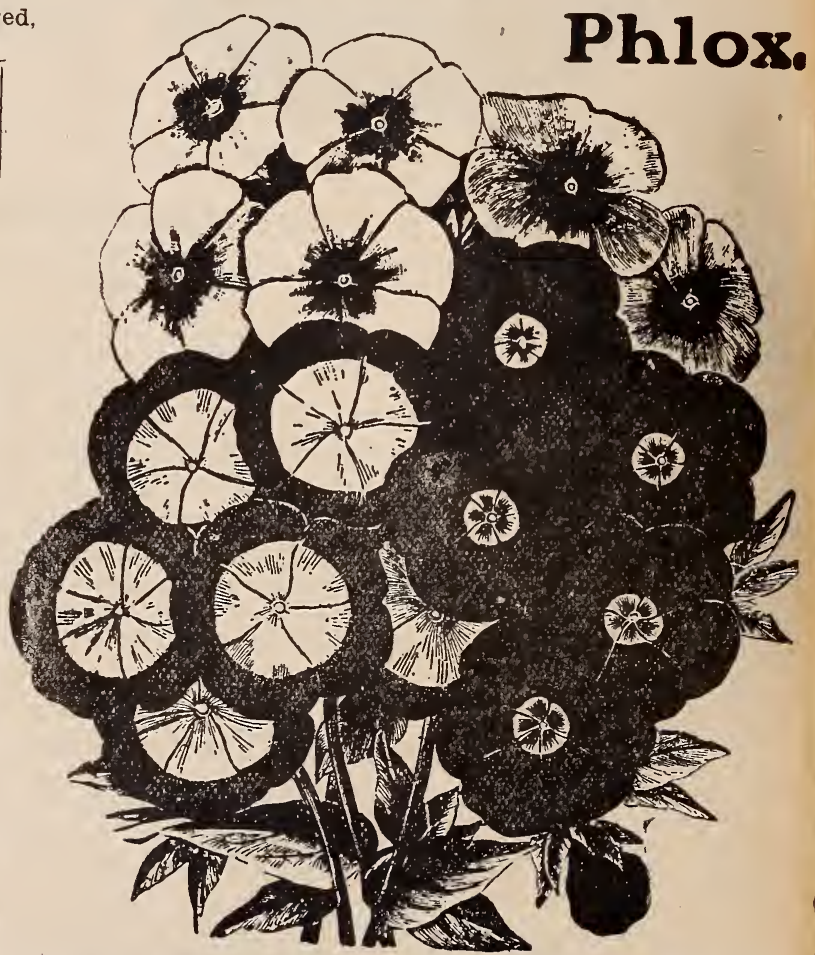

SPLENDENS - Pretty red flowers with white eyes: free flowering, early to bloom. You will see by the engraving that we have perfect beauties. Pkt $5 \mathrm{c}$.

ALBA GRANDIFLORA-These are magnificent, to say the least; flowers of unusual size and pure white. Pkt 5c. FINE MIXED-If you would like something that will con. tinue to delight you all through the summer try this fine mixture. contains the prettiest colors and finest 6orts. Plkt 50 . 


\section{SSELECT POPPIES.}

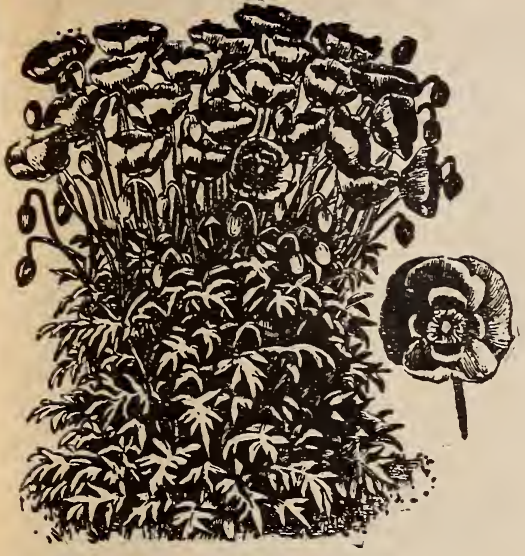

GOLDEN GATE POPRY. ily. Pkt. 5c. desirable. Pkt 5c. story. Pkt 5c. Pkt 5c.

\section{RICINUS. Castor Oil Bean.}

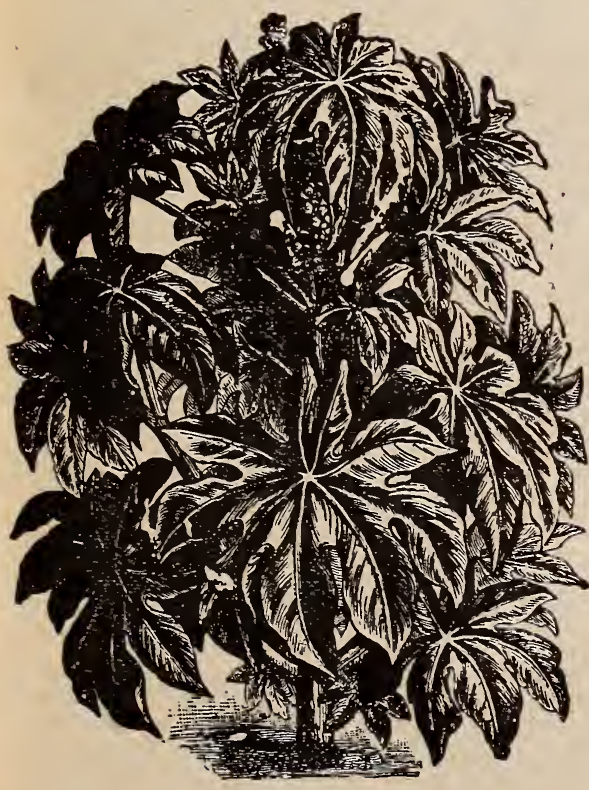

ZANZIBARENSIS-These semi-tropical plants are noted for their size and handsome foliage. Plants grow to a height of 14 feet. The large scalloped leaves, thickly set from top to bottom of bamboo-like stems, make them useful for shading purposes. Where there is a scarcity of shade plant these and you will be amply repaid. Pkt 5c.

\section{SENSITIVE PLANT}

This is a very odd plant, if you touch it with your finger tip it instantly wilts, but will soon revive. Bears small pink fow bu foliage is shaped s:milar to that of the Weather Plant. Pkt 5c.
SNOWDRIF"T - This grand novelty stands without a rival. Its pure white, very double appearance is worthy of admiration. Nothing more exquisite in the Poppy fam-

GOLDEN GATE These have blooms in a combination of colors all mottled, striped and blotched, making them very showy and

FINEST DOUBLEThe name tells the

MIXED-A combination of every good kind of Poppy; just the thing you will need for your flower garden.

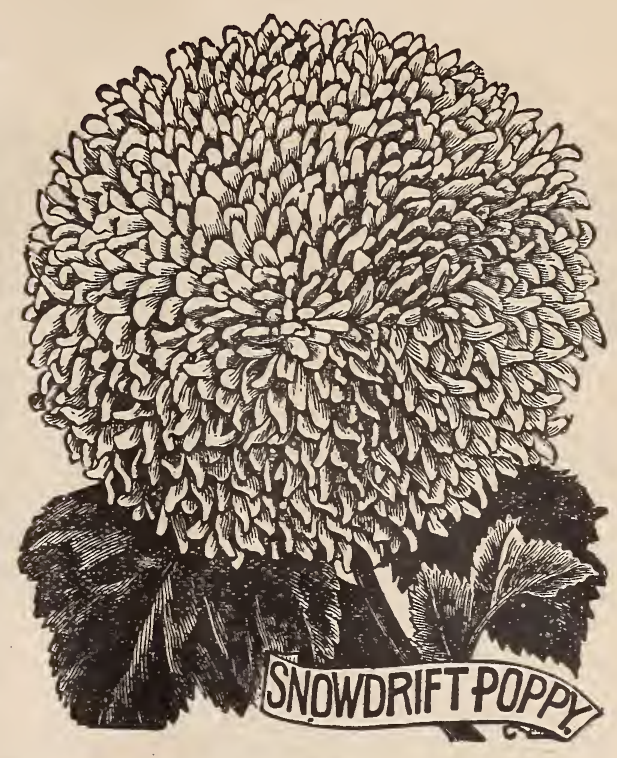

\section{PORTULACA.}

PORTULACA-This old flower has lost none of its popularity. It thrives under most any circumstances. Easily transplanted and gives profusion of bloom early and late in the season.

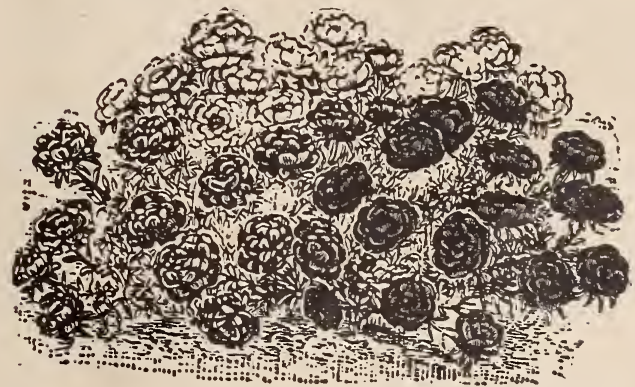

DOUBLE ROSE FLOWERED- $Y$ ou will see by our illustration how double these flowers are; we believe they resemble a miniature rose more than any other flower. Nothing prettier than these bright blossoms and waxy foliage for a flower garden. Pkt 5c.

FINEST SINGLE MIXED-Pk: $5 c$.

\section{STOCHS.}

LARGE FLOWERING GLOBE PYRAMIDAL-Has immense spikes of double flowers measuring from 2 to 3 inches in diameter: prized for their fragrance and beautiful colors. Excellent for boquets. This is the finest strain and all known colors mixeg. Pkt $10 \mathrm{c} ; 2$ for $15 \mathrm{c}$.

.TEN WEEKS-Mixed colors. The earliest variety. All colors. Pikt 5c.

\section{SUNFLOWERS.}

MANY FLOWERING DOUBLE-These grow very tall; flowers are double and one at every leaf joint, the top flower being largest. They produce great quantities of seed, which is very good for chickens. Pkt 5c.

MINIATURE-Very dwarf and bushy, with small leaves; flowers are very minute; plants greatly resemble dahlias. Good bloomers. Pkt 5c.

\section{SWEET WILLEAM.}

CHOICE MIXED-A hardy perennial, growing about 18 inches high colors and double and single mixed will be found here. P kt $5 \mathrm{c}$
All 


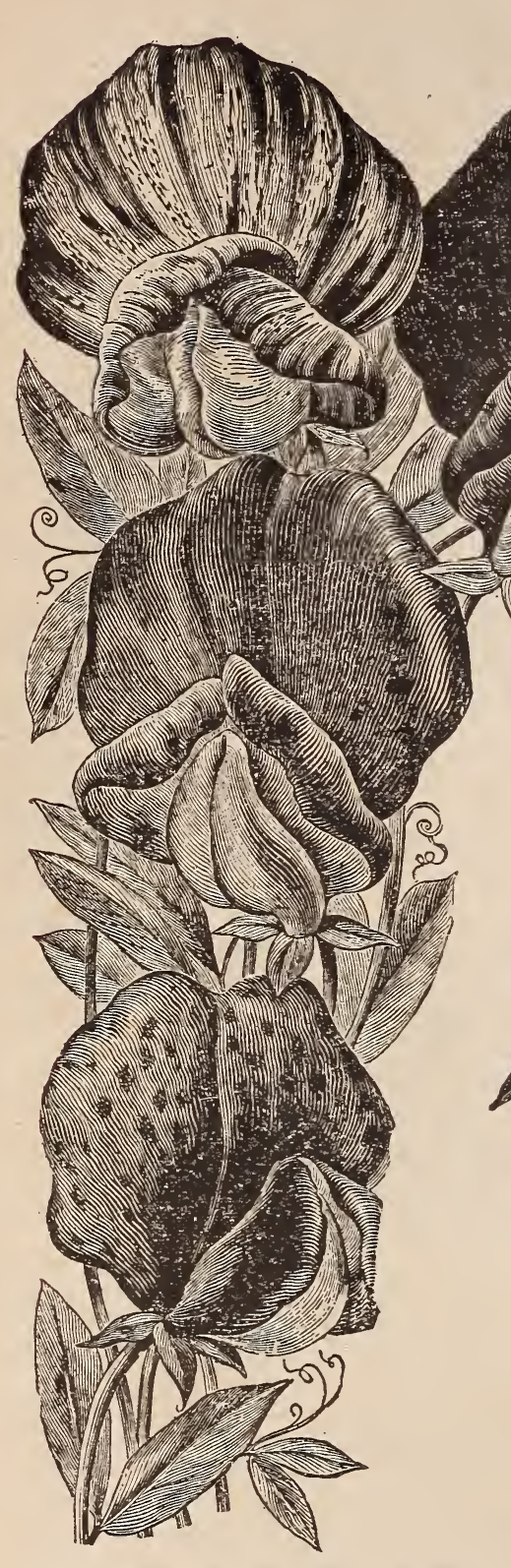

\section{Cupid Sweet Peas.}

r:UPID SWEET PEAS-These flourish : very dry seasons; because of their dense growth, they are not exposed to the drying influence of the air, as are the tall varieties. The flowers are equal in size to tall growers.

WHITE CUPID-These snowy white flowers are borne in threes on a stiff stem 6 inches high. Pkt. 5c.; oz. 10c.

PINK CUPID-Delicate rose tints; has same growth as white. Pkt 5c.; oz. 10c.

MIXED CUPID-Contains 12 or more variet:es of superior qualities. Pkt. 5c.; oz. $10 \mathrm{c}$.

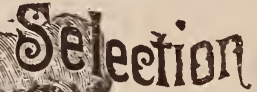
OF A.LL

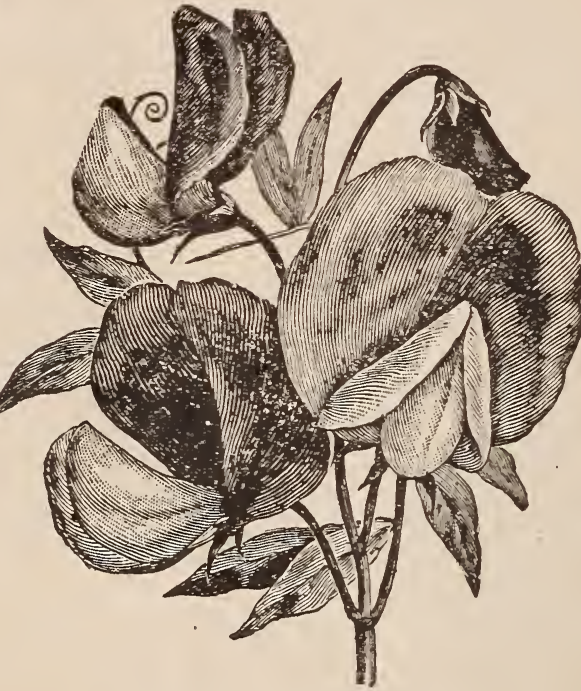

EARLIEST OF ALL SWEET PEAS.

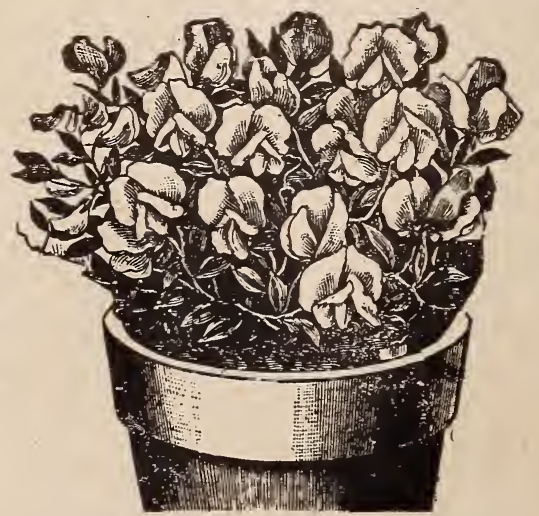

CUPID SWEETPEAS

\section{Zimmerman's} Select IMixture.

-These"are the Largest, Finest and Best $\mathrm{Sweet}$ Peas ever offered and our customers are enthusiastic over them, and hundreds of letters testify to their grand uer. This is most certainly A BARGAIN MIXTURE We say this with out hesitancy because it was prepared under our own supervision. We are offering you all the cholcest kinds at a very low price. Pkt 5c., oz 10c., $1 / 4 \mathrm{lb} 2 \mathrm{cc}$ $1 / 2$ lb $35 c$, postpaid

COUNTESS OF RADNOR -Delicate mauve and laven. der. Pkt 5c; oz 10c; 1/6 lb $15 c$.

D E L I G H T-White and crimson. Pkt 5c; oz 10c; $1 / 4$ lb $15 \mathrm{c}$.

DUCHESS OF EDIN. BURGH-Light red, wings several shades deeper. Same price as those quoted above.

EARLIEST OF ALLGrow from 18 to 24 inches in height and are fully ten days earlier than any other sort. They are rose color, with creamy wings, suffused with pale flesh tint, well filled. Pkt 5c: oz 10c; $1 / 4 \mathrm{lb} 15 \mathrm{c}$.

ELIZA ECKFORD-Flaked delicate rose, wings blush Same price as quoted above.

IMPERIAI, BLUE-Very oretty blue. Price same as quoted above.

STELLA MORSE - Pale straw color and rose. Pkt 5c: oz 10c: $1 / 4$ lb $15 \mathrm{c}$.

MONARCH-Deep purplish maroon. Same price as quoted above.

QUEEN VICTORIASomething new, deep cream variety. Pkt 5c; oz 10c; $1 / 4$ lb $15 \mathrm{c}$.

PRINCE EDWARD OF YORK-Exquisite tints of scarlet and rose. Same price as above quoted.

RAMONA-White and pink. Pkt 5c; oz 10c; $1 / 4$ le $15 \mathrm{c}$

BLANCH BURPEE-Very large snow white. Same price as above varieties.

BLANCH FERRY-Early varlety of special merit Same price as above quoted.

ECKFORD'S FINEST MIXED-This is Eckford's best, comprising all his most recent developments. He is known to have named and introduced more varieties than any other seedsman in the world. Pkt 5c; oz 10c; $1 / 4 \mathrm{lb} 15 \mathrm{c}$ 


\section{VERBENAS.}

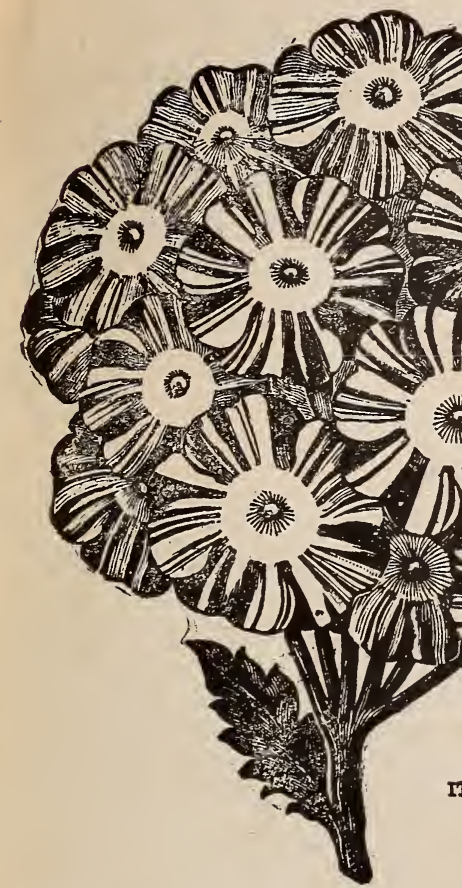

Verbenas are one of our best annuals and easier grown from seed than cuttings, as the plants are stronger and produce more bloom. Of low spreading growth.

NEW MAMMOTH-A strain conceded by all to be the finest; of vigorous growth and free flowering habit, embracing the most brilliant velvety colors.

ITALIAN STRIPED-Showy striped flowers of many colors. Pkt 5c.

HYBRIDA GOOD MIXED-This seed came from a collection of many bright and pleasing colors, also the Auricula-eyed type. All imported fresh seed. Pkt 5c.

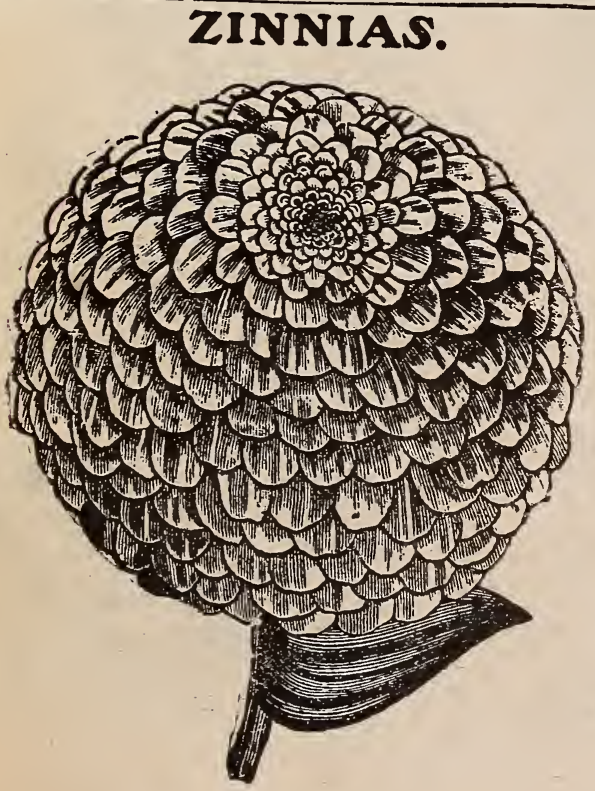

DOUBLE SWEET PEAS.

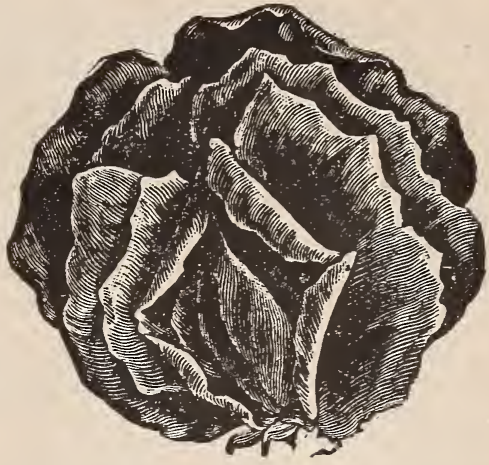

DOUBLE MIXTURE-These do not all come double, but usually 50 per cent will be. Sometimes they will all come double on one stem, while on others all single. This is a superfine mixture. Pkt. $5 \mathrm{c} ; \mathrm{oz}$. $10 \mathrm{c}$.

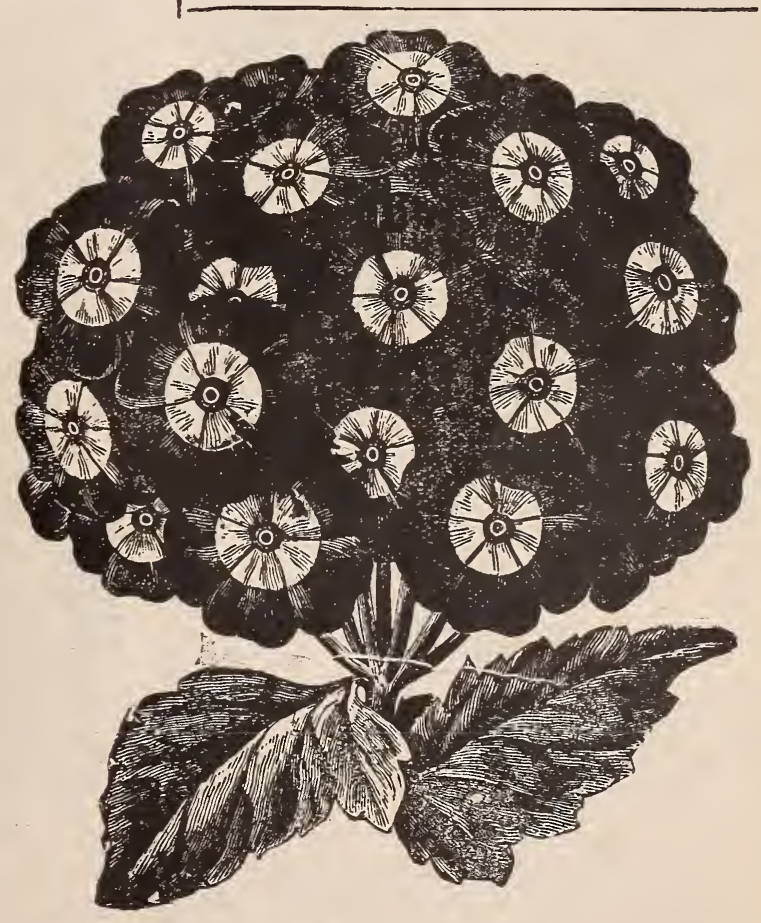

NEW MAMMOTH VERBENA.

Those not familiar with the perfection the Zinnia has attained may pass them by. Don't make a mistake.

GIANT MOMMOTH MIXED-This is a mixture of the largest Zinnias. Something entirely new; very double and show rare shades not found in former collections. Flowers striped and marked in scarlet, gold and white. Pkt. $5 \mathrm{c}$.

POMPONE MIXED-Cone shaped flowers, ranging from pink to scarlet and from pure white to cream and buff. Pkt. $5 \mathrm{c}$.

DOUBLE LILLIPUT MTXED-These form bushes 15 inches high and are covered with tiny double flowers about the stze of a dalsy. Bloom all summer and fall. Choice colors. Plat. $8 \mathrm{cr}$. 2 for $15 \mathrm{c}$. 


\section{GERANIUMS}

Price, $12 \mathrm{c}$ each; 3 for $30 \mathrm{c}$.

"A. H. TREGO."-Flowers semi-double and of extra-ordinary size for a Geranium; a rich dazzling scarlet; rich foliage and strong growth; without question the finest scarlet Geranium on the market.

BEAUTE POITEVINE.-Salmon color, good for bed ding.

COUNTESS OF HARCOURT.-Pure white, a free bloomer.

JEAN VIAUD.-Flowers semi-double, rose pink with white eye; good in every respect.

S. A. NUTT.-The best dark crimson bedder, also finelpot plant. 12c each; 3 for $30 \mathrm{c}$ postpaid.

1 plant each of the 4 double and 4 single for $75 \mathrm{c}$ post-paid.

CLYDE.-Pure soft even scarlet; grand for both bed ding and pot.

GRANVILLE.-Nice long stemmed pink, good for both beds and pots.

L'AUBE.- One of the finest single white Geraniums ogrown.

MRS. E. G. HILL. A most distince and pleasing shade of salmon. Free bloomer.

ROSE SCENTED GERANIUM.-Grown for the fra grance of its foliage; rich deep pink.

IVY LEAVED GERANIUM.-Pink, fine for baskets, pot plant and winter bloomer.

\section{SOME FINE BULBS.}

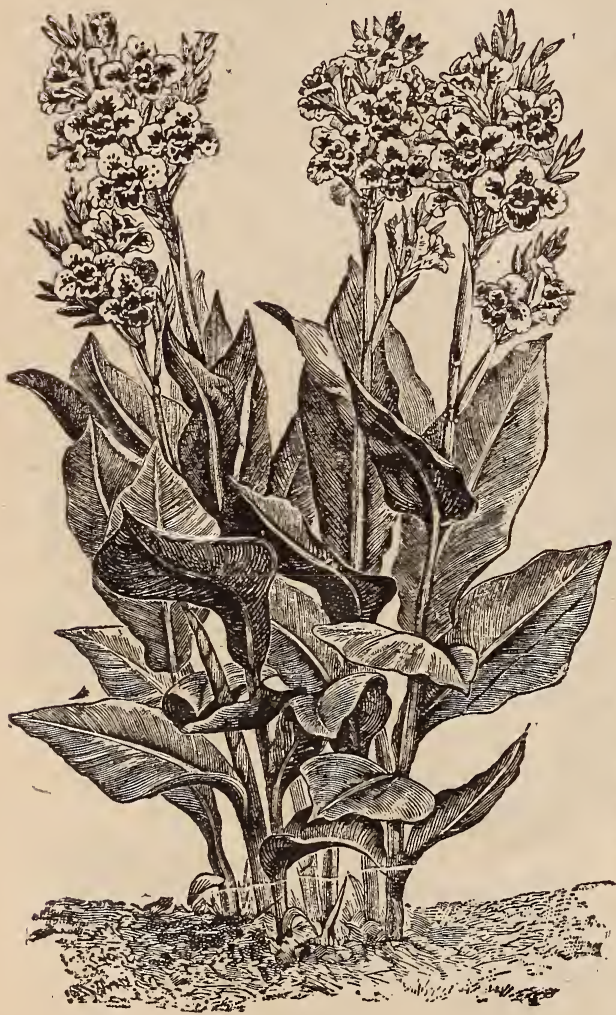

CANNAS

\section{CANNAS.}

The following comprise a list of best cannas. We give height of each:

ADMIRAL AVELLAN-Scarlet, overlaid with salmon, $5 \mathrm{ft}$. ALI.EMANIA-Salmon and yellow, 6 to $7 \mathrm{ft}$.

AUSTRIA-Pure canary yellow, 6 to $7 \mathrm{ft}$.

BEAUTE POITEVINE-Crimson, $3 \mathrm{ft}$.

BURBANK-Canary, lower petals spotted crimson, 6 to $7 \mathrm{ft}$.

CAPT. DRUJON-Red, dotted with yellow, 5 to $6 \mathrm{ft}$

CHAS. HENDERSON-Rich crimson, yellow throat, $3 \mathrm{ft}$

DUKE OF MARLBOROUGH-Dark Maroon. $3 \frac{1}{2} \mathrm{ft}$.

FLORENCE VAUGHAN-Yellow, dotted with scarlet, $4 \mathrm{ft}$.

MADAM CROZY-Crimson, bordered with yellow, $3 \frac{1}{2} \mathrm{ft}$.

MADAM CRAZY-Crimson, bordered with yellow, $3 \frac{1}{2} \mathrm{ft}$.

PHILADELPHIA-Large flowered, scarlet, $3 \mathrm{ft}$.

QUEEN CHARLOTTE-Orange red, edged with light yellow, $31 / 2 \mathrm{ft}$

ROSE UNIQUE-Rosy pink, $5 \mathrm{ft}$.

Price, dormant roots, $15 \mathrm{c}$ each; 3 for $40 \mathrm{c}$; 12 for $\$ 1.50$, postpaid.

\section{BEGONIAS}

TUBEROUS ROOTED-These are choice for pot culture or bedding. They are of low compact growth: waxy green leaves form a boautiful background for the flowers, which range from ivory-white low. Fcarlet through tints of rose, crimson, orange and bronze yeellow. For

SINGLE MIXED-Good, strong tubers, each 10cts.: 3 for 25 cts. 12 for $80 \mathrm{cts}$

DOUBLE MIXED-Each, 12 cts.; 12 for $\$ 1.00$.

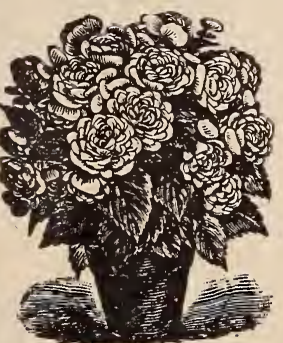

BEGONIA.
GLADIOLUS.

AUGUSTA.-Fine white with small violet stripes in throat; blue anthers.

INNOCENCE.-Pure white; flowers not large but very compact on

the stem.

1900.- Fine rich red with white spots on lower petals; long spikes, often three to four feet, with bloom extending fully a foot along the stem; covers a long blooming-season.

SHAKESPEARE.-Pure white splashed with pink and purple.

ISAAC BUCHANAN.-Clear bright yellow flowers borne on long

spikes. A striking and attractive variety; strong grower.

MARIE LEMOINE.-Pale creamy color flushed salmon-lilac.

Each, by mail, postpaid, 10c; $75 \mathrm{c}$ per dozen.

MIXED.-All colors, per dozen 50c, postpaid; $\$ 3.00$ per 100 by express at purchaser's expense.

The prices are for the strongest and best bulbs; smaller bulbs can be supplied at lower prices, but they will produce blooms of inferior size and quality, if at all, the first year.

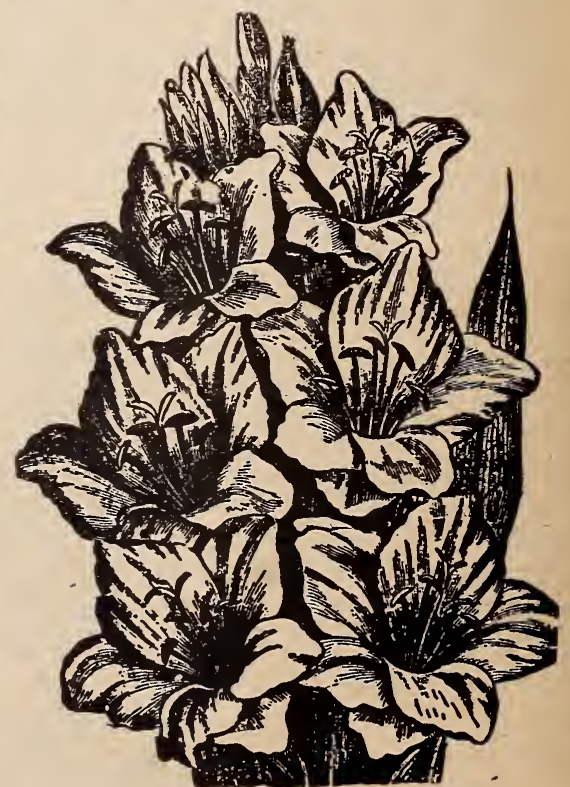

GLADIOLUS 


\section{DAHLIAS.}

Dahlias are great favorites for autumn fiowering. Because of their la rge and varied range of colors. they are always popular. Our mixed contains all the best. $15 \mathrm{c}$. each. 6 for $80 \mathrm{c}, 12$ for $\$ 1,50$ postpaid

\section{PAEONIES.}

nnce planted will last a lifetime. Produce most magniflcent flowers in great profusion. Pink or crimson, 25, each, 6 for $\$ 1.25$ Pure v-hite, $30 \mathrm{c}$ each, 6 for $\$ 1.5$, all postpaid.

\section{We pay Postage on Bulbs}

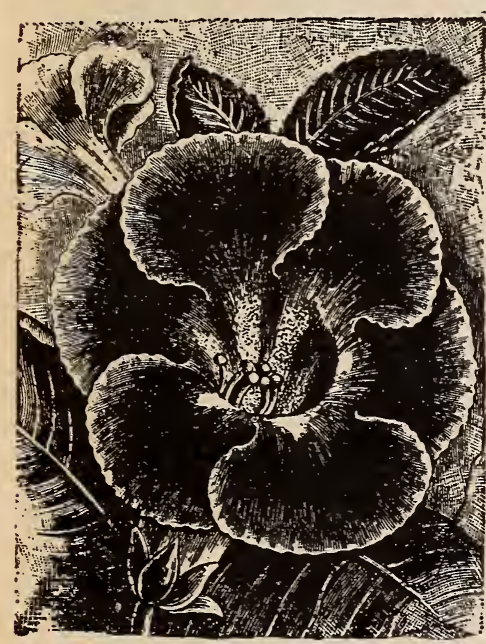

OXALIS.

Very handsome dark green clover-like foliage. Dainty little flowers, something the shape of forget-me-nots, add their share of beauty to this charming plant. Pretty to use in baskets.

WHITE, PINK. RED-Price of each separate color or mixture of three colors same price 4 for $5 \mathrm{cts}$; 12 for $10 \mathrm{cis}$ : 25 for 15 cts.: 50 for 40 cts. postpaid.

\section{CALADIUM.}

Elephant Ears-Is mostiefe stive for single plant on the lawn or massed in large beds. has light green leaves, often 3 feet by 20 inches Bulbs can be stored in a dry place and kept through the winter. Fine large bulbs $12 \mathrm{c}$ each 3 for $30 \mathrm{c}$ postpaid.

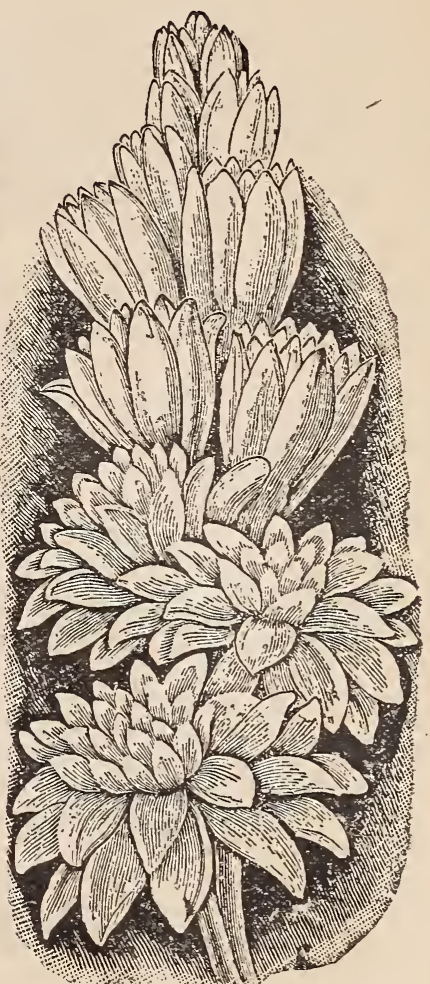

TUBEROSE

EXCELSIOR PEARL-We handle nothing but the highest type of tuberose, hence we list this well known varlety. It's of dwart habit, rery double. Succeeds best in a warm, sunny place. Flowers are a pure waxy white and very sweet scented. Grow about 18 inches high and stems bear a dozen or more flowers. Price $5 \mathrm{cts}$. each; 3 for $10 \mathrm{cts}, 12$ for $40 \mathrm{cts}$.

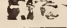

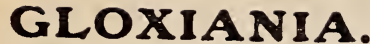

These are beautiful beyond description. The rich and many colored cup-shaped flowers, mounted on stiff stems, make a grand show against a background of velvety leaves. They flower quickly after planting. Why not start some for Easter decoration? We offer the choicest mixed. In them you'll find all the handsome kinds. 12c each; 3 for $30 \mathrm{c}$; 12 for 1.00 postpaid.

\section{CLIMBERS.}

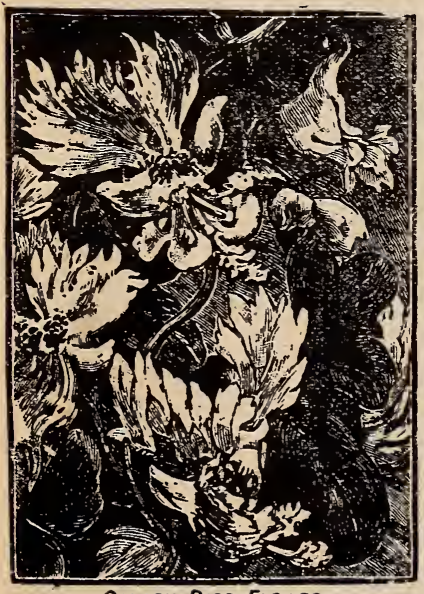

Canari Biad flower.
JAPANESE MIXED-This is entirely different from the common Morning Glory. They are of gigantic size, measuring from 4 to 6 inches across. They contain every color, and blending of colors, in the rainbow. They are st riped, blotched, mottled, often having from 10 to 12 colors in a single flower. Leaves are very large, d ark green and variegated. These are certainly very $f$ ine climbers. Pkt 5c.

CYPRESS VINE--.Has the finest dark green $f$ liage of any the garden vines. It is lovely for ornamenting unsightly trunks of old trees and fences. It makes a lovely trellis. Pkt 5c., postpald.

CANARY BIRD---Beautiful delicate vine, with handsome foliage and bears an abundance of canary-colored llowers. Pkt 5c, postpaid.

WISTARIA-Called Hyacinth Bean. etc. One of the prettiest climbers and the vines are covered with beautiful flowers. Pkt 5c., postpaid.

COBA VINE---Very rapid annual climber, running up 20 to 30 feet in a season. Has bell-shaped flowers of purplishlilac color. Pkt,5c, postpaid.

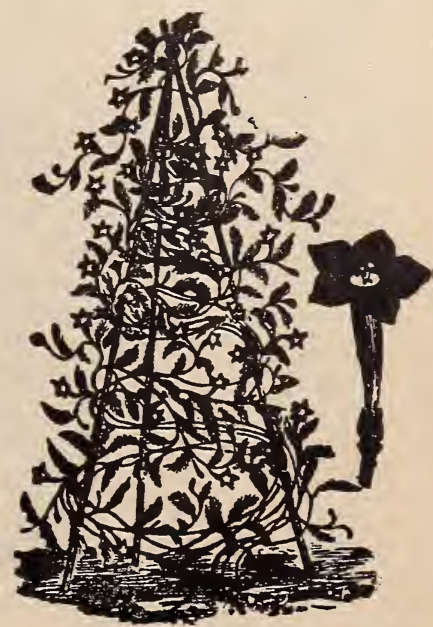

CYPRESS VINE. 


\section{Roses and Plants.}

Orders for Roses and Plants will be filled separately from seed or other orders and will be shipped as soon as the weather will permit.

We make a specialty of fine Roses, sending out only good strong plants, in all instances as large as can be advantageously sent by mall.

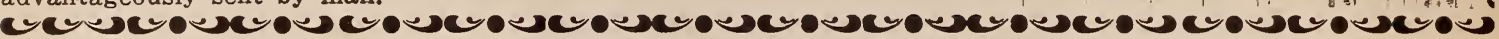

\section{EVER-BLOOMING BEDDING ROSES. Teas and Hybrid Teas.}

GRUSS AU TEPLITZ.-This is a Rose for everybody, especially for those who have no greenhouse and depend on the garden for flowers. It does well under the most ordinary condition. The color is a rich scarlet, foliage beautiful. See price on front page of cover. Be sure to include it in your order.

Any of the following: 10c each; 6 for 50c; 12 for $\$ 1,00$, postpaid.

AGGRIPINA.-Deep crimson, an old garden favorite.

AUGUSTINE GUINNOISEAU (White La France).-Do you know La France? If so, you know this beautiful new Rose. The color is a pearly white, sometimes tinted with fawn.

BURBANK.-This Rose was originated by Mr. Luther Burbank, and out of 75,000 crossbred seedlings this was the one he selected to bear his name. It is a cherry crimson, peculiarly adapted for both bedding and house culture in winter.

THE BRIDE.-This old favorite needs little comment. It is a pure white Tea Rose, strong healthy grower, does equally as well for house culture as in open ground.

BRIDESMAID.-A Tea Rose; clear dark pink, very fine.

BON SILENE.-Of all the Tea Roses there is none better. It is a deep pink, noted for the immense size and beauty of its buds.

CATHERINE MERMET.-A handsome pink Tea Rose for summer and winter bloom.

CAROLINE MARINESSE.-Very hardy, always in flower even in very dry weather. It is pure white, pink tinted, of low growing habit, making it nice for borders.

CHAMPION OF THE WORLD.-A lovely clear deep pink. Flowers large size.

CLOTHILDE SOUPERT.-In this Rose we find all the good qualities combined. It is white, shading to deep pink toward the center.

DUCHESS OF ALBANY.-This Rose is much like La France, except its color is more brilliant, it being a very gorgeous red.

ETOILE DE LYON.-A beautiful pure yellow free blooming Rose. If something satisfactory is desired, order this one.

HERMOSA.-An excellent clear rose color, blooms in clusters.

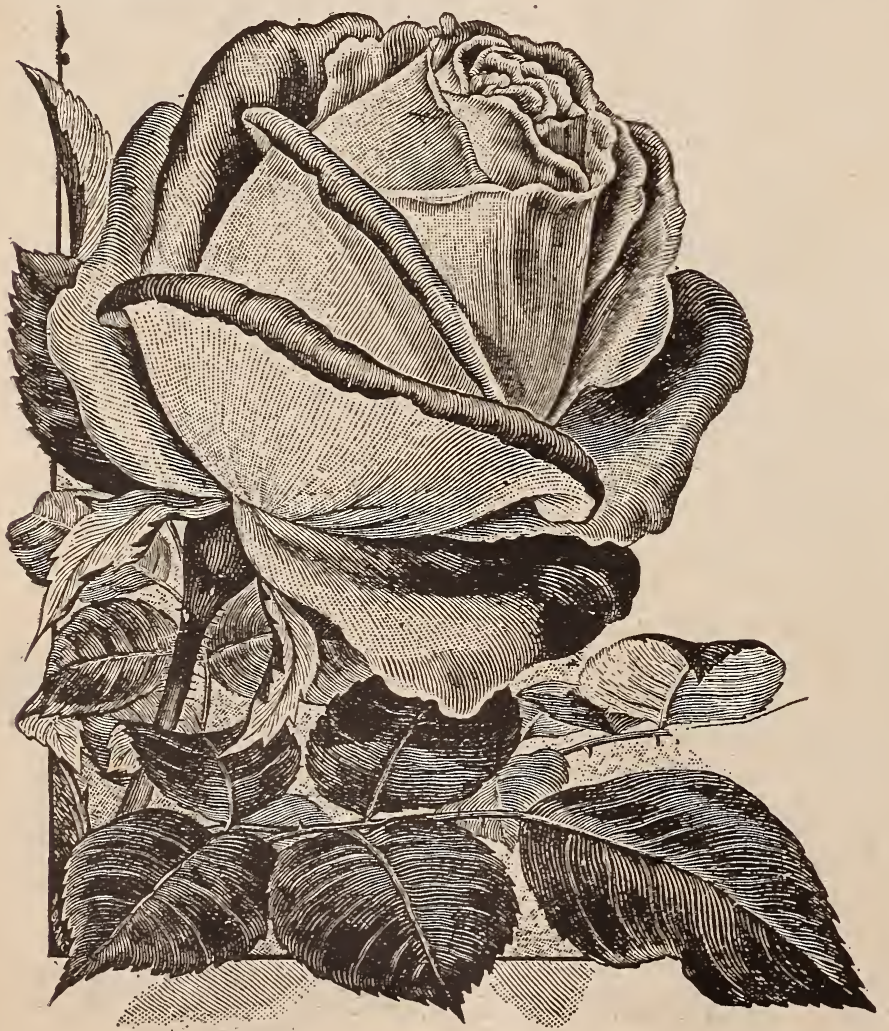

ANNE DE DIESBACH.-Color brilliant carmine; long pointed buds, large flowers, full and double and fragrant. One of the really good Roses.

ALFRED COLOMB.-Extra large, double fragrant cherry red flowers.

BARON DE BONSTETTIN.-A large, full, double velvety maroon Rose, sometimes almost purple.

KAISERIN AUGUSTA VICTORIA. -In this pure white Rose is combined all the good qualities, rich perfume, vigorous growth and everything essential to the production of a perfect Rose.

LA FRANCE.-The old garden favorite, the queen of all Roses. No variety surpasses its silvery rose coloring.

MADAME ANGELIQUE VLYSSET.-This is a striped La France, the markings are plain, the variegation a rose on a stain background.

MRS. DE GRAW.-In color, rich glossy pink; very fragrant, vigorous grower, every shoot loaded with flowers.

MOSELLA (Yellow Soupert).-Flowers very double, white on beautiful light yellow background, which becomes a chrome yellow in ground, whic

MARION DINGEE.-This Rose is excellent a deep crimson borne on long stems, making a graceful bush with its large deep green leaves.

MARIE GUILLOT.-We recommend this as one of the most satisfactory white Tea Roses in cultivation. The flowers are large, full and double.

MADAM HOSTE-A Rose of large size, fine form. In cool weather it is ivory white, in summer a bright canary with a deep amber center.

METEOR.-The color of this Rose is a rich velvety crimson, very striking, modérately hardy. 
TEAS and HYBRID TEAS-Conitnued.

NIPHETOS.-A very fine white rose; buas are 3 inches long.

PERLE DES JARDINS.-A clear golden yellow Rose; very desirable from every standpoint.

PRINCESS BONNIE.-A richer crimson was never seen in a Rose, while its fragrance is even more delicate than the La France.

PINK SOUPERT.-Identical with Clothilde Soupert, except in color of flower. It blos soms early and profuse ly. The color is adark shining pink.

SUNSET.-This Rose is lovely. A rich golden amber, shaded with dark red, a very good likeness of a summer sunset; flowers large, finely perfumed; free bloomer.

SOUVENIR DE LA MALMAISON.-This fine flesh-colored Rose is a fine bloomer and stands dry weather nicely.

SAFRANO.-A bright apricot yellow, changing to orange and fawn, sometimes tinted with pink; fine in every respect. SOUVENIR DE PRESIDENT CARNOT.-The color is a new delicate rosy blush, shaded a trifle deeper near
the center; long pointed buds. Excellent.

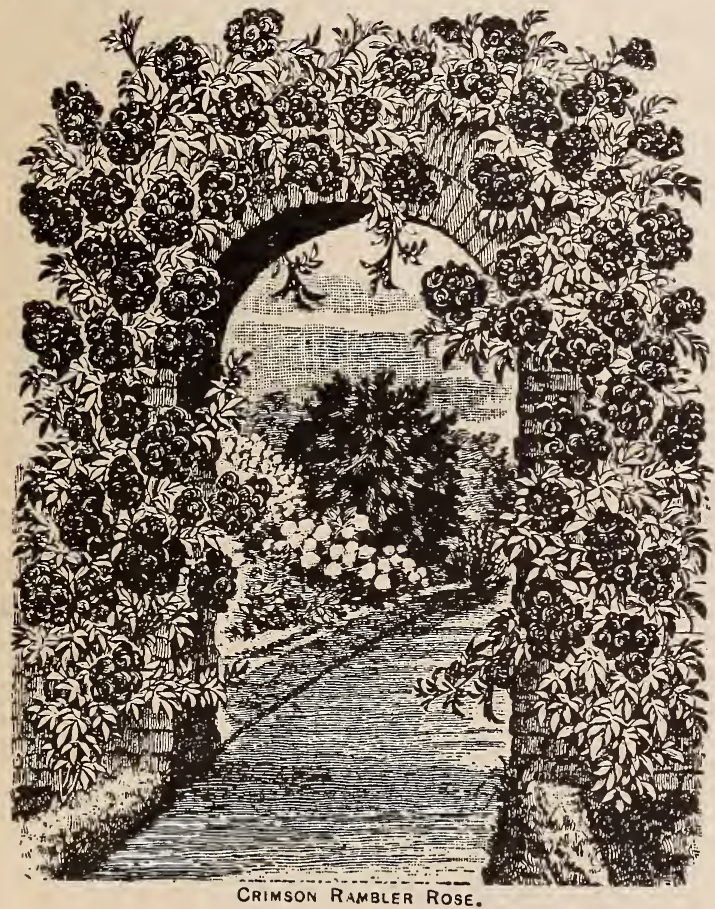

\section{Hardy Climbing Roses.}

BABY RAMBLER.-The ever-blooming Dwarf Crimson Rambler, in bloom continuously.

This rose begins to bloom when very small, forming clusters of flowers as large as the Crimson Rambler. It is a brilliant red, of bushy habit, compact growth, forming plants $11 / 2 \mathrm{ft}$. ligh in a 6 in pot. This rose bids fair summer. 20c each; 2 for $35 \mathrm{c}$

The following varieties are valued for training over arbors, trellises and verandas, etc. Price, $12 \mathrm{c}$ each; 3 for $30 \mathrm{c}$, postpaid.

They will bloom the second year and are hardy.

BALTIMORE BELLE.-Pale blush, becoming nearly white, very double.

EMPRESS OF CHINA.-Color, shell pink; hardy, a strong grower.

GREVILLE OR SEVEN SISTERS.-Flowers in large clusters, varies in color from white to crimson.

MARY WASHINGTON.-The flowers are pure white and very double. Very prolific and good grower.

QUEEN OF THE PRAIRIES.-A clear, bright pink, one of the best.

RUSSELL'S COTTAGE.-A dark velvety crimson, double and profuse bloomer.

TENNESSEE BELLE.-A rosy blush, vigorous climber, free bloomer.

HELENE.-A seedling of the Crimson Rambler, color soft rose, almost blush, base of petal yellowish white, buds borne in clusters of 20 to 50 .

PHILADELPHIA.-A pure deep rich crimson, holding its color as long as the flowers last, needs no protection.

CRIMSON RAMBLER.-This is a splendid Rose, and another year's trial proves that it is perfectly hardy, making shoots 10 to 12 feet in a season. Produces 25 to 30 flowers in cluster, entirely covering the plant from the ground to the top with a mass of bright, glowing crimson. It has been very largely advertised and is very popular.

THE WHITE RAMBLER.-Pure white, small, double flowers. It is a fitting companion for the Pink Rambler, closely resembling it in foliage as well as in the great cluster of pure white flowers.

THE YELLOW RAMBLER.-This is the only hardy Yellow Climbing Rose, and has been found to successfully withstand, without protection, antinued temperature of from zero to 2 degrees below, which proves it to be far hardier than any other Yellow Climbing Rose yet introduced and can be easily grown where other Roses fail As many as 150 blossoms grow in a cluster; buds a bright yellow, changing to a beautiful creamy tinge.

\section{Hybrid Perpetual Roses.}

Roses of this class produce the largest flowers and are the hardiest of any class; they are especially adapted to outdoor cultivation. Some do not bloom until the second season, but when established they bloom freely in June and July, and at intervals throughout the summer and fall. They should be pruned each spring. $12 \mathrm{c}$ each; 3 for $35 \mathrm{c}$; 6 for $60 \mathrm{c}$ postpaid.

CAPRICE.-A striped Rose. The ground color is a satiny pink, distinctly striped and dashed with white and carmine.

CAROLINE DE SANSEL.-Clear, brilliant rose color shading to rosy lilac.

CHARLES LEFEBVRE.-Very velvety redish crimson, sometimes with a tint of purple.

CLIO.-This is one of the finest of Roses. A vigorous grower, hardy free flowering. Color a delicate flesh.

DUC DE ROHAN.-Vermillion. An old and valuable variety.

FISHER HOLMES.-Rich crimson, very double.

GEN. JACQUEMINOT.-An old favorite everyone knows at least by name and reputation. A rich crimson scarlet.

GEN. WASHINGTON.-Soft glossy scarlet, double and blooms in the fall when roses are scarce.

HELEN KELLER.-The color is a brilliant cerise, flowers large; full, fragrant, blooms early and late. 


\section{HYBRID PERPETUALS, Continued.}

JULES MARGOTTIN.-Bright carmine; splendid Rose.

JOHN KEYNES. - rine deep reddish-maroon, hardy and free from disease.

LA REINE.-Clear bright Rose; large and double.

MME. CHAS. WOOD.- Bright firey scarlet, passing to rosy crimson shaded with maroon; one of the best.

MARSHALL P. WILDER.-Bright crimson, full, large flowers; very good.

MAURICE BERNARDIN.-Full, large vermilion flowers; excellent.

MRS. CLEVELAND. - Waxy; flesh pink, large, good shape, free bloomer.

MME. GEORGES BRUANT.-This Rose blooms in clusters of five; fragrant, a pure white.

MARCHIONESS OF LORN.-Handsome rose color shaded with carmine. Truly an ever bloomer.

MARGARET DICKSON. - This is a beauty; white, having the luster of a pearl.

MRS. R. G. SHARMAN CHAWFORD.-Color deep rosy pink, the outer petals tinted with pale flesh in a new and unique shade, white at the base of petals.

MME. GABRIEL LUIZET.-An exquisite shade of rose, suffused with lavender and pearl. Often mistaken for a La France.

MAGNACHARTA.-Clear rosy red; one of the best.

MRS. JOHN LAING.-An exquisitely shaded pink, borne on long stiff stems.

PRIDE OF WALTHAM.-Flesh color, shaded with bright rose; very fine.

PRINCE CAMILLE DE ROHAN.-Flowers are very large, color deep rich crimson passing to intense maroon,
. At a distance they really appear black.

ULRICH BRUNNER.-The thornless Rose. Flowers of fine form, color a cherry red.

VICTOR VERDIER.-Rose color with carmine center; make a strong bush with few thorns.

15c each; 3 (one of each) for $40 \mathrm{c}$.

\section{MOSS ROSES.}

BLANCHE MOREAU.-This Rose is produced in clusters and are large, full and pure white with an abundance of deep green moss.

CRIMSON GLOBE.-A fine deep crimson, buds well mossed.

PRINCESS ADELAIDE.-One of the best. A- bright rosy pink.

\section{Door Yard Collection.}

For $\$ 1.50$ we will send postpaid our Everblooming Door Yard Collection, consisting of seventeen of the hardiest and best varieties of Roses, no two alike. You cannot make an investment of so small a sum and bring such returns in pleasure as this. A bed or hedge of Roses is something every customer of ours should have at this low price.

The following are the names of varieties; description can be found in the descriptive list of Roses:

Aggripina, Burbank, Clothilde Soupert, Champion of the World, Caroline Marniesse, Duchess of Albany, Etolle De Lyon, Hermosa, La France, Mrs. Degraw, Madame Hoste, Marion Dingee, Mosella (Yellow Soupert), Pink Soupert, Princess Bonnie Safrano, Souvenir De La Malmaison.

\section{Memorial Collection.}

Three hardy White Roses for cemetery planting.

Price 28 c postpaid.

COQUETTE DES ALPS.-Pure white, tinged with pink in the center; flowers are good size; a continuous bloomer.

COQUETTE DES BLANCHES.-Similar to the one above except the center is cream instead of pink.

MME. PLANTIER.-This fine variety is as ornamental as a Hydrangea. Flowers are pure white and double. It is especially good for cemetery planting for three reasons, . namely, hardiness, needs little pruning, very prolific.

\section{Happy Home Collection.} Six red, six pink, three white, one striped; postpaid for only $\$ 1.50$ Sixteen handsome hardy Hybrid Perpetual
Roses as named below. For description see preceding pages:
Alfred Colcomb,
Anne De Diesbach,
Baron Bonstettin,
Caprice,
Coquette Des Alps,
Coquette Des Blanches,
Gen. Jacqueminot,
Gen. Washington,

John Hopper,

Madame Gabriel Luizet,

Madame Plantier

Magna Charta,

Mrs. John Laing,

Paul Neyron

Prince Camille De Rohan,

\section{HARDY FLOWERING SHRUBS.}

SHRUB ORDERS SHOULD REACH US NOT LATER THAN APRIL 15, AS THE PLANTS WILL COMMENCE GROWING SOON AFTER THAT DATE.

ALTHEA (Rose of Sharon).-They are covered with rose-like flowers during August and September, when other flowers are scarce. We have three colors, red, purple, and white, all double. Price 12c each; 1 of each
color for $30 \mathrm{c}$ postpaid.

DENTZIAS.-We have three varieties, namely:

Crenata; height 4 to $6 \mathrm{ft}$, white flowers tinged on the outside with pink; blooms in June.

Gracilis; dwarf, 2 to 3 ft. high; flowers white; hardy; for the garden or splendid for pot sulture and winter blooming.

Pride of Rochester; double white.

Price $12 \mathrm{c}$ each; 3 for $30 \mathrm{c}$ postpaid.

FORSYTHIA FORTUNEII.-The first shrub to bloom in the spring. Bright yellow flowers, green leaves. Price 12c each; 3 for $30 \mathrm{c}$ postpaid.

BUSH HONEYSUCKLE.-Red and White Tartarian. Price 12c each or 2 for 20c postpaid.

HYDRANGEA PANICULATA GRANDIFLORA (The Hardy Hydrangea).-Every branch is crowned with an immense panicle of fleecy white flowers changing to a pink hue from August to last of October. This is one of
the handsomest shrubs in cultivation. Price $10 \mathrm{c}$ each postpaid.

HYDRANGEA OTASKA.-A Japanese variety, produces immense heads of pink flowers. A little shade and plenty of water meet all their demands. Set them away in the cellar to rest in the winter. Buy one for your
veranda. HYDRANGEA THOS. HOGG.-Large white; may be grown for lawn or pot plant on the veranda. Price 18c
each; 3 for 50c postpald.

SNOWBALL (Ordinary).-Price each 12c; 3 for 3ue postpaid. SNOWBALL (Japanese).-Exceedingly choice, both in foliage and white blossom. Difficult to propagate, hence
its higher price. Each 15c; 3 for $40 \mathrm{c}$ postpaid. 
SPIREA (Meadow Sweet).-This class of shrub will amply repay one with an abundance of flowers; easy cul-

tivation, rapid growth, etc.
SPIREA PRUNIFOLIA (Bridal Wreath).-Double white, blossoming profusely the length of the branches.
SPIR

round, loaded with white bloom in May or June.

SPIREA BUMALDA.-A dwarf variety, rose colored flowers, bears all summer.

SPIREA CALLOSA ALBA.-Dwarf white; bears in July and August.

Price 12c each: 5 or more at $10 \mathrm{c}$ each postpaid.

Price 12c each; 5 or more at 10c each postpaid. $20 \mathrm{c}$ postpaid.

SYRINGA (Mock Orange).-Price 12c each; 2 for $20 \mathrm{c}$ postp

GOLDEN.-The beauty of this variety is its yellow leaves, makes a fine contrast in with other shrubs.

HARDY PERENNIAL PHLOX.

Among hardy plants none are more easily grown than these. They succeed well in ordinary soil, sending up

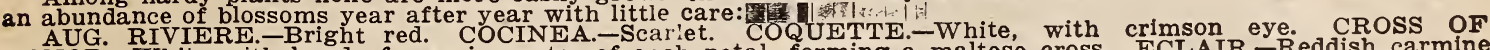
AUG. RThite with band of rose in center of each petal, forming a maltese cross. ECLAIR.-Reddish carmine HONOR.- White with band of rose in center of each petal, forming a maltese cross. with darker eye. EDGAR QUINET.-ROSY amarinth. ISABEY.-Orange salmon with crimson centimon rose, free flower-Soft, reddish pink, rose eye. M

Price of dormant roots, each $15 \mathrm{c} ; 6$ for $80 \mathrm{c} ; 12$ for $\$ 1.50$, postpaid.

RUBECKIA (Golden Glow).-Double. These are one of the handsomest ornamental plants for the garden, lawn or park. Easy to grow; sure to bloom great yellow flowers as fine as cultivated Chrysanthemums. Include this in your order and you will be pleased. Price $10 \mathrm{c}$ each; 3 for $25 \mathrm{c}$ postpaid.

YUCCA FILAMENTOSA (Adam's Needle).-It is a hardy evergreen. The stems rising 4 or 4 feet from the tuft of narrow leaves. Bears cream bell-shaped flowers. $15 \mathrm{c}$ each; 3 for $40 \mathrm{c}$ postpaid.

\section{HARDY CLIMBERS.}

CLEMATIS.-These ornamental hardy vines are especially for house fronts or may be used with fine effect

on fences, etc. We list the best varieties:

DUCHESS OF EDINGURGH.-Double White.

HENRYI.-Pure white.

JACKMANNI.-Flowers large, rich velvety purple, produced in masses.

MADAM BARON VEILI,ARD.-Quite like its parent, Jackmanni, but color light lavender.

MADAME EDOUARD ANDRE.-Nearest to red in the Clematis family.

PANICULATA.-Small flowers borne on long stems in clusters, in August.

RAMONA.-Large lavender-blue flowers, often nine inches across.

Price 14c each; 3 for $30 \mathrm{c}$; 1 each of the seven varieties for $80 \mathrm{c}$ postpaid.

CINNAMON VINE-Very rapid climber, and will grow for years. Strong tubers, 10c each, 3 for 20c., 12 for 50c., postpaid.

BOSTON IVY-One of the most popular vines. Hardy and clings to any smooth surface. 12c each, 3 for $30 \mathrm{c}$, postpaid.

BIGNONIA (Trumpet Creeper)-Grows fast and is very showy; flowers red with yellow throat. 12c each, 3 for $30 \mathrm{c}$ postpaid

\section{HONEYSUCKLES.}

CHINESE.-Reddish green foliage, red flower, buds when expanded show cream petals.

HALL'S JAPAN.-Pure white flowers changing to yellow. Bloom from July to November.

MONTHLY FRAGRANT,-All the name implies; red and yellow blossoms.

SCARLET TRIUMPH.-Red trumpet-shaped flowers.
Price 12c each; one of each variety for $40 \mathrm{c}$ postpaid.

ENGLISH IVY.-Hardy; foliage dark green and glossy. Good for covering walls and ground where grass will not grow. Price 12c each; 3 for $30 \mathrm{c}$ postpaid.

PASSION FLOWER.-A fine climber; flowers from 2 to 3 inches across; white with purple corona. Price 12c each; 3 for $30 \mathrm{c}$ postpaid.

WISTERIA.-Valuable where tall growing vines are desired. Flowers are long and in clusters.

CHINESE PURPLE. $-12 \mathrm{c}$ each; 3 for $30 \mathrm{c}$ postpaid.

CHINESE WHITE.-16c each; 3 for $45 \mathrm{c}$ postpaid; or one of each for $25 \mathrm{c}$ postpaid.

\section{FUCHSIAS.}

LITTLE BEAUTY (Single).-Bright red tube and sepals; corolla rich purple. Flowers $11 / 2$ in. long.

ROSALIND (Single).-Tube and sepals white; corolla Magenta pink.

GIGANTEA (Double) - The tube and sepals carmine; corolla light Magenta.

MRS. E. G. HILL.- Most perfect double white ever introauced. Tube and sepals red.

PHENOMENAL. - Sepals red, corolla violet.

STORM KING.-Sepals scarlet; corolla red and white.

$12 \mathrm{c}$ each; 3 for $30 \mathrm{c}$ postpaid.

DR. LIVINGSTON.-Fine dark blue clusters.

\section{HELIOTROPE.}

WHITE LADY.-Large pure white.
$12 \mathrm{c}$ each; the two for $20 \mathrm{c}$ postpaid.

Price 10c each; 6 for 50c postpaid.

\section{CARNATIONS.}

DAYBREAK.-Delicate salmon pink.

ELDORADO.-Light clear yellow, petals edged with a narrow band of pink.

FLORA HILL.-The largest white variety to date. H. H. G. H. CRANE.-The best large scarlet grown.

MRS. THOS. LAWSON.-No plant has ever received so much description and free advertising from newspapers of the whole country as this Carnation, which is said to have sold for $\$ 30,000$. It is very large and beautiful shade of pink.

ENCHANTRESS.-One of the recent introductions; an exquisitely delicate shade of shell pink; blooms early

and continuously.

DOROTHY WHITNEY.-Deep golden yellow.

LADY BOUNTIFUL.-Pure white, valuable for garden planting as well as under glass.

Price $10 \mathrm{c}$ each; 6 for $50 \mathrm{c}$.

\section{CHRYSANTHEMUMS.}

GEO. W. CHILDS.-Deep rich crimson, long stiff stems. Leaves grow close to the flower.

GLORY OF THE PACIFIC.-An early pink sort. Flowers are of immense size; plant has a dwarfish growth. GOLDEN WEDDING. - The grandest golden yellow Chrysanthemum ever offered.

IVORY.-Pure white; fine for pot culture.

MAUDE DEAN. Fne pink shell shaped variety.

MME. F. BERGMANN.-Large, full white, cream center.

BLACK HAWK.-Dark crimson; largest and best of its color.

COL. D. APPLETON.-Deep golden yellow; perfect in shape and color as wel as in foliage and habit of growth.

TIMOTHY EATON.-Pure white blooms of immense size and of globular shape. 


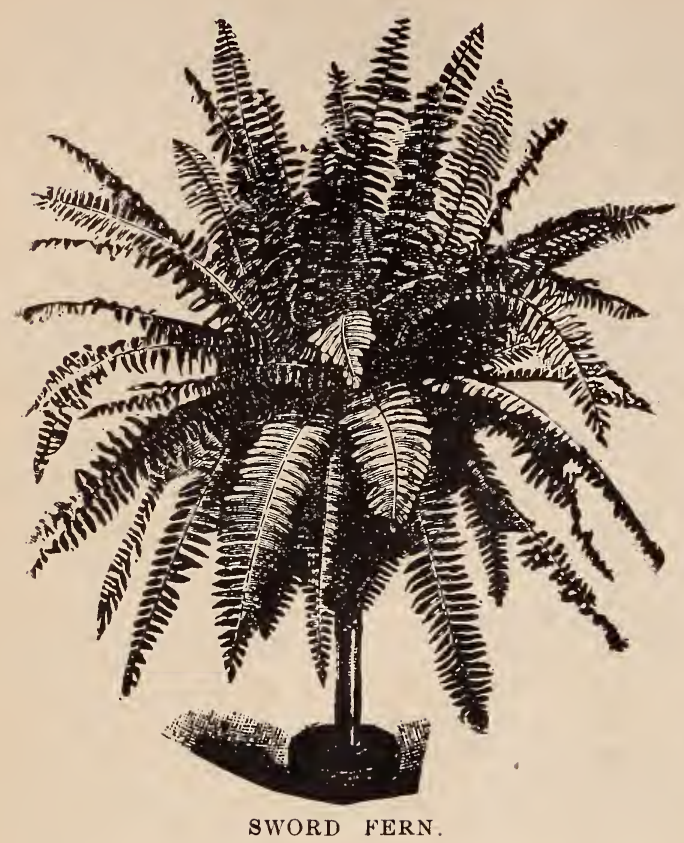

\section{FINE FERNS.}

BOSTON SWORD FERN.-One of the most popular sorts. Splendid for pots, vases or hanging baskets, especially desirable grown in the wire hanging baskets in which they thrive well and make very ornamental plants. 25c, postpaid

MIKADO FERN BALL.-Quite a novelty from Japan and a beautiful thing when well grown, but it is rather difficule to grow them satisfactorily in the dry atmosphere of an ordinary house. Largely advertised in the east. In dormant state. Each $50 \mathrm{c}$ postpaid.

NEPHROLEPIS BOSTONIENSIS (Boston Fern).This is a popular plant. It makes one of the finest decorating plants every introduced. Will grow rapidly under all conditions and the price is within the reach of everyone. It is often called "Fountain Fern" on account of its graceful drooping habit. The fronds when fully matured, often reach a length of four feet. $25 \mathrm{c}$ postpaid.

ASPARAGUS SPRENGERII-It is a fine plant for hanging baskets, with graceful drooping fronds. Sometimes 4 feet in length. The color of the foliage is a rich shade of green and will retain its freshness for weeks after being cut. $15 \mathrm{c}$ each; 3 for $40 \mathrm{c}$ postpaid.

ASPARAGUS PLUMOSUS NANUS.-This variety is often called the Shaking Fern. Its fine, bright green, feathery foliage surpasses the Maiden Hair Ferm in delicacy of texture. The sprays, after being cut off, will last a long time and are indispensable as a sreen, in floral decorations. $15 \mathrm{c}$ each, postpaid; 3 for $40 \mathrm{c}$.

UMBRELLA PLANT.-This plant is as handsome as a fern or palm for decoration. It will grow in water and is useful for aquariums and fountains, Each 12c; $\hat{0}$ for $30 \mathrm{c}$ postpaid.

\section{Hardy Herbaceous Plants.}

To this class of plants belong those that are hardy and die down to the roots in the fall, and spring up again in the springtime. Once planted they live forever.

COREOPSIS LANCOLATA (Giant Golden).-This begins to bloom in June and continues until frost. It is a rich yellow: fine for cut flowers; very hardy and easy to grow. $12 \mathrm{c}$ each; 3 for $30 \mathrm{c}$ postpaid.

HELIOPSIS PITCHERIANUS (Orange Sunflower).-Blooms early and late, grows 4 or $5 \mathrm{ft}$. high; flower a deep yellow, of fine texture, 2 inches in diameter. Good for cutting. Price $12 \mathrm{c}$ each; 3 for $30 \mathrm{c}$ postpaid.

GERMAN IRIS (The True Fleur de Lis).-These produce large, fragrant, orchid-like flowers, embracing many shades of color. Price each 10c; 6 for $50 \mathrm{c}$ postpaid.

JAPANESE IRIS.-This truly lovely Iris is among the most desirable summer flowering plants; many flowers measure from 10 to 12 inches in diameter. $12 \mathrm{c}$ each; 6 for $60 \mathrm{c}$ postpaid.

LILY OF THE VALLEY.-These dainty flowers should be in a moist, shady location. Once planted, the crowns increase each year, soon making a large bed, which blooms every year Strong flowering crowns; 6c each; 12 for $50 \mathrm{c}$ postpaid.

BLEEDING HEART.-One of the fine old favorites of Grandmother's garden. Produces rose colored heart-shaped flowers in abundance in April and May. Strong roots. Each 15c; 3 for $40 \mathrm{c}$ postpaid.

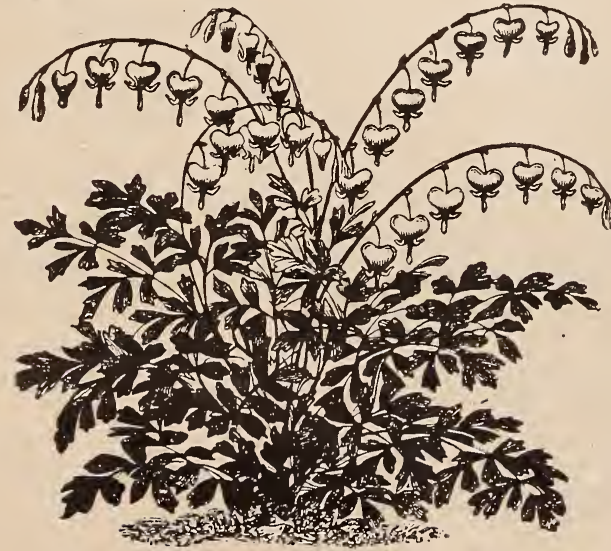

BLEEDING HEART

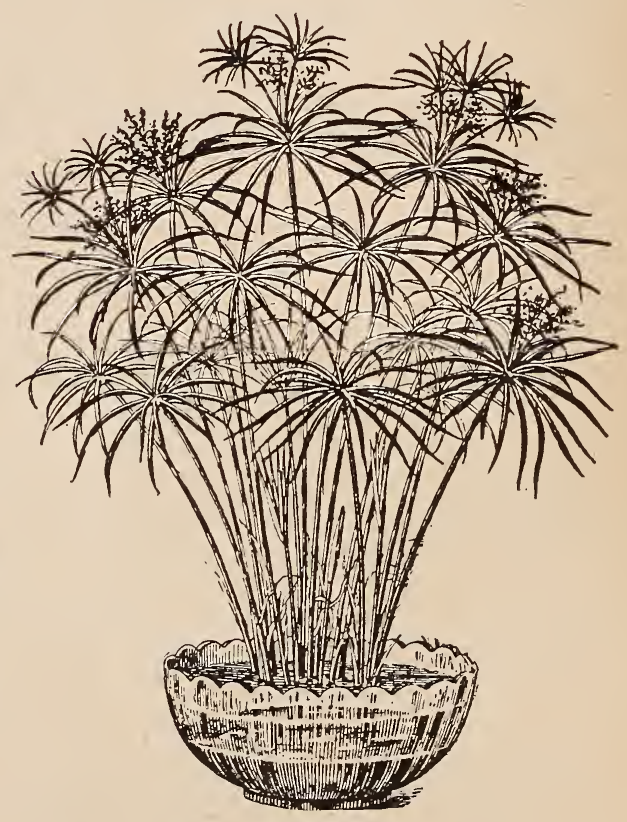

UMBRELLA PLANT

\section{Coleus Plants.}

12c each; 3 for 30 c postpaid.

COLEUS OR FOLIAGE PLANT.-We offer a variety of Coleus, some of the most desirable for bedding.

GOLDEN BEDDER.-Deep yellow variet.y.

FIRE GRAND.-Dark crimson, shaded garnet. JOHN GOOD.-Light green, spotted yellow. VERSCHAFELTII.-Rich velvety crimson. 


\section{POUlTRY SUPPlies.}

Oyster Shell, 50 lbs 45c.: 100 lbs 75c ; 200 lbs $\$ 1.30$,

Granulated Bone, 10 lbs 30c.; 50 lb。 $\$ 1.25 ; 100$ lbs $\$ 2.20$.

Bone Meal, Same price as Granulated Bone.

Mica Grits, 25

25c.; 50 lbs 50c.; 100 lbs 90 c.

Blood Meal or Dried Blood, $20 \mathrm{lbs} 90 \mathrm{c}$. ; $50 \mathrm{lbs} \$ 2.00 ; 100 \mathrm{lbs} \$ 3.50$.

Beef Meal, 10 lbs 30c. ; 50 lbs $\$ 1.25 ; 100 \$ 2.20$.

Beef Scraps, Same price as Beef Meal.

Aluminum Leg Bands, All numbered. 25 for $30 \mathrm{c}$.; 50 for $45 \mathrm{c}$; 100 for $75 \mathrm{c}$ Give breed of fowls for which the bands are wanted, (If wanted by mail add 4c per 100)

Nest Eggs, 2 for $5 c$. ,

Egg

Boxes, Always ready for use. No packing or tying; seals itself and cannot be opened without detection. 1 setting size. $15 \mathrm{c}$.; 2 setting size, $25 \mathrm{c}$

Drinking Fountains, self-feeders, chick size 25c each ; hen size, $50 \mathrm{c}$ each,

WE CARRY A COMPLETE LINE OF

\section{LEE'S Poultry Goods,}

LEE'S LICE KILLER-It never fails; just spray or paint roosts and nests and all lice and mites will disappear. No handling of fowls. Qt can 35c., 1/2 gal 60c.; gal \$1.oo.

LEE'S EGG MAKER-Furnishes the material the egg-producing organs require. Has no equal, 25c. and $50 \mathrm{c}$.

LEE'S GERMOZONE-Will cure the worst cases of Roup, Swelled Head, Colds, etc. A few drops in the water keeps them in condition all winter. 50c postpaid.

LEE'S INSECT POWDER-Kills lice, mites and all insects. 25c per box,

MANDY LEE INCUBATORS AND BROODERS

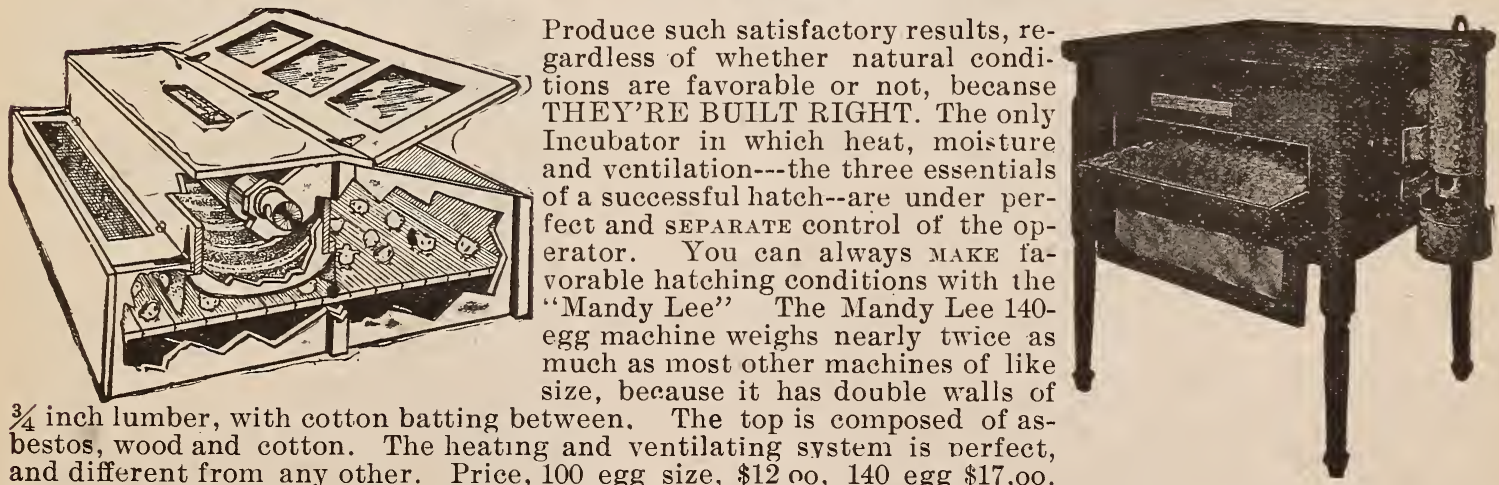

The "Mandy Lee" Brooder is the only direct contact heat brooder made---the only brooder that hovers exactly like the hen. No crowding in the Mandy Lee. Strong chicks, because they are comfortable and breathe fresh, pure air. Price $\$ 12$.0o. We pay freight on Incubators and brooders. Write US for catalogue of these machines. They are built right. Address Zrmmerman Seed Co., Topeka, Kans.

\section{ZIMMERMAN'S PURE GRAIN POULTRY FOOD.}

Is composed of Sound. Wholesome Grain. No floor-sweepings, dirt and trash in it. Looks better, tastes better and IS BETTER, richer, purer and will go farther than that generally sold, IT COSTS NO MORE, TRY IT. You will be pleased with the QUALITY. $100 \mathrm{lbs} \$ 1.25 ; 2$ oo lbs $\$ 2.30$

\section{Purina Baby Chick Feed.}

Awarded Grand Prize at World's Fair, St Louis. More chicks die when 4 to 12 days old than at any other time: Clean grain, seed and muscle material is what they need. This chick food contains the above in proper proportions and is fed regularly by the most experienced poultry raisers. With proper care and attention, this food will raise every chice. $25 \mathrm{lbs} 7 \mathrm{oc}$.; 5 o lbs $\$ 1.30 ; 100 \mathrm{lbs} \$ 2.4 \mathrm{o}$. 


\section{CELEBRATED ROOT BEE SUPPLIES}

\section{DOVETAILED HIVE FOR COMB-HONEY.}

This hive takes the $41 / 4 \times 41 / 4 \times 11 / 2$ plain or no-beeway section.

This hive is furnished in eight-frame size. It consists of a bottomboard, A; a cover, E; a body or brooding-chamber, with Hoffman frames and a division-board, 5; or with inch foundation starters, 6; 4\%-inch super with plain section-holders, $P$; fences, springs, and end wedges, 2P; or with $41 / 4 \times 41 / 4 \times 41 / 2$-inch sections and inch foundation starters, 4P. When two supers are included with each hive it is then a 2-story hive for comb honey.

AE52P-8-No sections, starters, with one super With sections, starters, with one super......\$1.85 $\$ 8.50 \quad \$ 15.50$ two supersuper....... 2.15 AE644P-8 - With sections, starters, two supers........ 2.35 $10.75 \quad \begin{array}{ll}19.50 \\ 24.00\end{array}$ DOVETAILED HIVE FOR COMB-HÖEY

This hive takes the $41 / 4 \times 41 / 4 \times 17 / 8$, two-beeway section.

This hive is exactly like the one above, except in the inside furnishings of the super. The super of this hive is $43 / 4$ inches deep, with slotted section-holders, sawed separators, follower, and springs, 2S, or with $41 / 4 \times 41 / 4 \times 17 / 8$ two-beeway sections and foundation starters, $4 \mathrm{~S}$.

In ordering this hive, use the prices above, changing the letter $P$ to letter S. Both hives take the same price for the same size and furnishings, therefore we do not repeat the prices here.

\section{DANZENBAKER COMB-HONEY HIVE.}

This hive takes $4 \times 5 \times 13 / 8$-inch plain or no bee-way sections. made only in ten-frame size (161/4 inches wide).

AEDj-No super or fdn. starters................... In flat. Five. Ten. AED 6-No super, with fdn. starters....................1.50 $\$ 6.75 \$ 12.50$ AED52M-With super, no sections or starters........... $2.10 \quad 9.75 \quad 18.00$ AED 64M-Complete with springs, sections, starters... 2.40 $11.00 \quad 20.50$

Nailed and painted, 75c each extra.; COVER.

Furnished with all our hives

DANZENBAKER BOTTOM-BOARD WITH DETACHABLE ALIGHTING-BOARD.

The standard bottom-board, which is furnished with all our hives, PORTER BEE-ESCAPE.

Price, 20c each; $\$ 2.25$ per dozen, prepaid.

Price with board, $35 \mathrm{c} ; \$ 3.20$ for 10 , not postpaid.

Style 2.-Beeway, open top and bottom

Style 5.-Plain, no beeways. Used with fences.

Style $5 \mathrm{M}$. - 4x5x1\%, plain, no beeway. Used in Danzenbaker hives.

Price best grade, any style, 100 fur $75 \mathrm{c}, 250$ for $\$ 1.50$, 500 for $\$ 2.55,1,000$ for $\$ 5.00$ FOUNDATTON

Medium Brood, $1 \mathrm{lb} 55 \mathrm{c}, 5 \mathrm{lbs} \$ 2.65,10 \mathrm{lbs} \$ 5.10,25 \mathrm{lbs} \$ 12.25$

Thin Super, $1 \mathrm{lb} 62 \mathrm{c}, 5 \mathrm{lbs} \$ 3.00$. $10 \mathrm{lbs} \$ 5.75,25 \mathrm{lb} \$ \$ 14.00$.

Extra Thin Super, 1 lb 65c., 5 lbs $\$ 3.15,10$ lbs $\$ 6.00,25$ lbs $\$ 14.75$.

\section{SMOKERS.}

Price, Standard Root, 31/4-in., 85c each; $3 \quad \$ 2.25$; postage, 25c. PARKER'S FOUNDATIÓN FASTENER.

Price, for 1-1.b. sections. 25c; by mail, 15c extra. PERFORATED ZINC.

Used to confine the queen to the brood-chamber

Price, for 8-frame hive, $15 \mathrm{c}$ each; 10 for $\$ 1.20$. For 10 frame hive, $18 \mathrm{c}$ each; 10 for $\$ 1.40$.

\section{ALLEY'S OUEEN AND DRONE TRAP.}

Price 50c; 10 for $\$ 4.00$; by mail, 15c each extra.

BEE VEILS.

Bottom tulle, with silk face Price 50c.

THE HOFFMAN BROOD FRAME.

Beginners and even careless bee-keepers of some experience can not fail to get them spaced just right. There is no guessing or haphazard fingering; and the consequence is, the combs are even in surface, and of uniform thickness. In these days, when out-apiaries are so much in vogue, and hives are moved from one point to another, it is highly important that the frames be of a kind that will stand hauling from place to place, even over rough roads; and in this rehauling from place to place, even over rou

soct the Hoffman fills the bill perfectly; 100 for $\$ 2.75 ; 500$ for $\$ 12.50$. DOVETAILED PLAIN-SECTION SUPER.

This super takes $4 \frac{1}{4} \times 4^{1 / 4} \times 1 \frac{1}{2}$ plain or no bee-way sections.

We sure section $41 / x 4^{1}$ A fence is used between each two-section holder and at tion $41 / 4 \times 41 / 4$. A fence is used between each two-section holder and at wedges and three springs on one side.

2P-8-Without sections \& foundation starters, 8-frame... $\$ 0.50 \quad \$ 2.25$ Ine. Ten $\begin{array}{llll}4 \mathrm{P}-8 \text {-With sections and foundation starters, 8-frame.. } & .70 & \$ 2.25 & \$ .00\end{array}$ DOVETAILED SLOTTED-SECTION SUPER

This super takes $41 / 4 \times 41 / 4 \times 17 / 8$ beeway section.

This is the old style of super and section most commonly used, and the one to order if you prefer to use square beeway section $41 / 4 \times 41 / 4 \times 17 / 8$. In flat. Five. Ten.

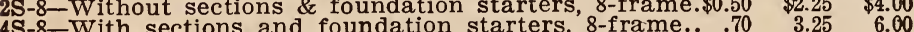
DANZENBAKER SECTION SUPER.

This super takes $4 \times 5 \times 13 / 8$ plain or no-beeway sections.

In flat. Five. Ten. $2 M-10-$ Without sections and fdn. starters, 10 -frame...\$0.70 $\$ 3.25 \$ \$ 6.00$ 4M-10-With sections and fdn. starters, 10-frame.....

Price in cloth, $\$ 1.20$; in half leather, $\$ 1.75$; in full leather, $\$ 2.00$. If sent by freight or express, deduct 20 cents from any of the above prices.
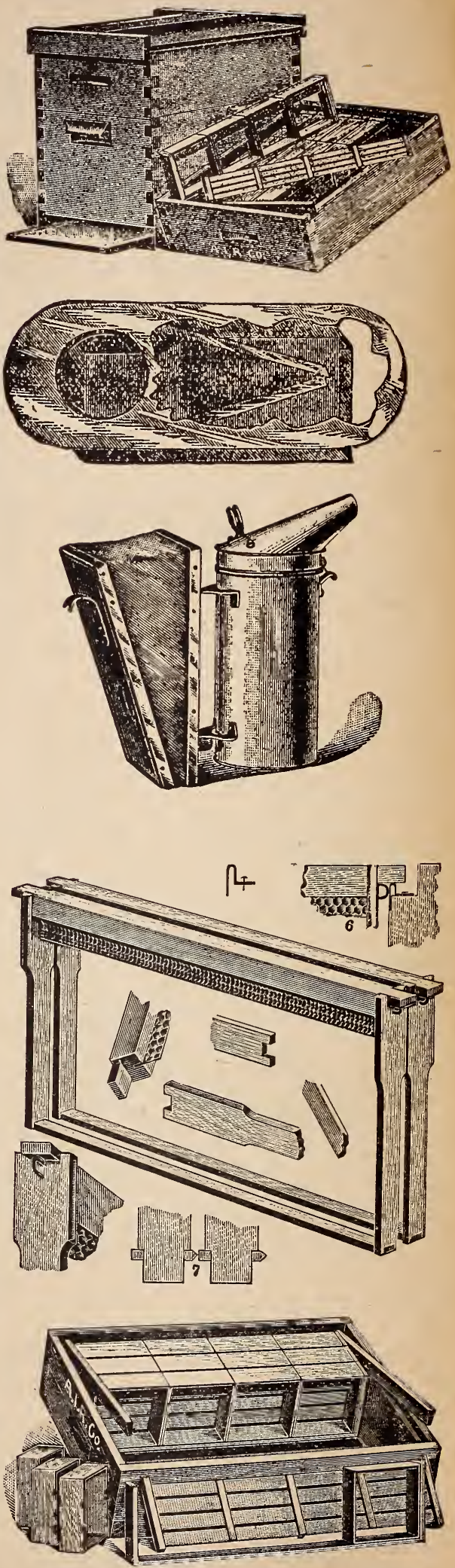
MARKET GARDEN ERS.

No order for less than $\$ 5.00$ will be accepted at these prices. Our prices on Onion seed is so low and stock limited, that not over $1 / 2$ of any order can be Onion Seed. Shipments made by express or freight not prepaid.

$1 / 21 \mathrm{lb}$ at lb rate: $1 / 2$ peck at peck rate; $1 / 2$ bu at bu rate. Cash in full must accompany all orders. We hope to receive your order and will give it our prompt and careful attention.

\section{ASPARAGUS.}

Pkt. oz. 1/4 lb. lb.

Palmetta. . . .............. 03 07 $15 \quad 40$

Conover's Colossal. ......... $03 \quad 07 \quad 12 \quad 35$

BEANS

$1 / 2$ pt. pint qt. pk.

Stringless Green Pod........ $10 \quad 15 \quad 20 \quad \$ 130$

Early Red Valentine. ...... $08 \quad 10 \quad 15 \quad 100$

Stringless Red Valentine.... $10 \quad 15 \quad 20 \quad 130$

Round Yellow Six Weeks.... 08 $08 \quad 12 \quad 18 \quad 115$

White Kidney. . . ............ $10 \quad 12 \quad 18 \quad 115$

Large White Marrofat...... $10 \quad 12 \quad 18 \quad 115$

Currie's Rust Proof Wax.... $10 \quad 12 \quad 15 \quad 110$

Zimmerman's German Wax. $10 \quad 12 \quad 18 \quad 115$

Wardwell's Kidney Wax.... $10 \quad 15 \quad 25 \quad 160$

Dwarf Black Wax........... $10 \quad 15 \quad 20 \quad 115$

Davis' Kidney Wax.......... $10 \quad .15 \quad 25 \quad 160$

Burpee's Bush Lima......... $10 \quad 15 \quad 20 \quad 140$

Henderson's Bush Lima..... 10 $10 \quad 15 \quad 20 \quad 140$

Kentucky Wonder, Pole..... $10 \quad 15 \quad 20 \quad 140$

Lazy Wife, Pole............. $10 \quad 15 \quad 20 \quad 140$

Cutshort or Cornhill, Pole.. $10 \quad 15 \quad 20 \quad 140$

King of the Garden Lima, Pole. ................. $10 \quad 15 \quad 20 \quad 140$

Golden Cluster Wax........ $10 \quad 15 \quad 25 \quad 150$ GARDEN BEETS.

Pkt. oz. 1/4 lb. lb

Crosby's Egyptian........... $03 \quad 06 \quad 12 \quad 35$

Extra Early Egyptian....... $03 \quad 06 \quad 12 \quad 35$

Edmand's Blood Turnip..... $03 \quad 06 \quad 12 \quad 35$

Early Eclipse.............. $03 \quad 06 \quad 12 \quad 35$

Extra Early Lentz.......... $03 \quad 06 \quad 12 \quad 35$

Zimmerman's Electric. ..... 03 $08 \quad 15 \quad 45$

Dewing's Improved Blood... $03 \quad 06 \quad 12 \quad 35$

Half Long Blood............. $03 \quad 06 \quad \mathbf{1 2} \quad 35$

Swiss Chard. . . . B........ 03 08

Golden Tankard Mangel....

Improved Mammoth Prize

Mangel. ...................

Long Red Mangel............

Red Globe Mangel............

Lane's Imperial Sugar......

Impvd, Wanzleben Sugar...

BROCCOLI.

Lnrge White. . .......... 05 $20 \quad 75 \quad \$ 250$ BORECOLE OR KALE.

Dwarf German Green Curl'd 03 08
BRUSSELS SPROUTS.

Perfection. . . .............. 03 12 CABBAGE. $12 \quad 40 \quad \$ 135$

$04 \quad 08 \quad 15$

15

bu.

$\$ 500$

500

$\begin{array}{lll}5 & 00 \\ 4 & 00\end{array}$

400
400

400

375

400

600

400

600

475
440

$\begin{array}{ll}4 & 40 \\ 5 & 00\end{array}$

500

(

50

550

,

All Head Early.............. 03

Early Jersey Wakefield..... 03

Early Winnigstadt............ $\theta 3$

Zimmerman's Earliest....... 03

Extra Early Etampes........ 03

Early Summer. . . .......... 03

Early Express............... 03

Zimmerman's Surehead...... 03

Giant Flat Dutch............ 03

Short Stem Drumhead....... 03

Large Late Drumhead....... 03

St. Louis Market............ 03

Danish Ball Head or Hol'dr 03

All Seasons................. 03

$15 \quad 30 \quad 110$

$15 \quad 30 \quad 100$

$15 \quad 30 \quad 100$

$15 \quad 40 \quad 115$

$15 \quad 30 \quad 110$

$15 \quad 30 \cdot 110$

$15 \quad 30 \quad 100$

$1230 \quad 100$

$12 \quad 30 \quad 100$

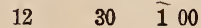

$15 \quad 30 \quad 100$

$\begin{array}{lll}18 & 40 & 150\end{array}$

$15 \quad 40 \quad 130$

$15 \quad 30 \quad 100$

Mammoth Red Rock........ 03 $18 \quad 40 \quad 130$

CAULIFLOWER.

Earl Snowball. . .............

Dwarf Erfurt. . . ............... 15

Early Paris Forcing.......... 05

\section{Z}

Boston Pickling..............

White Pearl.................. 03

Early Russian................ 03

New Everbearing............ 03

Improved Long Green....... 03

Cool and Crisp................ 03

EGG PLANT.

Improved Large Purple.... $04 \quad 30 \quad 80 \quad \$ 250$

ENDIVE.

Green Curled............... 03 08
GARLIC.

$\begin{array}{llll}\text { KOHL-RABI. } & & \\ \text { White Giant................ 03 } 15 & 40 & 140\end{array}$

Giant Purple................ 03 $15 \quad 40 \quad 140$

Ox-Heart or Guerrande..... 03

Improved Long Orange...... 03

Large White Bergian........ 02

$\begin{array}{lcl}\text { oz. } & 1 / 4 \mathrm{lb} & \mathrm{Ib} . \\ 08 & 15 & 40 \\ 08 & 15 & 40 \\ 08 & 15 & 40 \\ 08 & 15 & 40 \\ 06 & 11 & 28 \\ 06 & 11 & 25\end{array}$

$70 \$ 200$

$50 \quad 170$

120

$\begin{array}{lll}40 & 150 \\ 30 & 1 & 00\end{array}$

$30 \quad 100$

$40 \quad 140$

20

55

75

pk.

$$
75
$$

bu.

$\$ 250$

225

225

250

225

250

200

200

259

$25 \mathrm{lbs}$.

05

05

05

75

75

75

Zimmerman's Earliest....... 03

Early Curled Simpson...... 03

Black Seeded Simpson...... 03

New Morse................. 03

Improved Hanson........... 03

California Cream Butter..... 03

Iceberg. . . ................ 03

Early Prize Head........... 03

Denver Market............. 03

Hard Head................. 03

MUSMROOM SPAWN.

In Bricks.................

White. . . .................. 03

Brown. . .................. 03

Southern Giant Curled...... 03

$\begin{array}{lll}05 & 10 & 25 \\ 05 & 10 & 25 \\ 07 & 18 & 45\end{array}$


MUSK MELON.

$\begin{array}{cccc}\text { Pkt. } & \text { Oz. } & 1 / 4 \mathrm{lb} . & 1 \mathrm{~b} \\ \text { Zimmerman's Earliest L'rge } 03 & 10 & 20 & 70\end{array}$

Extra Early Hackensack.... 03

Rocky Ford................ 03

Oklahoma. . . .............. 03

Banana. ................... 03

Grand Rapids............. 03

Zimmerman's Excelsior...... 04

Emerald Gem............... 04

Osage. . ..................... 03

Miller's Cream............. 03

Improved Montreal Market. 03

WATER MELON.

Harris' Earliest.............. 04

Home Favorite............. 03

Black Diamond.............. 03

Rattlesnake. . . ............ 03

Peerless or Ice $\sim$ ream....... 03

Mammoth Ironclad.......... 03

Mountain Sweet............ 03

Sweetheart. . .............. 03

Kentucky Wonder............ 03

McIver's Sweet.............. 03

Triumph.................. 03

King of Mammoths......... 03

Kleckley's Sweet............ 03

Kolb's Gem................. 03

Citron. ................ 04

ONION SEED.

Yellow Globe Danvers...... 04 04

Australian Brown........... $04 \quad 09$

White Portugal or Silver

Skin. . . ................. 04

Southport Red Globe......... 04

Southport White vlobe...... 04

Large Red Wethersfield..... 04

American Prize-Taker...... 04

Barletta. . ................. 04

Mammoth Silver King....... 04

White Bermuda. . . ......... 04

OKRA.

White Velvet............... 03 ONION SETS.
ONO

$1 / 2$ pt. pint

Yellow Bottom

Red Bottom.......

White Bottom

PEAS

Two Weeks Early........... 10

Little Gem................. 10

Alaska. . . ................. 10

Gradus or Prosperity........ 12

Improved Stratagem........ 10

Nott's Excelsior............. 10

Zimmerman's Reliance...... 12

Yorkshire Hero............. 10

Telephone. . . ............... 10

Zimmerman's Mammoth..... 10

Bliss' Everbearing.......... 10

Dwarf Sugar................ 10

White Marrowfat........... $08 \quad 12$

PUMPIKINS.

Pkt.

Thanksgiving Pie........... 03

small Sugar................... 03

Japanese Pie................ 03

Cashaw. . . ................... 03

Small Sugar................ 03

King of the Mammoth....... 03

Common Field............... 02

PEPPER

New Mammoth.............. 04

Ruby King................... 03

Celestial. . ................. 03

Procopp's Giant.............. 03

Long Red Cayenne.......... 03

Red Chili.

$\begin{array}{cc}1 / 4 \mathrm{lb} . & \mathrm{lb} \\ 20 & 70 \\ 18 & 60 \\ 15 & 50 \\ 20 & 70 \\ 15 & 50 \\ 15 & 55 \\ 25 & 90 \\ 18 & 65 \\ 18 & 60 \\ 18 & 60 \\ 18 & 60\end{array}$

$\begin{array}{lll}08 & 20 & 75\end{array}$

15

$06 \quad 12 \quad 40$

$06-15 \quad 40$

$06 \quad 15 \quad 40$

$06-15 \quad 40$

$06 \quad 15 \quad 40$

$08 \quad 15 \quad 45$

$08 \quad 15 \quad 45$

$08 \quad 18.50$

$08 \quad 18 \quad 50$

$08 \quad 18 \quad 50$

$\begin{array}{lll}07 & 15 & 40\end{array}$

$12 \quad 40$

$20 \quad 60$

$35 \quad \$ 120$

$25 \quad 90$

$40 \quad 135$

$10 \quad 140$

$55 \quad 180$

$35 \quad 115$

$\begin{array}{lll}40 & 140\end{array}$

$40 \quad 135$

$40 \quad 135$

$75 \quad 250$

$15 \quad 40$

qt. pk.

$\begin{array}{lr}\text { qt. } & \text { pk. } \\ 15 & 65\end{array}$

$15 \quad 65$

15

$20 \quad 125$

$20 \quad 125$

$18 \quad 100$

$25 \quad 175$

$20 \quad 130$

$20 \quad 130$

$25 \quad 160$

$20 \quad 125$

$20 \quad 130$

$25 \quad 140$

$20 \quad 110$

$25 \quad 165$

$18 \quad 110$

$1 / 4 \mathrm{lb} . \quad \mathrm{lb}$

1540

$18 \quad 50$

$18 \quad 50$

1540

$25 \quad 30$

1530

$20 \quad 50 \quad 175$

$12 \quad 40 \quad 140$

$12 \quad 40 \quad 140$

$\begin{array}{lll}12 & 40 & 140\end{array}$

$12 \quad 40 \quad 140$
$18 \quad 50$

$\begin{array}{lll}12 & 40 & 140\end{array}$
PARSNIP.

Pkt. oz. 1/4 lb. lb

$\begin{array}{lllll}\text { Hollow Crown Sugar......... } 03 & 07 & 12 & 30 \\ 07 & 12 & 30\end{array}$

PARSLEY.

Champion Moss Curled...... 03 08 08 15 40

New Emerald............... 03 08 $15 \quad 40$

RADISH.

New Lightning.............. 04

Early Scarlet Globe......... 03

Rosy Gem................ 03

Early Turnip Red.......... 03

French Breakfast........... 03

New Leafless................ 04

Olive-Shaped Rose.......... 03

White Olive-Shaped......... 03

White Strasburg............ 03

New White Chinese......... 03

Rose China Winter......... 03

Crimson Giant............... 03

White Icicle............... 03

Long Scarlet Short Top...... 03

Long White Lady Finger.... 03

California Mammoth Winter 03

RHUBARB.

Victoria Giant............... 03
SPINACH.

New Long Standard......... $03 \quad 05-10 \quad 25$

Round Thick Leaved......... $03.05 \quad 10 \quad 20$

Prickly Winter............. 03 05 051025

Savoy Leaved............... $03 \quad 05 \quad 10 \quad 25$

Bloomsdale. ............... $03 \quad 05$

SALSIFY.

Mammoth Sandwich Island. 03

SQUASH.

Warty Hubbard.............. 04 04 08 20 60

Mammotn Hubbard......... 04

Golden Hubbard............ 04

White Bush Scallop......... 03

Summer Crookneck.......... 03

Sibley. . . .................. 04

Blue Marblehead............ 03

TOMATO.

Early Wonder................ 04

bu. Earlina. . . ................ 04

\$2 30 Zimmerman's Impvd. Tree.. 04

230

250

450

Gold Dust (Red)........... 04

Western Giant............... 04

Early Beauty................ 03

450

375

Magnus. . ................. 03

New Stone................. 03

Matchless. . . ............... 03

650

450

475

600

450

450

5 ग0

390

690

380

Paragon. . . ................... 03

Ponderosa. . . ................... 03

Golden Queen. ............. 03

Dwarf Cnampion.............. 03

TURNIP

Early White Milan.......... 03

Purple Top Milan........... 03

Early White Flat Dutch..... 03

White Egg. . ............... 03

Purple Top Strap Leaved... 03

Cow Horn.................. 03

Seven Top.................. 03 08

POTATOES

pk. bu. bbl. (23/4 bu.)

Early Delight................ 35 $\$ 110 \quad \$ 300$

Early Ohio.................. 35 $120 \quad 270$

Early Six Weeks............. $30 \quad 100 \quad 270$

Triumph $\quad$.................... 35 $110 \quad 300$

Burbank. ................. 35 $110 \quad 300$

SWEET POTATOES.

Yellow Jersey............... 40 120.300

Yellow Nansemond........... $40 \quad 120 \quad 300$

Red Jersey..................... $40 \quad 140 \quad 330$

Red Nansemond.............. 40 $140 \quad 330$

Bermuda Red................. $40 \quad 140 \quad 330$ 


\section{ORDER SHEET. ZIMMERMAN SEED CO., THANSAS.}

Date 1907.

Name

(Write your name ploin and distinct.)

Post Orrice

AMOUNT ENCLOSED.

County

State

Send This Order by

State whether by Mail, Express or Freight.

Express Once

Freight Offee

When ordered by express or freight, give express or freight office.

Express Order

Post Office Order $\$$

Cash - - \$

Draft - - \$

Stamps - - \$

Postpaid by Mail. We pay the postage on packets, ounces, $1 / 4 \mathrm{lbs}, 1 / 2 \mathrm{lbs}, 1 \mathrm{bs}$, pints and quarts, All you have to do is to make out a list of the seeds wanted, attach the price to each and send the amount by money order, draft or registered letter. We assume all risks, - that is, we guarantee the seed will arrive promptly and in good condition.

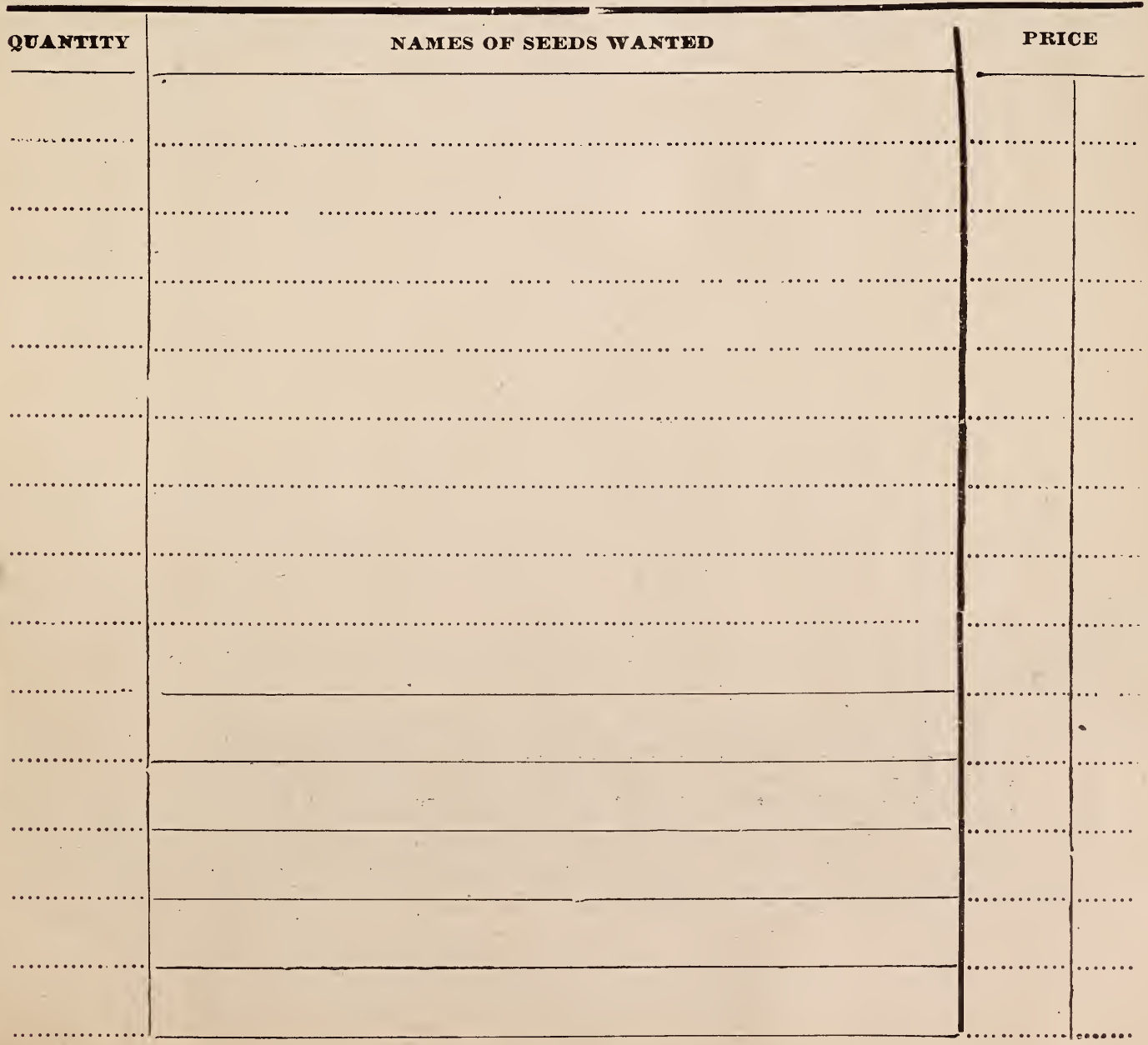




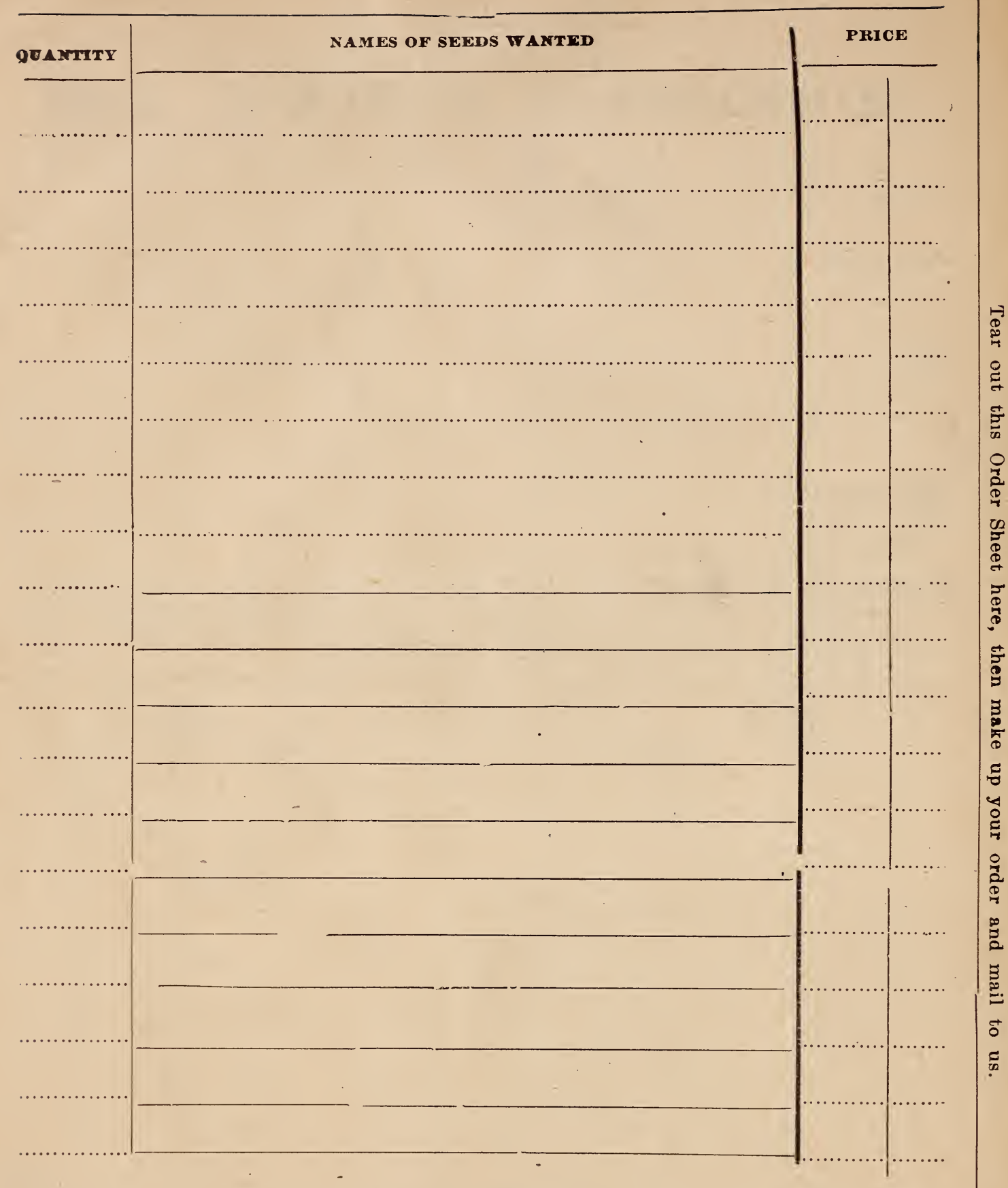

NOTE-Before making out your order, please read directions as given on the inside of Front Cover of Catalogue.

\section{LIST OF FREE SEEDS.}

For every ONE DOLLAR order for seeds in PACKETS and OUNCES, you are entitled to select TWENTY-FIVE CENTS worth in PACKETS and OUNCES FREE. Write your FREE selections in the spaces below. In addition, we always send several choice varieties FreE, as pres ?nts.

Our book, "Success with Seeds," giving the proper cultivation of almost everything, is sent Free with a One Dollar order, if asked for. 


\section{Vegetables.}

Artichoke...................3

Anise......................31

Asparagus.................. 3

Beans.

$\ldots, 4,5$

Beets.....................6

Broccoli...................

Brussels Sprouts .......... 14

Borage...................31

Cabbage............ . . 7,8

Carrot......

Cuuliflower

Caraway..

Catnip...

Celery ........

Chicory.

Collards . .

Coriander.

Curn, Pop...

Corn, sweet

Cucumber.

Dill...

Eqg Plant.

Endive....

Garlic..........

Horehound...

Hop Seed.

Kohl-Rabi ....

Lavender.

Leek.... . .

Lettuce...

Melun, Musk.....

Melons, Water.....

…16. 17

Mushroom Spawn

$.18,19,20$

Mustard
Okra or Gumbo.

Onion ...................

$\ldots \ldots 22$

Parsley ......................25

Parsnip..................25

Peanuts...................14

Peas.......... .......23.24

Pepper.....................25

Pumpkin ...................25

Potatoes....................36

Radish ................26. 27

Rhubarb................22

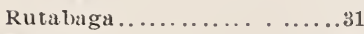

Salsify................20

Saff ron ........................

Sage $\ldots \ldots \ldots \ldots \ldots \ldots \ldots . . . . . . . . .31$

Savory.........................

Spinach.................22

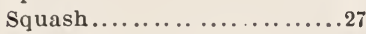

Thyme....................

Tomato.............28, 29, 30

Turnip....................31

Flowers and Bulbs.

Abutilon..................40

Ageratum.................40

Alyssum ................40

Amaranthus.............. 40

Antirrhinum ............4 40

Aster.....................41

Balsam..................42

Begonia..................52

Bird of Paradise.............42

Cannas...............45,

Carnations...............42

Candytuft.................44
Celosia ... ..............42

Centaurea..................43

Chrysanthemum...........44

Cineraria.................42

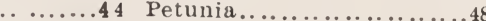

Coleus .... .........43, 56 Phlox....................48

Cosmos... ... ... .......43 Poppy...................4

Cypress Vine...............53 Portulaca.....................

Caladium.................52 Primula...............48

Cinnamon Vine............54 Ricinus.................... 49

Canary Bird Flower........53 Salvia or Scarlet Sage......48

Cubæ Vine.... .........53 Sensitive Plant............49

Dahlias.............43, 52 Sinilax.................48

Datura................45 stocks..................49

Dianthus................t4 sunflower...............49

Escholtzia (Cali. Poppy)....43 Sweet Peas............50, 51

Feverfew...............43 Sweet William..........49

Fuehsla...............43, 56 Tuberose...............53

For-Get-Me-Not ...........43 Verbena................51

Gaillardia...............44 Wistaria...............57

Geranium............45, 56 Zinnia...............51

Gladiolus.................53

Gloxiania..................5

Heliotrope.................45

Hollyhock................44

Hyacinth Bean .............. 53

Ice Plint.................44

Kenilworth Ivy .............48

Larkspur................44

Lobelia.....................45

Madeira Vine...............57

Marigold..................45

Marvel of Peru..............45

Mignonette..............44

Mimulus................45

Morning Glory .............. 53

\section{Field Seeds.}

Pages 32 to 39

Roses and

Plants.

Pages 54, 55, 56 and 57

Poultry and

Bee Supplies

Etc.

Pages 58, 59 and 60 .

\section{Quantity of Seeds and Roots Required.}

Artichoke, oz of seed to 500 plants.

Asparagus, oz of seed for 500 plants

Barley. 2 bu per acre

Beans, dwarf. $1 \frac{1}{2}$ pt to 100 feet of drill; $1 \frac{1}{4}$ bu per acre

Beans, pole, one qt to 100 hills

Bect, one $o z$ to $10 \mathrm{~J}$ feet of drill: 5 to 6 lbs per acre

Brussels Sprouts, one oz to 5,000 plants

Buckwheat, $1 / 2$ bu per acre

Blue Grass, 12 to $251 \mathrm{bs}$ per acre

Cabbage, one oz to 3,000 plants

Carrot, $1 / 2$ oz to 100 feet of drill; 2 to 3 lbs per acre

Caulifiower, one $\mathrm{o} z$ to 3,000 plants

Celery, one oz to 10.000 ) plants

Corn, one qt to 200 hills; 8 to 10 lbs per acre

Cucumbers. one oz to 100 hills

Egg Plant, one 0z, to 2,000 plants

Endive, $1 / 4$ oz to 100 feet of drill

Grass, Orchard, $20 \mathrm{lbs}$ per acre

Grass, Lawn, one lb to $400 \mathrm{sq} \mathrm{ft}$ : $100 \mathrm{lbs}$ per arre

Grass Tincthy, 15 to 20 l bs per acre

Grass, Red Clover, 12 to 15 los per acte

Grass, Bromus Inermis, 20 to 30 lbs per acre
Kale, one oz to 5,000 plants

Lettuce, $1 / 4 \mathrm{Oz}$ to 100 feet of drill

Melon, Musk, one oz to 100 hills; 2 to 3 lbs per acre

li elon, Water, one $a z$ to $: 0$ hills; 3 to 5 lbs per acre

Okra, one oz to 75 feet of drill

Onion seed one $o z$ to 200 fcet of drill; 5 lbs per acre

Onion seed for sets, 40 to 50 lbs per acre

Onion sets, one qt to 38 feet of drill; 6 bu per acre

Parsnip, $1 / 2$ oz to 100 feet of drill; 3 to 5 lbs per acre

Parsley, $1 / 2$ oz to 100 feet of drill

Peas, garden. one qt to 100 feet of drill: $1 \frac{1}{2}$ bu per acre

Peas, cow. $1 \frac{1}{2}$ bu per acre

Pepper, one 0 \% to 1.500 plants

Pumpkin, one oz to 75 hills: 5 lbs peracre

Radish, one $n z$ to 100 feet of ; rill; 6 to $81 \mathrm{lbs}$ per acre

Salsify, one oz to 75 feet of drill: 6 to 8 l bs per acre

Spinach, one oz to 100 feet of drill; 10 ths per acre

Squash, one oz to 75 hills; 5 lbs per acre

Tomato, one $n z$ to 2.500 plants

Tubacco, one oz to 3.500 plants; two 1 lus per acre

Turnip, one oz to 200 feet of drill, $1 \frac{1}{2} \mathrm{tbs}$ per acre

\section{Legal Weight Per Bushel.}

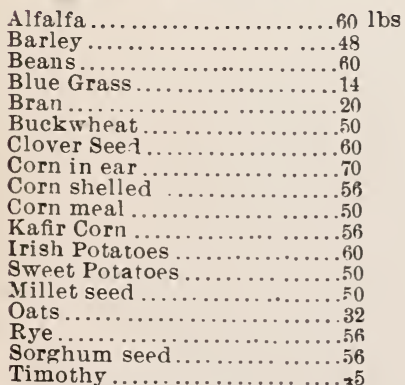

\section{If you wish any information l.}

given in this Catalog: $=2$, write us. We are always glad to hear from you. 
r.t.

,

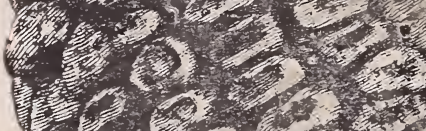

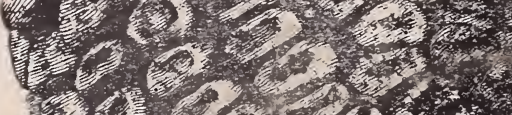

等

(1)

(n)

(n)

Out-yielded 80 Varieties

-

(3)

(a)

(6)

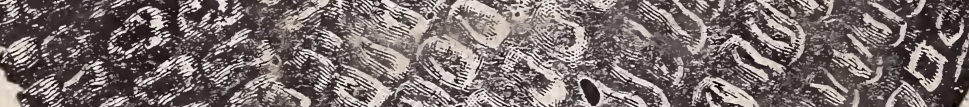

6.

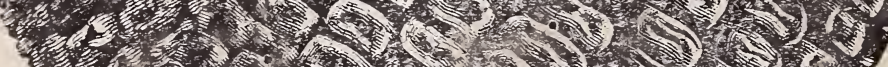

m.

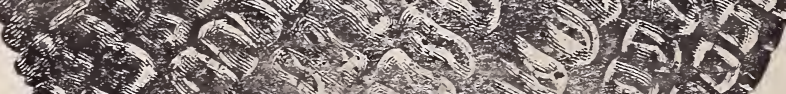

Kansas Agricultura] Col-

1905. (Where the

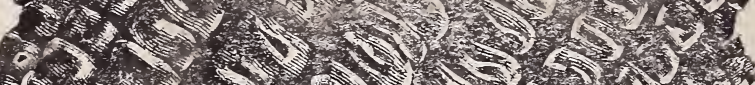

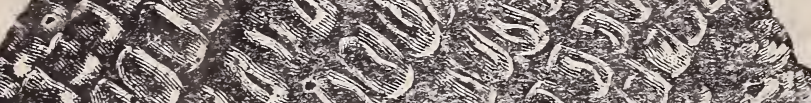
Awarded Prize at the

mount planted was equal)

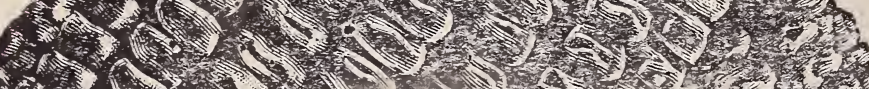
Kansas State Fair, Topeka, 1904.

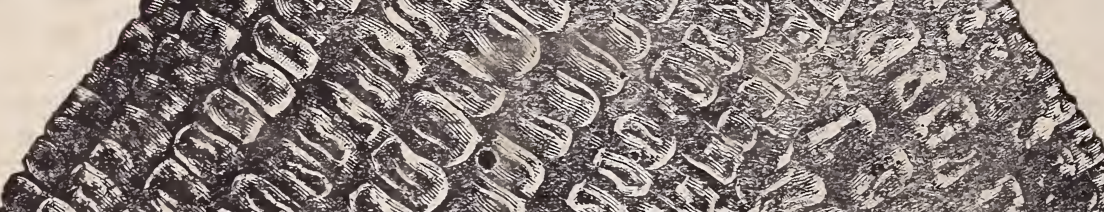

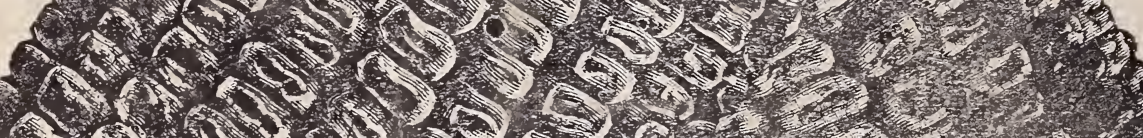
1
1

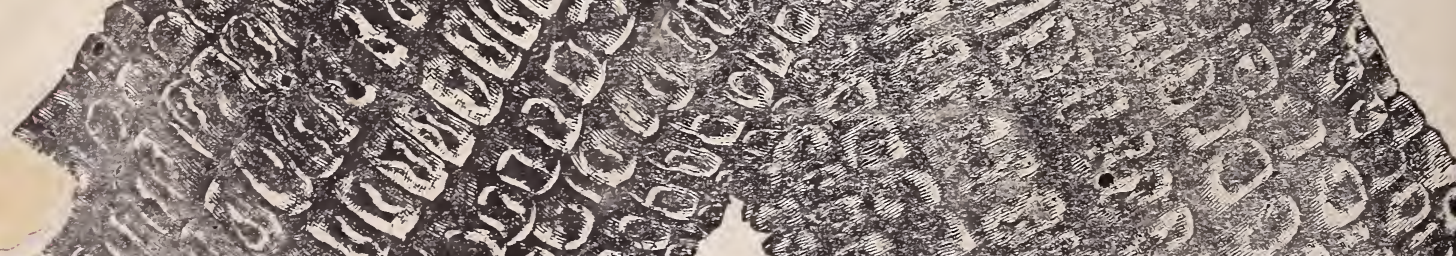

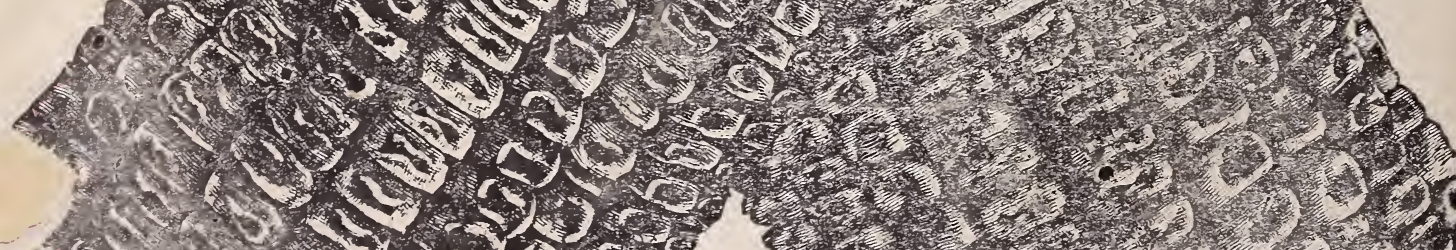
1
6

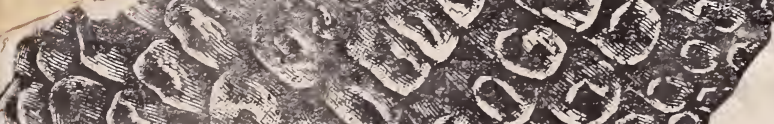

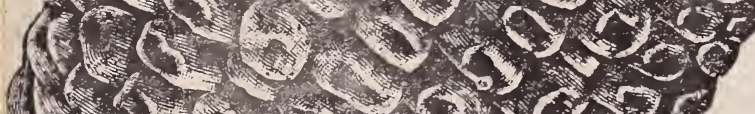

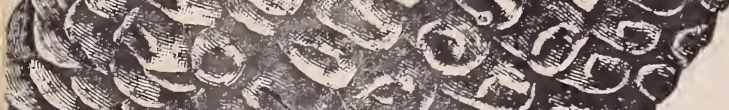

Le 1090

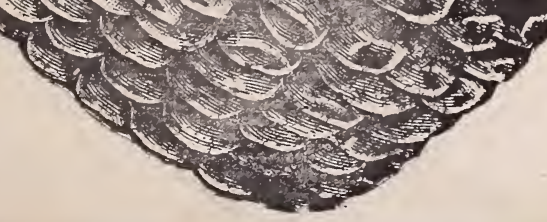

COMBINATION. $125,300 \%$

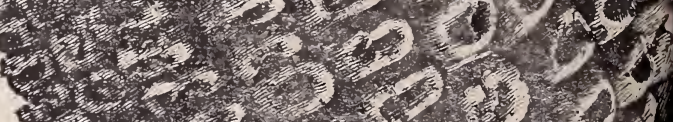

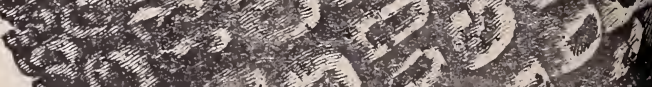
Greatest of Corns. 